Supporting Information for

\title{
Overcoming scope limitations in cross-coupling of diazo nu- cleophiles by manipulating catalyst speciation and using flow diazo generation
}

\author{
Ryan J. Sullivan, Garrett P. R. Freure, Stephen G. Newman* \\ Centre for Catalysis Research and Innovation, Department of Chemistry and Biomolecular \\ Sciences, University of Ottawa, 10 Marie-Curie, Ottawa, Ontario, Canada, K1N 6N5 \\ *E-mail: stephen.newman@uottawa.ca.
}

\section{Contents}

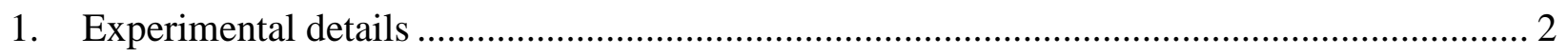

2. Additional flow reactor and equipment details..................................................... 21

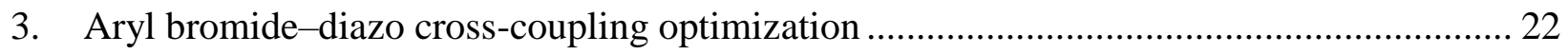

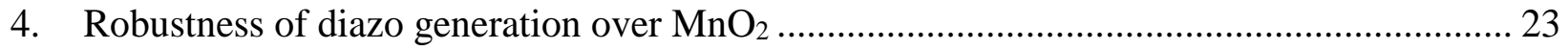

5. Calculation of TOF from computed energy profiles ................................................ 25

6. Additional computational results not included in the manuscript .................................... 25

7. Characterization data of hydrazones, diazo compounds and palladium precatalysts ........... 27

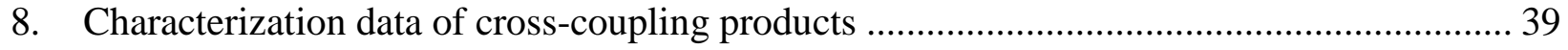

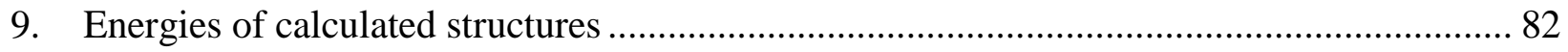

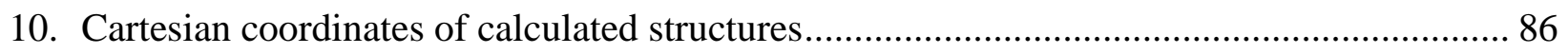

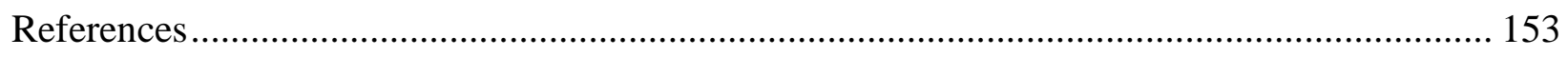




\section{Experimental details}

General Methods. NMR spectra were collected on a Bruker Avance $400 \mathrm{MHz}$ spectrometer. ${ }^{1} \mathrm{H}$ and ${ }^{13} \mathrm{C}$ were referenced to residual solvent signals and ${ }^{31} \mathrm{P}$ and ${ }^{19} \mathrm{~F}$ were reference externally to $85 \% \mathrm{H}_{3} \mathrm{PO}_{4}$ and neat $\mathrm{CF}_{3} \mathrm{COOH}$ respectively. IR spectra of compounds were obtained using a Nicolet6700 FT-IR spectrometer with a diamond ATR crystal (ThermoScientific). IR spectra of diazo compounds were monitored using a Metler Toledo FlowIR equirped with a silicon wafer ATR element. Accurate mass data (EI) was obtained from an Agilent 5977A GC/MSD using MassWorks 4.0 from CERNO bioscience. ${ }^{1} \mathrm{MnO}_{2}, \geq 90 \%$ activated, was obtained from Fluka (product number 63548), all other chemicals were obtained from commercial sources and used as received. Toluene was degassed with Ar and passed through a PureSolv solvent purification system before use. Cross-coupling reactions were carried out in oven-dried glassware under an $\mathrm{Ar}$ atmosphere. 5\% $\mathrm{AgNO}_{3}$ impregnated silica gel was prepared by adding a solution of $\mathrm{AgNO}_{3}(7.5$ g) in $\mathrm{MeCN}(100 \mathrm{~mL})$ to a slurry of silica gel $(150 \mathrm{~g})$ in $\mathrm{MeCN}(500 \mathrm{~mL})$ and evaporating the solvent. Ethyl 2-diazopropanoate, ${ }^{2}$ and $\mathrm{Pd}(\mathrm{XPhos})\left(\right.$ allyl) $\mathrm{Cl}^{3}$ were prepared by literature procedures and their characterization data were in agreement with that reported by the authors.

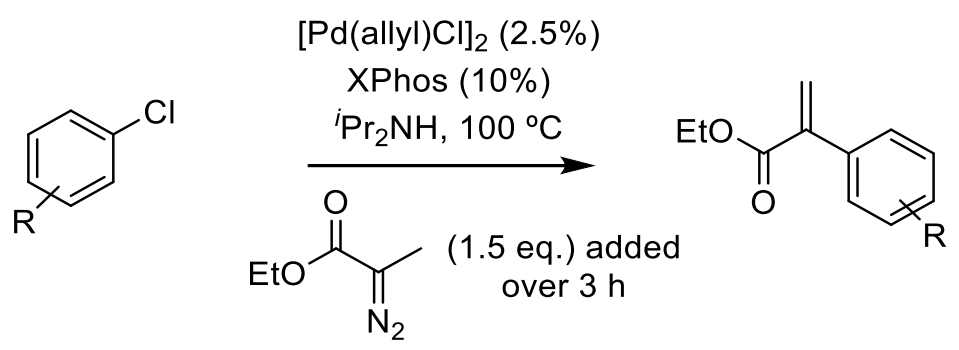

General Procedure for Ethyl 2-Diazopropanoate-Aryl Chloride Cross-Coupling. $\left[\mathrm{Pd}(\text { allyl) } \mathrm{Cl}]_{2}(1.8 \mathrm{mg}, 5 \mu \mathrm{mol}), \mathrm{XPhos}(9.5 \mathrm{mg}, 20 \mu \mathrm{mol})\right.$ and aryl chloride (if solid; $0.2 \mathrm{mmol}$ ) were placed in an $8 \mathrm{~mL}$ screw top tube and flushed with Ar. Toluene $(1 \mathrm{~mL})$ and aryl chloride (if liquid; $0.2 \mathrm{mmol}$ ) were added and the solution stirred at room temperature for $10 \mathrm{~min}$. ${ }^{i} \mathrm{Pr}_{2} \mathrm{NH}$ (85 $\mu \mathrm{L}, 0.6 \mathrm{mmol}$ ) was added and the solution stirred an additional $3 \mathrm{~min}$ at room temperature. Separately a solution of ethyl 2-diazopropanoate $(42 \mu \mathrm{L}, 0.36 \mathrm{mmol})$ in toluene $(1.2 \mathrm{~mL})$ was prepared and taken up into a $1 \mathrm{~mL}$ plastic HSW syringe and placed on a NewEra NE-300 syringe pump. The aryl chloride solution was placed in a $100{ }^{\circ} \mathrm{C}$ oil bath and stirred for 3 min followed by addition of ethyl 2-diazopropanoate solution at a rate of $333 \mu \mathrm{L} / \mathrm{h}$ for $3 \mathrm{~h}(1 \mathrm{~mL}, 0.3 \mathrm{mmol}$ diazo). The reaction was stirred an additional 15 min after addition was complete then cooled to room temperature and filtered through silica eluting with acetonitrile and purified by flash column chromatography immediately. 
<smiles>C=C(C(=O)OCC)c1ccc(C#N)cc1</smiles>

Ethyl 2-(4-cyanophenyl)acrylate (1a). Prepared by the general procedure and purified on silica eluting with $10 \%$ EtOAc in hexanes. Yield $31.1 \mathrm{mg}(77 \%)$ colourless oil. Characterization data were in agreement with the literature. ${ }^{4}{ }^{1} \mathrm{H} \mathrm{NMR}\left(400 \mathrm{MHz}, \mathrm{CDCl}_{3}\right) 7.65(\mathrm{~d}, J=8.7 \mathrm{~Hz}, 2 \mathrm{H}), 7.53$ $(\mathrm{d}, J=8.1 \mathrm{~Hz}, 2 \mathrm{H}), 6.49(\mathrm{~d}, J=0.8 \mathrm{~Hz}, 1 \mathrm{H}), 5.97(\mathrm{~d}, J=0.9 \mathrm{H}, 1 \mathrm{H}), 4.30(\mathrm{q}, J=7.1 \mathrm{~Hz}, 2 \mathrm{H}), 1.35$ $(\mathrm{t}, J=7.1 \mathrm{~Hz}, 3 \mathrm{H}) .{ }^{13} \mathrm{C}\left\{{ }^{1} \mathrm{H}\right\} \mathrm{NMR}\left(100 \mathrm{MHz}, \mathrm{CDCl}_{3}\right)$ 165.8, 141.4, 140.3, 132.0, 129.2, 129.0, $118.8,112.0,61.6,14.3$.<smiles>C=C(C(=O)OCC)c1ccc(C(C)=O)cc1</smiles>

Ethyl 2-(4-acetylphenyl)acrylate (1b). Prepared by the general procedure and purified on silica eluting with $3.5 \rightarrow 10 \%$ EtOAc in hexanes. Yield $36.5 \mathrm{mg}(84 \%)$ pale yellow oil. Characterization date were in agreement with the literature. ${ }^{4} \mathrm{H} \mathrm{NMR}\left(400 \mathrm{MHz}, \mathrm{CDCl}_{3}\right) 7.94(\mathrm{~d}, J=8.5 \mathrm{~Hz}, 2 \mathrm{H})$, $7.52(\mathrm{~d}, J=8.5 \mathrm{~Hz}, 2 \mathrm{H}), 6.45(\mathrm{~d}, J=1.0 \mathrm{~Hz}, 1 \mathrm{H}), 5.97(\mathrm{~d}, J=1.0 \mathrm{~Hz}, 1 \mathrm{H}), 4.30(\mathrm{q}, J=7.2 \mathrm{~Hz}$, 2H), $2.61(\mathrm{~s}, 3 \mathrm{H}), 1.34(\mathrm{t}, J=7.2 \mathrm{~Hz}, 3 \mathrm{H}) .{ }^{13} \mathrm{C}\left\{{ }^{1} \mathrm{H}\right\} \mathrm{NMR}\left(100 \mathrm{MHz}, \mathrm{CDCl}_{3}\right)$ 197.8, 166.3, 141.5, $140.9,136.7,128.7,128.3,128.2,61.5,26.8,14.3$.<smiles>C=C(C(=O)OCC)c1ccc(C=O)cc1</smiles>

Ethyl 2-(4-formylphenyl)acrylate (1c). Prepared by the general procedure and purified on silica eluting with $3.5 \%$ EtOAc in hexanes. Yield $26.5 \mathrm{mg}(84 \%)$ pale yellow oil. ${ }^{1} \mathrm{H}$ NMR (400 MHz, $\left.\mathrm{CDCl}_{3}\right) 10.03(\mathrm{~s}, 1 \mathrm{H}), 7.87(\mathrm{~d}, J=8.4 \mathrm{~Hz}, 2 \mathrm{H}), 7.59(\mathrm{~d}, J=8.2 \mathrm{~Hz}, 2 \mathrm{H}), 6.48(\mathrm{~d}, J=0.8 \mathrm{~Hz}, 1 \mathrm{H})$, $5.99(\mathrm{~d}, J=0.8 \mathrm{~Hz}, 1 \mathrm{H}), 4.30(\mathrm{q}, J=7.1 \mathrm{~Hz}, 2 \mathrm{H}), 1.34(\mathrm{t}, J=7.2 \mathrm{~Hz}, 3 \mathrm{H}) .{ }^{13} \mathrm{C}\left\{{ }^{1} \mathrm{H}\right\} \mathrm{NMR}(100$ $\left.\mathrm{MHz}, \mathrm{CDCl}_{3}\right)$ 192.0, 166.1, 142.9, 140.8, 136.0, 129.6, 129.2, 128.6, 61.6, 14.3. IR v(C=O) 1698, $1725 \mathrm{~cm}^{-1}$. HRMS calcd for $\mathrm{C}_{12} \mathrm{H}_{12} \mathrm{O}_{3}$ 204.0786; found 204.0781, spectral accuracy $96.7 \%$.<smiles>C=C(C(=O)OCC)c1ccc(/C=C/C(=O)c2ccccc2)cc1</smiles>

Ethyl 2-(chalcone-4-yl)acrylate (1d). Prepared by the general procedure and purified on silica eluting with $3.5 \rightarrow 10 \%$ EtOAc in hexanes. Yield $55.8 \mathrm{mg}(91 \%)$ pale yellow oil. ${ }^{1} \mathrm{H}$ NMR (400 $\left.\mathrm{MHz} \mathrm{CDCl}_{3}\right) 8.02(\mathrm{~d}, J=8.6 \mathrm{~Hz}, 2 \mathrm{H}), 7.82(\mathrm{~d}, J=15.7 \mathrm{~Hz}, 1 \mathrm{H}), 7.57(\mathrm{~m}, 8 \mathrm{H}), 6.41(\mathrm{~d}, J=0.8$ $\mathrm{Hz}, 1 \mathrm{H}), 5.96(\mathrm{~d}, J=0.9 \mathrm{~Hz}, 1 \mathrm{H}), 4.31(\mathrm{q}, J=7.1 \mathrm{~Hz}, 2 \mathrm{H}), 1.33(\mathrm{t}, J=7.1 \mathrm{~Hz}, 3 \mathrm{H}) .{ }^{13} \mathrm{C}\left\{{ }^{1} \mathrm{H}\right\} \mathrm{NMR}$ 
$\left(100 \mathrm{MHz}, \mathrm{CDCl}_{3}\right)$ 190.6, 166.5, 144.3, 141.0, 139.0, 138.3, 134.8, 133.0, 129.0, 128.8, 128.6, 128.3, 127.3, 122.5, 61.4, 14.3. IR $v(\mathrm{C}=\mathrm{O}) 1661,1721 \mathrm{~cm}^{-1}$. HRMS calcd for $\mathrm{C}_{20} \mathrm{H}_{18} \mathrm{O}_{3} 306.1256$; found 306.1250 , spectral accuracy $98.1 \%$.<smiles>C=C(C(=O)OCC)c1ccccc1</smiles>

Ethyl 2-phenylacrylate (1e). Prepared by the general procedure and purified on silica eluting with 5\% EtOAc in hexanes. Yield $26.6 \mathrm{mg}(75 \%)$ colourless oil. Characterization data were in agreement with the literature. ${ }^{5}{ }^{1} \mathrm{H}$ NMR $\left(400 \mathrm{MHz}, \mathrm{CDCl}_{3}\right) 7.43(\mathrm{~m} .2 \mathrm{H}), 7.35(\mathrm{~m}, 3 \mathrm{H}), 6.36(\mathrm{~d}, J$ $=1.3 \mathrm{~Hz}, 1 \mathrm{H}), 5.89(\mathrm{~d}, J=1.3 \mathrm{~Hz}, 1 \mathrm{H}), 4.30(\mathrm{q}, J=7.1 \mathrm{~Hz}, 2 \mathrm{H}), 1.34(\mathrm{t}, J=7.1 \mathrm{~Hz}, 3 \mathrm{H}) .{ }^{13} \mathrm{C}\left\{{ }^{1} \mathrm{H}\right\}$ NMR (100 MHz, $\left.\mathrm{CDCl}_{3}\right)$ 166.9, 141.7, 136.9, 128.4, 128.24, 128.21, 126.6, 61.2, 14.3.<smiles>C=Cc1ccc(C(=C)C(=O)OCC)cc1</smiles>

Ethyl 2-(4-styenyl)acyrlate (1f). Prepared by the general procedure and purified on silica eluting with $3.5 \%$ EtOAc in hexanes. Yield $29.6 \mathrm{mg}(73 \%)$ pale yellow oil. ${ }^{1} \mathrm{H}$ NMR $\left(400 \mathrm{MHz}, \mathrm{CDCl}_{3}\right)$ $7.40(\mathrm{~s}, 4 \mathrm{H}), 6.73(\mathrm{dd}, J=17.6,10.9 \mathrm{~Hz}, 1 \mathrm{H}), 6.33(\mathrm{~d}, J=1.2 \mathrm{~Hz}, 1 \mathrm{H}), 5.90(\mathrm{~d}, J=1.2 \mathrm{~Hz}, 1 \mathrm{H})$, $5.77(\mathrm{~d}, J=17.6 \mathrm{~Hz}, 1 \mathrm{H}), 5.27(\mathrm{~d}, J=11.0 \mathrm{~Hz}, 1 \mathrm{H}), 4.30(\mathrm{q}, J=7.1 \mathrm{~Hz}, 2 \mathrm{H}), 1.34(\mathrm{t}, J=7.2 \mathrm{~Hz}$, $3 \mathrm{H}) .{ }^{13} \mathrm{C}\left\{{ }^{1} \mathrm{H}\right\}$ NMR $\left(100 \mathrm{MHz}, \mathrm{CDCl}_{3}\right) 166.9,141.3,137.6,136.5,136.3,128.6,126.3,126.1$, 114.4, 61.3, 14.4. IR $v(\mathrm{C}=\mathrm{O}) 1719 \mathrm{~cm}^{-1}$. HRMS calcd for $\mathrm{C}_{13} \mathrm{H}_{14} \mathrm{O}_{2}$ 202.0994; found 202.0998, spectral accuracy $99.4 \%$.<smiles>C=C(C(=O)OCC)c1ccc(C)cc1</smiles>

Ethyl 2-(4-methylthiophenyl)acrylate (1g). Prepared by the general procedure and purified on silica eluting with 3.5\% EtOAc in hexanes. Yield $27.3 \mathrm{mg}(62 \%)$ pale yellow oil. Characterization data were in agreement with the literature. ${ }^{6} \mathrm{H}$ NMR $\left(400 \mathrm{MHz}, \mathrm{CDCl}_{3}\right) 7.36(\mathrm{~d}, J=8.4 \mathrm{~Hz}, 2 \mathrm{H})$, $7.23(\mathrm{~d}, J=8.4 \mathrm{~Hz}, 2 \mathrm{H}), 6.31(\mathrm{~d}, J=1.0 \mathrm{~Hz}, 1 \mathrm{H}), 5.87(\mathrm{~d}, J=1.0 \mathrm{~Hz}, 1 \mathrm{H}), 4.29(\mathrm{q}, J=7.1 \mathrm{~Hz}$, 2H), $2.49(\mathrm{~s}, 3 \mathrm{H}), 1.34(\mathrm{t}, J=7.1 \mathrm{~Hz}, 3 \mathrm{H}) .{ }^{13} \mathrm{C}\left\{{ }^{1} \mathrm{H}\right\}$ NMR (100 MHz, $\left.\mathrm{CDCl}_{3}\right)$ 166.9, 141.0, 138.8, $133.6,128.8,126.2,126.0,61.3,15.8,14.3$.<smiles>C=C(C(=O)OCC)c1ccc(OC)cc1</smiles>

Ethyl 2-(4-methoxyphenyl)acrylate (1h). Prepared by the general procedure with $2 \times$ catalyst load $\left(10 \mu \mathrm{mol}[\mathrm{Pd}(\mathrm{allyl}) \mathrm{Cl}]_{2}, 40 \mu \mathrm{mol} \mathrm{XPhos}\right)$ and purified on silica eluting with $0.5 \rightarrow 10 \%$ EtOAc in hexanes. Yield $27.4 \mathrm{mg}(66 \%)$ pale yellow oil. Characterization data were in agreement with the 
literature. ${ }^{7}{ }^{1} \mathrm{H}$ NMR (400 MHz, $\left.\mathrm{CDCl}_{3}\right) 7.37(\mathrm{~d}, J=8.8 \mathrm{~Hz}, 2 \mathrm{H}), 6.88(\mathrm{~d}, J=8.8 \mathrm{~Hz}, 2 \mathrm{H}), 6.25(\mathrm{~d}$, $J=1.0 \mathrm{~Hz}, 1 \mathrm{H}), 5.82(\mathrm{~d}, J=1.1 \mathrm{~Hz}, 1 \mathrm{H}), 4.29(\mathrm{q}, J=7.1 \mathrm{~Hz}, 2 \mathrm{H}), 3.82(\mathrm{~s}, 3 \mathrm{H}), 1.33(\mathrm{t}, J=7.2$ $\mathrm{Hz}, 3 \mathrm{H}) .{ }^{13} \mathrm{C}\left\{{ }^{1} \mathrm{H}\right\} \mathrm{NMR}\left(100 \mathrm{MHz}, \mathrm{CDCl}_{3}\right) 167.3,159.7,141.1,129.6,129.4,125.1,113.7,61.2$, $55.4,14.4$.<smiles>C=C(C(=O)OCC)c1c(C)cccc1C</smiles>

Ethyl 2-(2,6-dimethylphenyl)acrylate (1i). Prepared by the general procedure and purified on silica eluting with $3.5 \%$ EtOAc in hexanes. Yield $21.2 \mathrm{mg}(52 \%)$ pale yellow oil. ${ }^{1} \mathrm{H} \mathrm{NMR}(400 \mathrm{MHz}$, $\left.\mathrm{CDCl}_{3}\right) 7.13(\mathrm{dd}, J=8.3,6.7 \mathrm{~Hz}, 1 \mathrm{H}), 7.05(\mathrm{~d}, J=7.6 \mathrm{~Hz}, 2 \mathrm{H}), 6.65(\mathrm{~d}, J=1.8 \mathrm{~Hz}, 1 \mathrm{H}), 5.61(\mathrm{~d}$, $J=1.8 \mathrm{~Hz}, 1 \mathrm{H}), 4.23(\mathrm{q}, J=7.1 \mathrm{~Hz}, 2 \mathrm{H}), 2.18(\mathrm{~s}, 6 \mathrm{H}), 1.26(\mathrm{t}, J=7.1 \mathrm{~Hz}, 3 \mathrm{H}) .{ }^{13} \mathrm{C}\left\{{ }^{1} \mathrm{H}\right\} \mathrm{NMR}$ $\left(100 \mathrm{MHz}, \mathrm{CDCl}_{3}\right) 166.6,140.3,137.0,136.2,129.1,127.6,127.3,61.0,20.4,14.3 . \mathrm{IR} v(\mathrm{C}=\mathrm{O})$ $1716 \mathrm{~cm}^{-1}$. HRMS calcd for $\mathrm{C}_{13} \mathrm{H}_{16} \mathrm{O}_{2} 204.1150$; found 204.1145 , spectral accuracy $99.0 \%$.<smiles>C=C(C(=O)OCC)c1cccc2[nH]ccc12</smiles>

Ethyl 2-(indol-4-yl)acrylate (1j). Prepared by the general procedure and purified on silica eluting with 4:1 hexanes:EtOAc. Yield $31.6 \mathrm{mg}(73 \%)$ pale yellow oil. ${ }^{1} \mathrm{H}$ NMR (400 $\left.\mathrm{MHz}, \mathrm{CDCl}_{3}\right) 8.21$ (br s, 1H), $7.38(\mathrm{~d}, J=8.1 \mathrm{~Hz}, 1 \mathrm{H}), 7.20(\mathrm{~m}, 2 \mathrm{H}), 7.10(\mathrm{~d}, J=7.3 \mathrm{~Hz}, 1 \mathrm{H}), 6.53(\mathrm{~d}, J=1.6 \mathrm{~Hz}$, $1 \mathrm{H}), 6.47(\mathrm{~m}, 1 \mathrm{H}), 5.99(\mathrm{~d}, J=1.7 \mathrm{~Hz}, 1 \mathrm{H}), 4.29(\mathrm{q}, J=7.1 \mathrm{~Hz}, 2 \mathrm{H}), 1.30(\mathrm{t}, J=7.1 \mathrm{~Hz}, 3 \mathrm{H})$. ${ }^{13} \mathrm{C}\left\{{ }^{1} \mathrm{H}\right\}$ NMR $\left(100 \mathrm{MHz}, \mathrm{CDCl}_{3}\right)$ 167.5, 141.1, 136.0, 129.7, 127.6, 126.8, 124.4, 121.9, 120.5, 111.2, 102.1, 61.2, 14.4. IR $v(\mathrm{C}=\mathrm{O}) 1694 \mathrm{~cm}^{-1}$. HRMS calcd for $\mathrm{C}_{13} \mathrm{H}_{13} \mathrm{NO}_{2}$ 215.0946; found 215.0941, spectral accuracy $99.1 \%$.<smiles>C=C(C(=O)OCC)c1ccc2c(c1)OCO2</smiles>

Ethyl 2-(1,3-benzodioxol-5-yl)acrylate (1k). Prepared by the general procedure and purified on silica eluting with $2 \rightarrow 5 \%$ EtOAc in hexanes. Yield $22.0 \mathrm{mg}(50 \%)$ orange oil. ${ }^{1} \mathrm{H} \mathrm{NMR}(400 \mathrm{MHz}$, $\left.\mathrm{CDCl}_{3}\right) 6.90(\mathrm{~m}, 2 \mathrm{H}), 6.79(\mathrm{~d}, J=8.0 \mathrm{~Hz}, 1 \mathrm{H}), 6.25(\mathrm{~d}, J=1.3 \mathrm{~Hz}, 1 \mathrm{H}), 5.97(\mathrm{~s}, 2 \mathrm{H}), 5.81(\mathrm{~d}, J=$ $1.2 \mathrm{~Hz}, 1 \mathrm{H}), 4.28(\mathrm{q}, J=7.2 \mathrm{~Hz}, 2 \mathrm{H}), 1.33(\mathrm{t}, J=7.2 \mathrm{~Hz}, 3 \mathrm{H}) .{ }^{13} \mathrm{C}\left\{{ }^{1} \mathrm{H}\right\} \mathrm{NMR}\left(100 \mathrm{MHz}, \mathrm{CDCl}_{3}\right)$ 167.0, 147.7, 147.5, 141.2, 130.9, 125.6, 122.2, 109.0, 108.1, 101.3, 61.3, 14.4. IR v(C=O) 1714 $\mathrm{cm}^{-1}$. HRMS calcd for $\mathrm{C}_{12} \mathrm{H}_{12} \mathrm{O}_{4} 220.0736$; found 220.0789, spectral accuracy $99.5 \%$.<smiles>C=C(C(=O)OCC)c1ccccc1</smiles> 
Ethyl 2-phenylacrylate (1e prepared from $\mathrm{PhBr})$. $\mathrm{Pd}(\mathrm{XPhos})($ allyl)Cl $(4.6 \mathrm{mg}, 7 \mu \mathrm{mol})$ and XPhos $(3.3 \mathrm{mg}, 7 \mu \mathrm{mol})$ were placed in a $25 \mathrm{~mL}$ round bottom flask and flushed with Ar. Toluene $(1 \mathrm{~mL}),{ }^{i} \mathrm{Pr}_{2} \mathrm{NH}(28 \mu \mathrm{L}, 0.2 \mathrm{mmol})$ and bromobenzene $(21 \mu \mathrm{L}, 0.2 \mathrm{mmol})$ were added. Separately a solution of ethyl 2-diazopropanoate $(42 \mu \mathrm{L}, 0.36 \mathrm{mmol})$ in toluene $(1.2 \mathrm{~mL})$ was prepared and taken up into a $1 \mathrm{~mL}$ plastic HSW syringe and placed on a NewEra NE-300 syringe pump. The aryl chloride solution was placed in an $80^{\circ} \mathrm{C}$ oil bath and stirred for $\sim 3$ min then addition of ethyl 2-diazopropoanate solution at a rate of $4 \mathrm{~mL} / \mathrm{h}$ for $15 \mathrm{~min}(1 \mathrm{~mL}, 0.3 \mathrm{mmol}$ diazo). The reaction was stirred an additional $15 \mathrm{~min}$ after addition was complete then cooled to room temperature and filtered through silica eluting with 2:1 EtOAc:hexanes and purified immediately by flash column chromatography on silica eluting with 3.5\% EtOAc in hexanes. Yield $27.3 \mathrm{mg}(77 \%)$ colourless oil. Characterization data were in agreement with the literature. ${ }^{5}$

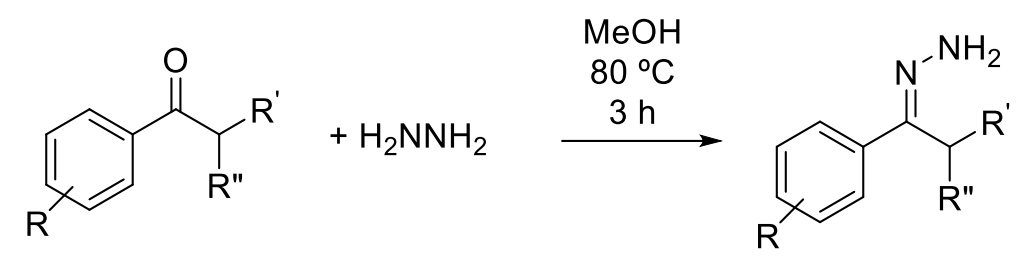

Hydrazone Synthesis. Hydrazones were prepared by the general procedure reported by Poh et. al. with modification to the isolation and purification protocols. ${ }^{8}$

Isolation procedure A. The reaction mixture was partitioned between water $(25 \mathrm{~mL})$ and DCM $(25 \mathrm{~mL})$. The aqueous layer was extracted with an additional $2 \times 10 \mathrm{~mL}$ DCM and the combined organic extracts were dried over $\mathrm{Na}_{2} \mathrm{SO}_{4}$ and the solvent removed in vacuo. The crude hydrazone was then recrystallized from 20:1 hexanes:EtOAc.

Isolation procedure B. The reaction mixture was diluted with water $(25 \mathrm{~mL})$ and the crystallized product was collected by filtration and washed with water $(5 \mathrm{~mL})$. The filter cake was taken up in DCM $(25 \mathrm{~mL})$, dried over $\mathrm{Na}_{2} \mathrm{SO}_{4}$ and the solvent removed in vacuo.<smiles>C/C(=N\N)c1ccccc1</smiles>

Acetophenone hydrazone. Prepared by the literature procedure using isolation procedure A without recrystallization. Yield $1.24 \mathrm{~g}(93 \%)$ colourless oil, stored frozen at $-20{ }^{\circ} \mathrm{C}$. Characterization data were in agreement with the literature. ${ }^{8} \mathrm{H} \mathrm{NMR}\left(400 \mathrm{MHz}, \mathrm{CDCl}_{3}\right) 7.65(\mathrm{~m}, 2 \mathrm{H}), 7.32(\mathrm{~m}, 3 \mathrm{H})$, 5.37 (br s, 2H), 2.11 (s, 3H). ${ }^{13} \mathrm{C}\left\{{ }^{1} \mathrm{H}\right\} \mathrm{NMR}\left(100 \mathrm{MHz}, \mathrm{CDCl}_{3}\right)$ 147.2, 139.4, 128.2, 128.0, 125.4, 11.6 . 
<smiles>C/C(=N\N)c1ccc2ccccc2c1</smiles>

2-Acetonaphthone hydrazone. Prepared by the literature procedure using isolation procedure B. Yield $1.59 \mathrm{~g}(87 \%)$ white solid. Characterization data were in agreement with the literature. ${ }^{9}{ }^{1} \mathrm{H}$ NMR (400 MHz, $\left.\mathrm{CDCl}_{3}\right) 7.97$ (m, 2H), $7.82(\mathrm{~m}, 3 \mathrm{H}), 7.47$ (m, 2H), 5.44 (br s, 2H), 2.25 (s, 3H). ${ }^{13} \mathrm{C}\left\{{ }^{1} \mathrm{H}\right\}$ NMR $\left(100 \mathrm{MHz}, \mathrm{CDCl}_{3}\right)$ 147.2, 139.8, 133.36, 133.28, 128.4, 128.0, 127.7, 126.23, 126.17, 124.7, 123.6, 11.5.<smiles>COC(=O)c1ccc(/C(C)=N/N)cc1</smiles>

Methyl 4-acetylbenzoate hydrazone. Prepared by the literature procedure using isolation procedure B. Yield $0.96 \mathrm{~g}(50 \%)$ white solid. ${ }^{1} \mathrm{H} \mathrm{NMR}\left(400 \mathrm{MHz}, \mathrm{CDCl}_{3}\right) 8.01(\mathrm{~d}, J=8.8 \mathrm{~Hz}, 2 \mathrm{H}), 7.71$ (d, $J=8.8 \mathrm{~Hz}, 2 \mathrm{H}), 5.50($ br s, $2 \mathrm{H}), 3.91(\mathrm{~s}, 3 \mathrm{H}), 2.14(\mathrm{~s}, 3 \mathrm{H}) \cdot{ }^{13} \mathrm{C}\left\{{ }^{1} \mathrm{H}\right\} \mathrm{NMR}\left(100 \mathrm{MHz}, \mathrm{CDCl}_{3}\right)$ 167.1, 145.7, 143.6, 129.7, 129.4, 125.4, 52.2, 11.5. HRMS calcd for $\mathrm{C}_{10} \mathrm{H}_{12} \mathrm{~N}_{2} \mathrm{O}_{2}$ 192.0899; found 192.0901, spectral accuracy $98.8 \%$.<smiles>COc1ccc(/C(C)=N/N)cc1</smiles>

4'-Methoxyacetophenone hydrazone. Prepared by the literature procedure using isolation procedure B. Yield $1.23 \mathrm{~g}(75 \%)$ white solid. Characterization data were in agreement with the literature. ${ }^{10}{ }^{1} \mathrm{H}$ NMR $\left(400 \mathrm{MHz}, \mathrm{CDCl}_{3}\right) 7.59(\mathrm{~d}, J=9.0 \mathrm{~Hz}, 2 \mathrm{H}), 6.88(\mathrm{~d}, J=9.0 \mathrm{~Hz}, 2 \mathrm{H}), 5.25$ (br s, 2H), 3.92 (s, 3H), 2.12 (s, 3H). ${ }^{13} \mathrm{C}\left\{{ }^{1} \mathrm{H}\right\}$ NMR (100 MHz, $\left.\mathrm{CDCl}_{3}\right)$ 159.8, 147.6, 132.3, 126.9, $113.8,55.4,11.8$.<smiles>C/C(=N\N)c1ccc(C)cc1C</smiles>

2',4'-Dimethylacetophenone hydrazone. Prepared by the literature procedure using isolation procedure A. Yield $0.92 \mathrm{~g}(56 \%)$ white solid. ${ }^{1} \mathrm{H} \mathrm{NMR}\left(400 \mathrm{MHz}, \mathrm{CDCl}_{3}\right) 7.11$ (d, J=7.7 Hz, 1H), $6.98(\mathrm{~m}, 2 \mathrm{H}), 5.24$ (br s, 2H), $2.31(\mathrm{~s}, 6 \mathrm{H}), 2.09$ (s, 3H). ${ }^{13} \mathrm{C}\left\{{ }^{1} \mathrm{H}\right\} \mathrm{NMR}\left(100 \mathrm{MHz}, \mathrm{CDCl}_{3}\right)$ $150.2,138.0,137.5,135.3,131.5,128.0,126.5,21.2,20.3,15.7$. HRMS calcd for $\mathrm{C}_{10} \mathrm{H}_{14} \mathrm{~N}_{2}$ 162.1157; found 162.1175, spectral accuracy $97.4 \%$. 
<smiles>C/C(=N\N)c1cccs1</smiles>

2-Acetylthiophene hydrazone. Prepared by the literature procedure using isolation procedure A. Yield $0.95 \mathrm{~g}(68 \%)$ white solid. Characterization data in agreement with the literature. ${ }^{11}{ }^{1} \mathrm{H} \mathrm{NMR}$ $\left(400 \mathrm{MHz}, \mathrm{CDCl}_{3}\right) 7.20(\mathrm{~d}, J=5.1 \mathrm{~Hz}, 1 \mathrm{H}), 7.11(\mathrm{~d}, J=3.6 \mathrm{~Hz}, 1 \mathrm{H}), 6.98(\mathrm{dd}, J=5.0,3.8 \mathrm{~Hz}$, 1H), 5.26 (br s, 2H), 2.14 (s, 3H). ${ }^{13} \mathrm{C}\left\{{ }^{1} \mathrm{H}\right\} \mathrm{NMR}\left(100 \mathrm{MHz}, \mathrm{CDCl}_{3}\right)$ 145.0, 143.9, 127.1, 126.0, 124.1, 12.1 .<smiles>CC(C)/C(=N\N)c1ccccc1</smiles>

Isobutyrophenone hydrazone. Prepared by the literature procedure with the modification of $6 \mathrm{~h}$ reaction time at $80{ }^{\circ} \mathrm{C}$ and using isolation protocol $\mathrm{A}$ with $\mathrm{Et}_{2} \mathrm{O}$ in the place of $\mathrm{DCM}$ and no recrystallization. Yield $1.49 \mathrm{~g}(90 \%)$ colourless oil, stored frozen at $-20{ }^{\circ} \mathrm{C}$. Characterization data were in agreement with the literature. ${ }^{12}{ }^{1} \mathrm{H} \mathrm{NMR}\left(400 \mathrm{MHz}, \mathrm{CDCl}_{3}\right) 7.45(\mathrm{t}, J=7.2 \mathrm{~Hz}, 2 \mathrm{H}), 7.36$ (t, $J=7.4 \mathrm{~Hz}, 1 \mathrm{H}), 7.17$ (m, 2H), 4.93 (br s, 2H), 2.72 (heptet, $J=6.9 \mathrm{~Hz}, 1 \mathrm{H}), 1.08$ (d, $J=6.9$ $\mathrm{Hz}, 6 \mathrm{H}) .{ }^{13} \mathrm{C}\left\{{ }^{1} \mathrm{H}\right\} \mathrm{NMR}\left(100 \mathrm{MHz}, \mathrm{CDCl}_{3}\right)$ 157.5, 134.4, 129.1, 128.5, 127.9, 36.1, 20.4.<smiles>NN=C(c1ccccc1)C1CCCCC1</smiles>

Cyclohexyl phenyl ketone hydrazone. Prepared by the literature procedure using isolation procedure A. Yield $0.79 \mathrm{~g}(39 \%)$ white solid. ${ }^{1} \mathrm{H} \mathrm{NMR}\left(400 \mathrm{MHz}, \mathrm{CDCl}_{3}\right) 7.46(\mathrm{t}, J=7.1 \mathrm{~Hz}, 2 \mathrm{H})$, $7.37(\mathrm{t}, J=7.4 \mathrm{~Hz}, 1 \mathrm{H}), 7.17$ (d, $J=8.3 \mathrm{~Hz}, 2 \mathrm{H}), 4.92$ (br s, 2H), 2.37 (m, 1H), 1.79 (m, 4H), 1.64 $(\mathrm{m}, 1 \mathrm{H}), 1.25(\mathrm{~m}, 4 \mathrm{H}), 1.14(\mathrm{~m}, 1 \mathrm{H}) .{ }^{13} \mathrm{C}\left\{{ }^{1} \mathrm{H}\right\} \mathrm{NMR}\left(100 \mathrm{MHz}, \mathrm{CDCl}_{3}\right)$ 157.2, 134.7, 129.2, 128.5, 127.8, 46.0, 30.8, 26.4, 26.3. HRMS calcd for $\mathrm{C}_{13} \mathrm{H}_{18} \mathrm{~N}_{2}$ 202.1470; found 202.1508, spectral accuracy $90.8 \%$.<smiles>CC/C(=N\N)c1cccc(OC)c1</smiles>

3'-Methoxyprophionone hydrazone. Prepared by the literature procedure using isolation procedure A with $\mathrm{Et}_{2} \mathrm{O}$ in the place of DCM and no recrystallization. Yield $1.62 \mathrm{~g}(90 \%)$ pale yellow oil, stored at $-20{ }^{\circ} \mathrm{C}$. Characterization data were in agreement with the literature. ${ }^{13}{ }^{1} \mathrm{H} \mathrm{NMR}(400 \mathrm{MHz}$, $\left.\mathrm{CDCl}_{3}\right) 7.25(\mathrm{~m}, 2 \mathrm{H}), 7.20(\mathrm{dt}, J=8.0,1.3,1 \mathrm{H}), 6.85(\mathrm{ddd}, J=8.0,2.6,1.2 \mathrm{~Hz}, 1 \mathrm{H}), 5.42$ (br s, $2 \mathrm{H}), 3.83(\mathrm{~s}, 3 \mathrm{H}), 2.62(\mathrm{q}, J=7.8 \mathrm{~Hz}, 2 \mathrm{H}), 1.17(\mathrm{t}, J=7.7 \mathrm{~Hz}, 3 \mathrm{H}) .{ }^{13} \mathrm{C}\left\{{ }^{1} \mathrm{H}\right\} \mathrm{NMR}(100 \mathrm{MHz}$, $\left.\mathrm{CDCl}_{3}\right)$ 159.8, 151.6, 139.9, 129.4, 118.2, 114.2, 110.8, 55.4, 18.7, 9.9. 
<smiles>N/N=C1\CCOc2ccccc21</smiles>

4-Chromanone hydrazone. Prepared by the literature procedure using isolation procedure A. Yield $1.60 \mathrm{~g}(98 \%)$ yellow solid. Characterization date were in agreement with the literature. ${ }^{14}{ }^{1} \mathrm{H} \mathrm{NMR}$ $\left(400 \mathrm{MHz}, \mathrm{CDCl}_{3}\right) 7.90(\mathrm{dd}, J=7.9,1.6 \mathrm{~Hz}, 1 \mathrm{H}), 7.19(\mathrm{td}, J=7.8,1.7,1 \mathrm{H}), 6.95(\mathrm{td}, J=7.6,1.2$ $\mathrm{Hz}, 1 \mathrm{H}), 6.88$ (dd, $J=8.2,0.9 \mathrm{~Hz}, 1 \mathrm{H}), 5.28(\mathrm{br} \mathrm{s}, 2 \mathrm{H}), 4.28(\mathrm{t}, J=6.1 \mathrm{~Hz}, 2 \mathrm{H}), 2.67$ (t, $J=6.2$ $\mathrm{Hz}, 2 \mathrm{H}) .{ }^{13} \mathrm{C}\left\{{ }^{1} \mathrm{H}\right\} \mathrm{NMR}\left(100 \mathrm{MHz}, \mathrm{CDCl}_{3}\right)$ 156.2, 142.0, 129.8, 124.0, 121.74, 121.73, 117.5, 64.9, 23.6.

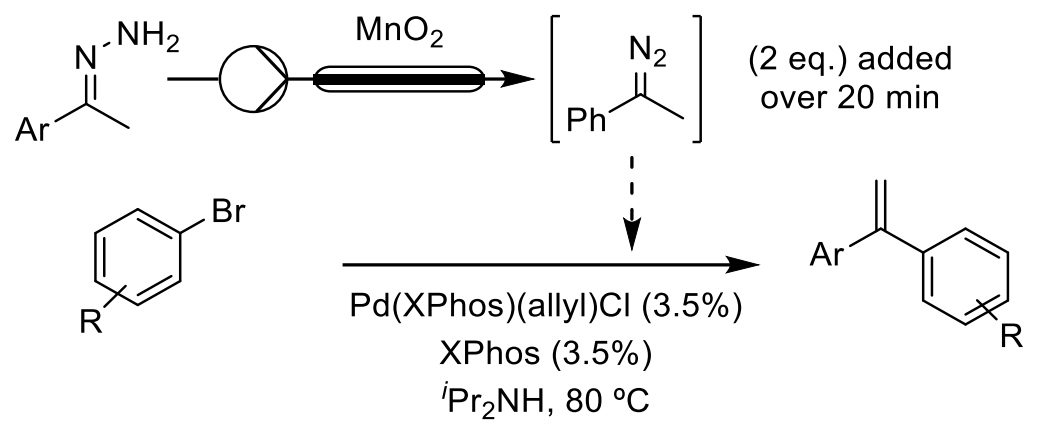

General Procedure for Diazo-Aryl Bromide Cross-Coupling. $\mathrm{Pd}(\mathrm{XPhos})($ allyl)Cl (4.6 mg, 7 $\mu \mathrm{mol})$, XPhos $(3.3 \mathrm{mg}, 7 \mu \mathrm{mol}$ ) and aryl bromide (if solid; $0.2 \mathrm{mmol}$ ) were placed in a $25 \mathrm{~mL}$ round bottom flask and flushed with Ar. Toluene $(1 \mathrm{~mL}),{ }^{i} \operatorname{Pr}_{2} \mathrm{NH}(28 \mu \mathrm{L}, 0.2 \mathrm{mmol})$ and aryl bromide (if liquid; $0.2 \mathrm{mmol})$ were added. Separately a $10.0 \mathrm{~mL}$ solution of hydrazone $(0.76 \mathrm{mmol})$ and ${ }^{i} \operatorname{Pr}_{2} \mathrm{NH}(213 \mu \mathrm{L}, 1.5 \mathrm{mmol})$ in toluene was prepared and loaded into a Hamilton air-tight ${ }^{\circledR}$ glass syringe and placed in a Nexus Fusion 200 syringe pump. The hydrazone solution was pumped at $0.5 \mathrm{~mL} / \mathrm{min}$ through a $5 \mathrm{~cm}$ long, $3 \mathrm{~mm}$ ID, 1/4" OD 316 stainless steel tubular reactor fitted with HPLC end frits and packed with $\mathrm{MnO}_{2}(\sim 370 \mathrm{mg}, 4 \mathrm{mmol})$, with the effluent passing through the flow IR and then directed into an $50 \%$ aqueous acetic acid quench. ${ }^{8}$ Once the $v\left(\mathrm{C}=\mathrm{N}=\mathrm{N}\right.$ ) vibration at $\sim 2040 \mathrm{~cm}^{-1}$ began to appear (after $\sim 90 \mathrm{~s}$ ) the flow rate was decreased to $0.35 \mathrm{~mL} / \mathrm{min}$ and the flask containing the $\mathrm{ArBr}$ solution was submerged in an $80{ }^{\circ} \mathrm{C}$ oil bath. After allowing $\sim 2$ min for the diazo peak to stabilize and the reaction flask to heat to temperature, the diazo solution was directed into the reaction flask for the next 20 min (7 $\mathrm{mL}$ of diazo solution added, $\sim 0.4 \mathrm{mmol} \sim 75 \%$ yield of diazo from hydrazone). Following the addition of the diazo the reaction flask was stirred an additional $15 \mathrm{~min}$, then cooled to room temperature and filtered through a plug of silica, eluting with 2:1 EtOAc:hexanes. The product was purified immediately by flash column chromatography. 
<smiles>C=C(c1ccccc1)c1ccccc1</smiles>

1,1-Diphenylethylene (2a). Prepared by the general procedure and purified on silica eluting with hexanes. Yield $32.7 \mathrm{mg}(90 \%)$ colourless oil. Characterization data were in agreement with the literature. ${ }^{15}{ }^{1} \mathrm{H}$ NMR $\left(400 \mathrm{MHz}, \mathrm{CDCl}_{3}\right) 7.36(\mathrm{~m}, 5 \mathrm{H}), 5.49(\mathrm{~s}, 2 \mathrm{H}) .{ }^{13} \mathrm{C}\left\{{ }^{1} \mathrm{H}\right\} \mathrm{NMR}(100 \mathrm{MHz}$, $\left.\mathrm{CDCl}_{3}\right) 150.2,141.6,128.4,128.3,127.8,114.4$.<smiles>C=C(c1ccccc1)c1ccc(C(F)(F)F)cc1</smiles>

1-(4-Trifluoromethylphenly)-1-phenylethylene (2b). Prepared by the general procedure and purified on silica eluting with hexanes. Yield $43.5 \mathrm{mg}(88 \%)$ white solid. Characterization data were in agreement with the literature. ${ }^{16}{ }^{1} \mathrm{H}$ NMR $\left(400 \mathrm{MHz}, \mathrm{CDCl}_{3}\right) 7.61(\mathrm{~d}, J=8.7 \mathrm{~Hz}, 2 \mathrm{H}), 7.47$ $(\mathrm{d}, J=8.7 \mathrm{~Hz}, 2 \mathrm{H}), 7.35(\mathrm{~m}, 5 \mathrm{H}), 5.58(\mathrm{~d}, J=1.0 \mathrm{~Hz}, 1 \mathrm{H}), 5.53(\mathrm{~d}, J=0.9 \mathrm{~Hz}, 1 \mathrm{H}) .{ }^{13} \mathrm{C}\left\{{ }^{1} \mathrm{H}\right\} \mathrm{NMR}$ $\left(100 \mathrm{MHz}, \mathrm{CDCl}_{3}\right) 149.1,145.2(\mathrm{q}, J=1.2 \mathrm{~Hz}), 140.8,129.9(\mathrm{q}, J=32.3 \mathrm{~Hz}), 128.7,128.5,128.3$, 128.2, $125.3(\mathrm{q}, J=3.8 \mathrm{~Hz}), 124.4(\mathrm{q}, J=272.0 \mathrm{~Hz}), 116.0 .{ }^{19} \mathrm{~F}\left\{{ }^{1} \mathrm{H}\right\} \mathrm{NMR}\left(376 \mathrm{MHz}, \mathrm{CDCl}_{3}\right)-$ 61.3 .<smiles>C=C(c1ccccc1)c1ccc([N+](=O)[O-])cc1</smiles>

1-(4-Nitrophenyl)-1-phenylethylene (2c). Prepared by the general procedure and purified on 5\% $\mathrm{AgNO}_{3}$ impregnated silica eluting with $2 \%$ EtOAc in hexanes. Yield $37.0 \mathrm{mg}(82 \%)$ colourless oil. Characterization data were in agreement with the literature. ${ }^{17}{ }^{1} \mathrm{H}$ NMR $\left(400 \mathrm{MHz}, \mathrm{CDCl}_{3}\right)$ $8.20(\mathrm{dt}, J=9.0,2.2 \mathrm{~Hz}, 2 \mathrm{H}), 7.50$ (dt, $J=8.9,2.2 \mathrm{~Hz}, 2 \mathrm{H}), 7.37$ (m, 3H), 7.29 (m, 2H), 5.64, (d, $J=0.7 \mathrm{~Hz}, 1 \mathrm{H}), 5.60(\mathrm{~d}, J=0.7 \mathrm{~Hz}, 1 \mathrm{H}) .{ }^{13} \mathrm{C}\left\{{ }^{1} \mathrm{H}\right\} \mathrm{NMR}\left(100 \mathrm{MHz}, \mathrm{CDCl}_{3}\right)$ 148.5, 148.2, 147.4, $140.3,129.1,128.6,128.5,128.3,123.7,117.4$.<smiles>C=C(c1ccccc1)c1ccc(C(=O)c2ccccc2)cc1</smiles>

1-(Benzophenon-4-yl)-1-phenylethylene (2d). Prepared by the general procedure and purified on $5 \% \mathrm{AgNO}_{3}$ impregnated silica eluting with 2\% EtOAc in hexanes. Yield $49.5 \mathrm{mg}(87 \%)$ white solid. Characterization data were in agreement with the literature. ${ }^{18}{ }^{1} \mathrm{H} \mathrm{NMR}\left(400 \mathrm{MHz}, \mathrm{CDCl}_{3}\right)$ $7.82(\mathrm{~m}, 4 \mathrm{H}), 7.60(\mathrm{tt}, J=7.4,2.1 \mathrm{~Hz}, 1 \mathrm{H}), 7.48(\mathrm{~m}, 4 \mathrm{H}), 7.36(\mathrm{~m}, 5 \mathrm{H}), 5.58(\mathrm{~s}, 2 \mathrm{H}) .{ }^{13} \mathrm{C}\left\{{ }^{1} \mathrm{H}\right\}$ NMR (100 MHz, $\left.\mathrm{CDCl}_{3}\right)$ 196.4, 149.4, 145.7, 140.9, 137.8, 136.8, 132.5, 130.2, 130.1, 128.45, $128.41,128.36,128.2,128.1,116.1$. 
<smiles>C=C(c1ccccc1)c1ccc(C)cc1</smiles>

1-Phenyl-1-(tol-4-yl)ethylene (2e). Prepared by the general procedure and purified on silica eluting with hexanes. Yield $32.8 \mathrm{mg}(84 \%)$ colourless oil. Characeterization data were in agreement with the literature. ${ }^{161} \mathrm{H}$ NMR $\left(400 \mathrm{MHz}, \mathrm{CDCl}_{3}\right) 7.36(\mathrm{~m} .5 \mathrm{H}), 7.28(\mathrm{~d}, J=8.1 \mathrm{~Hz}, 2 \mathrm{H}), 7.18(\mathrm{~d}, J=$ $8.2 \mathrm{~Hz}, 2 \mathrm{H}), 5.47(\mathrm{~d}, J=1.2 \mathrm{~Hz}, 1 \mathrm{H}), 5.44(\mathrm{~d}, J=1.2 \mathrm{~Hz}, 1 \mathrm{H}), 2.41(\mathrm{~s}, 3 \mathrm{H}) .{ }^{13} \mathrm{C}\left\{{ }^{1} \mathrm{H}\right\} \mathrm{NMR}(100$ $\mathrm{MHz}_{\mathrm{CDCl}}$ ) 150.0, 141.8, 138.7, 137.6, 129.0, 128.4, 128.3, 12.8.2, 127.8, 113.7, 21.3.<smiles>C=C(c1ccccc1)c1ccc(OC)c(C)c1</smiles>

1-(4-Methoxy-3-methylphenyl)-1-phenylethylene (2f). Prepared by the general procedure and purified on $5 \% \mathrm{AgNO}_{3}$ impregnated silica eluting with $2 \%$ EtOAc in hexanes. Yield $39.0 \mathrm{mg}$ (87\%) white solid. ${ }^{1} \mathrm{H}$ NMR $\left(400 \mathrm{MHz}, \mathrm{CDCl}_{3}\right) 7.37(\mathrm{~m}, 5 \mathrm{H}), 7.17(\mathrm{~m}, 2 \mathrm{H}), 6.81(\mathrm{~d}, J=8.9 \mathrm{~Hz}$, $1 \mathrm{H}), 5.42(\mathrm{~d}, J=1.4 \mathrm{~Hz}, 1 \mathrm{H}), 5.38(\mathrm{~d}, J=1.4 \mathrm{~Hz}, 1 \mathrm{H}), 3.87(\mathrm{~s}, 3 \mathrm{H}), 2.25(\mathrm{~d}, 3 \mathrm{H}) .{ }^{13} \mathrm{C}\left\{{ }^{1} \mathrm{H}\right\} \mathrm{NMR}$ $\left(100 \mathrm{MHz}, \mathrm{CDCl}_{3}\right)$ 157.7, 149.8, 142.1, 133.7, 130.6, 128.5, 128.2, 127.7, 126.9, 126.3, 112.9, 109.6, 55.5, 16.4. HRMS calcd for $\mathrm{C}_{16} \mathrm{H}_{16} \mathrm{O} 224.1201$; found 224.1282, spectral accuracy 99.0\%.<smiles>C=C(c1ccccc1)c1cc(C)ccc1C</smiles>

1-(2,5-dimethylphenyl)-1-phenylethylene (2g). Prepared by the general procedure and purified on silica eluting with hexanes. Yield $36.4 \mathrm{mg}(87 \%)$ colourless oil. Characterization data were in agreement with the literature. ${ }^{19}{ }^{1} \mathrm{H}$ NMR $\left(400 \mathrm{MHz} \mathrm{CDCl}_{3}\right) 7.31(\mathrm{~m}, 5 \mathrm{H}), 7.10(\mathrm{~m}, 3 \mathrm{H}), 5.79$ (d, $J=1.4 \mathrm{~Hz}, 1 \mathrm{H}), 5.22(\mathrm{~d}, J=1.4 \mathrm{~Hz}, 1 \mathrm{H}), 2.38(\mathrm{~s}, 3 \mathrm{H}), 2.05(\mathrm{~s}, 3 \mathrm{H}) .{ }^{13} \mathrm{C}\left\{{ }^{1} \mathrm{H}\right\} \mathrm{NMR}(100 \mathrm{MHz}$, $\left.\mathrm{CDCl}_{3}\right)$ 149.7, 141.6, 140.8, 135.2, 133.1, 130.8, 130.1, 128.4, 128.3, 127.6, 126.6, 114.8, 21.0, 19.7.<smiles>C=C(c1ccccc1)c1cc(OC)c(OC)cc1CC#N</smiles>

1-(2-Cyanomethyl-4,5-dimethoxy)-1-phenylethylene (2h). Prepared by the general procedure and purified on 5 silica eluting with 10:1 $\rightarrow 3: 1$ hexanes:EtOAc. Yield $54.8 \mathrm{mg}(98 \%)$ pale yellow oil. ${ }^{1} \mathrm{H}$ NMR $\left(400 \mathrm{MHz}, \mathrm{CDCl}_{3}\right) 7.28(\mathrm{~m}, 5 \mathrm{H}), 6.96(\mathrm{~s}, 1 \mathrm{H}), 6.78(\mathrm{~s}, 1 \mathrm{H}), 5.86(\mathrm{~d}, J=1.1 \mathrm{~Hz}, 1 \mathrm{H})$, $5.26(\mathrm{~d}, J=1.1 \mathrm{~Hz}, 1 \mathrm{H}), 3.94(\mathrm{~s}, 3 \mathrm{H}), 3.87(\mathrm{~s}, 3 \mathrm{H}), 3.42(\mathrm{~s}, 2 \mathrm{H}) .{ }^{13} \mathrm{C}\left\{{ }^{1} \mathrm{H}\right\} \mathrm{NMR}\left(100 \mathrm{MHz}, \mathrm{CDCl}_{3}\right)$ 148.9, 148.7, 147.3, 139.6, 133.7, 128.8, 128.4, 126.5, 120.2, 118.4, 116.5, 113.7, 111.7, 56.2, 56.1, 21.4. HRMS calcd for $\mathrm{C}_{18} \mathrm{H}_{17} \mathrm{NO}_{2} 279.1259$; found 279.1290, spectral accuracy 98.3\%. 
<smiles>C=C(c1ccccc1)c1ccc(CO)cc1</smiles>

1-(4-Hydroxymethylphenyl)-1-phenylethylene (2i). Prepared by the general procedure and purified on silica eluting with 5:1 $\rightarrow 3: 1$ hexanes:EtOAc. Yield $38.4 \mathrm{mg}(91 \%)$ white solid. Characterization data were in agreement with the literature. ${ }^{20}{ }^{1} \mathrm{H}$ NMR $\left(400 \mathrm{MHz}, \mathrm{CDCl}_{3}\right) 7.34(\mathrm{~m}, 9 \mathrm{H}), 5.48$ (s, 2H), 4.71 (s, 2H), 2.01 (br s, $1 \mathrm{H}) .{ }^{13} \mathrm{C}\left\{{ }^{1} \mathrm{H}\right\} \mathrm{NMR}\left(100 \mathrm{MHz}, \mathrm{CDCl}_{3}\right)$ 149.8, 141.5, 141.0, 140.4, $128.6,128.4,128.3,127.7,127.0,114.4,65.2$.<smiles>C=C(c1ccccc1)c1ccc(N)cc1</smiles>

1-(4-Aminophenyl)-1-phenylethylene (2j). Prepared by the general procedure and purified on silica eluting with 10: $\rightarrow 4: 1$ hexanes:EtOAc. Yield $28.5 \mathrm{mg}(73 \%)$ colourless oil. Characterization data were in agreement with the literature. ${ }^{17}{ }^{1} \mathrm{H}$ NMR $\left(400 \mathrm{MHz}, \mathrm{CDCl}_{3}\right) 7.33(\mathrm{~m}, 5 \mathrm{H}), 7.16(\mathrm{dt}, J=$ 8.6, $2.3 \mathrm{~Hz}, 2 \mathrm{H}), 6.65(\mathrm{dt}, J=8.7,2.4 \mathrm{H}, 2 \mathrm{H}), 5.38(\mathrm{~d}, J=1.4 \mathrm{~Hz}, 1 \mathrm{H}), 5.28(\mathrm{~d}, J=1.4 \mathrm{~Hz}, 1 \mathrm{H})$, 3.71 (br s, 2H). ${ }^{13} \mathrm{C}\left\{{ }^{1} \mathrm{H}\right\} \mathrm{NMR}\left(100 \mathrm{MHz}, \mathrm{CDCl}_{3}\right) 149.9,146.3,142.2,131.9,129.4,128.5,128.2$, 127.6, 114.7, 112.0.<smiles>C=C(c1ccccc1)c1ccc(Cl)cc1</smiles>

1-(4-Chlorophenyl)-1-phenylethylene (2k). Prepared by the general procedure and purified on silica eluting with hexanes. Yield $37.8 \mathrm{mg}(88 \%)$ colourless oil. Characterization data were in agreement with the literature. ${ }^{20}{ }^{1} \mathrm{H}$ NMR $\left(400 \mathrm{MHz} \mathrm{CDCl}_{3}\right) 7.32(\mathrm{~m}, 9 \mathrm{H}), 5.48(\mathrm{~d}, J=1.0 \mathrm{~Hz}$, $1 \mathrm{H}), 5.46(\mathrm{~d}, J=1.0 \mathrm{~Hz}, 1 \mathrm{H}) .{ }^{13} \mathrm{C}\left\{{ }^{1} \mathrm{H}\right\} \mathrm{NMR}\left(100 \mathrm{MHz}, \mathrm{CDCl}_{3}\right)$ 149.1, 141.1, 104.1, 133.7, 129.7, $128.5,128.4,128.3,128.1,114.8$.<smiles>C=C(c1ccccc1)c1ccsc1</smiles>

1-Phenyl-1-(thiophen-3-yl)ethylene (21). Prepared by the general procedure with $2 \times$ catalyst load (0.014 mmol Pd(XPhos)(allyl)Cl, 0.014 mmol XPhos) and purified on 5\% $\mathrm{AgNO}_{3}$ impregnated silica eluting with $0.5 \%$ EtOAc in hexanes. Yield $26.3 \mathrm{mg}(70 \%)$ colourless oil. Characterization data were in agreement with the literature. ${ }^{17}{ }^{1} \mathrm{H}$ NMR $\left(400 \mathrm{MHz}, \mathrm{CDCl}_{3}\right) 7.38(\mathrm{~m}, 5 \mathrm{H}), 7.31$ (dd, $J=5.0,3.0 \mathrm{~Hz}, 1 \mathrm{H}), 7.19(\mathrm{dd}, J=5.0,1.3 \mathrm{~Hz}, 1 \mathrm{H}), 7.14(\mathrm{dd}, J=3.0,1.3 \mathrm{~Hz}, 1 \mathrm{H}), 5.55(\mathrm{~d}, J=1.2$ $\mathrm{Hz}, 1 \mathrm{H}), 5.35(\mathrm{~d}, J=1.2 \mathrm{~Hz}, 1 \mathrm{H}) .{ }^{13} \mathrm{C}\left\{{ }^{1} \mathrm{H}\right\} \mathrm{NMR}\left(100 \mathrm{MHz}, \mathrm{CDCl}_{3}\right)$ 144.7, 142.7, 141.6, 128.3, $128.2,127.9,127.3,125.6,123.4,113.6$. 
<smiles>C=C(c1ccccc1)c1ccc(C(=O)OC)o1</smiles>

1-(5-Methoxycarbonylfuran-2-yl)-1-phenylethylene (2m). Prepared by the general procedure with $2 \times$ catalyst load $\left(0.014 \mathrm{mmol} \mathrm{Pd}(\mathrm{XPhos})(\right.$ allyl)Cl, $0.014 \mathrm{mmol} \mathrm{XPhos})$ and purified on $5 \% \mathrm{AgNO}_{3}$ impregnated silica eluting with $4 \%$ EtOAc in hexanes. Yield $32.2 \mathrm{mg}(71 \%)$ colourless oil. ${ }^{1} \mathrm{H}$ NMR (400 MHz, $\left.\mathrm{CDCl}_{3}\right) 7.40(\mathrm{~m}, 5 \mathrm{H}), 7.16(\mathrm{~d}, J=3.6 \mathrm{~Hz}, 1 \mathrm{H}), 6.27(\mathrm{~s}, J=3.6 \mathrm{~Hz}, 1 \mathrm{H}), 6.01$ (d, $J=0.5 \mathrm{~Hz}, 1 \mathrm{H}), 5.42(\mathrm{~d}, J=0.7 \mathrm{~Hz}, 1 \mathrm{H}), 3.91(\mathrm{~s}, 3 \mathrm{H}) .{ }^{13} \mathrm{C}\left\{{ }^{1} \mathrm{H}\right\} \mathrm{NMR}\left(100 \mathrm{MHz}, \mathrm{CDCl}_{3}\right) 159.3$, $157.5,143.9,138.7,138.6,128.25,128.47,128.4,119.6,116.0,111.0,52.0$. IR v(C=O) $1721 \mathrm{~cm}^{-}$ 1. HRMS calcd for $\mathrm{C}_{14} \mathrm{H}_{12} \mathrm{O}_{3} 228.0786$; found 228.0791, spectral accuracy $99.6 \%$.<smiles>C=C(c1ccccc1)c1ccc2[nH]ccc2c1</smiles>

1-(Indol-5-yl)-1-phenylethylene (2n). Prepared by the general procedure and purified on silica eluting with 10:1 $\rightarrow 5: 1$ hexanes:EtOAc. Yield $38.6 \mathrm{mg}(88 \%)$ white solid. ${ }^{1} \mathrm{H}$ NMR (400 MHz, $\left.\mathrm{CDCl}_{3}\right) 8.12$ (br s, $\left.1 \mathrm{H}\right), 7.64(\mathrm{~m}, 1 \mathrm{H}), 7.43(\mathrm{~m}, 2 \mathrm{H}), 7.35(\mathrm{~m}, 4 \mathrm{H}), 7.22(\mathrm{~m}, 2 \mathrm{H}), 6.55(\mathrm{~m}, 1 \mathrm{H})$, $5.49(\mathrm{~d}, J=1.4 \mathrm{~Hz}, 1 \mathrm{H}), 5.44(\mathrm{~d}, J=1.4 \mathrm{~Hz}, 1 \mathrm{H}) .{ }^{13} \mathrm{C}\left\{{ }^{1} \mathrm{H}\right\} \mathrm{NMR}\left(100 \mathrm{MHz}, \mathrm{CDCl}_{3}\right)$ 151.1, 142.6, 135.6, 133.7, 128.6, 128.2, 127.9, 127.6, 124.8, 123.0, 120.8, 113.1, 110.7, 103.1. HRMS calcd for $\mathrm{C}_{16} \mathrm{H}_{13} \mathrm{~N} 219.1048$; found 219.1094, spectral accuracy $99.3 \%$.<smiles>C=C(c1ccccc1)c1ccc2c(c1)NC(=O)C2</smiles>

1-(2-Oxindol-6-y)-1-phenylethylene (2o). Prepared by the general procedure and purified on silica eluting with 2:1 hexanes:EtOAc. Yield $41.0 \mathrm{mg}(87 \%)$ white solid. ${ }^{1} \mathrm{H}$ NMR $\left(400 \mathrm{MHz}, \mathrm{CDCl}_{3}\right)$ $8.21($ br s, $1 \mathrm{H}), 7.33(\mathrm{~m}, 5 \mathrm{H}), 7.19(\mathrm{~d}, J=7.7 \mathrm{~Hz}, 1 \mathrm{H}), 7.02(\mathrm{dd}, J=7.7,1.3 \mathrm{~Hz}, 1 \mathrm{H}), 6.84(\mathrm{~d}, J=$ $1.3 \mathrm{~Hz}), 5.45$ (s, 2H), 3.55 (s, 2H). ${ }^{13} \mathrm{C}\left\{{ }^{1} \mathrm{H}\right\} \mathrm{NMR}\left(100 \mathrm{MHz}, \mathrm{CDCl}_{3}\right)$ 177.5, 149.9, 142.5, 141.9, $141.4,128.39,128.38,128.0,124.9,124.5,122.7,114.7,109.7,36.1$. IR $v(\mathrm{C}=\mathrm{O}) 1693 \mathrm{~cm}^{-1}$. HRMS calcd for $\mathrm{C}_{16} \mathrm{H}_{13} \mathrm{NO} 235.0997$; found 235.1003, spectral accuracy $99.4 \%$.<smiles>C=C(c1ccc2ccccc2c1)c1ccc2[nH]ccc2c1</smiles>

1-(Indol-5-yl)-1-(2-naphthyl)ethylene (3a). Prepared by the general procedure and purified on silica eluting with 10:1 $\rightarrow 5: 1$ hexanes:EtOAc. Yield $47.5 \mathrm{mg}(88 \%)$ off-white solid. ${ }^{1} \mathrm{H}$ NMR (400 $\left.\mathrm{MHz} \mathrm{CDCl}_{3}\right) 8.14$ (br s, $\left.1 \mathrm{H}\right), 7.80(\mathrm{~m}, 4 \mathrm{H}), 7.65(\mathrm{~m}, 1 \mathrm{H}), 7.52(\mathrm{dd}, J=8.5,1.7 \mathrm{~Hz}, 1 \mathrm{H}), 7.45(\mathrm{~m}$, $2 \mathrm{H}), 7.35(\mathrm{~d}, J=8.5 \mathrm{~Hz}, 1 \mathrm{H}), 7.24(\mathrm{dd}, J=8.4,1.7 \mathrm{~Hz}, 1 \mathrm{H}), 7.21(\mathrm{~m}, 1 \mathrm{H}), 6.52(\mathrm{~m}, 1 \mathrm{H}), 5.54(\mathrm{~d}$, $J=1.4 \mathrm{~Hz}, 1 \mathrm{H}), 5.53(\mathrm{~d}, J=1.4 \mathrm{~Hz}, 1 \mathrm{H}) .{ }^{13} \mathrm{C}\left\{{ }^{1} \mathrm{H}\right\} \mathrm{NMR}\left(100 \mathrm{MHz}, \mathrm{CDCl}_{3}\right)$ 151.1, 140.1, 135.7, 
133.8, 133.5, 133.1, 128.4, 127.9, 127.7, 127.6, 127.5, 126.9, 126.2, 126.0, 124.8, 123.1, 121.0, 113.7, 110.8, 103.2. HRMS calcd for $\mathrm{C}_{20} \mathrm{H}_{15} \mathrm{~N}$ 269.1204; found 269.1207, spectral accuracy $99.0 \%$.<smiles>C=C(c1ccc(C(=O)OC)cc1)c1ccc2[nH]ccc2c1</smiles>

1-(Indol-5-yl)-1-(4-methoxycarbonyphenyl)ethylene (3b). Prepared by the general procedure with hydrazone solution prepared at $1 / 2$ dilution $(0.76 \mathrm{mmol}$ in $20.0 \mathrm{~mL}$ solution) and pumped at $2 \times$ flow rate $(0.7 \mathrm{~mL} / \mathrm{min})$ due to limited solubility. Purified on silica eluting with 5:1 hexanes:EtOAc $\rightarrow 5 \%$ $\mathrm{MeCN}$ in 5:1 hexanes:EtOAc. Yield $44.3 \mathrm{mg}(80 \%)$ white solid. ${ }^{1} \mathrm{H} \mathrm{NMR}\left(400 \mathrm{MHz}, \mathrm{CDCl}_{3}\right) 8.21$ (br s, $1 \mathrm{H}), 8.01(\mathrm{~d}, J=8.3 \mathrm{~Hz}, 2 \mathrm{H}), 7.58(\mathrm{~s}, 1 \mathrm{H}), 7.46(\mathrm{~d}, J=8.3 \mathrm{~Hz}, 2 \mathrm{H}), 7.36(\mathrm{~d}, J=8.5 \mathrm{~Hz}, 1 \mathrm{H})$, $7.23(\mathrm{t}, J=2.9 \mathrm{~Hz}, 1 \mathrm{H}), 7.17(\mathrm{dd}, J=8.5,1.3 \mathrm{~Hz}, 1 \mathrm{H}), 6.54(\mathrm{~m}, 1 \mathrm{H}), 5.55(\mathrm{~s}, 1 \mathrm{H}), 5.49(\mathrm{~s}, 1 \mathrm{H})$, $3.93(\mathrm{~s}, 3 \mathrm{H}) .{ }^{13} \mathrm{C}\left\{{ }^{1} \mathrm{H}\right\}$ NMR (100 MHz, $\left.\mathrm{CDCl}_{3}\right)$ 167.2, 150.4, 147.3, 135.7, 133.0, 129.6, 129.2, 128.6, 127.9, 125.0, 122.9, 120.8, 114.7, 110.9, 103.2, 52.2. IR v(C=O) $1691 \mathrm{~cm}^{-1}$. HRMS calcd for $\mathrm{C}_{18} \mathrm{H}_{15} \mathrm{NO}_{2} 277.1103$; found 277.1206, spectral accuracy $99.5 \%$.<smiles>C=C(c1ccc(OC)cc1)c1ccc2[nH]ccc2c1</smiles>

1-(Indol-5-yl)-1-(4-methoxyphenyl)ethylene (3c). Prepared by the general procedure and purified on 5\% $\mathrm{AgNO}_{3}$ impregnated silica eluting with 5:1 $\rightarrow 5: 2$ hexanes:EtOAc. Yield $30.3 \mathrm{mg}(61 \%)$ white solid. ${ }^{1} \mathrm{H}$ NMR $\left(400 \mathrm{MHz}, \mathrm{CDCl}_{3}\right) 8.15(\mathrm{br} \mathrm{s}, 1 \mathrm{H}), 7.62(\mathrm{~m}, 1 \mathrm{H}), 7.34(\mathrm{~m}, 3 \mathrm{H}), 7.21(\mathrm{~m}$, $2 \mathrm{H}), 6.88(\mathrm{~m}, 2 \mathrm{H}), 6.53(\mathrm{~m}, 1 \mathrm{H}), 5.36(\mathrm{~d}, J=1.5 \mathrm{~Hz}, 1 \mathrm{H}), 5.35(\mathrm{~d}, J=1.5 \mathrm{~Hz}, 1 \mathrm{H}), 3.83(\mathrm{~s}, 3 \mathrm{H})$. ${ }^{13} \mathrm{C}\left\{{ }^{1} \mathrm{H}\right\}$ NMR (100 MHz, $\left.\mathrm{CDCl}_{3}\right)$ 159.3, 150.5, 135.6, 135.2, 134.0, 129.7, 127.9, 124.7, 123.1, 120.8, 113.5, 111.8, 110.6, 103.1, 55.4. HRMS calcd for $\mathrm{C}_{17} \mathrm{H}_{15} \mathrm{NO} 249.1154$; found 249.1138, spectral accuracy $98.7 \%$.<smiles>C=C(c1ccc2[nH]ccc2c1)c1ccc(C)cc1C</smiles>

1-(Indol-5-yl)-1-(2,4-dimethylphenyl)ethylene (3d). Prepared by the general procedure with the packed column of $\mathrm{MnO}_{2}$ cooled in an ice bath at $0{ }^{\circ} \mathrm{C}$ and purified on $5 \% \mathrm{AgNO}_{3}$ impregnated silica eluting with 10:1 $\rightarrow 5: 1$ hexanes:EtOAc. Yield $42.2 \mathrm{mg}(85 \%)$ colourless oil. ${ }^{1} \mathrm{H}$ NMR (400 $\left.\mathrm{MHz}, \mathrm{CDCl}_{3}\right) 8.07$ (br s, $\left.1 \mathrm{H}\right), 7.49(\mathrm{~m}, 1 \mathrm{H}), 7.27(\mathrm{~m}, 2 \mathrm{H}), 7.20(\mathrm{~d}, J=7.5 \mathrm{~Hz}, 1 \mathrm{H}), 7.17$ (dd, $J=$ $3.1,2.6 \mathrm{~Hz}, 1 \mathrm{H}), 7.06(\mathrm{~m}, 2 \mathrm{H}), 6.49(\mathrm{~m}, 1 \mathrm{H}), 5.75(\mathrm{~d}, J=1.7 \mathrm{~Hz}, 1 \mathrm{H}), 5.13(\mathrm{~d}, J=1.6 \mathrm{~Hz}, 1 \mathrm{H})$, $2.40(\mathrm{~s}, 3 \mathrm{H}), 2.07(\mathrm{~d}, 3 \mathrm{H}) .{ }^{13} \mathrm{C}\left\{{ }^{1} \mathrm{H}\right\}$ NMR $\left(100 \mathrm{MHz}, \mathrm{CDCl}_{3}\right) 150.3,139.9,137.0,136.3,135.5$, 133.2, 131.0, 130.2, 128.0, 126.3, 124.7, 121.2, 119.2, 113.0, 110.9, 130.3, 21.3, 20.2. HRMS calcd for $\mathrm{C}_{18} \mathrm{H}_{17} \mathrm{~N} 247.1361$; found 247.1387, spectral accuracy 99.4\%. 
<smiles>C=C(c1ccc2[nH]ccc2c1)c1cccs1</smiles>

1-(Indol-5-yl)-1-(thiophen-2-yl)ethylene (3e). Prepared by the general procedure and purified on silica eluting with 8:1 hexanes:EtOAc. Yield $34.6 \mathrm{mg}(77 \%)$ off-white solid. ${ }^{1} \mathrm{H}$ NMR (400 MHz, $\left.\mathrm{CDCl}_{3}\right) 8.17$ (br s, $\left.1 \mathrm{H}\right), 7.74(\mathrm{~m}, 1 \mathrm{H}), 7.38(\mathrm{~d}, J=8.4 \mathrm{~Hz}, 1 \mathrm{H}), 7.30(\mathrm{dd}, J=8.4,1.6 \mathrm{~Hz}, 1 \mathrm{H}), 7.24$ $(\mathrm{m}, 2 \mathrm{H}), 6.98(\mathrm{~m}, 2 \mathrm{H}), 6.56(\mathrm{~m}, 1 \mathrm{H}), 5.57(\mathrm{~d}, J=1.0 \mathrm{~Hz}, 1 \mathrm{H}), 5.27(\mathrm{~d}, J=1.0 \mathrm{~Hz}, 1 \mathrm{H}) .{ }^{13} \mathrm{C}\left\{{ }^{1} \mathrm{H}\right\}$ NMR (100 MHz, $\left.\mathrm{CDCl}_{3}\right)$ 146.0, 144.3, 135.8, 133.3, 127.8, 127.3, 126.6, 124.91, 124.87, 123.1, 120.8, 112.8, 110.7, 103.2. HRMS calcd for $\mathrm{C}_{14} \mathrm{H}_{11} \mathrm{NS} 225.0612$; found 225.0594, spectral accuracy $99.3 \%$.

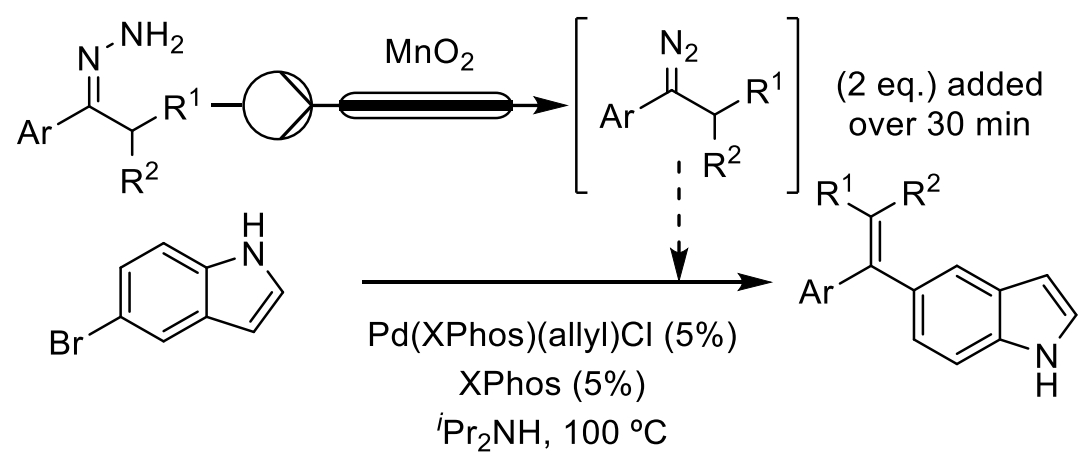

General Procedure for the Synthesis of Tri- and Tetrasubstituted Olefins. $\mathrm{Pd}$ (XPhos)(allyl)Cl $(6.6 \mathrm{mg}, 10 \mu \mathrm{mol})$, XPhos $(4.8 \mathrm{mg}, 10 \mu \mathrm{mol})$ and 5-bromoindole $(39.2 \mathrm{mg}, 0.2 \mathrm{mmol})$ were placed in a $25 \mathrm{~mL}$ round bottom flask and flushed with Ar. Toluene $(1 \mathrm{~mL})$ and ${ }^{i} \operatorname{Pr}_{2} \mathrm{NH}(28 \mu \mathrm{L}, 0.2 \mathrm{mmol})$ were added. Separately a $10.0 \mathrm{~mL}$ solution of hydrazone $(0.76 \mathrm{mmol})$ and ${ }^{i} \operatorname{Pr}_{2} \mathrm{NH}(213 \mu \mathrm{L}, 1.5$ mmol) in toluene was prepared and loaded into a Hamilton air-tight ${ }^{\circledR}$ glass syringe and placed in a Nexus Fusion 200 syringe pump. The hydrazone solution was pumped at $0.5 \mathrm{~mL} / \mathrm{min}$ through the packed column of $\mathrm{MnO} 2$ described previously, then the flow rate was decreased to 0.23 $\mathrm{mL} / \mathrm{min}$ once the diazo IR peak began to appear at $\sim 2040 \mathrm{~cm}^{-1}$. The flask containing the 5bromoindole solution was submerged in a $100{ }^{\circ} \mathrm{C}$ oil bath. After allowing $\sim 2 \mathrm{~min}$ for the diazo peak to stabilize and the reaction flask to heat to temperature, the diazo solution was directed into the reaction flask for the next $30 \mathrm{~min}(10.5 \mathrm{~mL}$ of diazo solution, $\sim 0.6 \mathrm{mmol}$ given $\sim 75 \%$ yield of diazo from hydrazone). Following the addition of the diazo the reaction flask was stirred an additional $15 \mathrm{~min}$, then cooled to room temperature and filtered through a plug of silica, eluting with 2:1 EtOAc:hexanes. The product was purified immediately by flash column chromatography.<smiles>CC(C)=C(c1ccccc1)c1ccc2[nH]ccc2c1</smiles> 
1-(Indol-5-yl)-2-methyl-1-phenylprop-1-ene (3f). Prepared by the general procedure and purified on 5\% $\mathrm{AgNO}_{3}$ impregnated silica eluting with $4: 1 \rightarrow 2: 1$ hexanes:EtOAc. Yield $35.9 \mathrm{mg}(73 \%)$ colourless oil. ${ }^{1} \mathrm{H}$ NMR $\left(400 \mathrm{MHz}, \mathrm{CDCl}_{3}\right) 8.07$ (br s, 1H), $7.43(\mathrm{~s}, 1 \mathrm{H}), 7.28(\mathrm{~m}, 3 \mathrm{H}), 7.17(\mathrm{~m}$, $4 \mathrm{H}), 6.97(\mathrm{dd}, J=8.4,1.5 \mathrm{~Hz}, 1 \mathrm{H}), 6.50(\mathrm{~m}, 1 \mathrm{H}), 1.85(\mathrm{~s}, 3 \mathrm{H}), 1.84(\mathrm{~s}, 3 \mathrm{H}) .{ }^{13} \mathrm{C}\left\{{ }^{1} \mathrm{H}\right\}$ NMR $(100$ $\left.\mathrm{MHz}, \mathrm{CDCl}_{3}\right)$ 144.3, 138.0, 135.4, 134.5, 130.2, 130.0, 127.9, 127.7, 125.9, 124.7, 124.4, 121.9, 110.5, 102.8, 22.8, 22.7. HRMS calcd for $\mathrm{C}_{18} \mathrm{H}_{17} \mathrm{~N} 247.1361$; found 247.1350, spectral accuracy $98.8 \%$.<smiles>c1ccc(C(=C2CCCCC2)c2ccc3[nH]ccc3c2)cc1</smiles>

2-(Indol-5-yl)-2-phenylmethylenecyclohexane (3g). Prepared by the general procedure and purified on silica eluting with 6:1 hexanes:EtOAc. Yield $26.8 \mathrm{mg}(47 \%)$ white solid. ${ }^{1} \mathrm{H}$ NMR (400 $\left.\mathrm{MHz}, \mathrm{CDCl}_{3}\right) 8.06$ (br s, 1H), $7.41(\mathrm{~s}, 1 \mathrm{H}), 7.27$ (m, 3H), $7.16(\mathrm{~m}, 4 \mathrm{H}), 6.96$ (dd, J = 8.3, $1.6 \mathrm{~Hz}$, $1 \mathrm{H}), 6.50(\mathrm{~m}, 1 \mathrm{H}), 2.29(\mathrm{~m}, 4 \mathrm{H}), 1.62(\mathrm{~m}, 6 \mathrm{H}) .{ }^{13} \mathrm{C}\left\{{ }^{1} \mathrm{H}\right\} \mathrm{NMR}\left(100 \mathrm{MHz}, \mathrm{CDCl}_{3}\right)$ 144.1, 138.4, $135.4,135.1,134.5,130.0,127.9,127.7,125.9$, 124.7, 124.4, 121.8, 110.5, 102.8, 32.7, 32.6, 28.90, 28.86, 27.1. HRMS calcd for $\mathrm{C}_{21} \mathrm{H}_{21} \mathrm{~N} 287.1674$; found 287.1661, spectral accuracy 98.9\%.<smiles>C1=C(c2ccc3[nH]ccc3c2)c2ccccc2OC1</smiles>

5-(2H-chromen-4-yl)indole (3h). Prepared by the general procedure and purified on silica eluting with 6:1 hexanes:EtOAc. Yield $21.3 \mathrm{mg}(43 \%)$ off-white solid. ${ }^{1} \mathrm{H} \mathrm{NMR}\left(400 \mathrm{MHz}, \mathrm{CDCl}_{3}\right) 8.20$ (br s, 1H), $7.64(\mathrm{~s}, 1 \mathrm{H}), 7.41(\mathrm{~d}, J=8.4 \mathrm{~Hz}, 1 \mathrm{H}), 7.26(\mathrm{~m}, 1 \mathrm{H}), 7.17(\mathrm{~m}, 2 \mathrm{H}), 7.09(\mathrm{dd}, J=7.6,1.5$ $\mathrm{Hz}, 1 \mathrm{H}), 6.91(\mathrm{dd}, J=8.0,1.0 \mathrm{~Hz}, 1 \mathrm{H}), 6.85(\mathrm{td}, J=7.5,1.1 \mathrm{~Hz}, 1 \mathrm{H}), 6.58(\mathrm{~m}, 1 \mathrm{H}), 5.83(\mathrm{t}, J=$ $3.9 \mathrm{~Hz}, 1 \mathrm{H}), 4.88(\mathrm{~d}, J=4.0 \mathrm{~Hz}, 2 \mathrm{H}) .{ }^{13} \mathrm{C}\left\{{ }^{1} \mathrm{H}\right\} \mathrm{NMR}\left(100 \mathrm{MHz}, \mathrm{CDCl}_{3}\right) 155.0,138.1,135.6$, 130.2, 129.1, 128.0, 126.4, 124.9, 124.7, 123.2, 121.2, 120.9, 119.4, 116.2, 110.9, 103.0, 65.6. HRMS calcd for $\mathrm{C}_{17} \mathrm{H}_{13} \mathrm{NO} 247.0997$; found 247.1006, spectral accuracy $98.9 \%$.<smiles>CC=C(c1cccc(OC)c1)c1ccc2[nH]ccc2c1</smiles>

1-(Indol-5-yl)-1-(3-methoxyphenyl)prop-1-ene (3i). Prepared by the general procedure and purified on silica eluting with 6:1 hexanes:EtOAc. Yield $45.8 \mathrm{mg}(87 \%)$ colourless oil as a mixture of 2.3:1 Z: $E$ isomers (determined by ${ }^{1} \mathrm{H}$ NMR analysis of the mixture). HRMS calc for $\mathrm{C}_{18} \mathrm{H}_{17} \mathrm{NO}$ 263.1310; found 263.1361, spectral accuracy $99.3 \%$ 
Complete separation of the isomers was not possible, but partial separation on $5 \% \mathrm{AgNO}_{3}$ impregnated silica eluting with 2:1 hexanes:EtOAc allowed enrichment of each individual isomer to $>10: 1$ purity for individual characterization.<smiles>C/C=C(\c1cccc(OC)c1)c1ccc2[nH]ccc2c1</smiles>

(Z)-1-(Indol-5-yl)-1-(3-methoxyphenyl)prop-1-ene. ${ }^{1} \mathrm{H} \mathrm{NMR}\left(400 \mathrm{MHz}, \mathrm{CDCl}_{3}\right) 8.07$ (br s, 1H), $7.46(\mathrm{~m}, 1 \mathrm{H}), 7.29(\mathrm{~m}, 2 \mathrm{H}), 7.15(\mathrm{~m}, 2 \mathrm{H}), 6.83(\mathrm{~m}, 3 \mathrm{H}), 6.48(\mathrm{~m}, 1 \mathrm{H}), 6.14(\mathrm{q}, J=7.0 \mathrm{~Hz}, 1 \mathrm{H})$, $3.80(\mathrm{~s}, 3 \mathrm{H}), 1.79(\mathrm{~d}, J=7.0 \mathrm{~Hz}, 3 \mathrm{H}) .{ }^{13} \mathrm{C}\left\{{ }^{1} \mathrm{H}\right\} \mathrm{NMR}\left(100 \mathrm{MHz}, \mathrm{CDCl}_{3}\right) 159.5,143.2,142.6$, 135.3, 135.1, 129.1, 127.9, 124.6, 122.9, 122.5, 122.0, 119.7, 115.7, 112.4, 110.6, 103.1, 55.3, 15.9.<smiles>C/C=C(\c1cccc(OC)c1)c1ccc2[nH]ccc2c1</smiles>

(E)-1-(Indol-5-yl)-1-(3-methoxyphenyl)prop-1-ene. $\left.{ }^{1} \mathrm{H} \mathrm{NMR} \mathrm{(400} \mathrm{MHz,} \mathrm{CDCl}_{3}\right) 8.15$ (br s, 1H), $7.48(\mathrm{~m}, 1 \mathrm{H}), 7.38(\mathrm{~d}, J=8.4 \mathrm{~Hz}, 1 \mathrm{H}), 7.23(\mathrm{t}, J=2.7 \mathrm{~Hz}, 1 \mathrm{H}), 7.16(\mathrm{t}, J=8.0 \mathrm{~Hz}, 1 \mathrm{H}), 6.99$ (dd, $J=8.3,1.6 \mathrm{~Hz}, 1 \mathrm{H}), 7.87(\mathrm{~m}, 2 \mathrm{H}), 6.76(\mathrm{ddd}, J=8.1,2.6,0.8 \mathrm{~Hz}, 1 \mathrm{H}), 6.54(\mathrm{~m}, 1 \mathrm{H}), 6.19(\mathrm{q}, J=$ $7.0 \mathrm{~Hz}, 1 \mathrm{H}), 3.75(\mathrm{~s}, 3 \mathrm{H}), 1.80(\mathrm{~d}, J=7.0 \mathrm{~Hz}, 3 \mathrm{H}) .{ }^{13} \mathrm{C}\left\{{ }^{1} \mathrm{H}\right\} \mathrm{NMR}\left(100 \mathrm{MHz}, \mathrm{CDCl}_{3}\right)$ 159.5, 145.6, 143.3, 135.0, 131.6, 128.9, 127.9, 124.7, 124.4, 123.9, 122.3, 120.2, 113.3, 112.0, 110.8, 102.9, $55.3,16.0$.

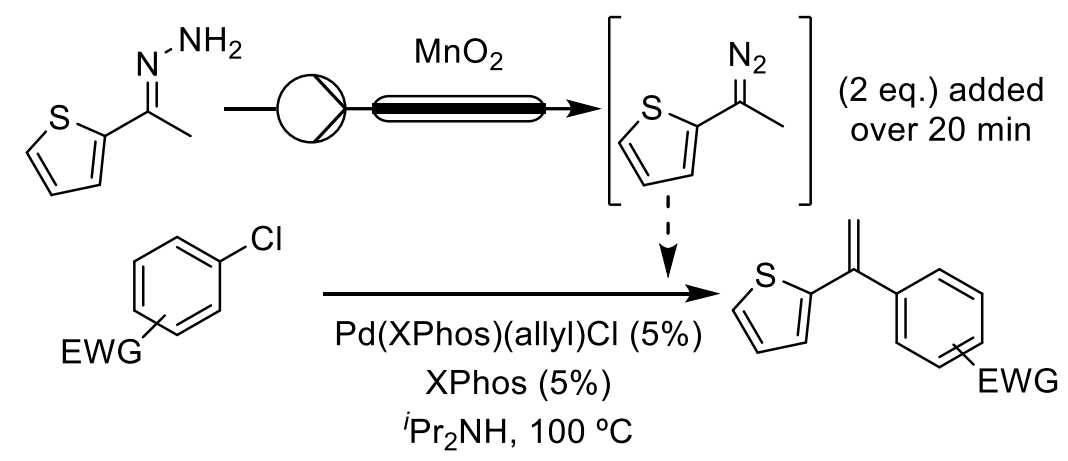

General Procedure for Diazo-Activated Aryl Chloride Cross-Coupling. $\mathrm{Pd}(\mathrm{XPhos})($ allyl)Cl (6.6 mg, $10 \mu \mathrm{mol})$, XPhos $(4.8 \mathrm{mg}, 10 \mu \mathrm{mol})$ and aryl chloride $(0.2 \mathrm{mmol})$ were placed in a $25 \mathrm{~mL}$ round bottom flask and flushed with Ar. Toluene $(1 \mathrm{~mL})$ and ${ }^{i} \operatorname{Pr}_{2} \mathrm{NH}(28 \mu \mathrm{L}, 0.2 \mathrm{mmol})$ were added. Separately a $10.0 \mathrm{~mL}$ solution of 2-acetylthiophene hydrazone (106 mg, $0.76 \mathrm{mmol})$ and ${ }^{i} \operatorname{Pr}_{2} \mathrm{NH}(213 \mu \mathrm{L}, 1.5 \mathrm{mmol})$ in toluene was prepared and loaded into a Hamilton air-tight ${ }^{\circledR}$ glass syringe and placed in a Nexus Fusion 200 syringe pump. The hydrazone solution was pumped at 
$0.5 \mathrm{~mL} / \mathrm{min}$ through the packed column of $\mathrm{MnO}_{2}$ described previously and cooled at $0{ }^{\circ} \mathrm{C}$, then the flow rate was decreased to $0.35 \mathrm{~mL} / \mathrm{min}$ once the diazo IR peak began to appear at $\sim 2040$ $\mathrm{cm}^{-1}$. The flask containing the 5-bromoindole solution was submerged in a $100{ }^{\circ} \mathrm{C}$ oil bath. After allowing $\sim 2 \mathrm{~min}$ for the diazo peak to stabilize and the reaction flask to heat to temperature, the diazo solution was directed into the reaction flask for the next 20 min $(7$ $\mathrm{mL}$ of diazo solution, $\sim 0.4 \mathrm{mmol}$ given $\sim 75 \%$ yield of diazo from hydrazone). Following the addition of the diazo the reaction flask was stirred an additional $5 \mathrm{~min}$, then cooled to room temperature and filtered through a plug of silica, eluting with 2:1 Et0Ac:hexanes. The product was purified immediately by flash column chromatography.

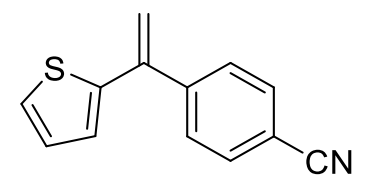

1-(4-Cyanophenyl)-1-(thiphen-2-yl)ethylene (4a). Prepared by the general procedure and purified on $5 \% \mathrm{AgNO}_{3}$ imprgenated silica eluting with $5 \%$ EtOAc in hexanes $\rightarrow 1 \% \mathrm{MeCN}, 10 \% \mathrm{EtOAc}$ in hexanes. Yield $29.3 \mathrm{mg}(69 \%)$ bright yellow oil. ${ }^{1} \mathrm{H}$ NMR (400 MHz, $\left.\mathrm{CDCl}_{3}\right) 7.66$ (dt, $J=8.6,2.0$ $\mathrm{Hz}, 2 \mathrm{H}), 7.54(\mathrm{dt}, J=8.6,2.0 \mathrm{~Hz}, 2 \mathrm{H}), 7.27(\mathrm{dd}, J=5.1,1.1 \mathrm{~Hz}, 1 \mathrm{H}), 6.99(\mathrm{dd}, J=5.1,3.6 \mathrm{~Hz}$, $1 \mathrm{H}), 6.85(\mathrm{dd}, J=3.6,1.1 \mathrm{~Hz}, 1 \mathrm{H}), 5.68(\mathrm{~s}, 1 \mathrm{H}), 5.32(\mathrm{~s}, 1 \mathrm{H}) .{ }^{13} \mathrm{C}\left\{{ }^{1} \mathrm{H}\right\} \mathrm{NMR}\left(100 \mathrm{MHz}, \mathrm{CDCl}_{3}\right)$

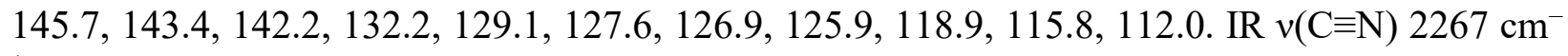
${ }^{1}$. HRMS calcd for $\mathrm{C}_{13} \mathrm{H}_{9} \mathrm{NS} 211.0456$; found 211.0507, spectral accuracy $99.1 \%$.<smiles>C=C(c1ccc(C(=O)c2ccccc2)cc1)c1cccs1</smiles>

1-(Benzophenon-4-yl)-1-(thiophen-2-yl)ethylene (4b). Prepared by the general procedure and purified on 5\% $\mathrm{AgNO}_{3}$ impregnated silica eluting with $2 \rightarrow 3 \%$ EtOAc in hexanes. Yield $42.0 \mathrm{mg}$ (72\%) off-white solid. ${ }^{1} \mathrm{H}$ NMR (400 MHz, $\left.\mathrm{CDCl}_{3}\right) 7.85$ (m, 4Hz), 7.55 (m, 5H), 7.27 (dd, J= 5.2, $1.0 \mathrm{~Hz}, 1 \mathrm{H}), 7.00(\mathrm{dd}, J=5.1,3.6 \mathrm{~Hz}, 1 \mathrm{H}), 6.93(\mathrm{dd}, J=3.6,1.1 \mathrm{~Hz}, 1 \mathrm{H}), 5.68(\mathrm{~s}, 1 \mathrm{H}), 5.35(\mathrm{~s}$, 1H). ${ }^{13} \mathrm{C}\left\{{ }^{1} \mathrm{H}\right\}$ NMR (100 MHz, $\left.\mathrm{CDCl}_{3}\right)$ 196.4, 145.2, 144.0, 142.7, 137.7, 137.3, 132.6, 130.22, 130.15, 128.4, 128.3, 127.5, 126.8, 125.5, 115.1. IR $v(\mathrm{C}=\mathrm{O}) 1652 \mathrm{~cm}^{-1}$. HRMS calcd for $\mathrm{C}_{19} \mathrm{H}_{14} \mathrm{OS}$ 290.0765; found 290.0784, spectral accuracy $98.7 \%$.<smiles>C=C(c1ccc(C(=O)OC)cc1)c1cccs1</smiles>

1-(4-Methoxycarbonylphenyl)-1-(thiophen-2-yl)ethylene (4c). Prepared by the general procedure and purified on 5\% $\mathrm{AgNO}_{3}$ impregnated silica gel eluting with $2 \rightarrow 3 \%$ EtOAc in hexanes. Yield $30.4 \mathrm{mg}(62 \%)$ pale yellow oil. ${ }^{1} \mathrm{H} \mathrm{NMR}\left(400 \mathrm{MHz}, \mathrm{CDCl}_{3}\right) 8.04(\mathrm{dt}, J=8.6,1.9 \mathrm{~Hz}, 2 \mathrm{H}), 7.51$ $(\mathrm{dt}, J=8.6,1.9 \mathrm{~Hz}, 2 \mathrm{H}), 7.26(\mathrm{dd}, J=5.1,1.1 \mathrm{~Hz}, 1 \mathrm{H}), 6.99(\mathrm{dd}, J=5.1,3.6 \mathrm{~Hz}, 1 \mathrm{H}), 6.88(\mathrm{dd}, J$ 
= 3.6, $1.1 \mathrm{~Hz}, 1 \mathrm{H}), 5.65(\mathrm{~s}, 1 \mathrm{H}), 5.31(\mathrm{~s}, 1 \mathrm{H}), 3.94(\mathrm{~s}, 3 \mathrm{H}) .{ }^{13} \mathrm{C}\left\{{ }^{1} \mathrm{H}\right\} \mathrm{NMR}\left(100 \mathrm{MHz}, \mathrm{CDCl}_{3}\right)$ 167.0, 145.7, 144.0, 142.8, 129.9, 129.7, 128.4, 127.5, 126.7, 125.5, 115.0, 52.3. IR v(C=O) 1717 $\mathrm{cm}^{-1}$. HRMS calcd for $\mathrm{C}_{14} \mathrm{H}_{12} \mathrm{O}_{2} \mathrm{~S} 244.0558$; found 244.0554, spectral accuracy $99.7 \%$.<smiles>C=C(c1ccc(C(=O)N2CCOCC2)cc1)c1cccs1</smiles>

1-(4-Morpholinylcarbonylphenyl)-1-(thiophen-2-yl)ethylene (4d). Prepared by the general procedure and purified on silica eluting with 5:1 hexanes:EtOAc $\rightarrow 5 \%$ MeCN in 2:1 hexanes:EtOAc. Yield $40.7 \mathrm{mg}(68 \%)$ off-white solid. ${ }^{1} \mathrm{H}$ NMR $\left(400 \mathrm{MHz}, \mathrm{CDCl}_{3}\right) 8.37$ (dt, $J=$ 8.4, $1.9 \mathrm{~Hz}, 2 \mathrm{H}), 7.41(\mathrm{dt}, J-8.4,1.9 \mathrm{~Hz}, 2 \mathrm{H}), 7.26(\mathrm{dd}, J=5.1,1.1 \mathrm{~Hz}, 1 \mathrm{H}), 6.98(\mathrm{dd}, J=5.1$, $3.6 \mathrm{~Hz}, 1 \mathrm{H}), 6.89(\mathrm{dd}, J=3.6,1.3 \mathrm{~Hz}, 1 \mathrm{H}), 5.62(\mathrm{~s}, 1 \mathrm{H}), 5.27(\mathrm{~s}, 1 \mathrm{H}), 3.72(\mathrm{br} \mathrm{s}, 8 \mathrm{H}) .{ }^{13} \mathrm{C}\left\{{ }^{1} \mathrm{H}\right\}$ NMR $\left(100 \mathrm{MHz}, \mathrm{CDCl}_{3}\right)$ 170.3, 144.2, 142.85, 142.78, 135.1, 128.6, 127.5, 127.3, 126.8, 125.5, 114.6, 67.1, 48.4 (br). IR $v(\mathrm{C}=\mathrm{O}) 1623 \mathrm{~cm}^{-1}$. HRMS calcd for $\mathrm{C}_{17} \mathrm{H}_{17} \mathrm{NO}_{2} \mathrm{~S}$ 299.0980; found 299.1004, spectral accuracy $99.1 \%$

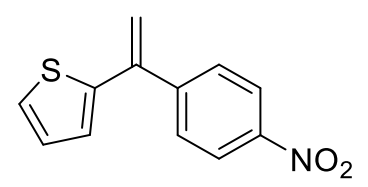

1-(4-Nitrophenyl)-1-(thiophen-2-yl)ethylene (4e). Prepared by the general method and purified on silica eluting with $10: 1 \rightarrow 3: 1$ hexanes:toluene. Yield $38.0 \mathrm{mg}(82 \%)$ yellow oil. ${ }^{1} \mathrm{H}$ NMR (400 $\left.\mathrm{MHz}, \mathrm{CDCl}_{3}\right) 8.93(\mathrm{dt}, J=8.9,2.0 \mathrm{~Hz}, 2 \mathrm{H}), 7.60(\mathrm{dt}, J=8.9,2.1 \mathrm{~Hz}, 2 \mathrm{H}), 7.29(\mathrm{dd}, J=5.1,1.1$ $\mathrm{Hz}, 1 \mathrm{H}), 7.01(\mathrm{dd}, J=5.1,3.6 \mathrm{~Hz}, 1 \mathrm{H}), 6.87(\mathrm{dd}, J=3.6,1.1 \mathrm{~Hz}, 1 \mathrm{H}), 5.72(\mathrm{~s}, 1 \mathrm{H}), 5.36(\mathrm{~s}, 1 \mathrm{H})$. ${ }^{13} \mathrm{C}\left\{{ }^{1} \mathrm{H}\right\} \mathrm{NMR}\left(100 \mathrm{MHz}, \mathrm{CDCl}_{3}\right) 147.7,147.6,143.3,141.8,129.3,127.6,126.9,125.9,123.7$, 116.2. IR $v\left(\mathrm{NO}_{2}\right)$ 1513, $1342 \mathrm{~cm}^{-1}$. HRMS calcd for $\mathrm{C}_{12} \mathrm{H}_{9} \mathrm{NO}_{2} \mathrm{~S}$ 231.0354; found 231.0380, spectral accuracy $99.4 \%$.<smiles>C=C(c1ccc(C)c([N+](=O)[O-])c1)c1cccs1</smiles>

1-(4-Methyl-3-nitrophenyl)-1-(thiophen-2-yl)ethylene (4f). Prepared by the general method and purified on silica eluting with 10:1 $\rightarrow 3: 1$ hexanes:toluene. Yield $43.8 \mathrm{mg}(89 \%)$ pale yellow oil. ${ }^{1} \mathrm{H}$ NMR $\left(400 \mathrm{MHz}, \mathrm{CDCl}_{3}\right) 8.05(\mathrm{~d}, J=2.1 \mathrm{~Hz}, 1 \mathrm{H}), 7.57(\mathrm{dd}, J=7.9,1.9 \mathrm{~Hz}, 1 \mathrm{H}), 7.34(\mathrm{~d}, J=7.9$ $\mathrm{Hz}, 1 \mathrm{H}), 7.28(\mathrm{dd}, J=5.3,1.1 \mathrm{~Hz}, 1 \mathrm{H}), 7.00(\mathrm{dd}, J=5.1,3.6 \mathrm{~Hz}, 1 \mathrm{H}), 6.88(\mathrm{dd}, J=3.6,1.1 \mathrm{~Hz}$, $1 \mathrm{H}), 5.65(\mathrm{~s}, 1 \mathrm{H}), 5.31(\mathrm{~s}, 1 \mathrm{H}), 2.63(\mathrm{~s}, 3 \mathrm{H}) .{ }^{13} \mathrm{C}\left\{{ }^{1} \mathrm{H}\right\} \mathrm{NMR}\left(100 \mathrm{MHz}, \mathrm{CDCl}_{3}\right)$ 149.3, 143.6, 141.3, $140.3,133.3,132.78,132.73,127.6,126.7,125.8,124.4,115.1,20.3 . \mathrm{IR} v\left(\mathrm{NO}_{2}\right) 1523,1344 \mathrm{~cm}^{-}$ ${ }^{1}$. HRMS calcd for $\mathrm{C}_{13} \mathrm{H}_{11} \mathrm{NO}_{2} \mathrm{~S} 245.0510$; found 245.0529 , spectral accuracy $98.9 \%$.

Computational Methods. All calculations were performed using the Gaussian 09 software suite. ${ }^{21}$ Structures were optimized at the $\mathrm{m}^{2} \mathrm{l}^{22} / \mathrm{def} 2-\mathrm{SVP}^{23}$ with associated ECP for $\mathrm{Pd}^{24}$ level of theory 
and confirmed to be local minima or transition states by the presence of 0 or 1 imaginary frequencies respectively. For transition state structures the normal mode vibration corresponding to the imaginary frequency involved the motion of the correct atom(s) along the reaction coordinate in all cases. Energies were calculated at the M06-L/def2-TZVP ${ }^{23}$ level of theory on the m061/def2SVP optimized structures and incorporated solvation effects using the polarizable continuum model with toluene solvent ${ }^{25}$. Zero-point and thermal corrections were taken from the m061/def2SVP frequency calculations. 


\section{Additional flow reactor and equipment details}

A photo of the reactor setup is shown in Figure S1. All tubes were either 1/16" O.D., $0.5 \mathrm{~mm}$ I.D. PFA or 1/16" OD, $0.75 \mathrm{~mm}$ ID 316 stainless steel (316 SS), and connected to a 20 gauge, 6" 316 SS septum piercing needle to allow introduction of the diazo solution to the reaction flask under Ar. PEEK fittings and parts were purchased from UpChurch Scientific. The stainless steel packed bed reactor was cut to length in house from 1/4" OD, $3 \mathrm{~mm}$ ID 316 SS tubing purchased from McMaster Carr and freshly packed with $\mathrm{MnO}_{2}$ before each experiment then sealed with HPLC end fittings purchased from VICI Valco. For experiments requiring diazo generation at $0{ }^{\circ} \mathrm{C}$ the SS packed bed reactor was submerged in an ice water bath.

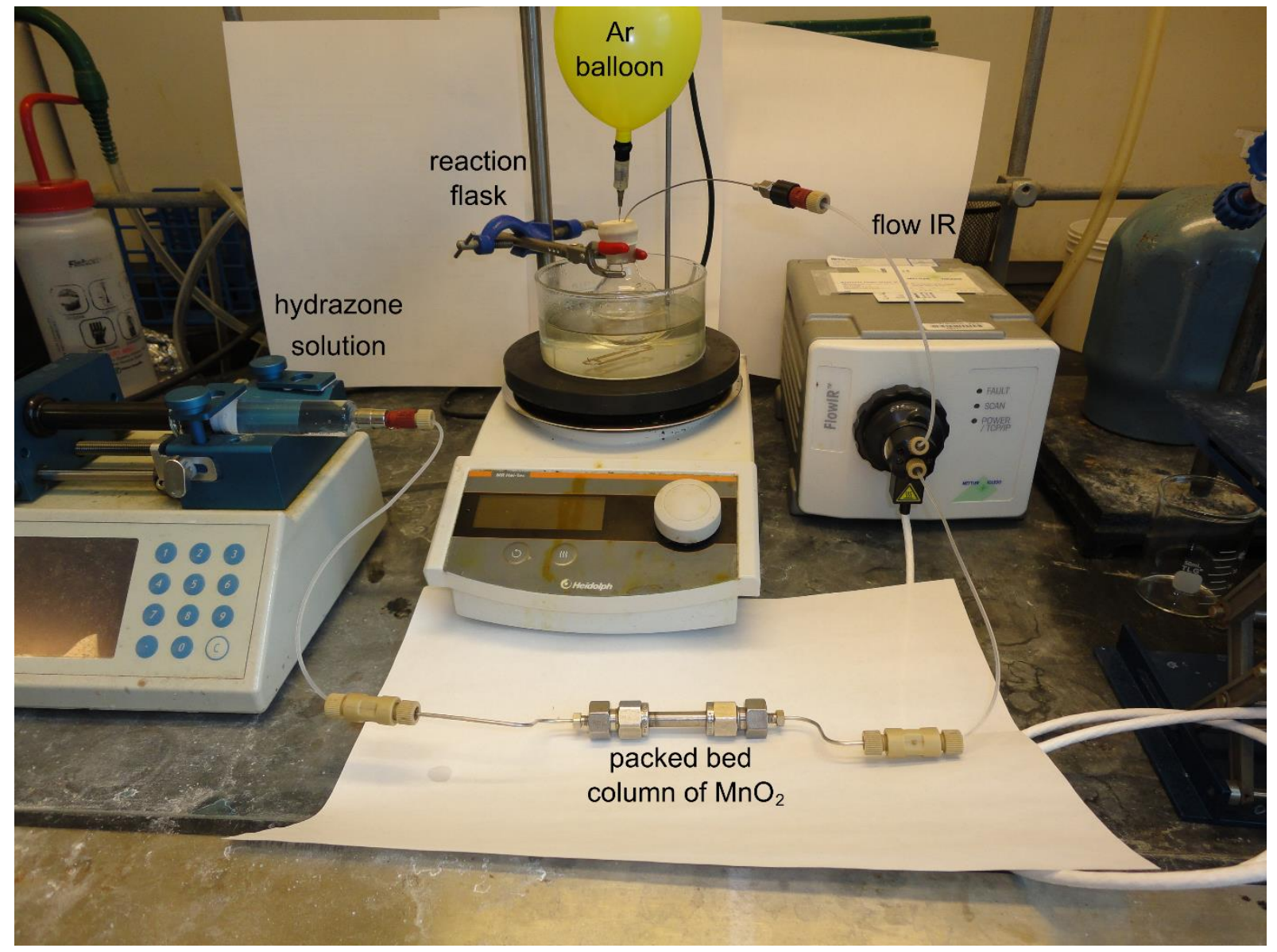

Figure S1. Photo of experimental set up. 


\section{Aryl bromide-diazo cross-coupling optimization}

Initial optimization was performed using stabilized ethyl 2-diazopropoanate (Table S1). Decreasing the palladium loading relative to the literature report had detrimental affect (entry 2). Changing between XPhos and SPhos had little effect (entry 3). Switching from [Pd(allyl)Cl $]_{2}$ to $\mathrm{Pd}(\mathrm{OAc})_{2}$ resulted in marginal improvement (entry 4). Addition of the diazo over 3 (entry 6) or 15 min (entry 4) further improved yields but not to satisfactory levels, although allowing a further decrease the palladium loading to $2.5 \%$ (entry 8 ) with negligible impact relative to 5\% loading. Examination of pre-ligated precatalysts showed the Buchwald G2 type precatalysts were ineffective (entry 9), but $\mathrm{Pd}(\mathrm{XPhos})($ allyl)Cl (entry 10) and $\mathrm{Pd}(\mathrm{XPhos})($ cinnamyl)Cl (entry 11) were active precatalyts. Inclusion of one additional equivalent of ligand was necessary for high yield (entry 13) and had greater impact that doubling the precatalyst loading (entry 12), suggesting that ligand destruction is the most significant source of catalyst death. Finally, increasing to $3.5 \%$ from $2.5 \%$ catalyst loading led to near quantitative yield (entry 14) for the reaction with the stabilized diazo compound. When changing to the less stable, alpha aryl diazo reagent, a decrease in yield was observed (entry 15), requiring an increase in the equivalency from 1.5 to 2.0 eq. to maintain high yield for reactions with the non-stabilized diazo reagents (entry 16). 
Table S1. Optimization of the aryl bromide-diazo cross-coupling reactions

\begin{tabular}{|c|c|c|c|c|c|c|c|}
\hline & $\begin{array}{l}\mathrm{PhBr} \quad \frac{{ }^{i} \mathrm{Pr}_{2}}{\mathrm{dia}} \\
\mathrm{R}=\mathrm{CO}_{2} \mathrm{Et}, \mathrm{Ph}\end{array}$ & $\begin{array}{l}\mathrm{Pd} / \mathrm{L} \\
\mathrm{NH}, 80^{\circ} \\
\mathrm{zo} 1 \text { or } 2\end{array}$ & $\mathrm{Ph}$ & & 1 & $\mathrm{Ph}_{2}^{\mathrm{N}_{2}}$ & \\
\hline Entry & Pd precatalyst & $\% \mathrm{Pd}$ & Ligand (\%) & Diazo & $\begin{array}{c}\text { Diazo } \\
\text { eq. }\end{array}$ & $\begin{array}{c}\text { Addition } \\
\text { time (min) }\end{array}$ & Yield $^{a}$ \\
\hline 1 & {$[\mathrm{Pd}(\text { allyl }) \mathrm{Cl}]_{2}$} & 10 & XPhos (10\%) & $\mathbf{1}$ & 1.5 & $\mathrm{n} / \mathrm{a}$ & $86(\mathrm{lit})^{26}$ \\
\hline 2 & {$[\mathrm{Pd}(\text { allyl }) \mathrm{Cl}]_{2}$} & 5 & XPhos (10\%) & 1 & 1.5 & $\mathrm{n} / \mathrm{a}$ & 53 \\
\hline 3 & {$[\mathrm{Pd}(\text { allyl }) \mathrm{Cl}]_{2}$} & 5 & SPhos (10\%) & 1 & 1.5 & $\mathrm{n} / \mathrm{a}$ & 47 \\
\hline 4 & $\mathrm{Pd}(\mathrm{OAc})_{2}$ & 5 & XPhos $(10 \%)$ & 1 & 1.5 & $\mathrm{n} / \mathrm{a}$ & 66 \\
\hline 5 & $\mathrm{Pd}(\mathrm{OAc})_{2}$ & 5 & XPhos (10\%) & 1 & 1.25 & 3 & 69 \\
\hline 6 & $\mathrm{Pd}(\mathrm{OAc})_{2}$ & 5 & XPhos $(10 \%)$ & 1 & 1.25 & 15 & 74 \\
\hline 7 & $\mathrm{Pd}(\mathrm{OAc})_{2}$ & 5 & XPhos (10\%) & 1 & 1.5 & 15 & 76 \\
\hline 8 & $\mathrm{Pd}(\mathrm{OAc})_{2}$ & 2.5 & XPhos (5\%) & 1 & 1.5 & 15 & 63 \\
\hline 9 & Pd-XPhos G2 precat. & 2.5 & $\mathrm{n} / \mathrm{a}$ & 1 & 1.5 & 15 & 27 \\
\hline 10 & $\mathrm{Pd}(\mathrm{XPhos})$ (allyl)Cl & 2.5 & $\mathrm{n} / \mathrm{a}$ & 1 & 1.5 & 15 & 54 \\
\hline 11 & $\mathrm{Pd}(\mathrm{XPhos})$ (cinnamyl)Cl & 2.5 & $\mathrm{n} / \mathrm{a}$ & 1 & 1.5 & 15 & 46 \\
\hline 12 & $\mathrm{Pd}(\mathrm{XPhos})($ allyl $) \mathrm{Cl}$ & 5 & $\mathrm{n} / \mathrm{a}$ & 1 & 1.5 & 15 & 70 \\
\hline 13 & $\operatorname{Pd}(\mathrm{XPhos})($ allyl)Cl & 2.5 & XPhos $(2.5 \%)$ & 1 & 1.5 & 15 & 77 \\
\hline 14 & $\mathrm{Pd}(\mathrm{XPhos})$ (allyl)Cl & 3.5 & XPhos $(3.5 \%)$ & $\mathbf{1}$ & 1.5 & 15 & $>95,\left(77^{b}\right)$ \\
\hline 15 & $\mathrm{Pd}(\mathrm{XPhos})$ (allyl)Cl & 3.5 & XPhos $(3.5 \%)$ & 2 & 1.5 & 15 & $64^{b}$ \\
\hline 16 & $\mathrm{Pd}(\mathrm{XPhos})($ allyl)Cl & 3.5 & XPhos $(3.5 \%)$ & 2 & 2 & 20 & $90^{b}$ \\
\hline
\end{tabular}

\section{Robustness of diazo generation over $\mathrm{MnO}_{2}$}

The literature conditions for oxidation of hydrazones to diazo compounds over $\mathrm{MnO}_{2}$ used flow rates of $0.5 \mathrm{~mL} / \mathrm{min}$ and DCM as solvent, with DIPEA as the organic base. ${ }^{8}$ To enable compatibility with the conditions needed for the diazo-aryl halide cross coupling (toluene, ${ }^{i} \operatorname{Pr}_{2} \mathrm{NH}$, slower flow rate) the robustness of the generation of 2-diazoacetophenone from acetophenone hydrazone was investigated using an esterification quench with benzoic acid for quantification of diazo 'yield' (Scheme S1). 
Scheme S1. Examination of diazo generation from acetophenone hydrazone using a quench with benzoic acid for quantification of diazo 'yield'

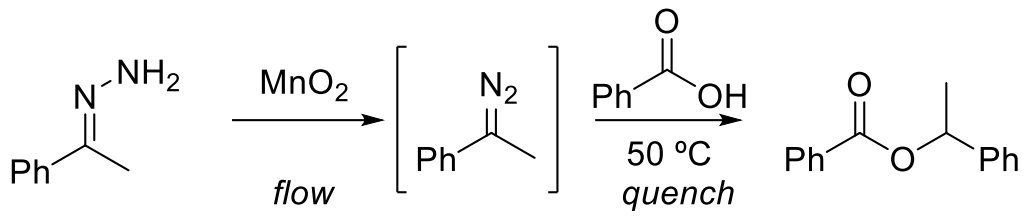

A Design of Experiments (DoE) 3 factor, 2-level factorial design was executed examining the effect of hydrazone concentration $(0.05-0.1 \mathrm{M})$, flow rate through the $\mathrm{MnO}_{2}$ packed bed $(0.15-$ $0.35 \mathrm{~mL} / \mathrm{min}$ ) and equivalence of ${ }^{i} \operatorname{Pr}_{2} \mathrm{NH}$ (1-2 eq). The affect of increased base equivalence always improved diazo yield, so 2 eq. of ${ }^{i} \operatorname{Pr}_{2} \mathrm{NH}$ was selected and additional experiments to complete a central composite design in order to generate a response surface for the factors of hydrazone concentration and flow rate were completed. The response surface is shown in Figure S2. The effect of hydrazone concentration was relatively minor, while the effect of increased flow rate resulted in a slight increase in diazo yield. Flow rates of $0.35 \mathrm{~mL} / \mathrm{min}$ were therefore selected and hydrazone concentration was modified to achieve desired molar addition rates for cross-coupling reactions.

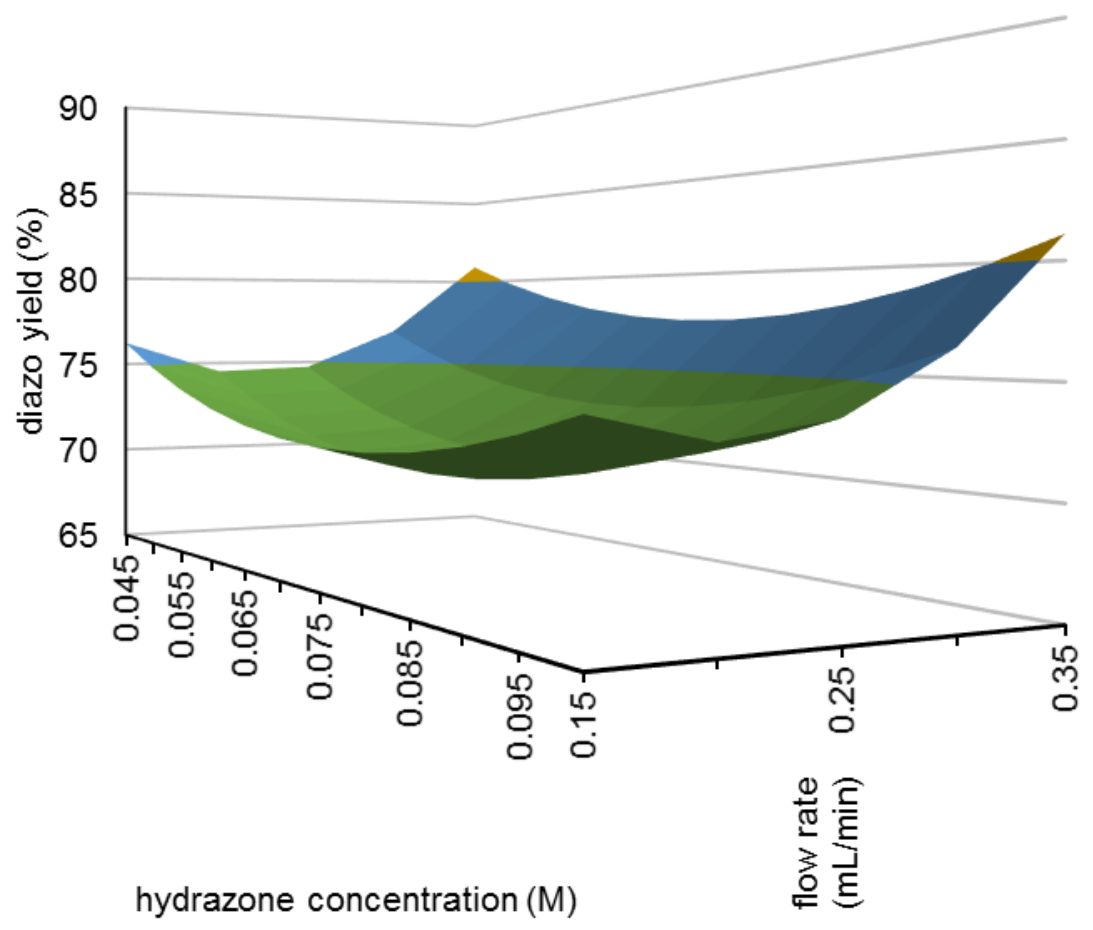

Figure S2. Response surface of 2-diazoacetophenone yield as a function of acetophenone hydrazone concentration in toluene and flow rate through a $3 \times 50 \mathrm{~mm}$ packed bed of $\mathrm{MnO}_{2}$ in the presence of 2 eq. of ${ }^{i} \mathrm{Pr}_{2} \mathrm{NH}$. 


\section{Calculation of TOF from computed energy profiles}

In order to calculate turn over frequency (TOF) from an energy diagram, the energetic span model was applied. In this model, the energy separation between the turnover frequency determining transition state (TDTS, lowest energy intermediate) and turnover frequency determining intermediate (TDI, transition state that maximizes the energetic span) is used, corrected for the free energy of the net process if the TDTS precedes the TDI according to equation 1.27

$$
\begin{gathered}
\text { TOF }=\frac{k_{\mathrm{B}} T}{h} \mathrm{e}^{-\delta E / R T} \\
\delta E=\left\{\begin{array}{cl}
T_{\mathrm{TDTS}}-I_{\mathrm{TDI}} & \text { if TDTS follows TDI } \\
T_{\mathrm{TDTS}}-I_{\mathrm{TDI}}+\Delta G_{\mathrm{rxn}} & \text { if TDTS proceeds TDI }
\end{array}\right\}
\end{gathered}
$$

For this transformation it was found that the TDTS was oxidative addition of $\operatorname{Pd}(0)$ into the aryl chloride and the TDI was the intermediate following aryl group migration into the Pd-carbene. The energies used and calculated TOF for the three substrates are summarized in Table S2.

Table S2. Calculated energies of $\Delta G, E_{T D T S}, E_{T D I}$ and $\delta E$ used for the calculation of TOF presented in Table 1.

\begin{tabular}{ccccccc}
\hline $\mathrm{ArCl}$ & $\begin{array}{c}\Delta \mathrm{G} \\
(\mathrm{kcal} / \mathrm{mol})\end{array}$ & $\begin{array}{c}\mathrm{E}_{\mathrm{TDTS}} \\
(\mathrm{kcal} / \mathrm{mol})\end{array}$ & $\begin{array}{c}\mathrm{E}_{\mathrm{TDI}} \\
(\mathrm{kcal} / \mathrm{mol})\end{array}$ & $\begin{array}{c}\delta \mathrm{E} \\
(\mathrm{kcal} / \mathrm{mol})\end{array}$ & $\begin{array}{c}\text { TOF at T }= \\
373 \mathrm{~K}^{-1} \mathrm{~h}^{-1}\end{array}$ & relative TOF \\
\hline $\mathrm{PhCl}$ & -46.402 & 8.128 & -70.557 & 32.283 & $3.46 \times 10^{-3}$ & 1.0 \\
$4-\mathrm{CN}-\mathrm{PhCl}$ & -47.051 & 5.119 & -70.719 & 28.787 & $3.86 \times 10^{-1}$ & $1.1 \times 10^{2}$ \\
$4-\mathrm{OMe}-\mathrm{PhCl}$ & -46.806 & 10.915 & -70.297 & 34.406 & $1.97 \times 10^{-4}$ & $5.7 \times 10^{-2}$ \\
\hline
\end{tabular}

\section{Additional computational results not included in the manuscript}

The direct reaction of $\operatorname{Pd}(0)$ with the diazo compound exhibited much higher activation barriers than oxidative addition of $\operatorname{Pd}(0)$ into the $\mathrm{Ar}-\mathrm{X}$ bond, making direct reaction between $\operatorname{Pd}(0)$ and diazo in the presence of aryl halide unlikely (Figure S3). 


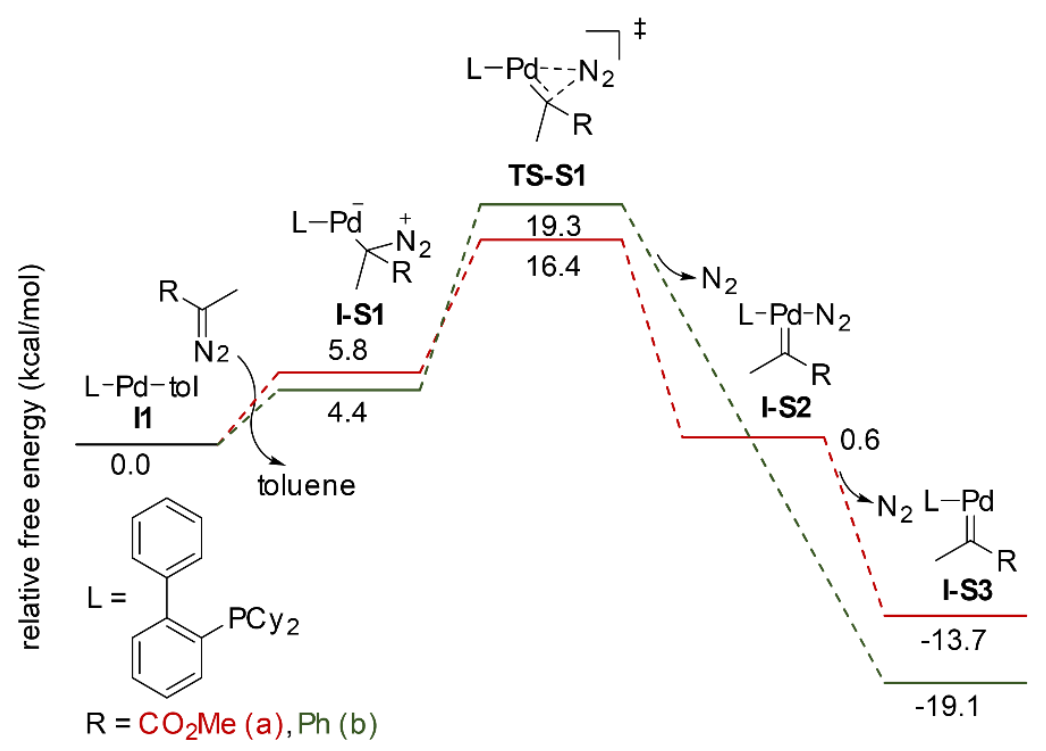

Figure S3. Energy profile for direct reaction of diazo compound with Pd(0); M06-L/def2-TZVP//M06L/def2-SVP level of theory.

Additional details of the oxidative addition omitted from the main manuscript are provided in Figure S4.

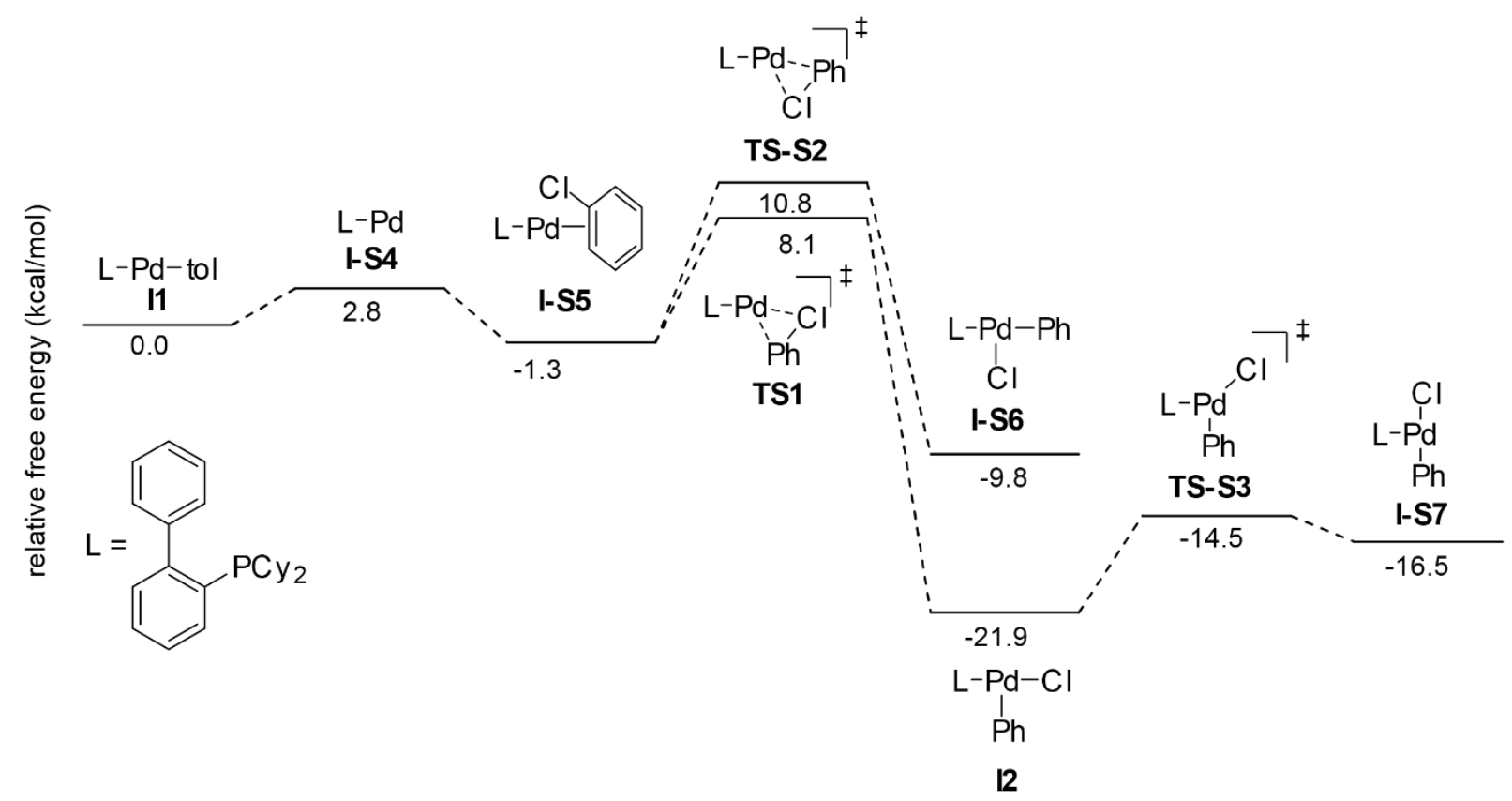

Figure S4. Energy profile for the oxidative addition; M06-L/def2-TZVP//M06-L/def2-SVP level of theory. 
7. Characterization data of hydrazones, diazo compounds and palladium precatalysts

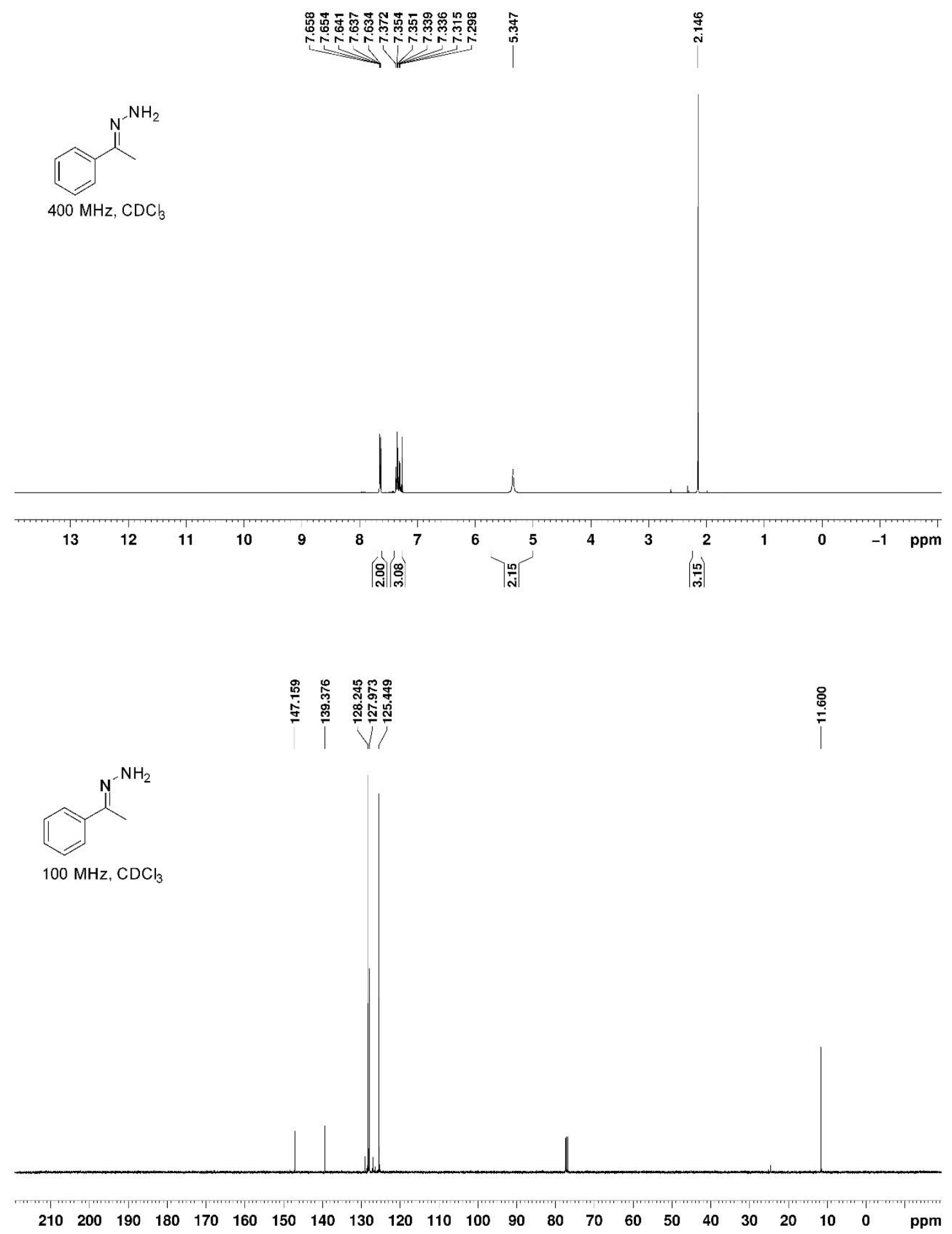



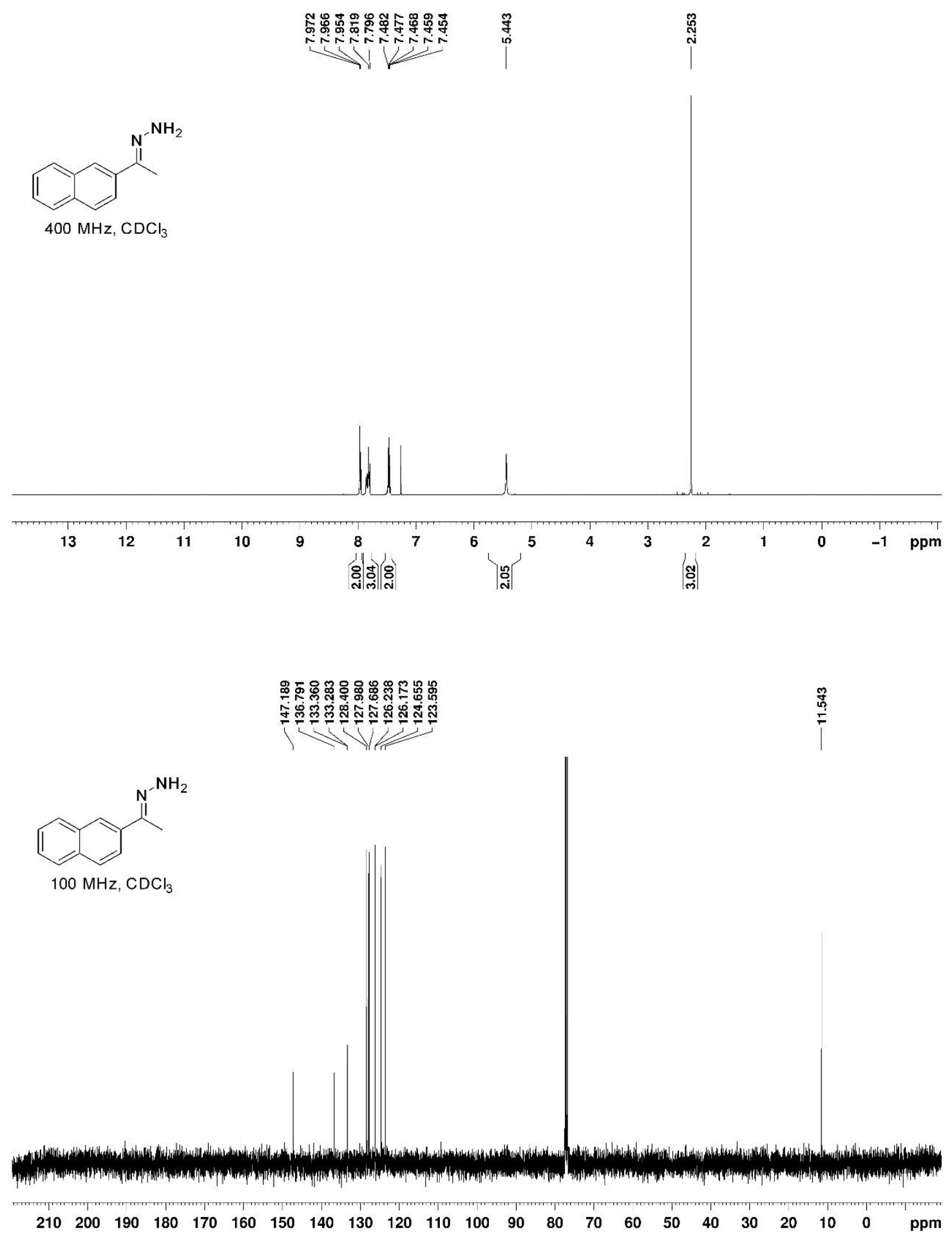

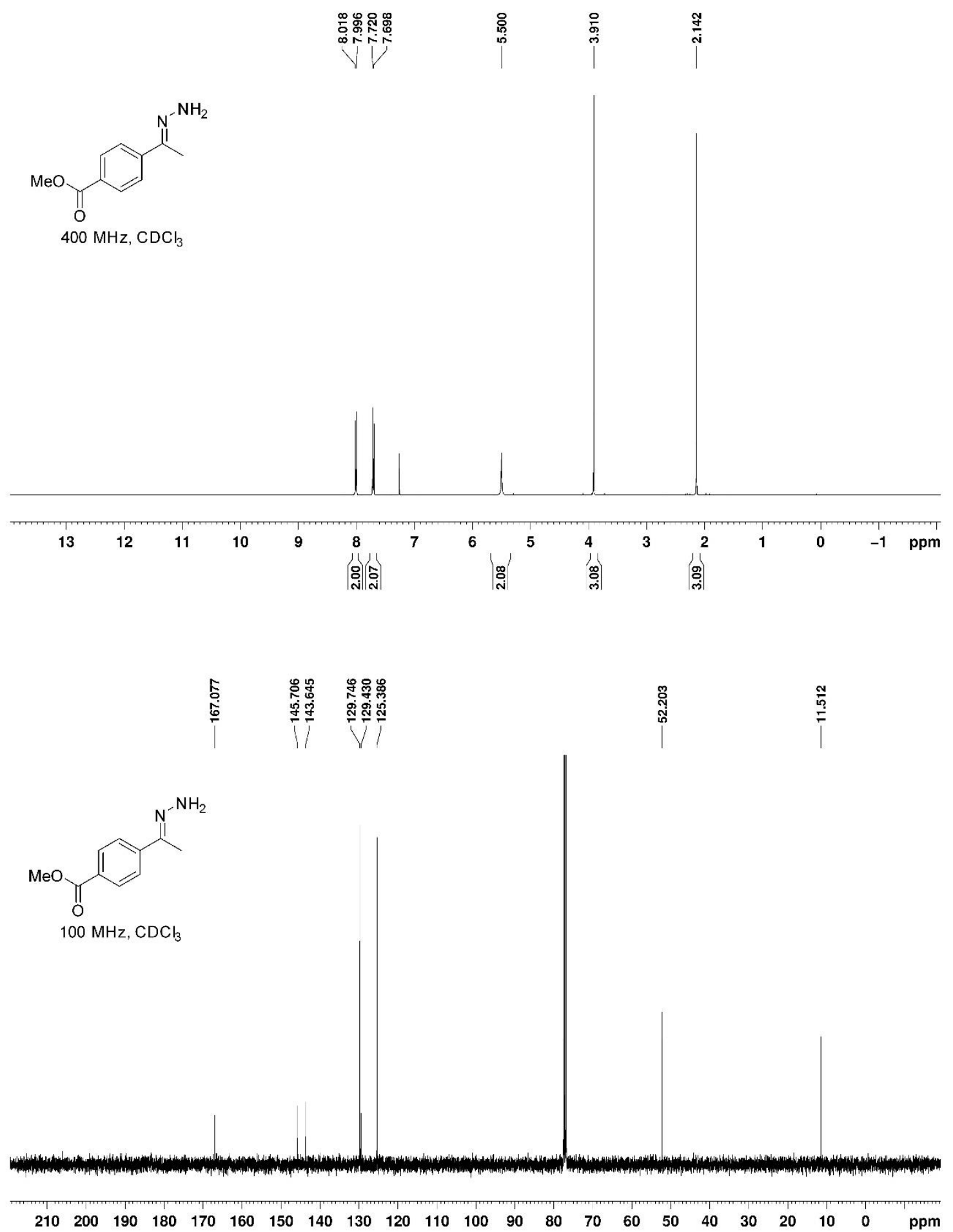

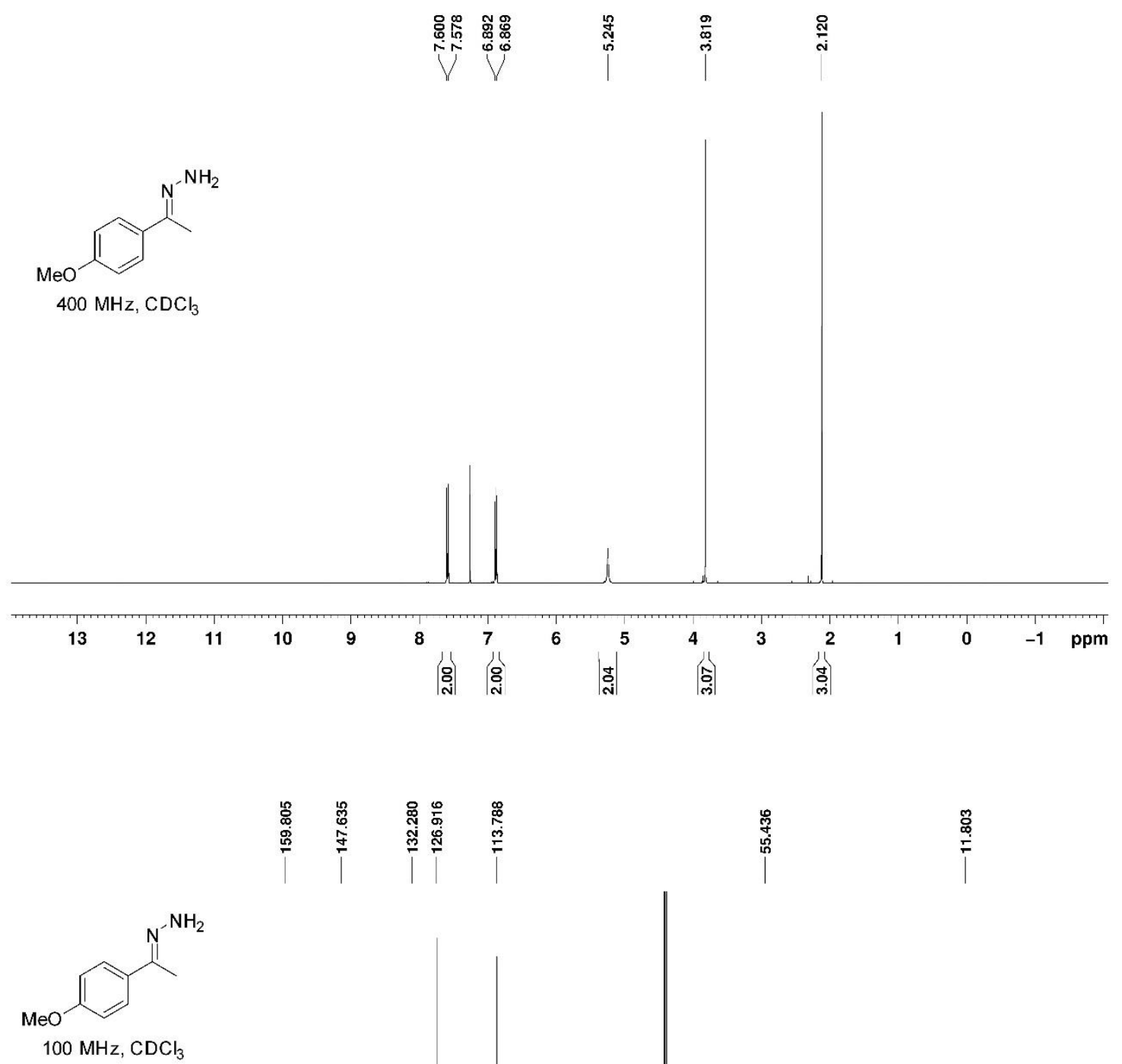

$100 \mathrm{MHz}, \mathrm{CDCl}_{3}$
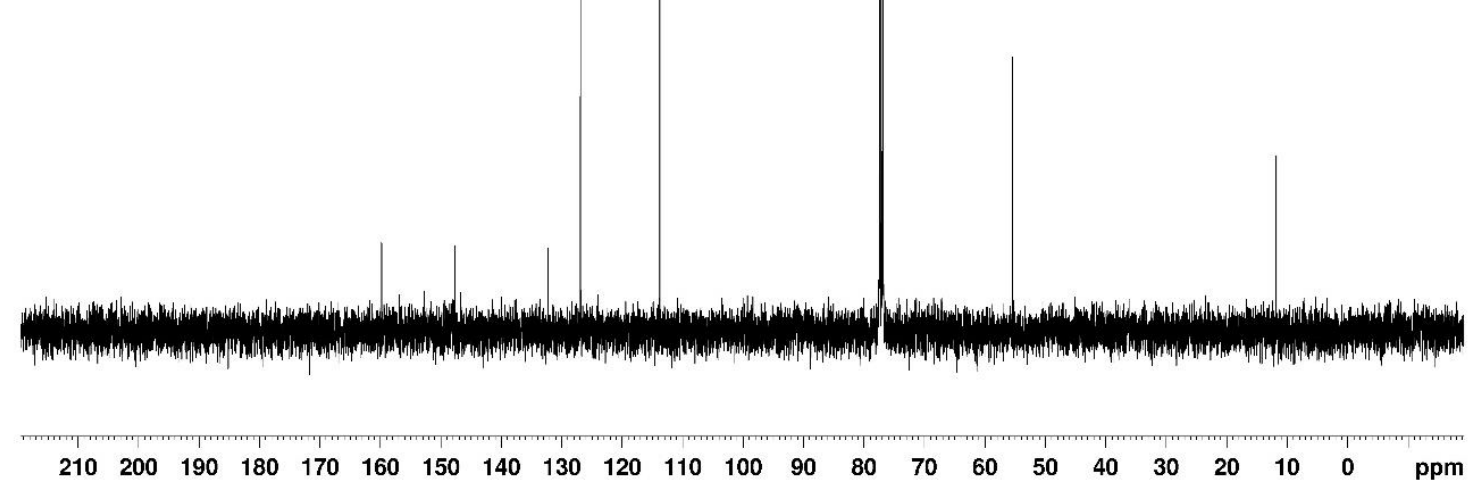


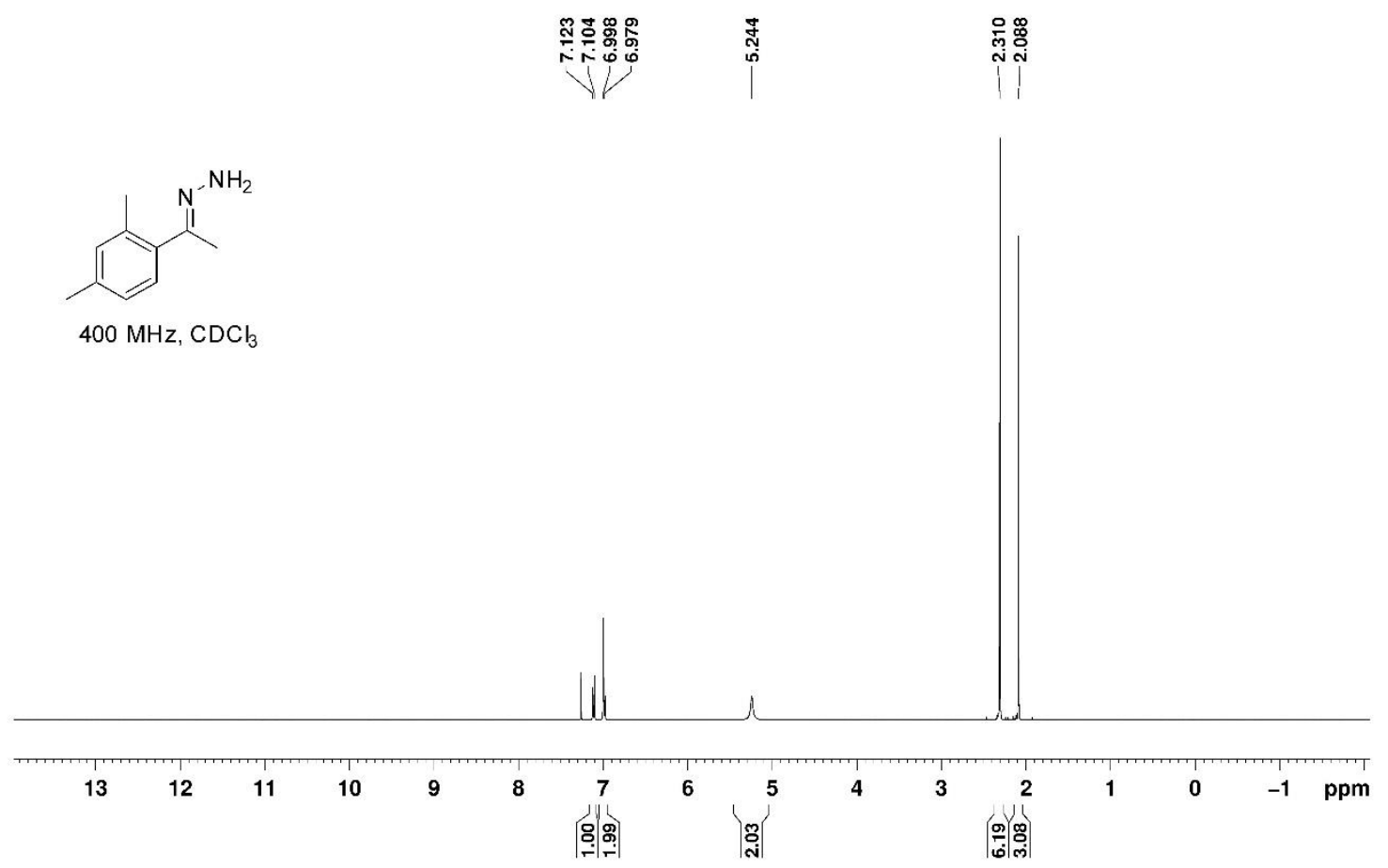

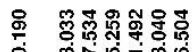

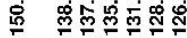

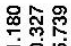

สंฝำ

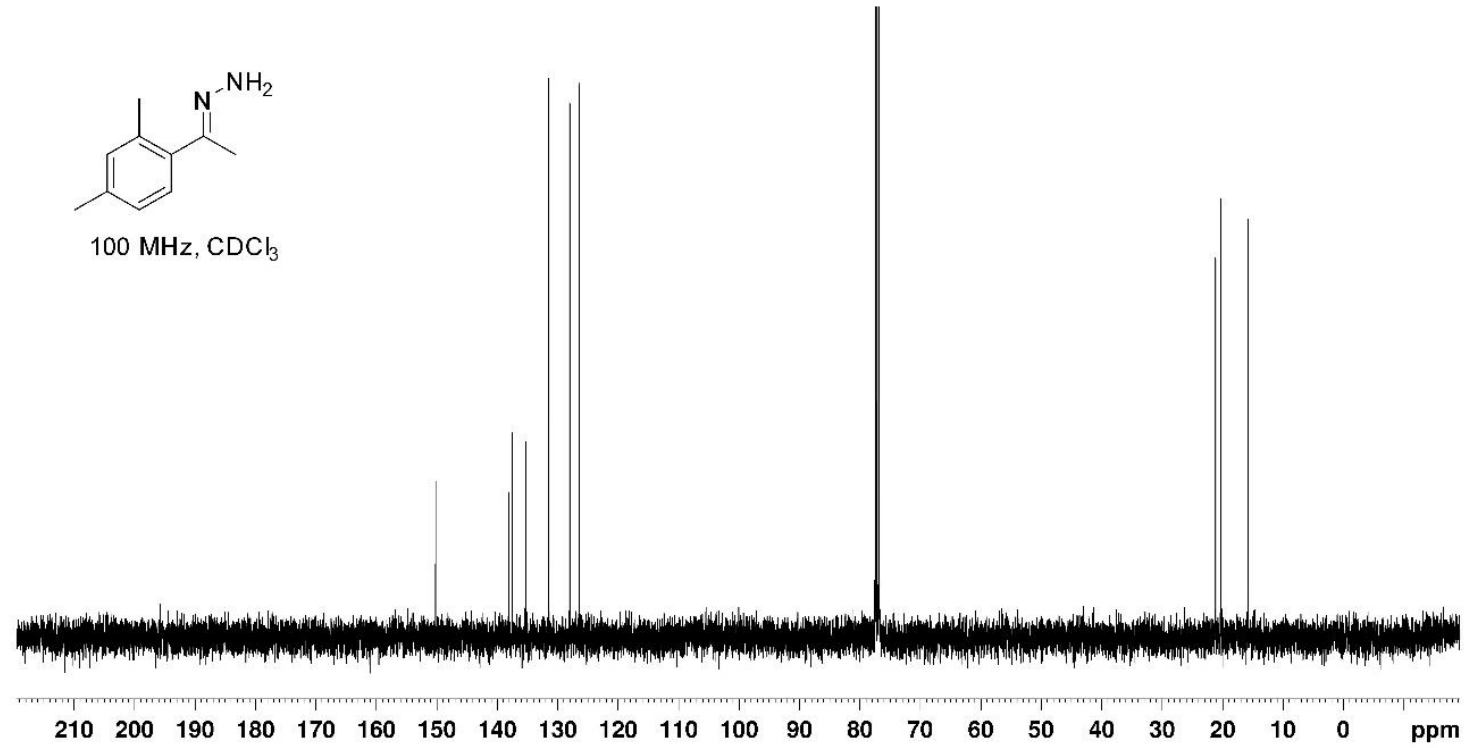



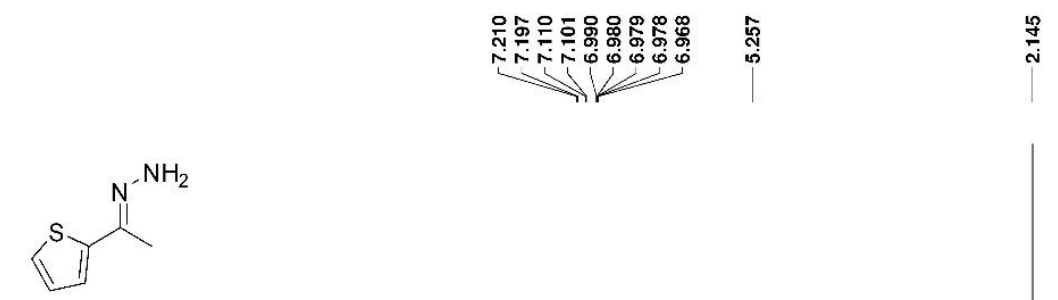

$400 \mathrm{MHz}, \mathrm{CDCl}_{3}$
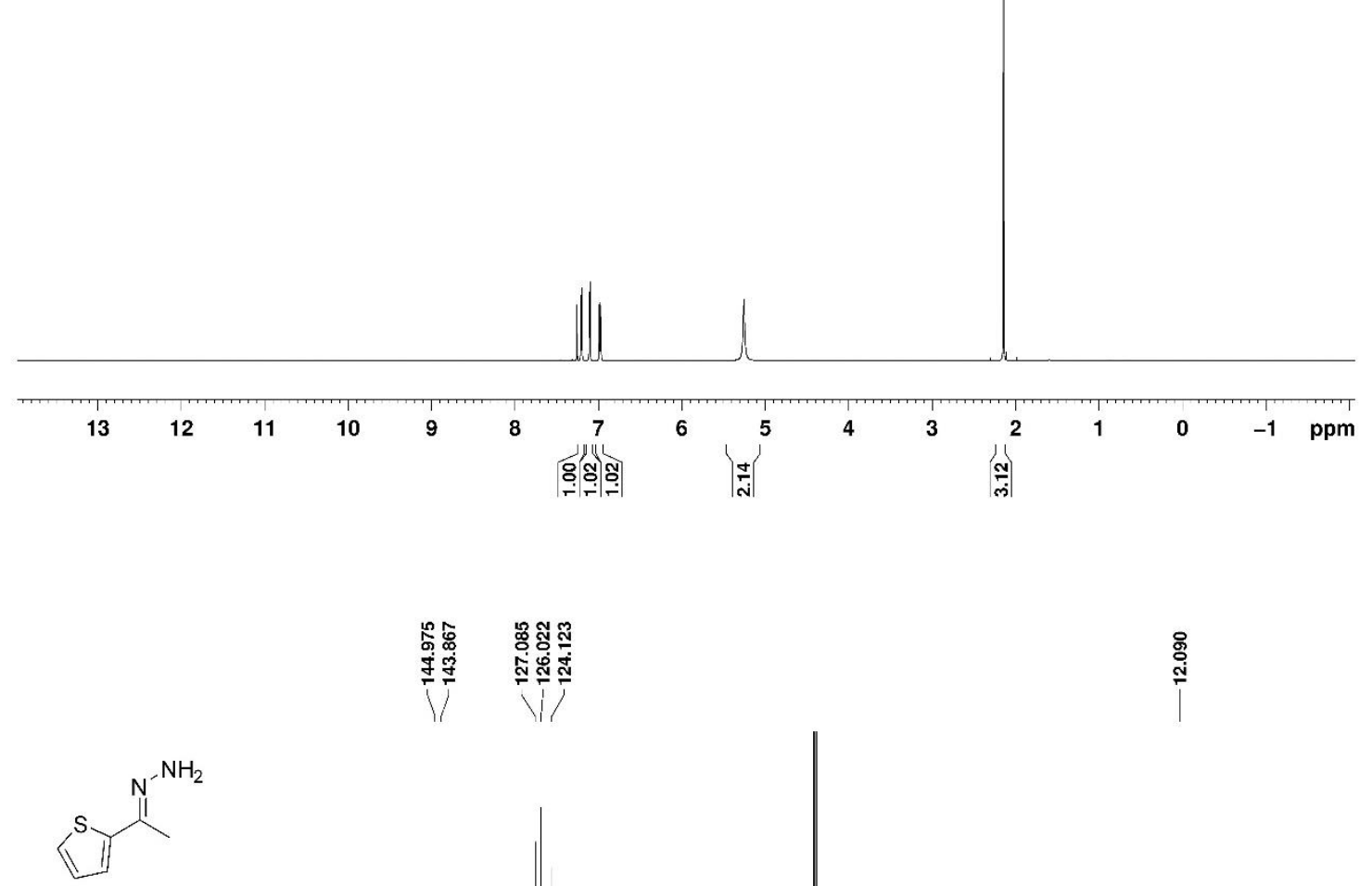

$100 \mathrm{MHz}, \mathrm{CDCl}_{3}$

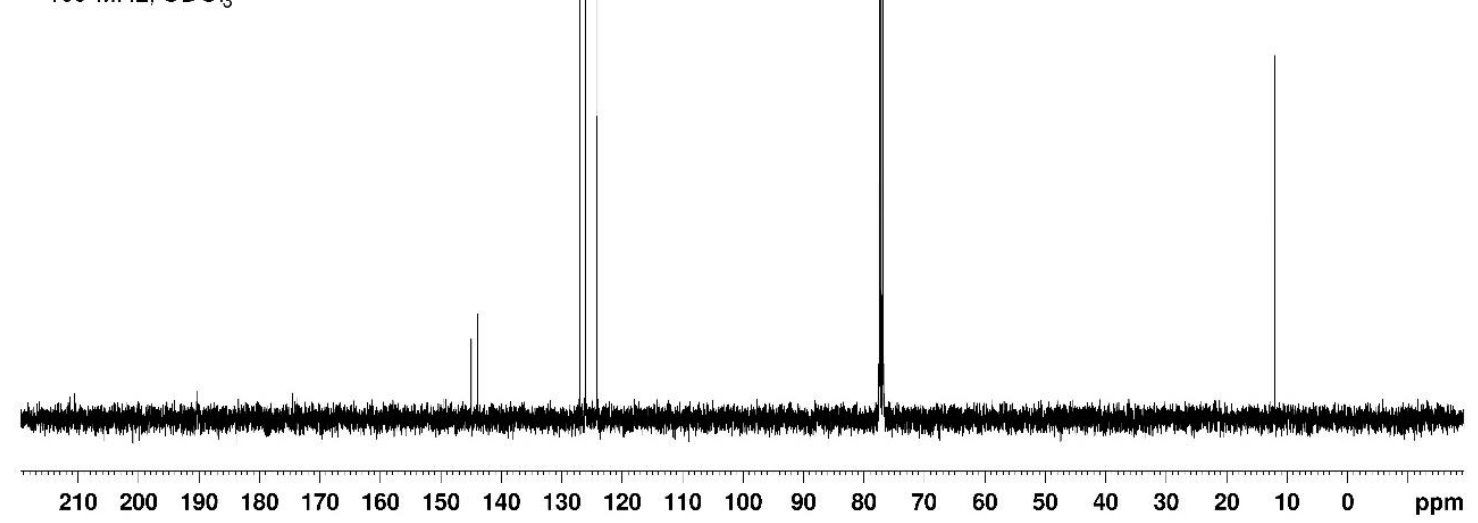




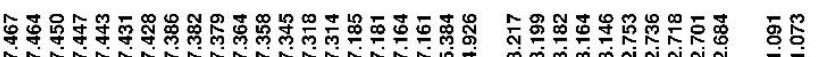

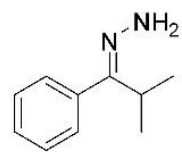

$400 \mathrm{MHz}, \mathrm{CDCl}_{3}$
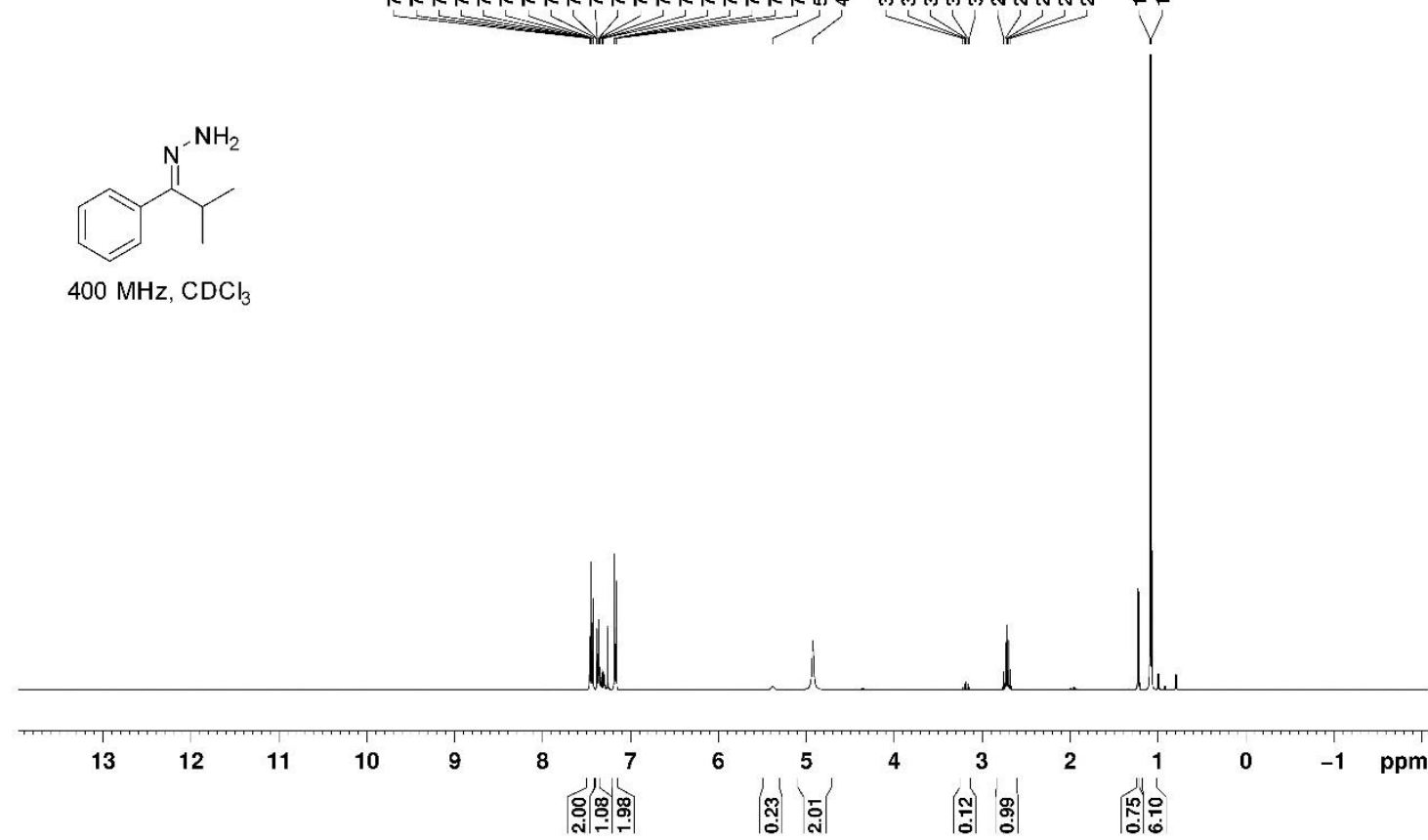

0
0
0

每

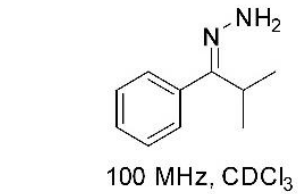

$100 \mathrm{MHz} \mathrm{CDCl}_{3}$
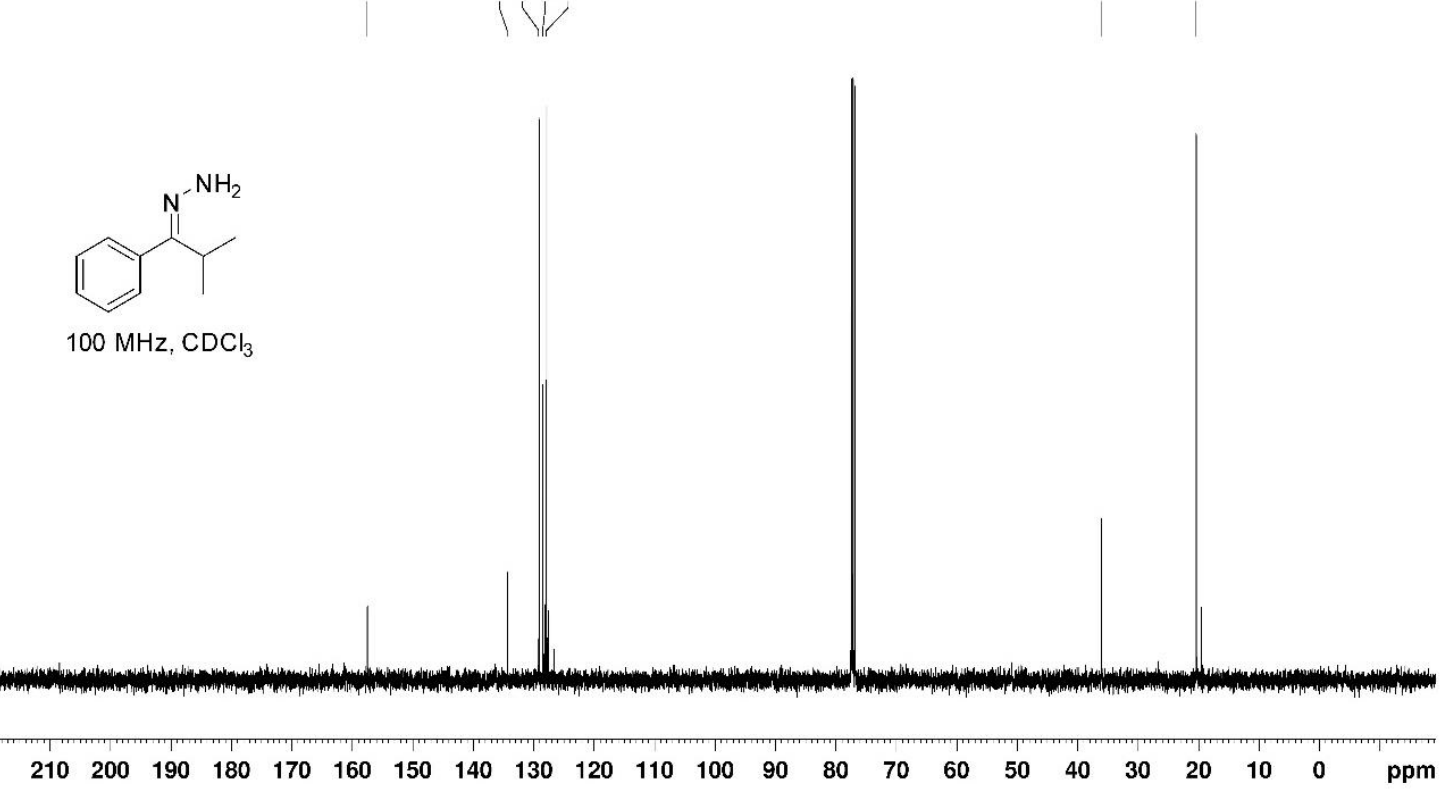


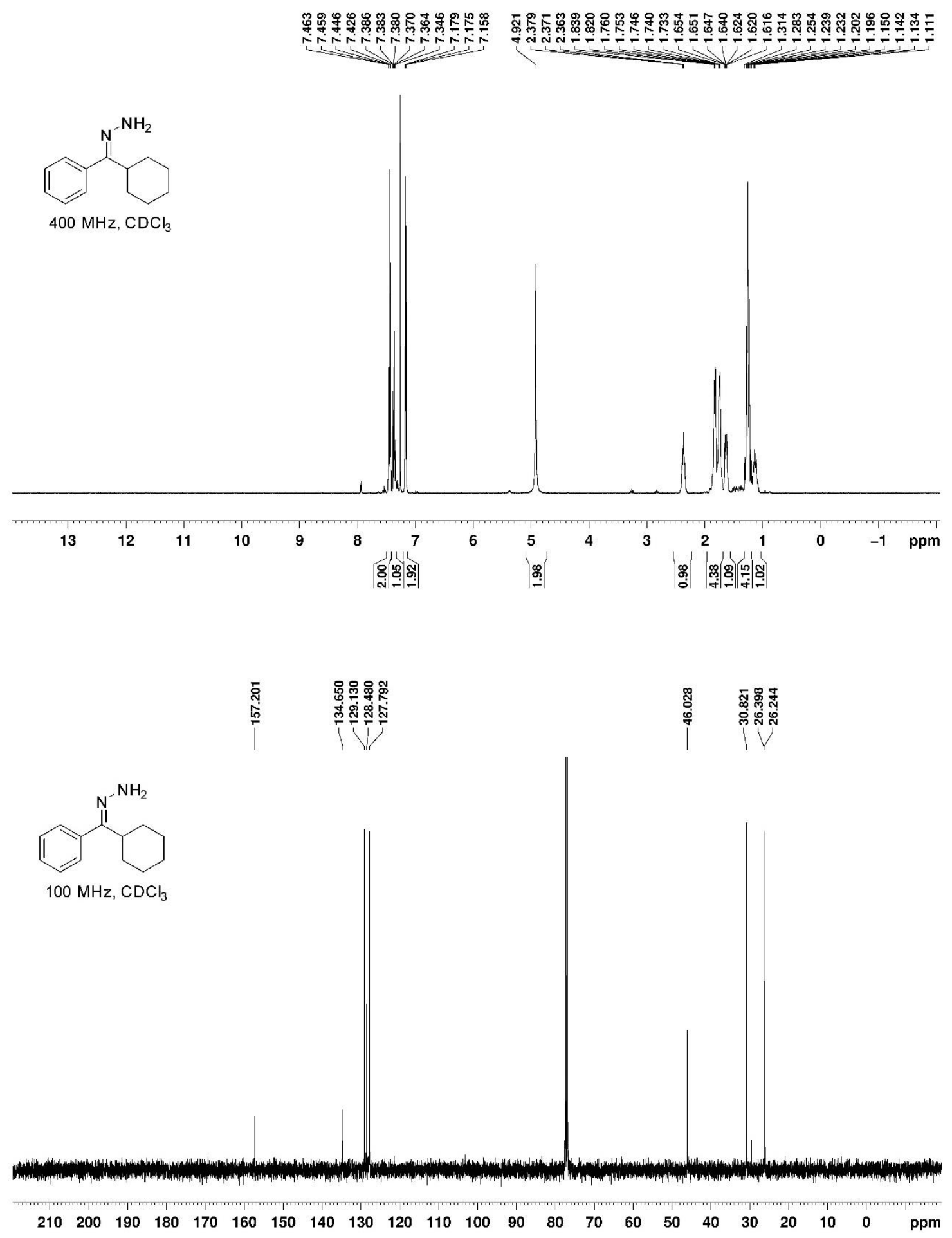




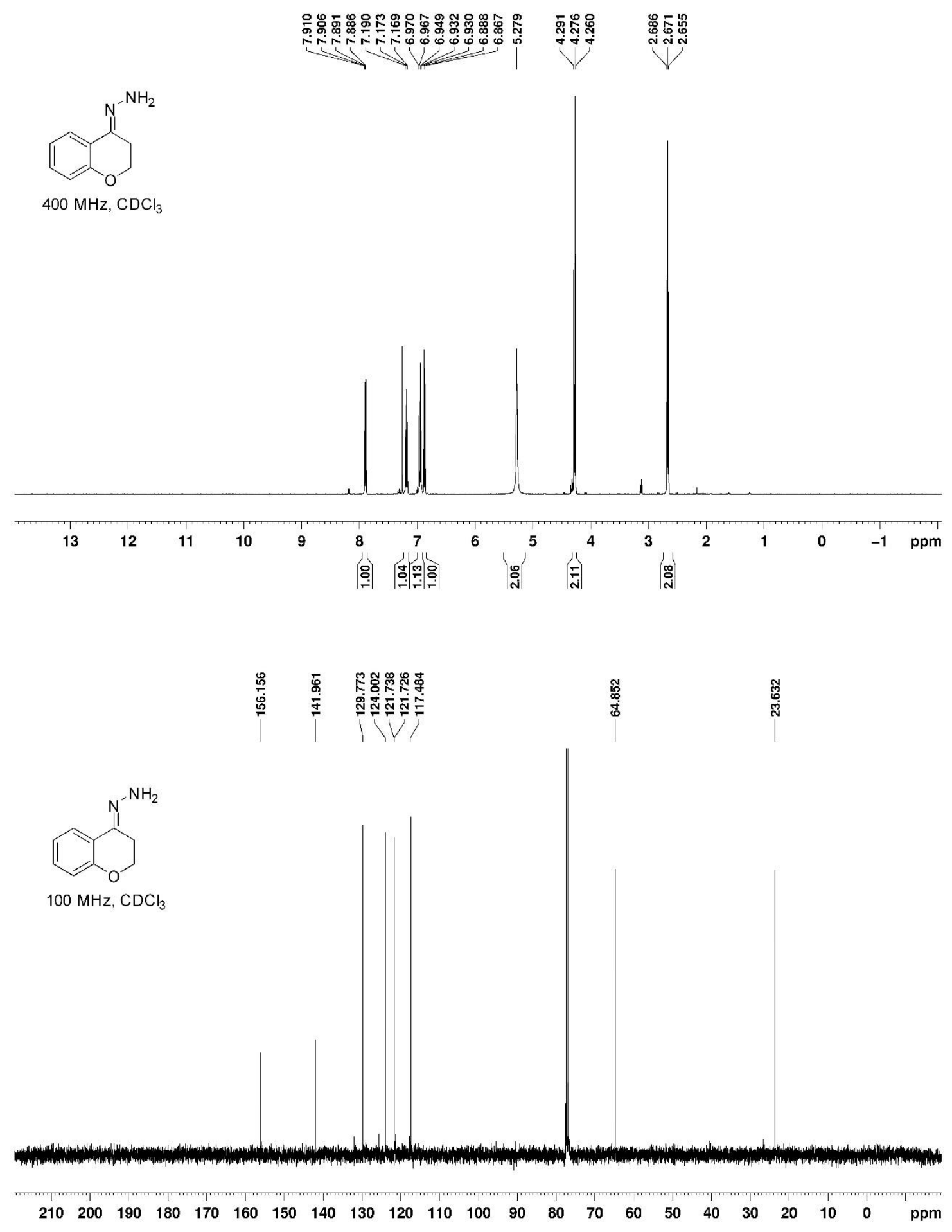




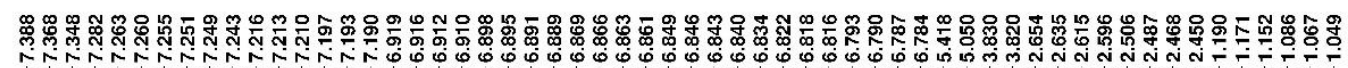

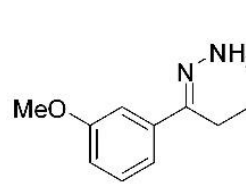

$400 \mathrm{MHz}, \mathrm{CDCl}_{3}$
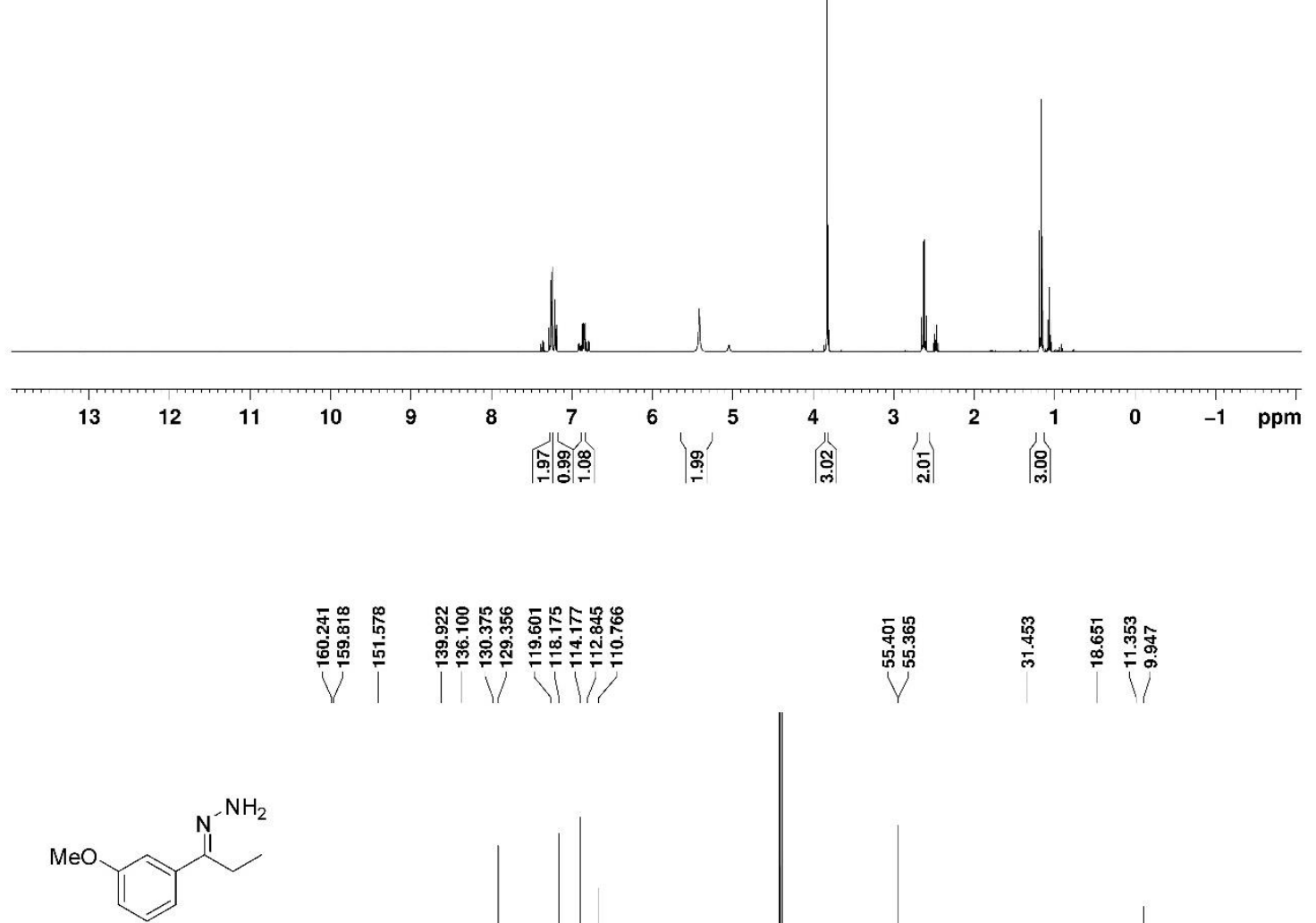

$100 \mathrm{MHz}, \mathrm{CDCl}_{3}$

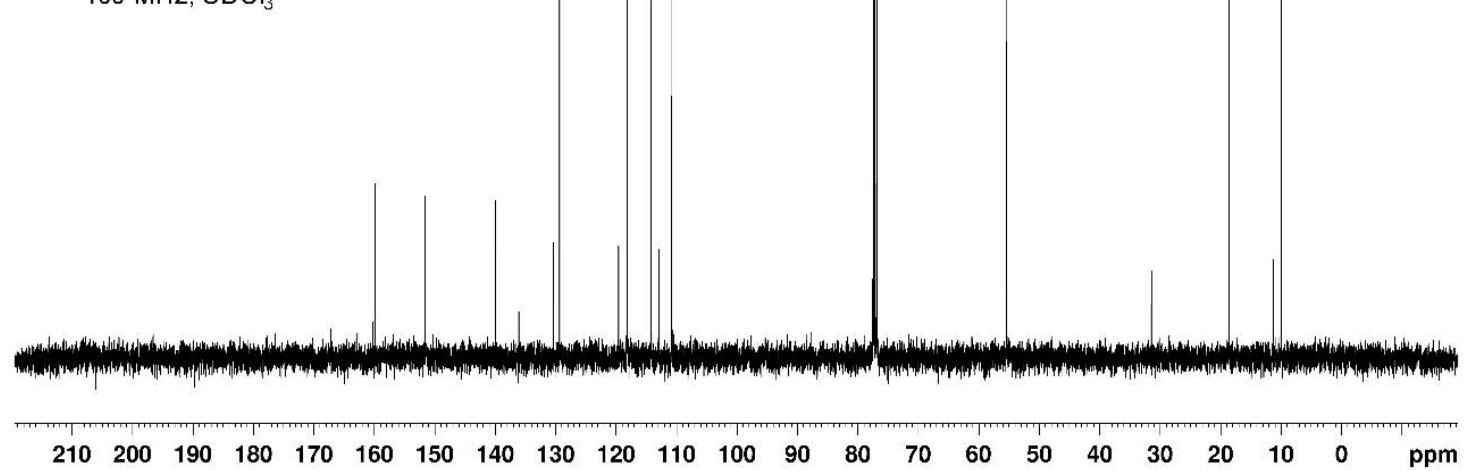




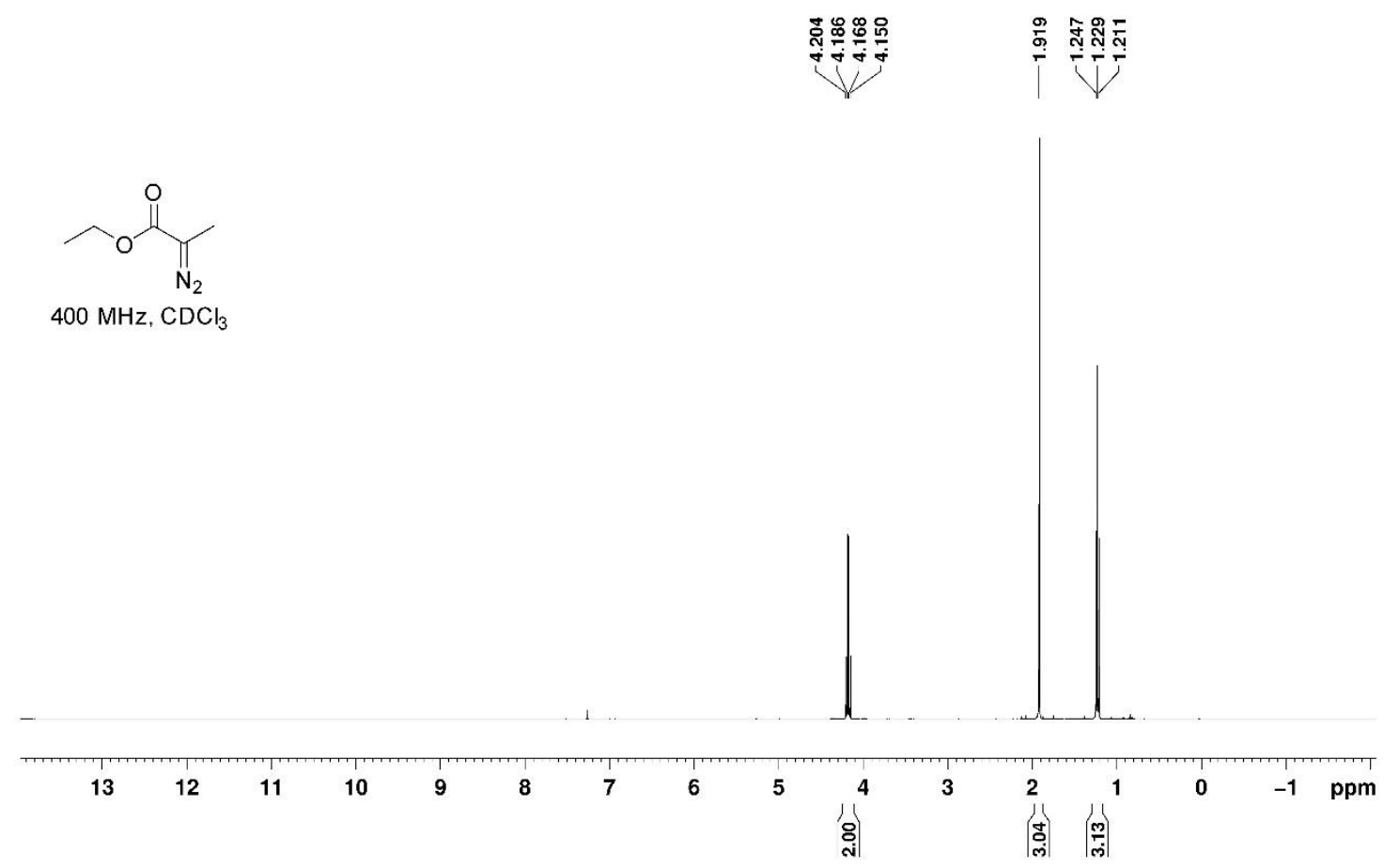




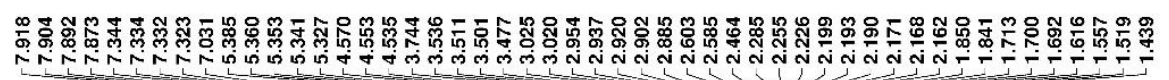

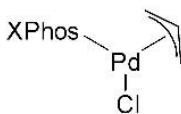

$400 \mathrm{MHz}, \mathrm{CDCl}_{3}$
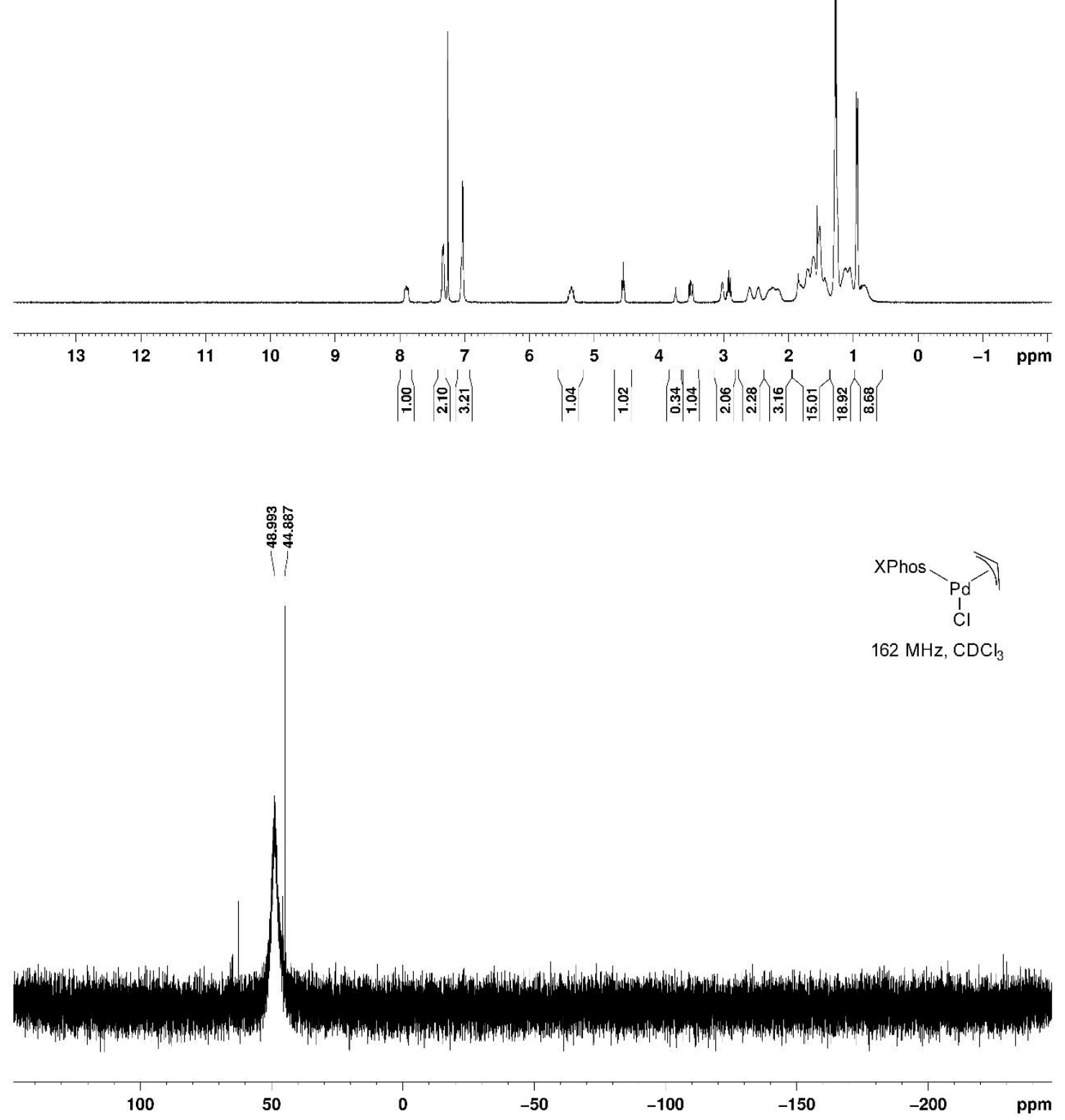


\section{Characterization data of cross-coupling products}

ethyl 2-(4-cyanophenyl)acrylate (1a)

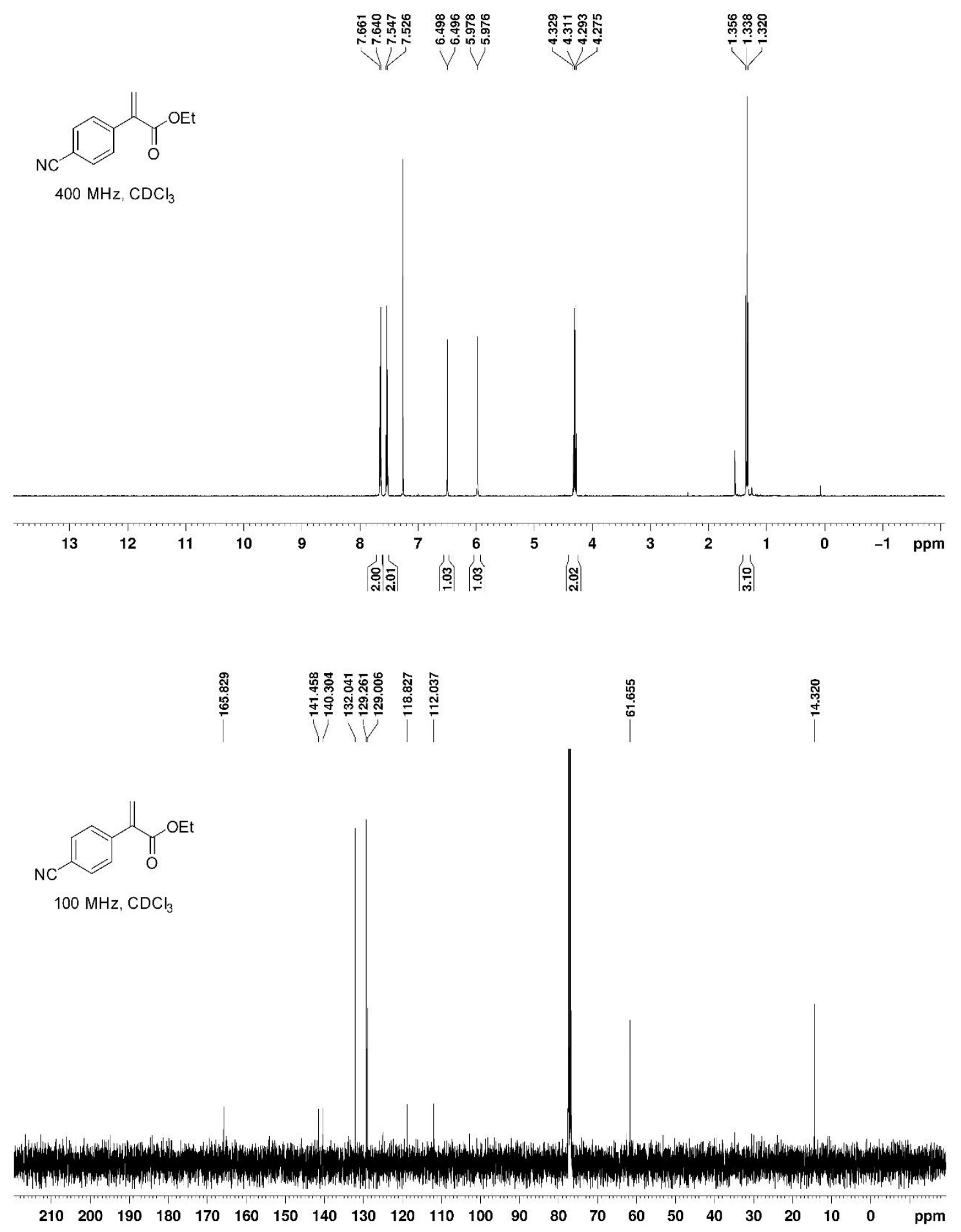


ethyl 2-(4-acetylphenyl)acrylate (1b)

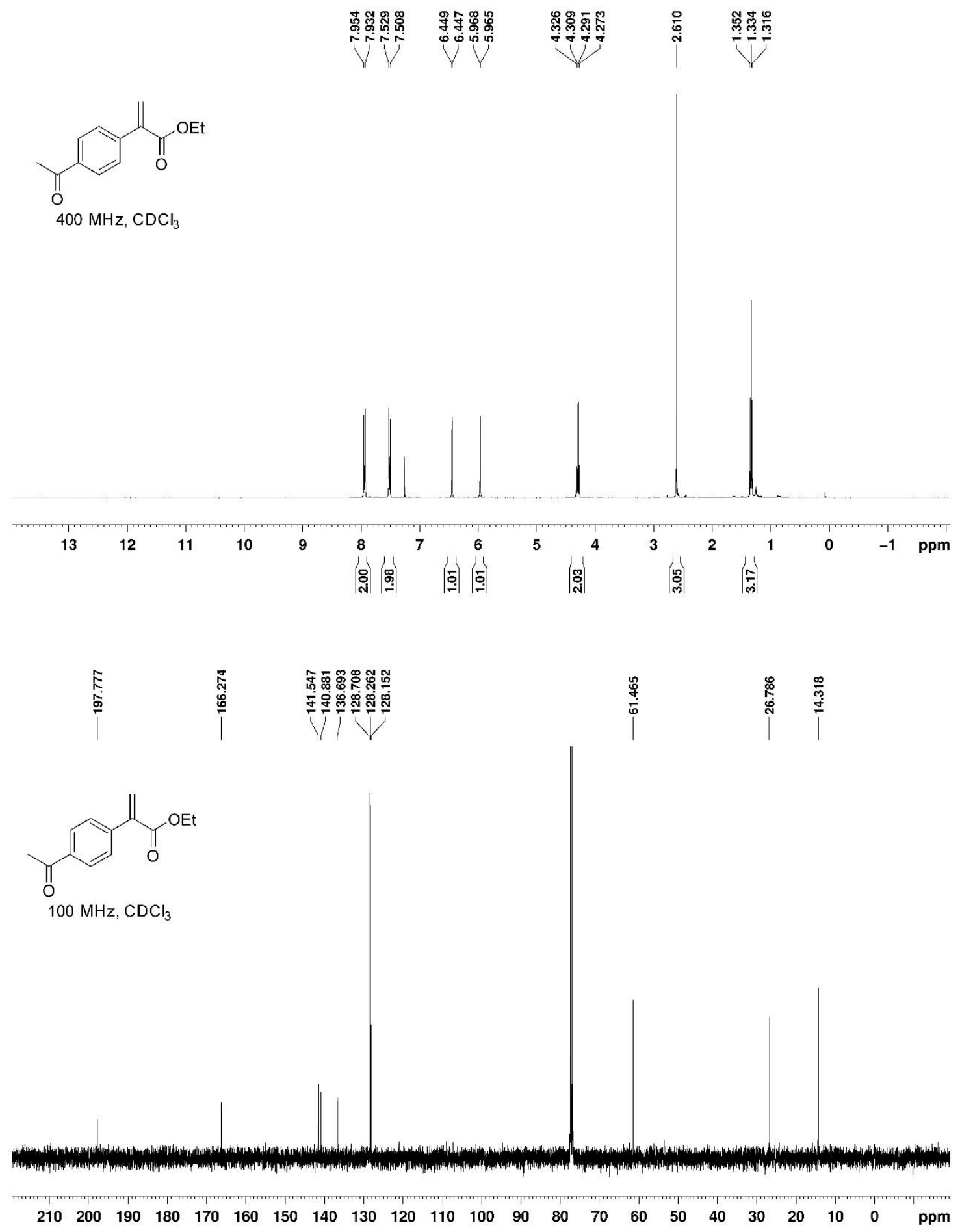


ethyl 2-(4-formylphenyl)acrylate (1c)
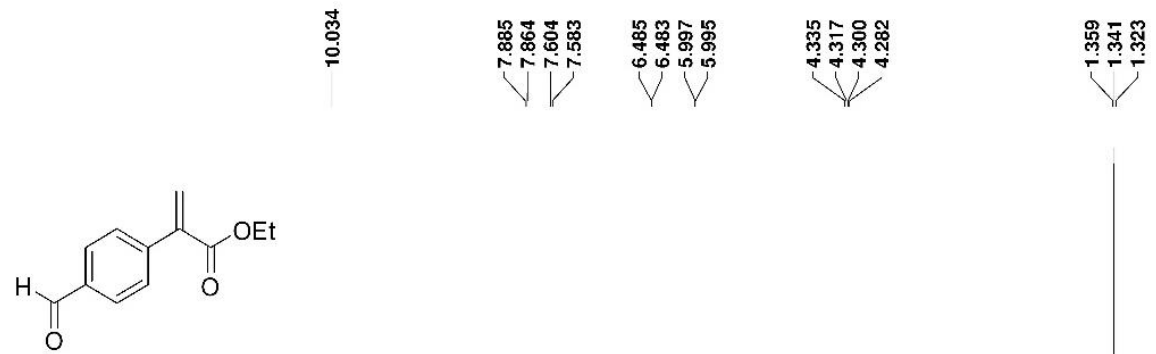

$400 \mathrm{MHz}, \mathrm{CDCl}_{3}$

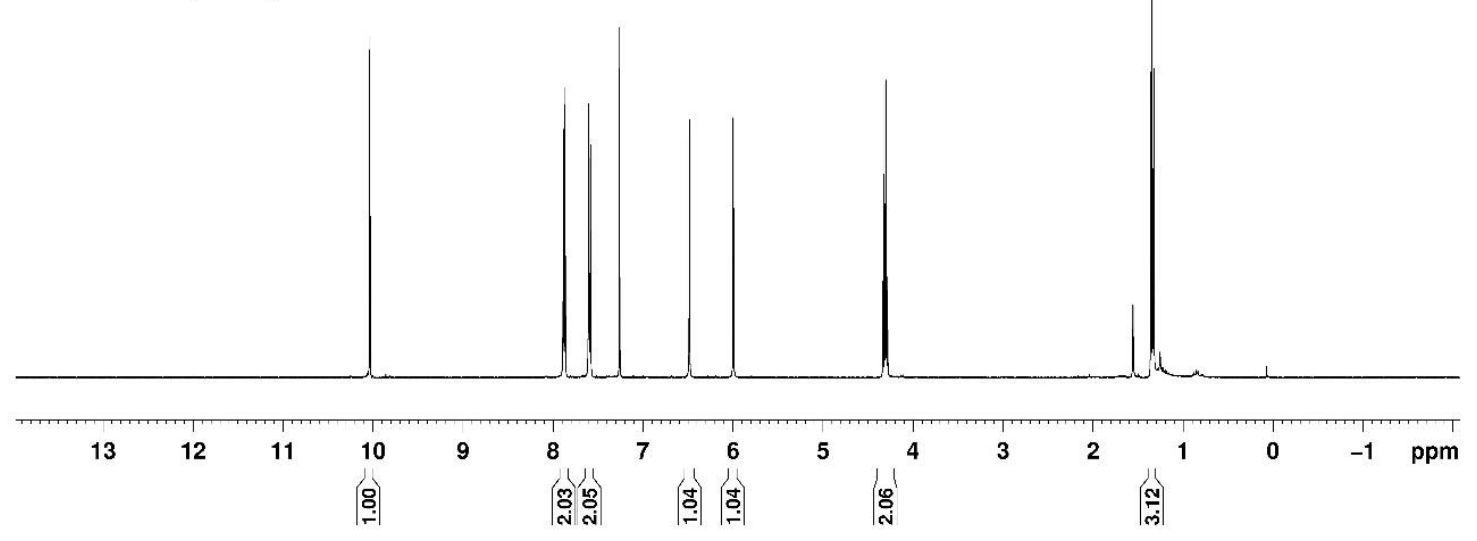

|

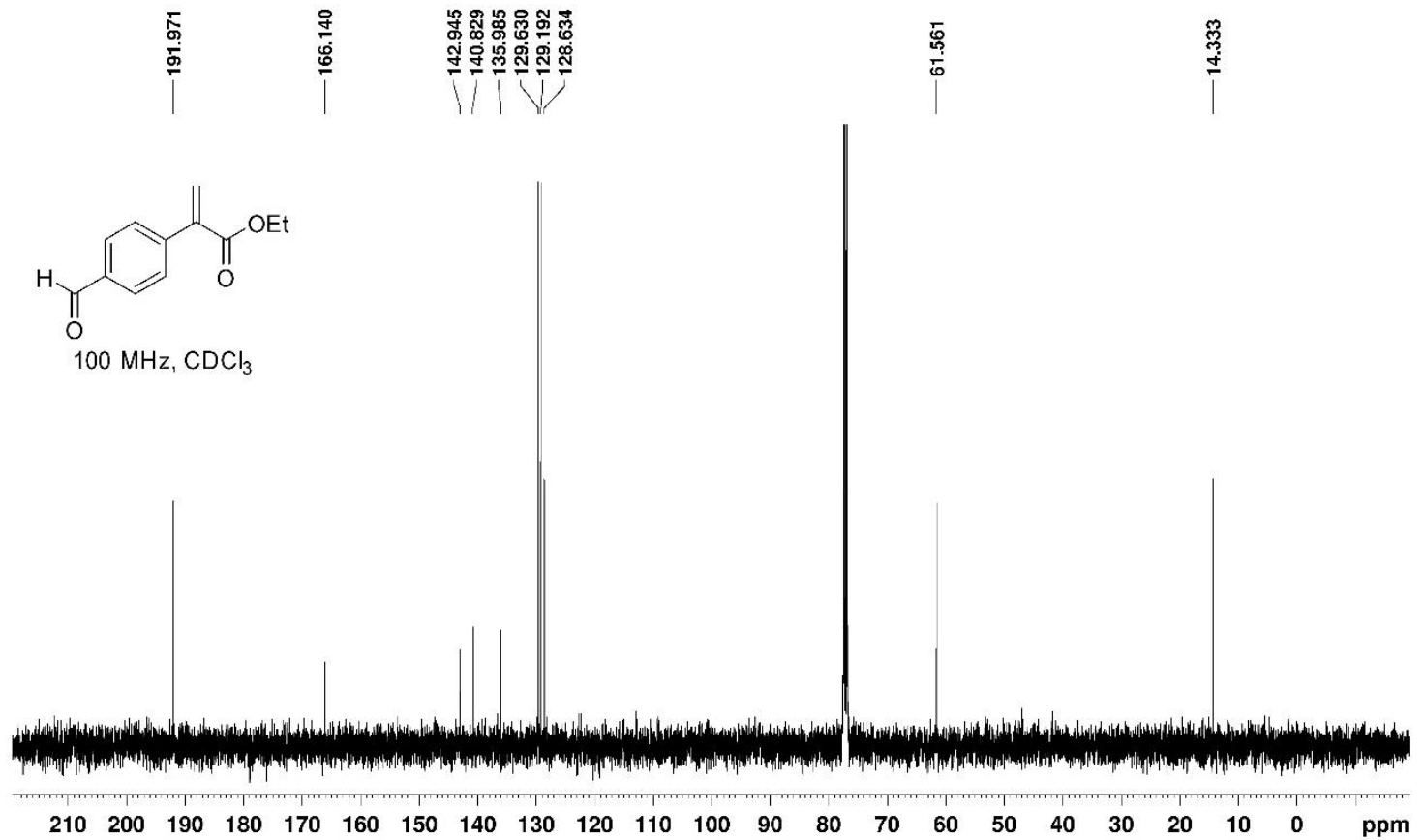

$100 \mathrm{MHz} \mathrm{CDCl}_{3}$ 
ethyl 2-(4-chalcon-4-yl)acrylate (1d)

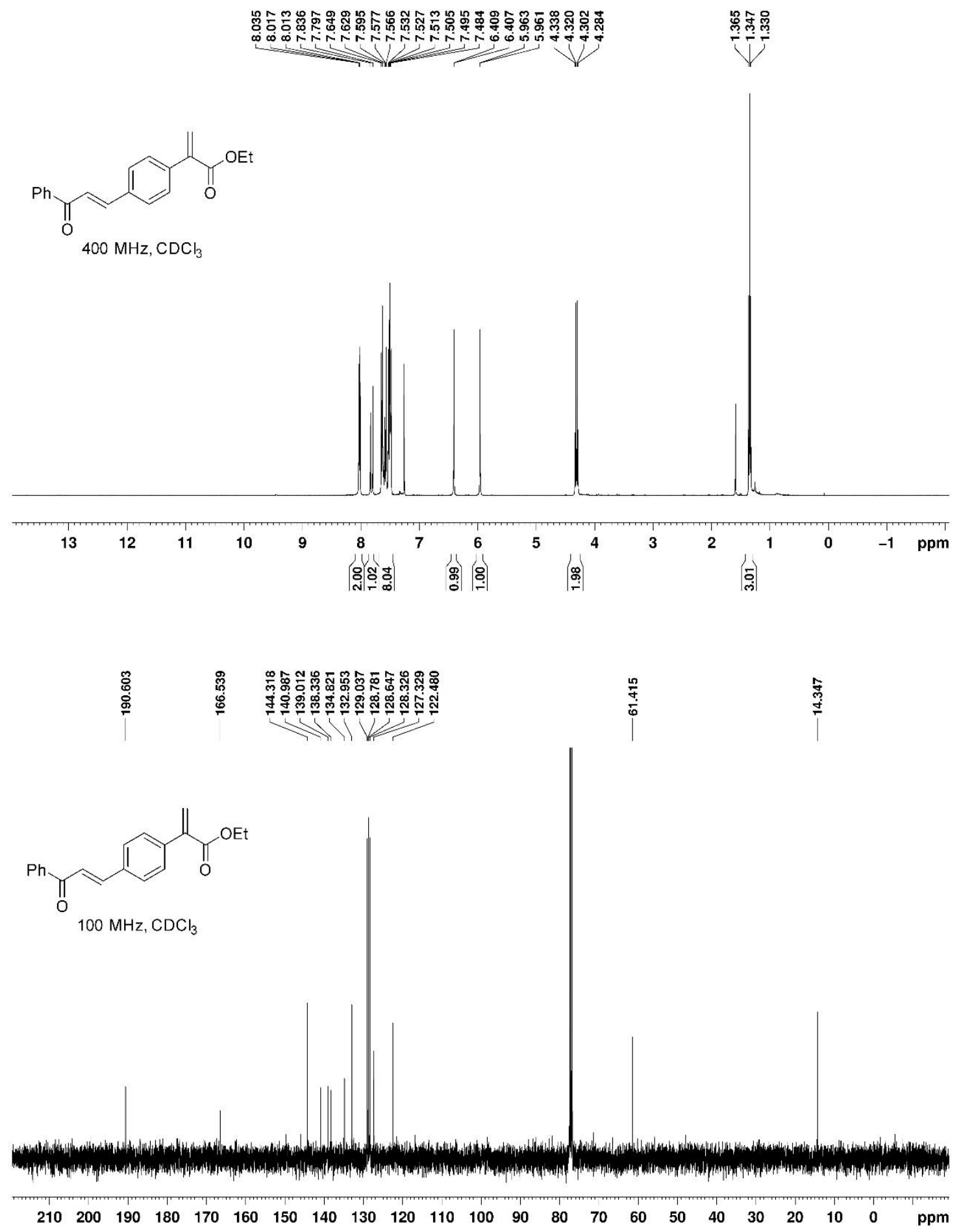


ethyl 2-phenylacrylate (1e)

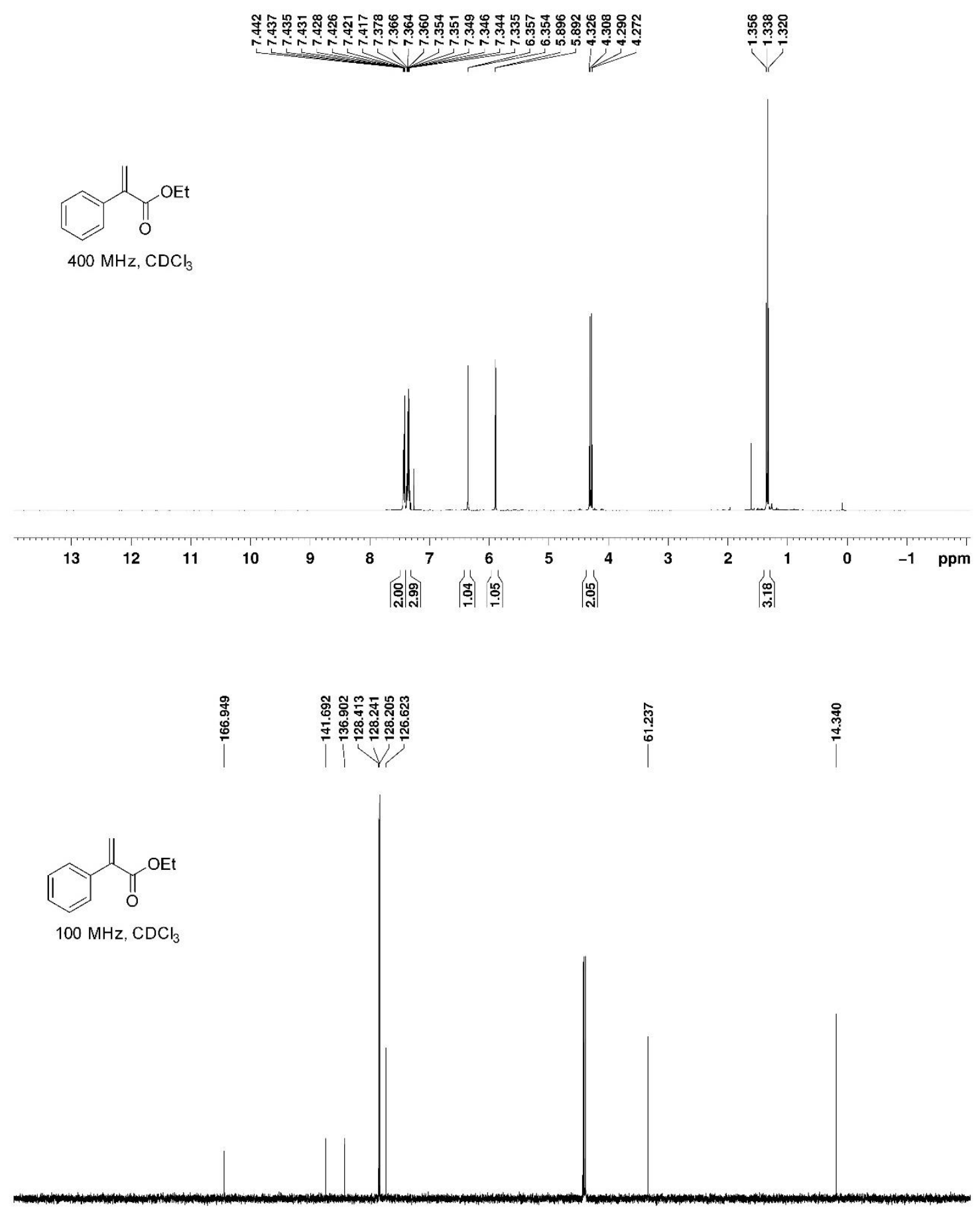

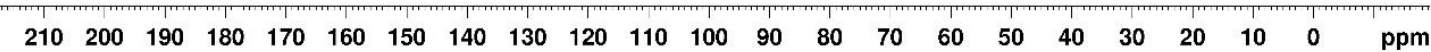


ethyl 2-(4-styenyl)acrylate (1f)

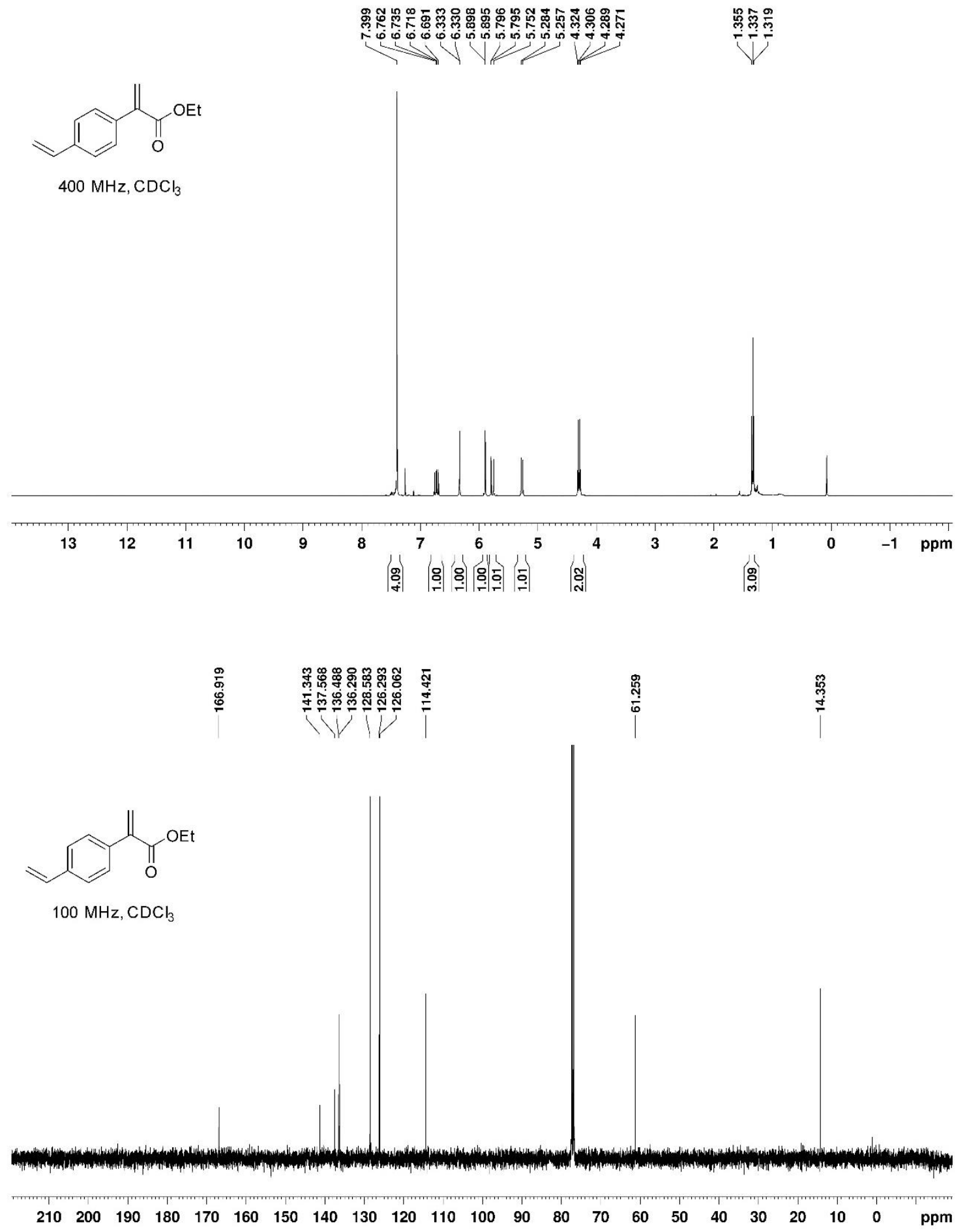


ethyl 2-(4-methylthiophenyl)acrylate (1g)

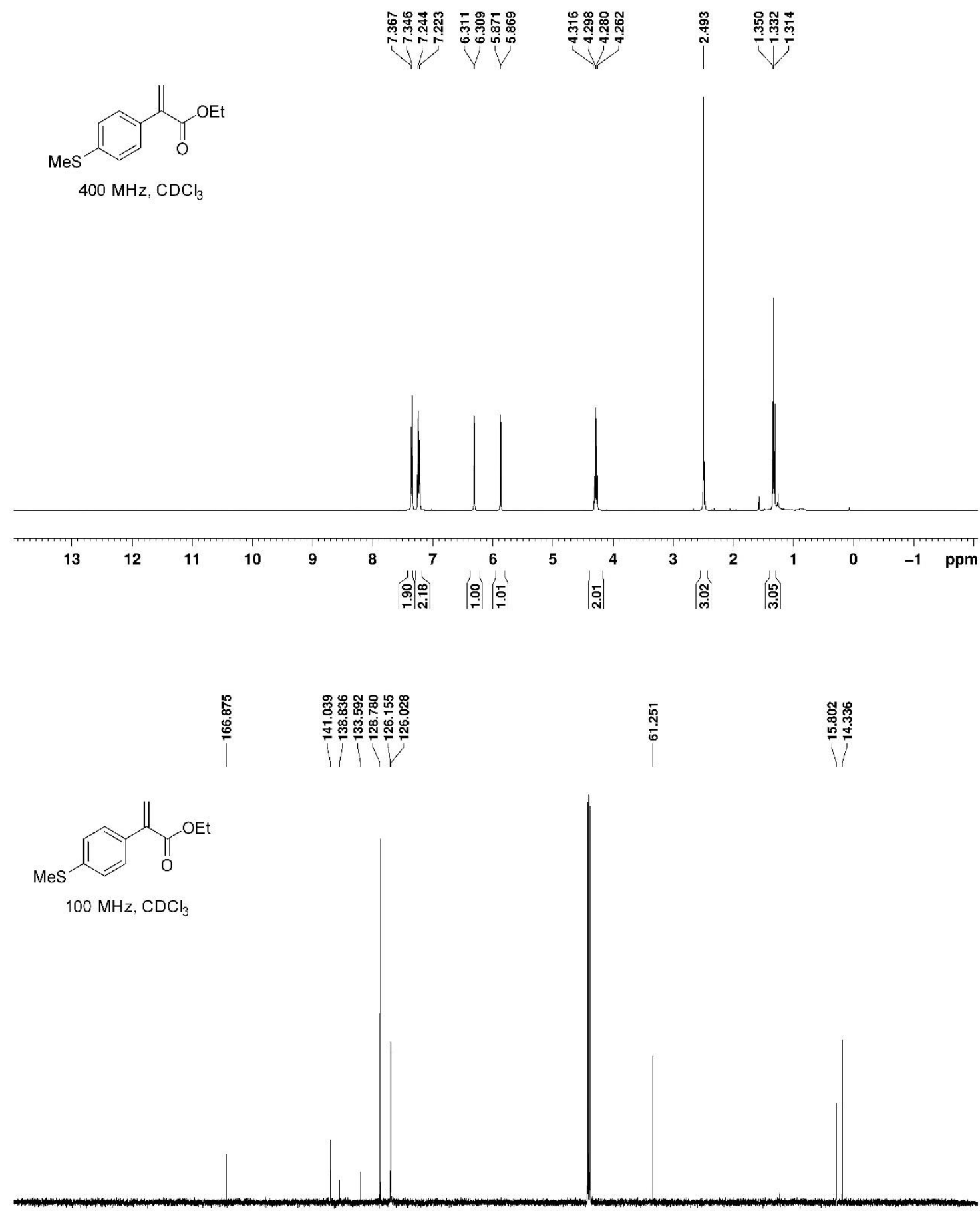

$\begin{array}{llllllllllllllllllllllll}210 & 200 & 190 & 180 & 170 & 160 & 150 & 140 & 130 & 120 & 110 & 100 & 90 & 80 & 70 & 60 & 50 & 40 & 30 & 20 & 10 & 0 & \mathrm{ppm}\end{array}$ 
ethyl 2-(4-methoxyphenyl)acrylate (1h)

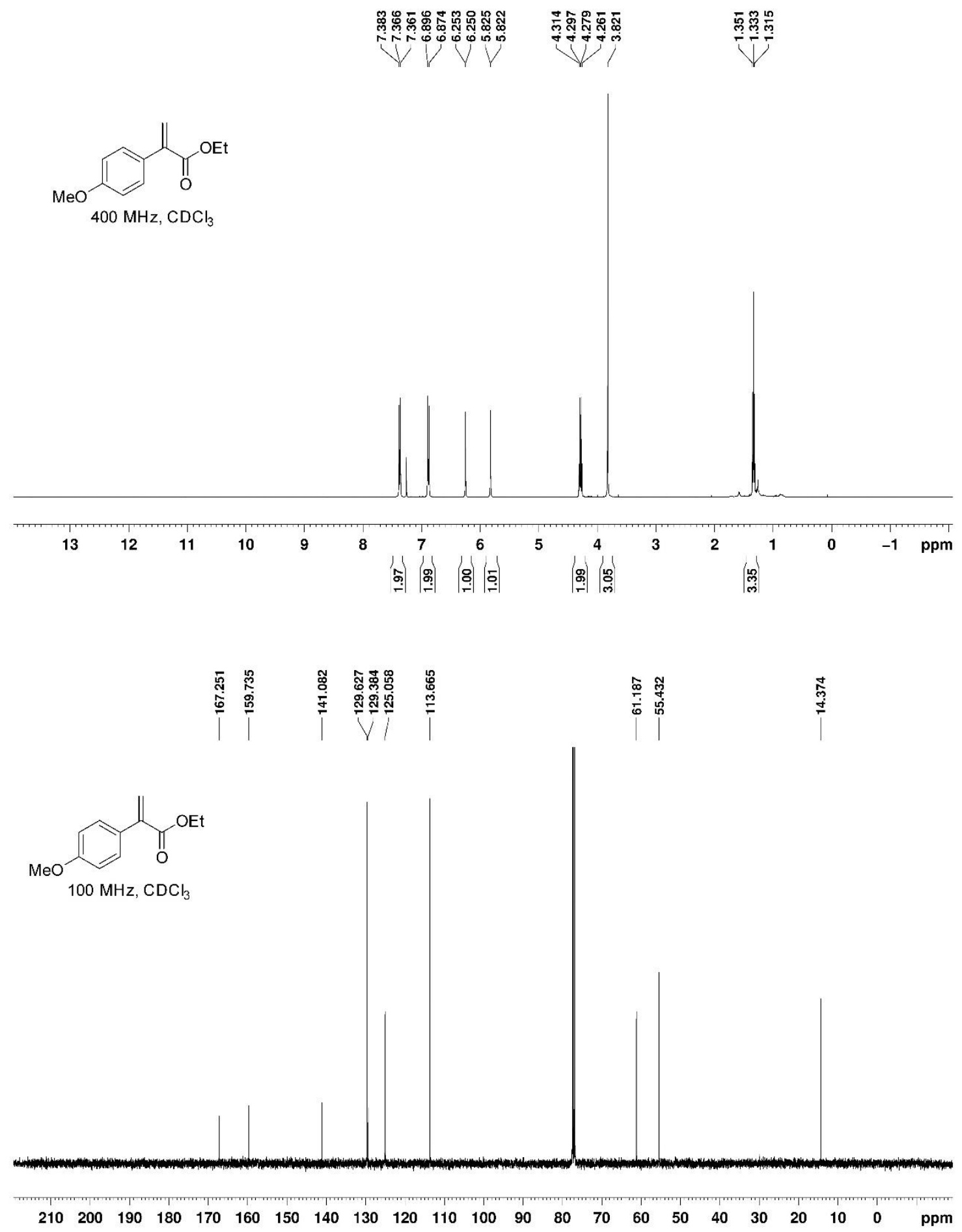


ethyl 2-(2,6-dimethylphenyl)acrylate (1i)

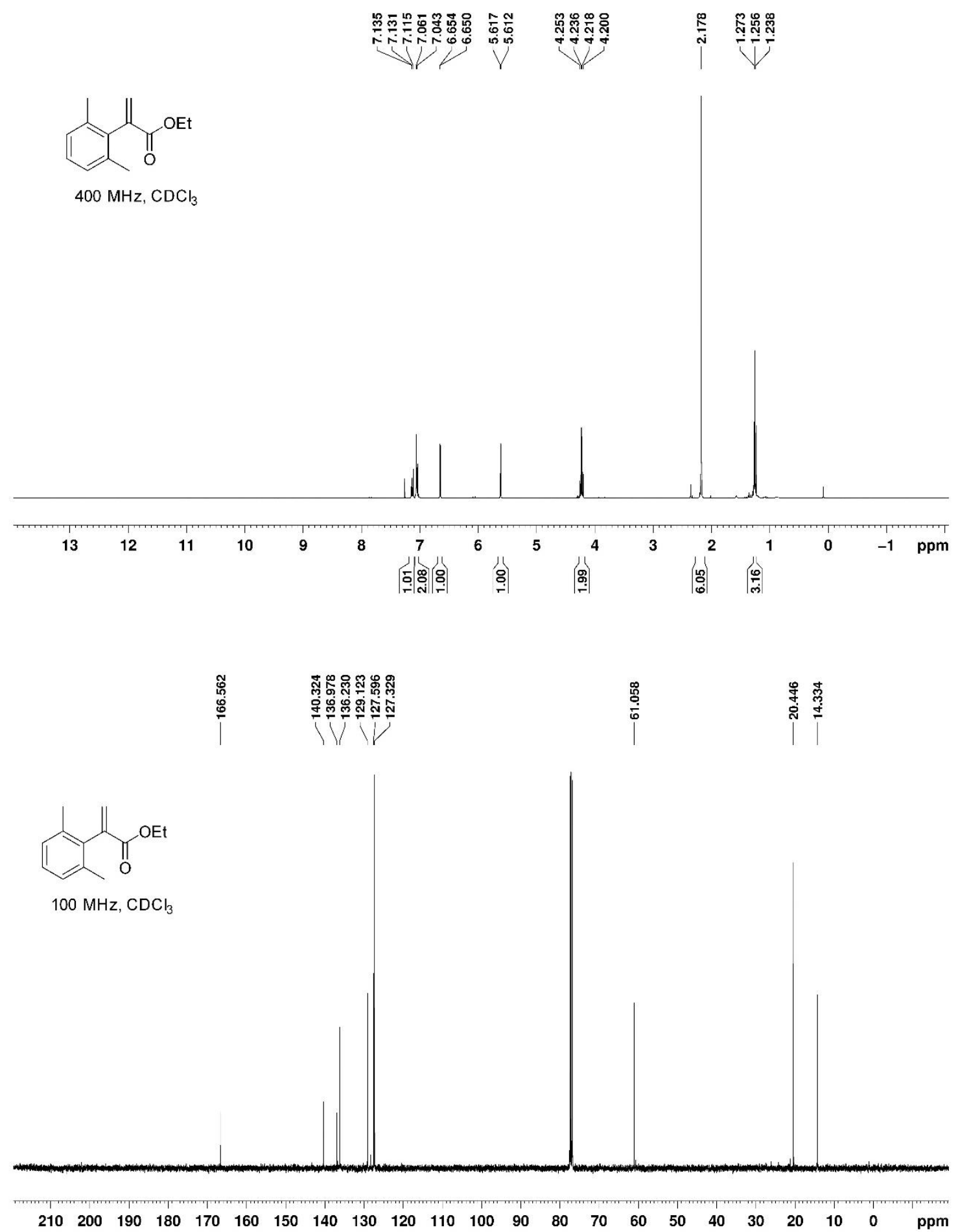


ethyl 2-(indol-4-yl)acrylate (1j)
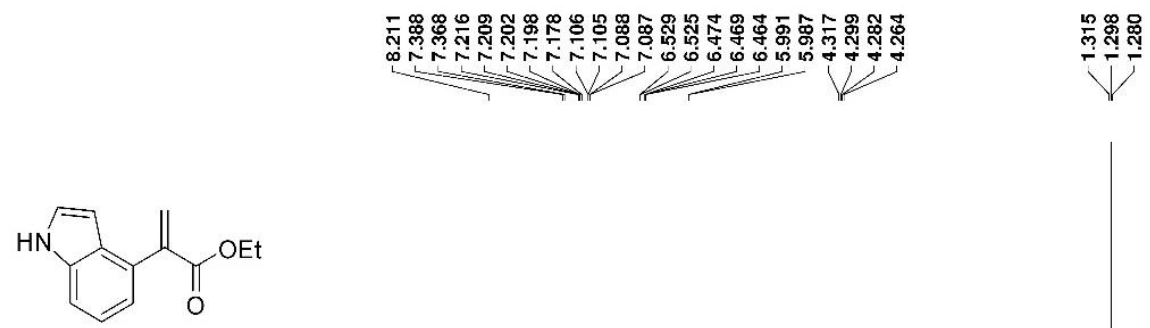

$400 \mathrm{MHz}, \mathrm{CDC}_{3}$
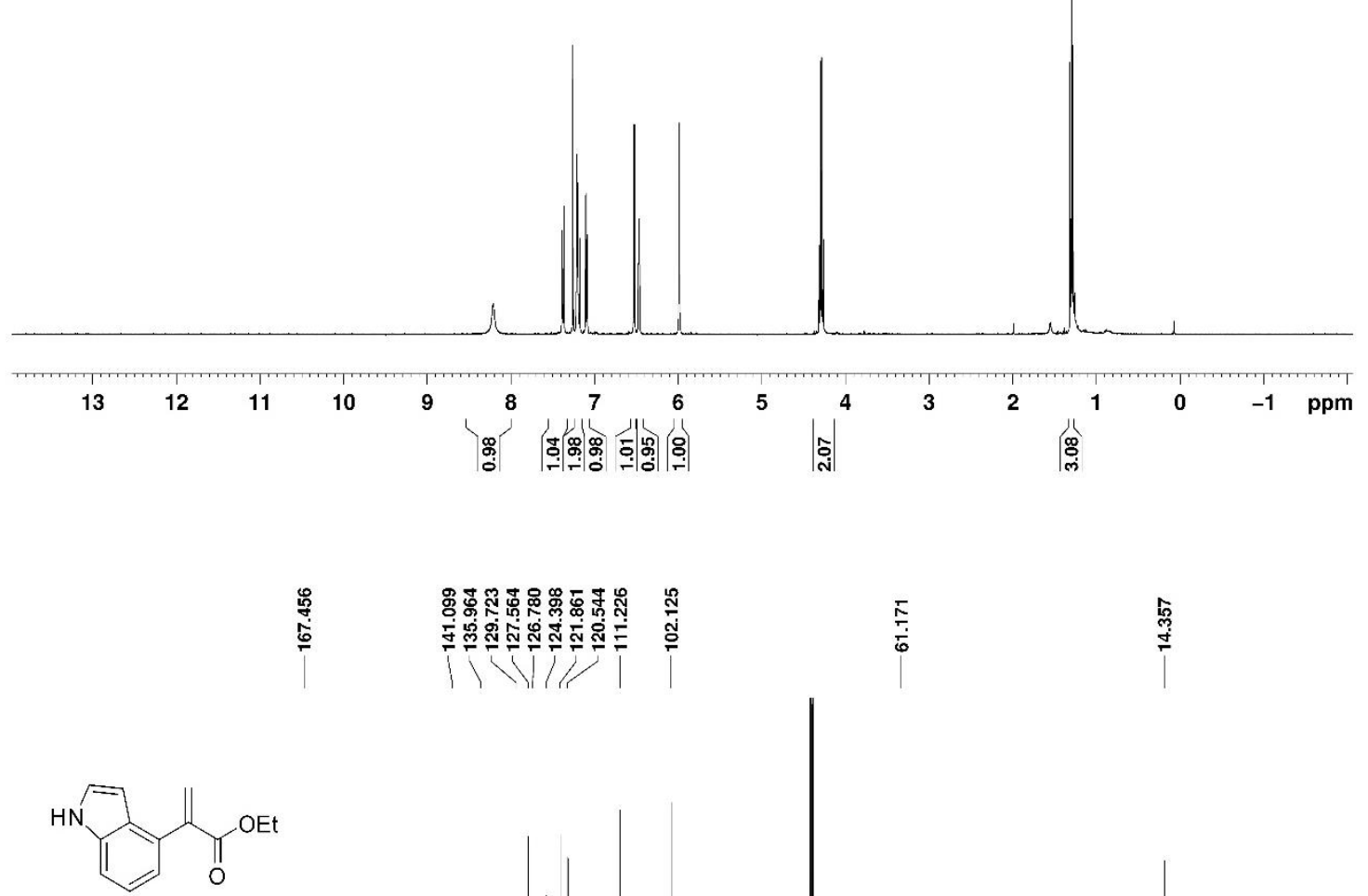

$100 \mathrm{MHz}, \mathrm{CDCl}_{3}$

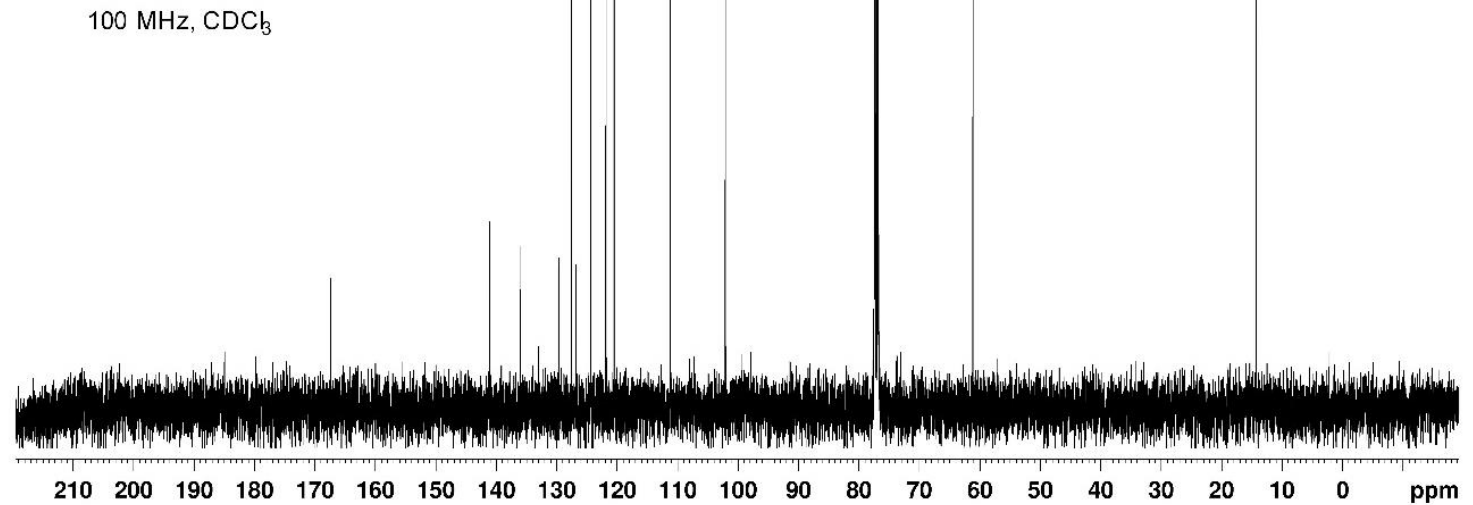


ethyl 2-(1,3-benzodioxol-5-yl)acrylate (1k)

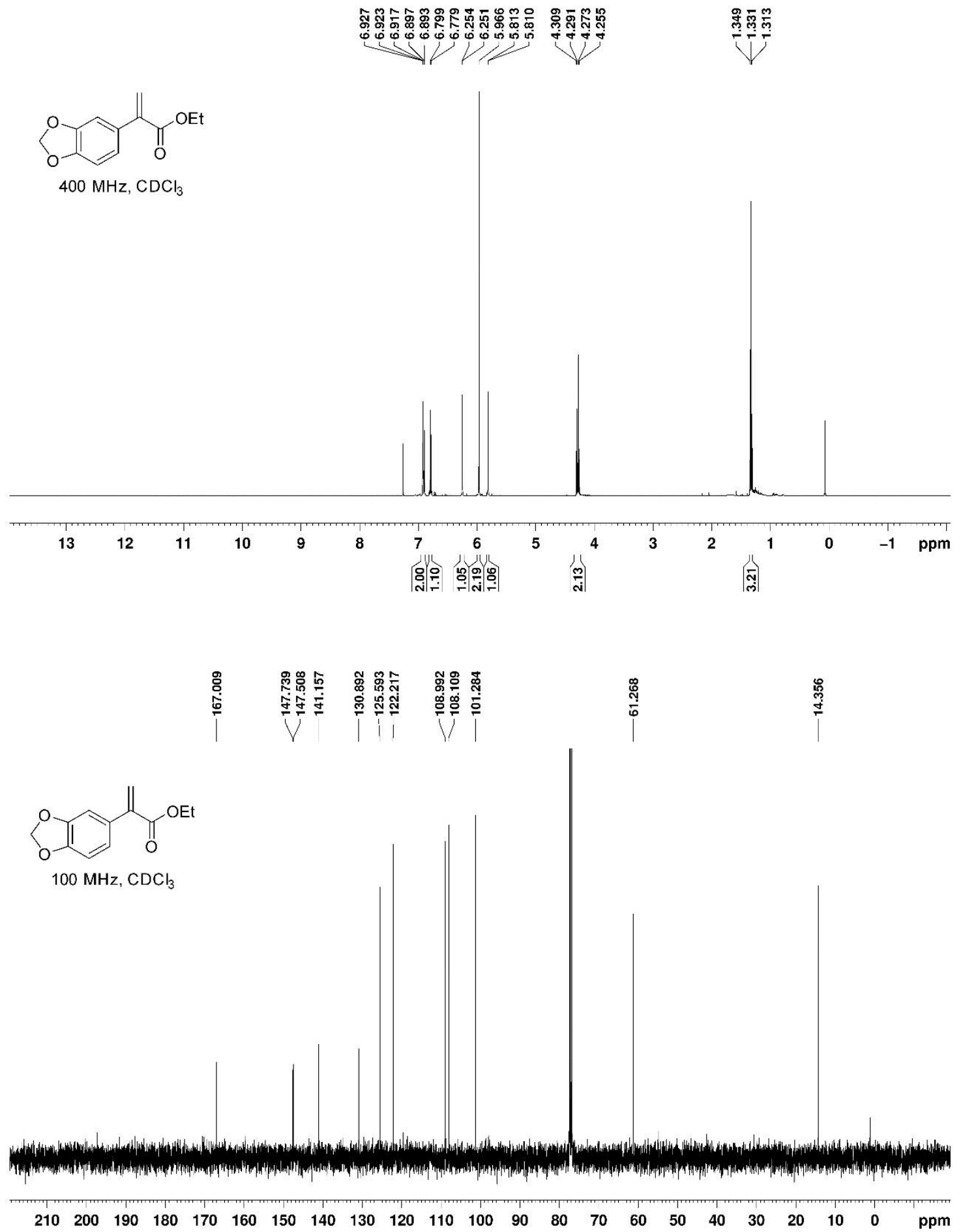


1,1-diphenylethylene (2a)

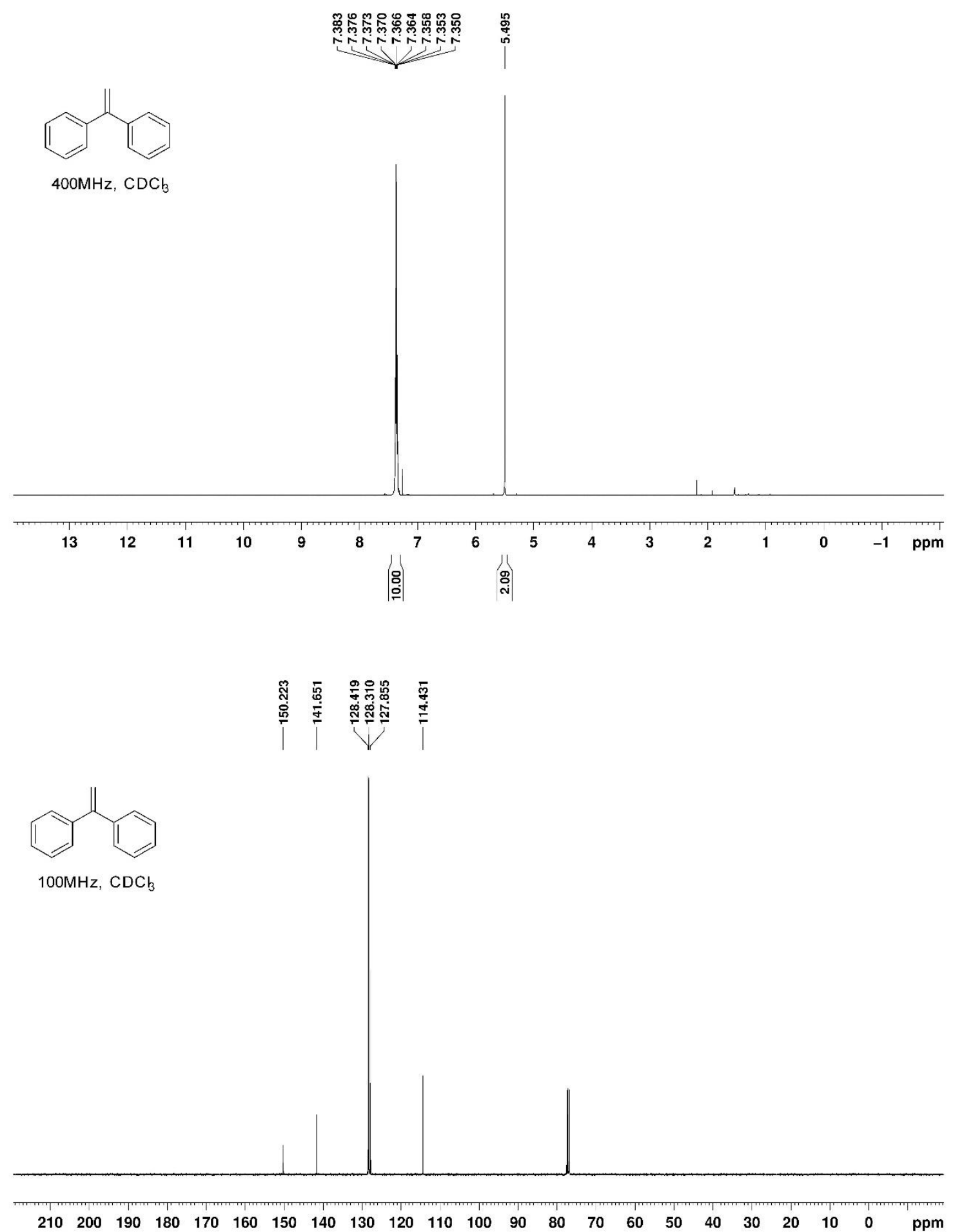


1-(4-trifluoromethylphenyl)-1-phenylethylene (2b)
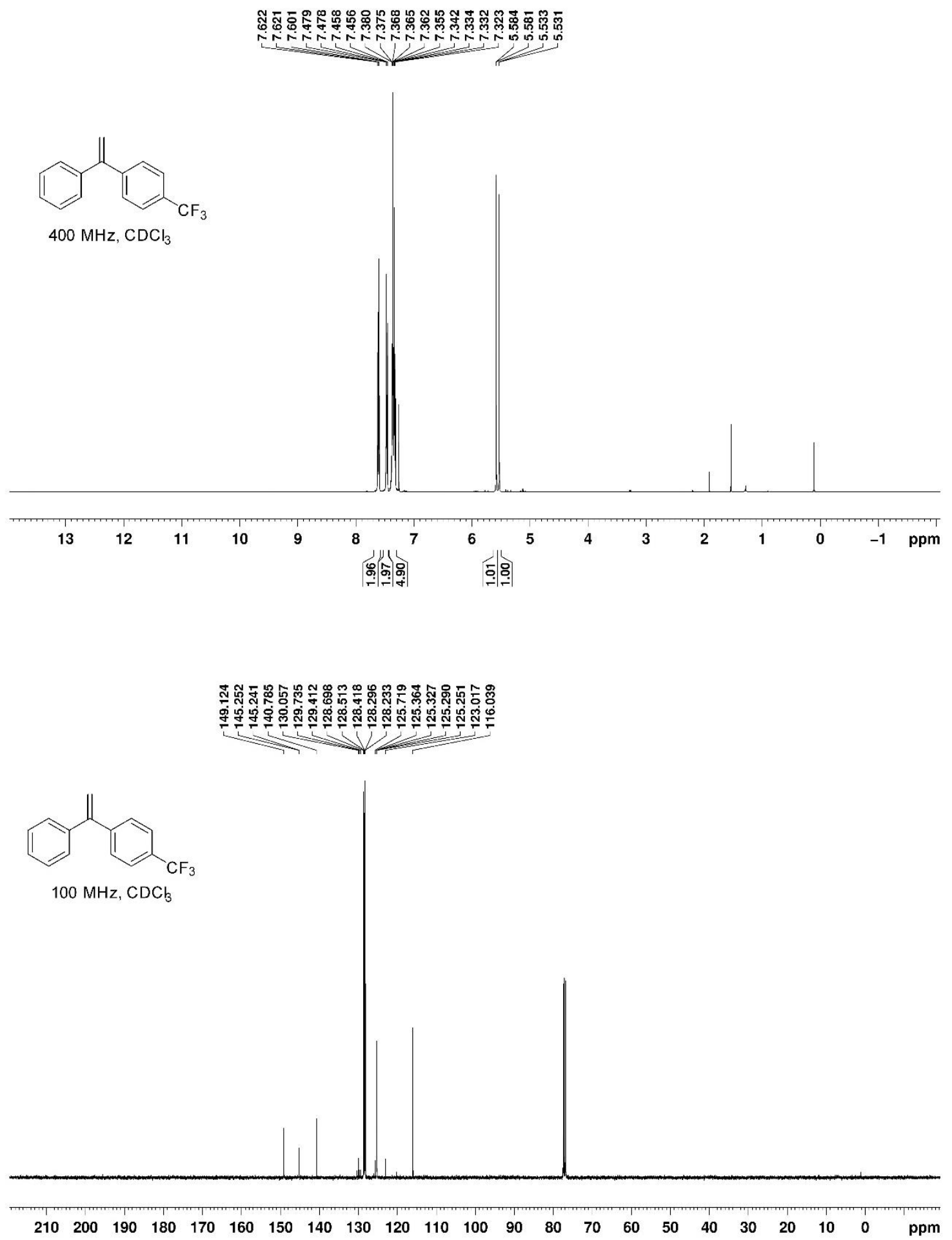


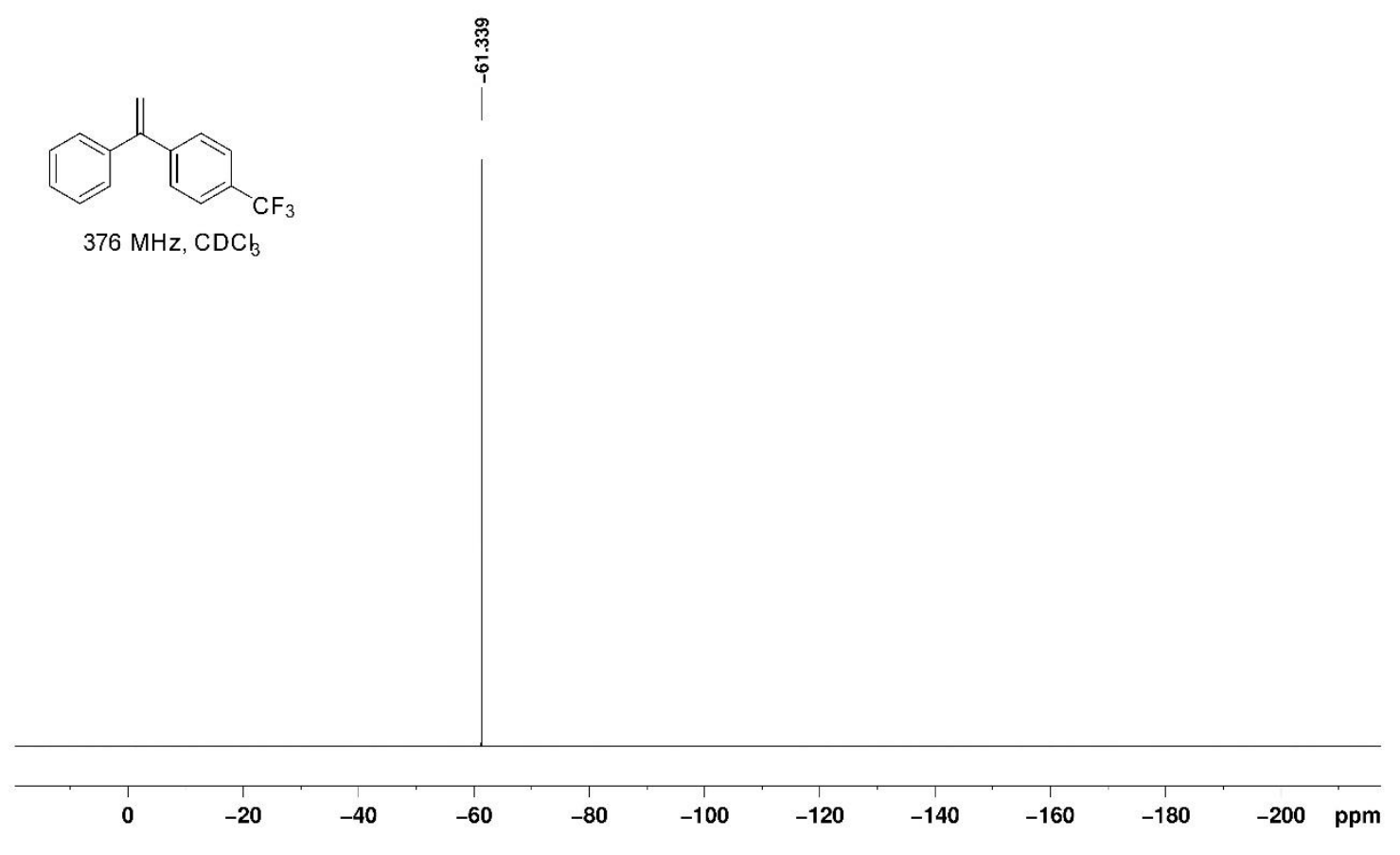


1-(4-nitrophenyl)-1-phenylethylene (2c)
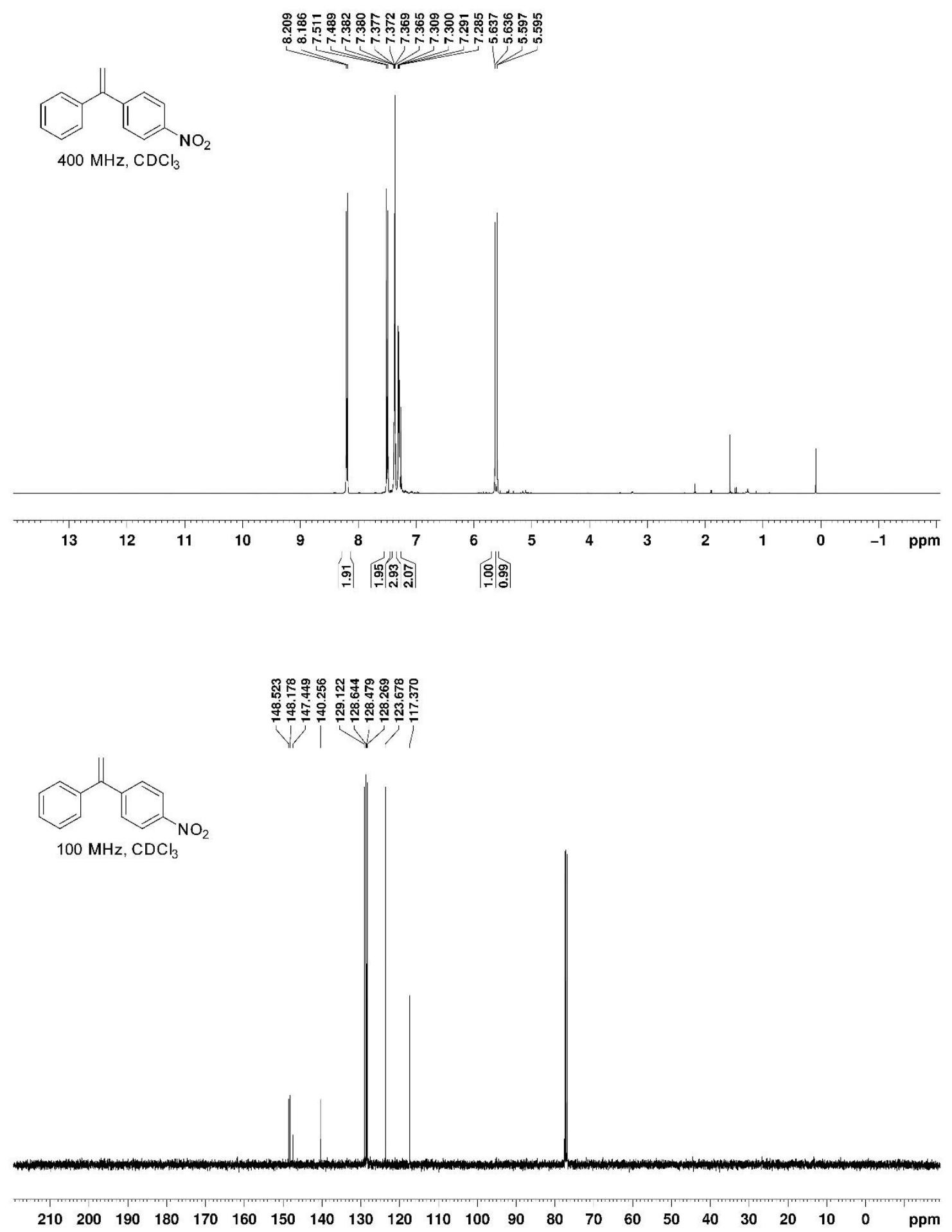
1-(4-benzophenon-4-yl)-1-phenylethylene (2d)
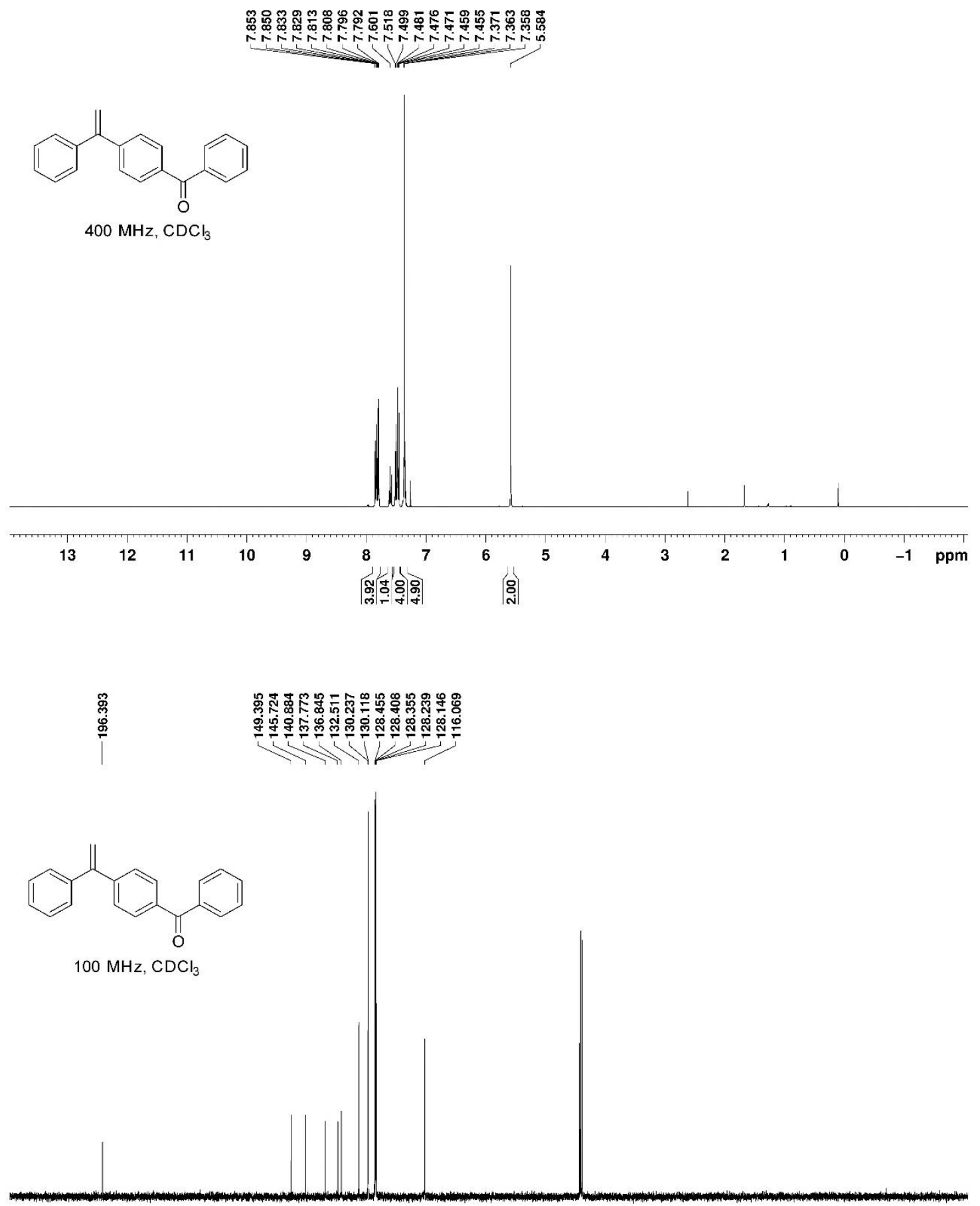

$\begin{array}{lllllllllllllllllllllll}210 & 200 & 190 & 180 & 170 & 160 & 150 & 140 & 130 & 120 & 110 & 100 & 90 & 80 & 70 & 60 & 50 & 40 & 30 & 20 & 10 & 0 & \mathrm{ppm}\end{array}$ 
1-phenyl-1-(tol-4-yl)ethylene (2e)
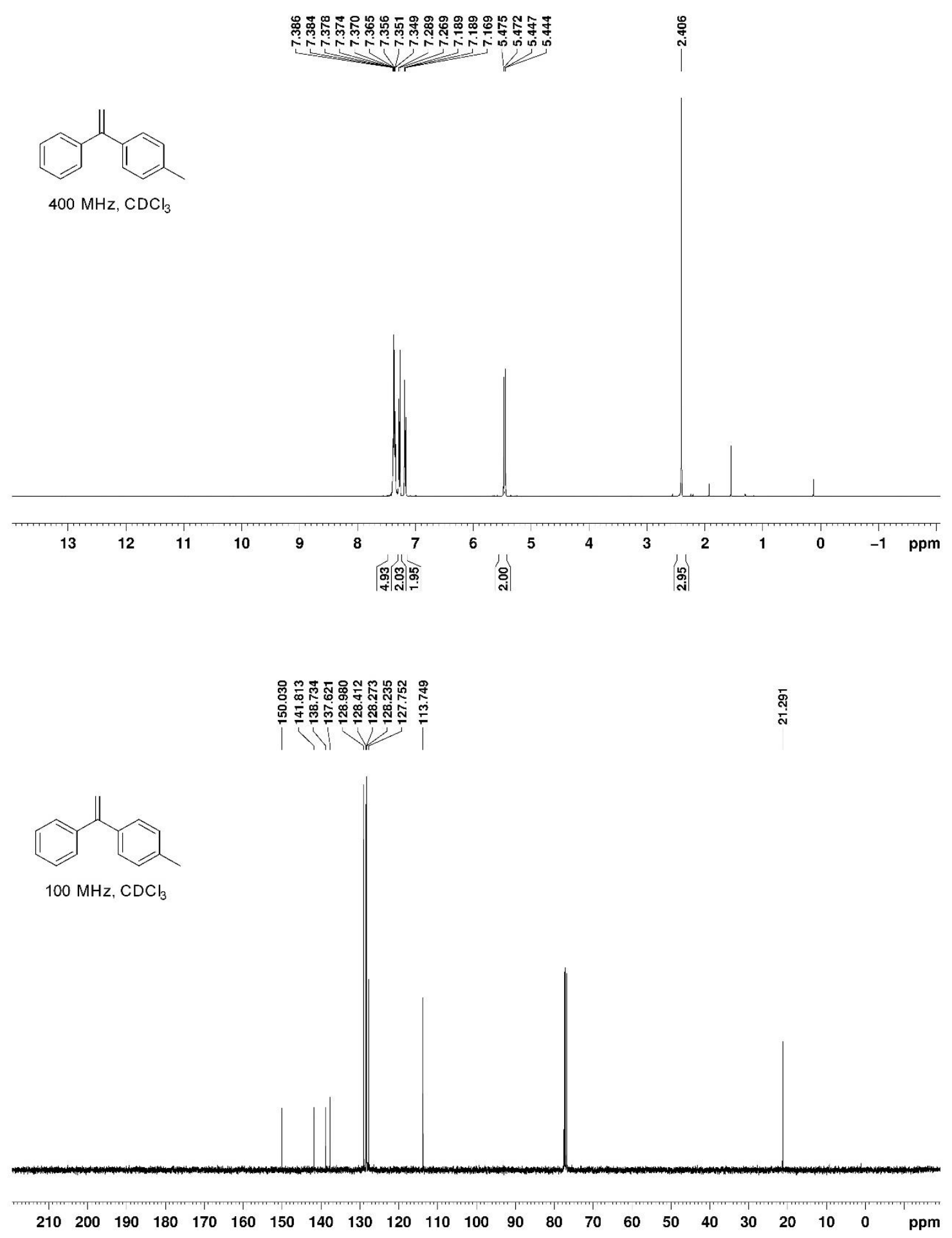
1-(4-methoxy-3-methylphenyl)-1-phenylethylene (2f)

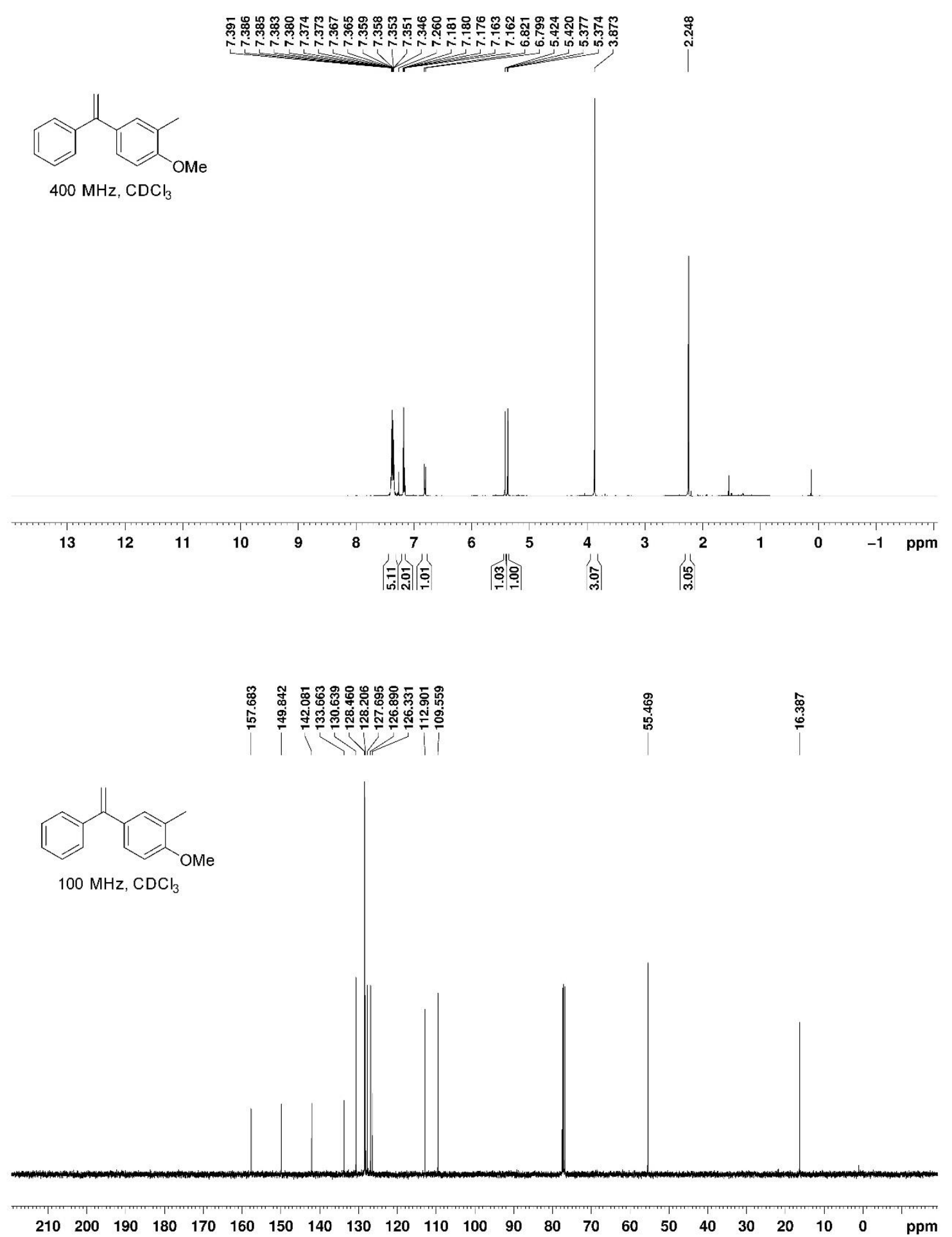


1-(2,5-dimethylphenyl)-1-phenylethylene (2g)

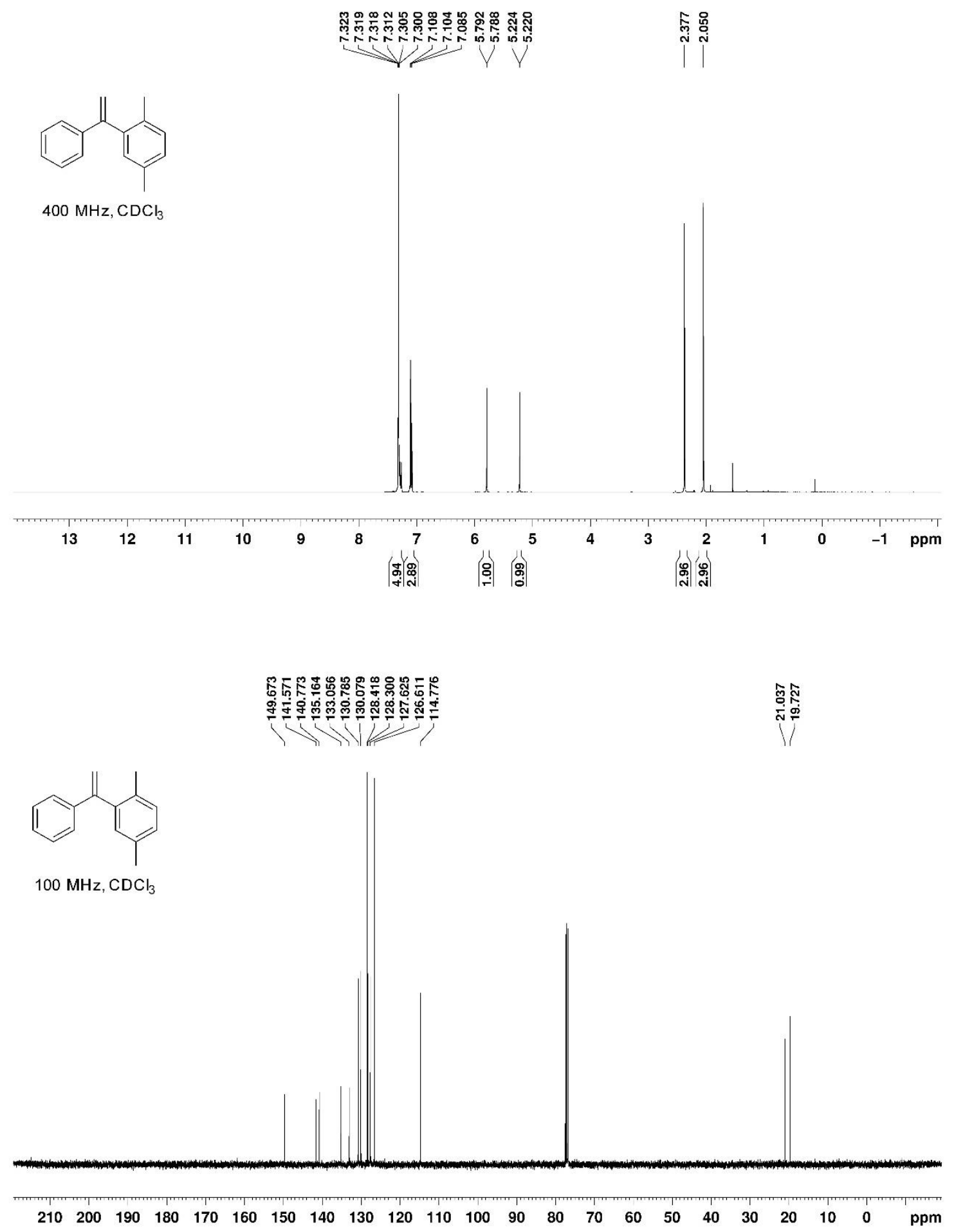


1-(2-cyanomethyl-4,5-dimethoxyphenyl)-1-phenylethylene (2h)

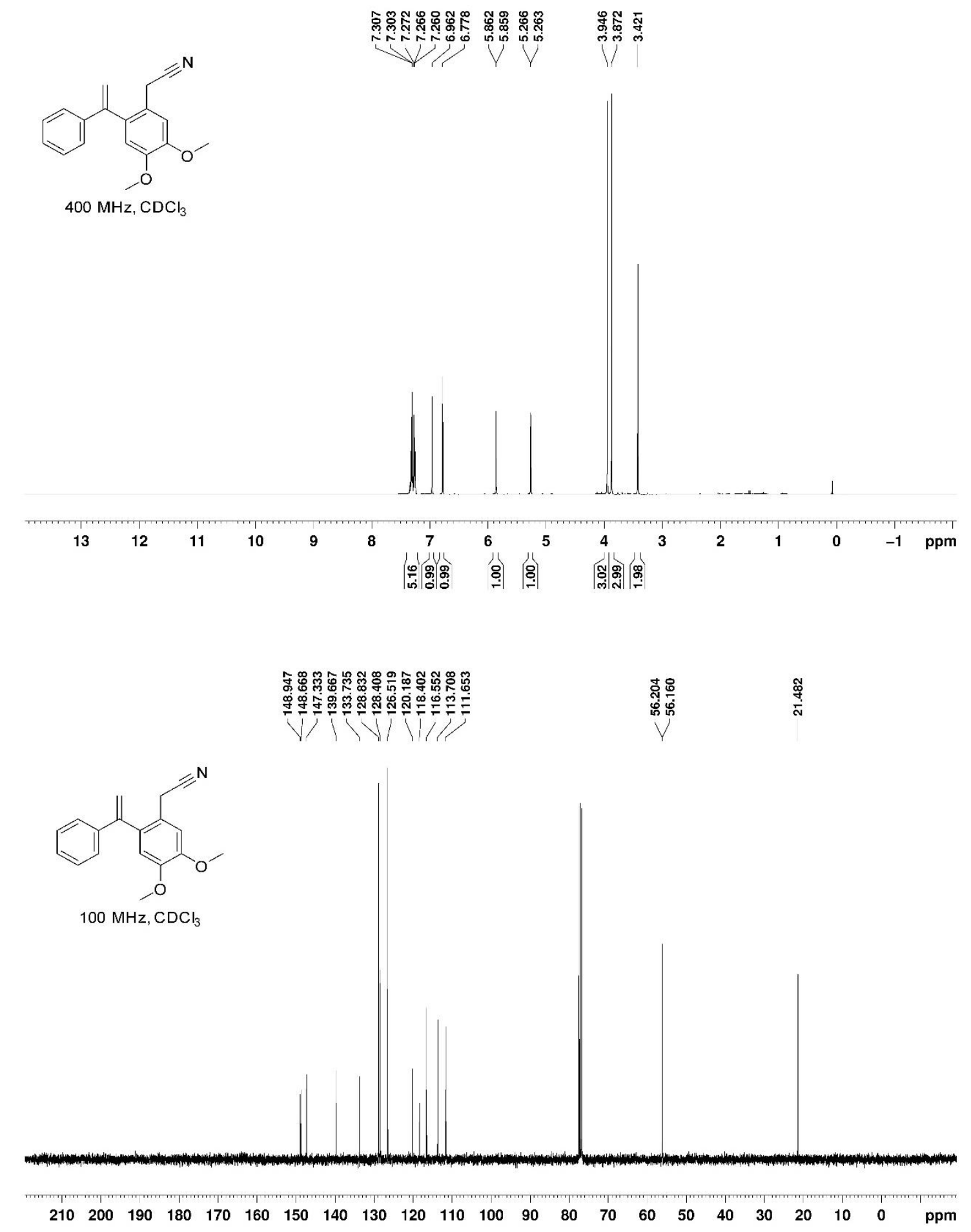


1-(4-hydroxymethylphenyl)-1-phenylethylene (2i)
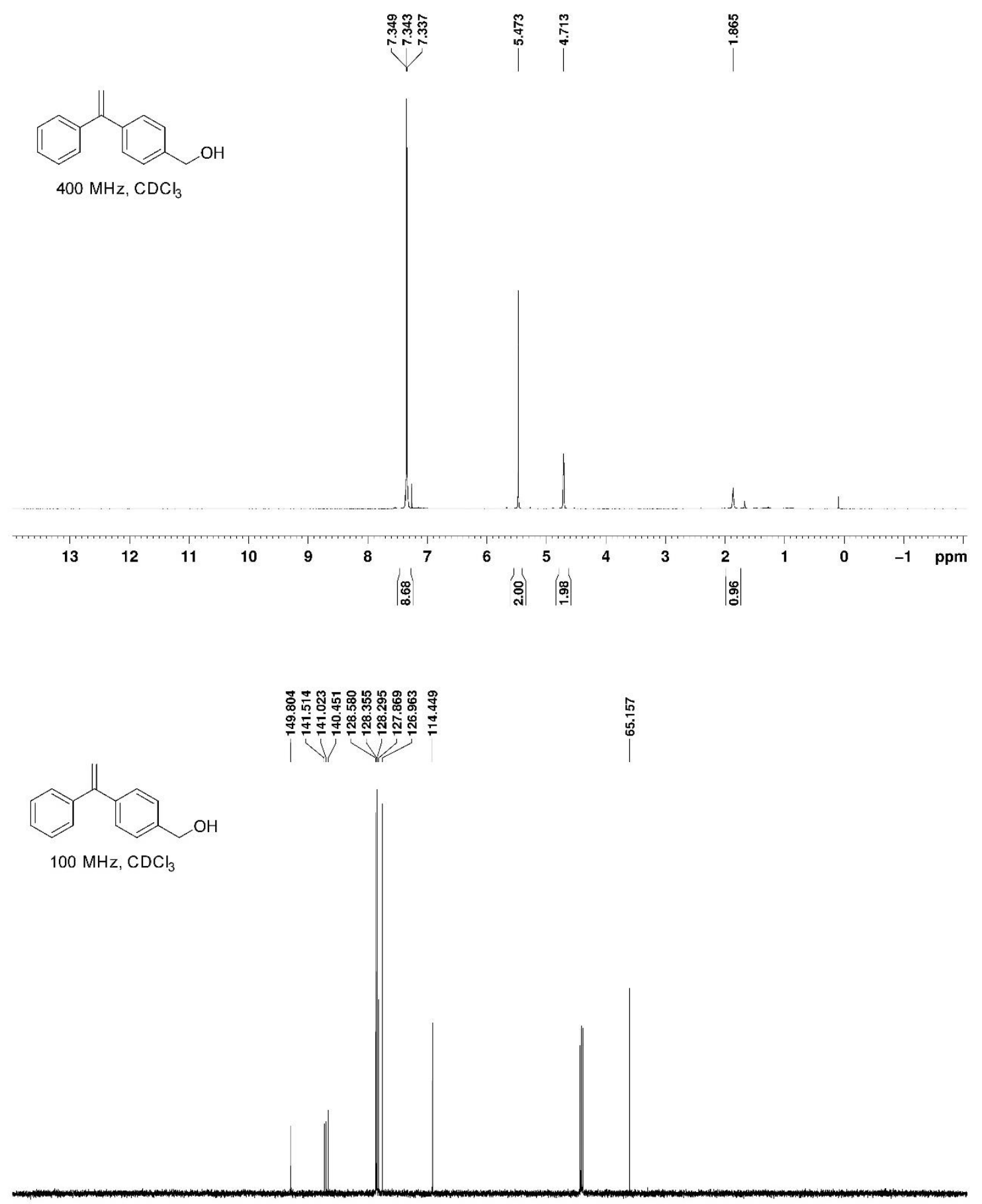

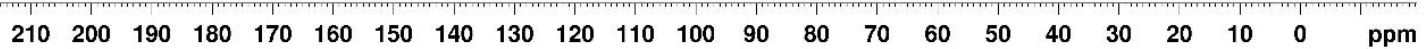


1-(4-aminophenyl)-1-phenylethylene (2j)
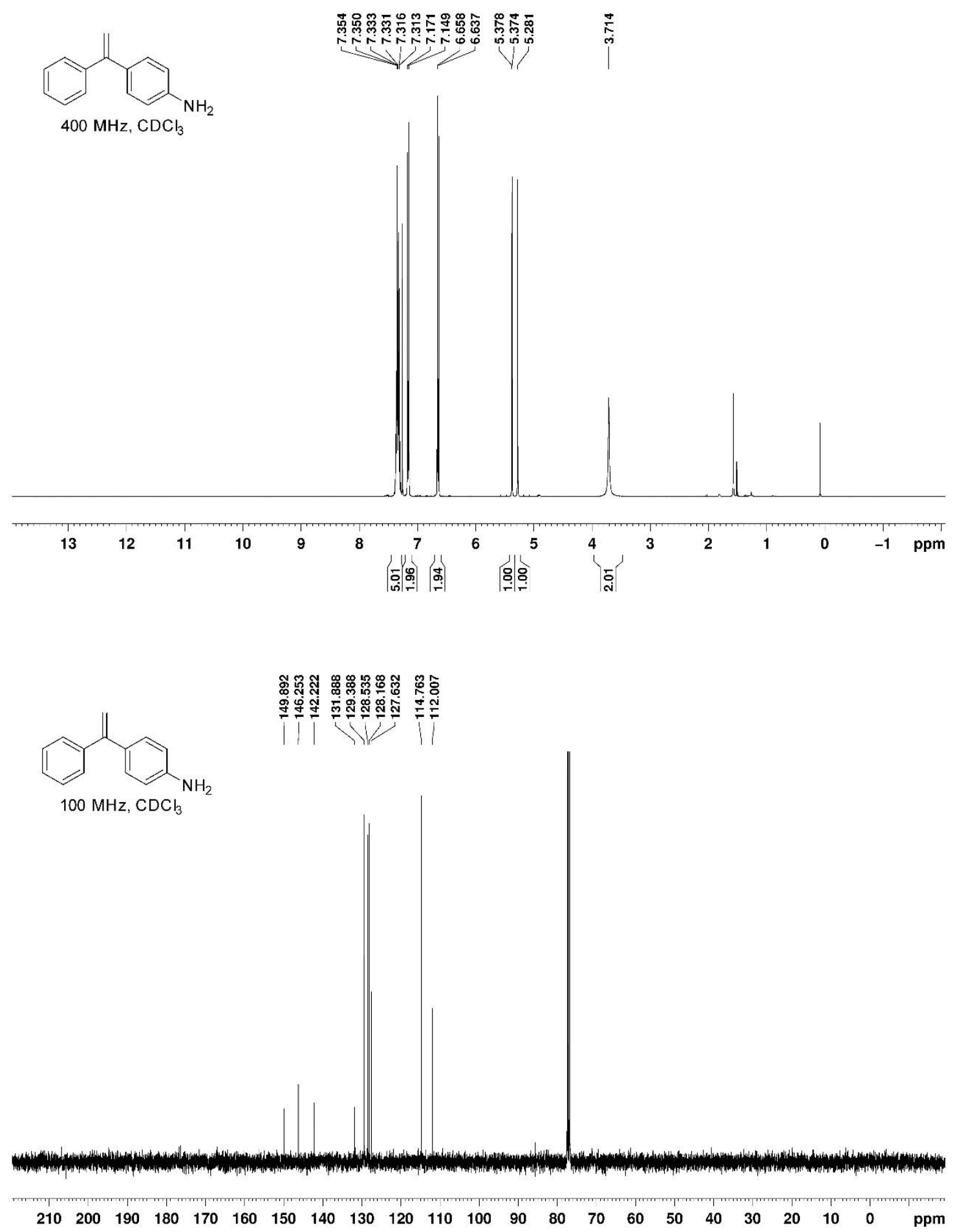
1-(4-chlorophenyl)-1-phenylethylene (2k)
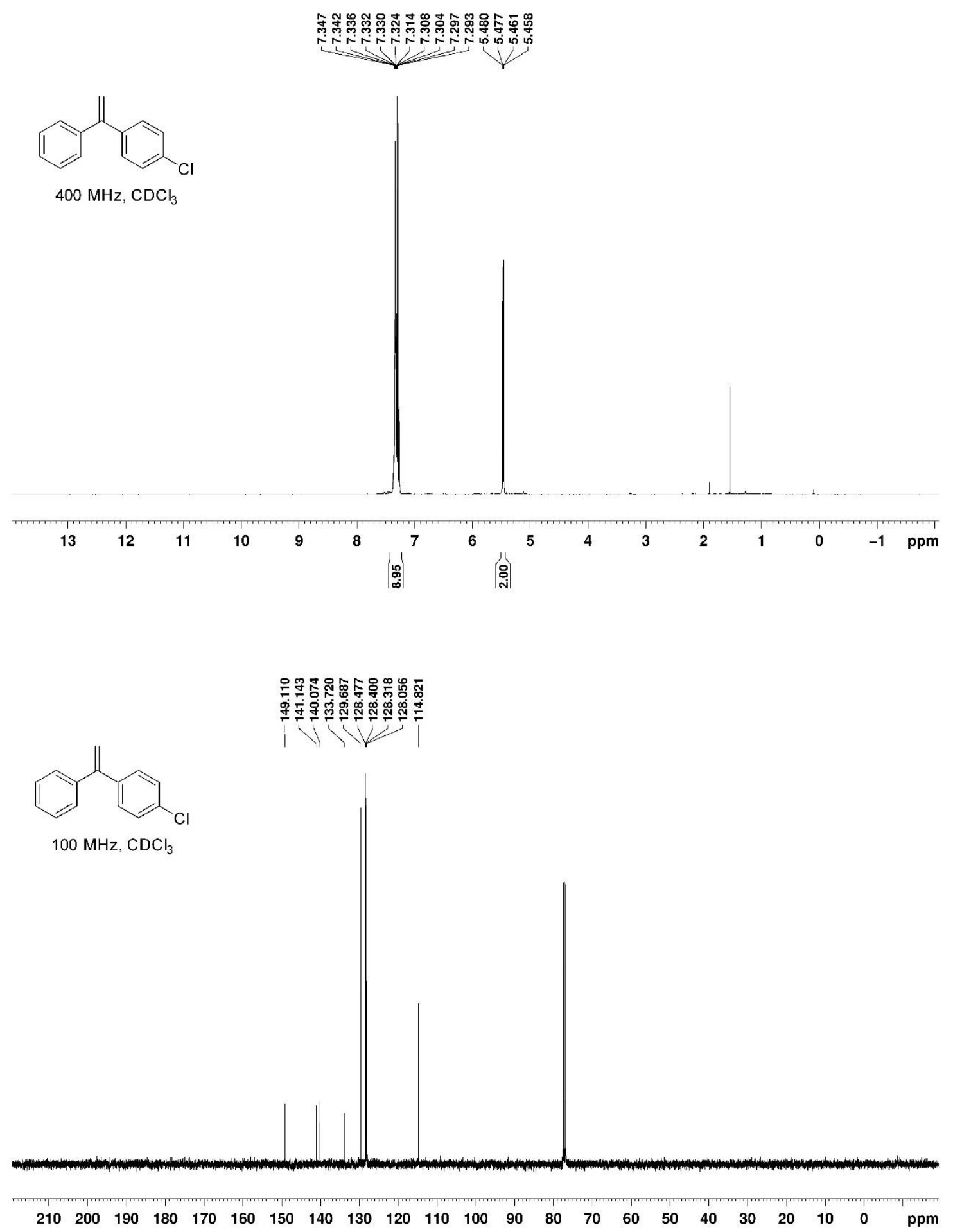
1-phenyl-1-(thiophen-3-yl)ethylene (2l)
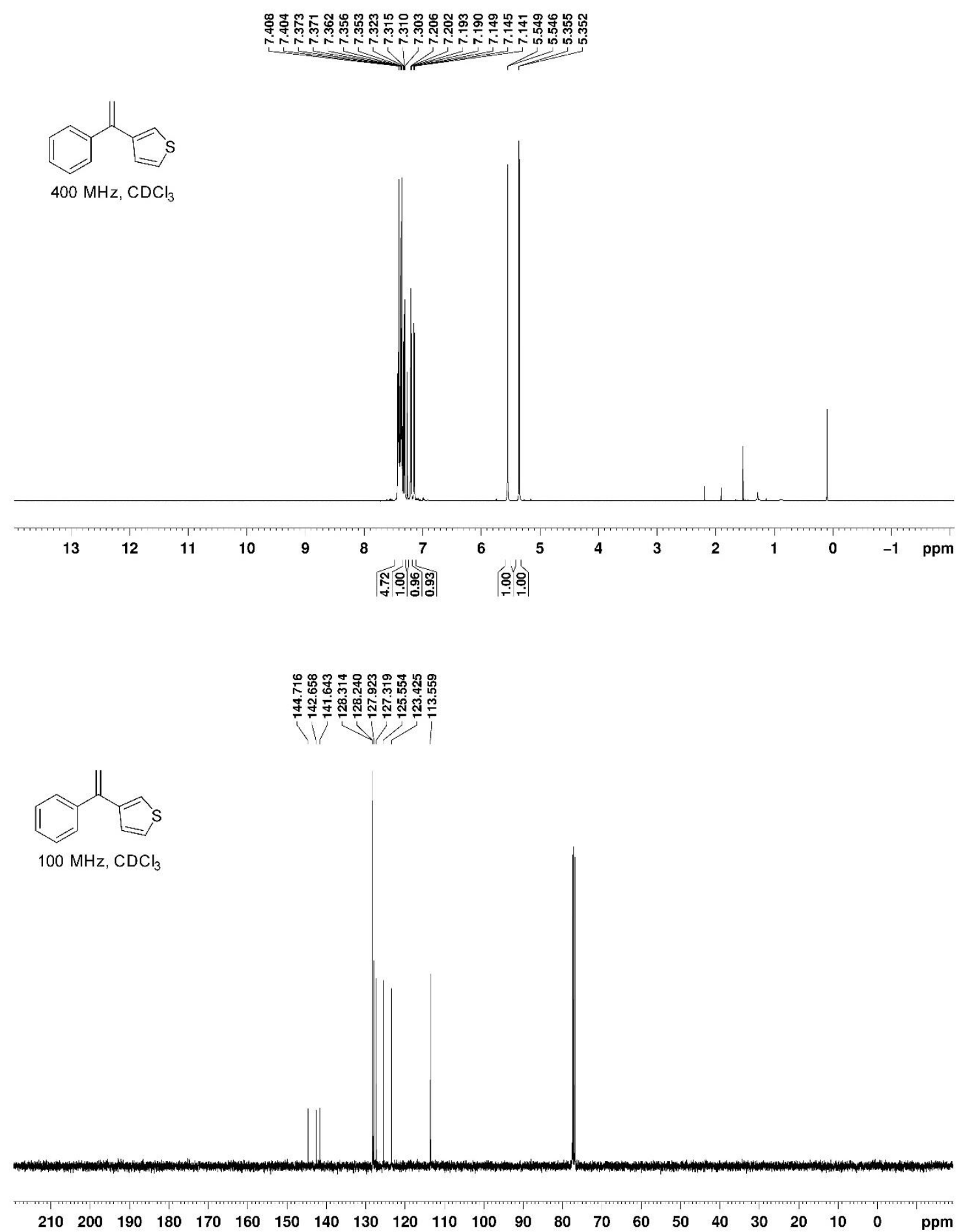
1-(5-methoxycarbonylfuran-2-yl)-1-phenylethylene (2m)

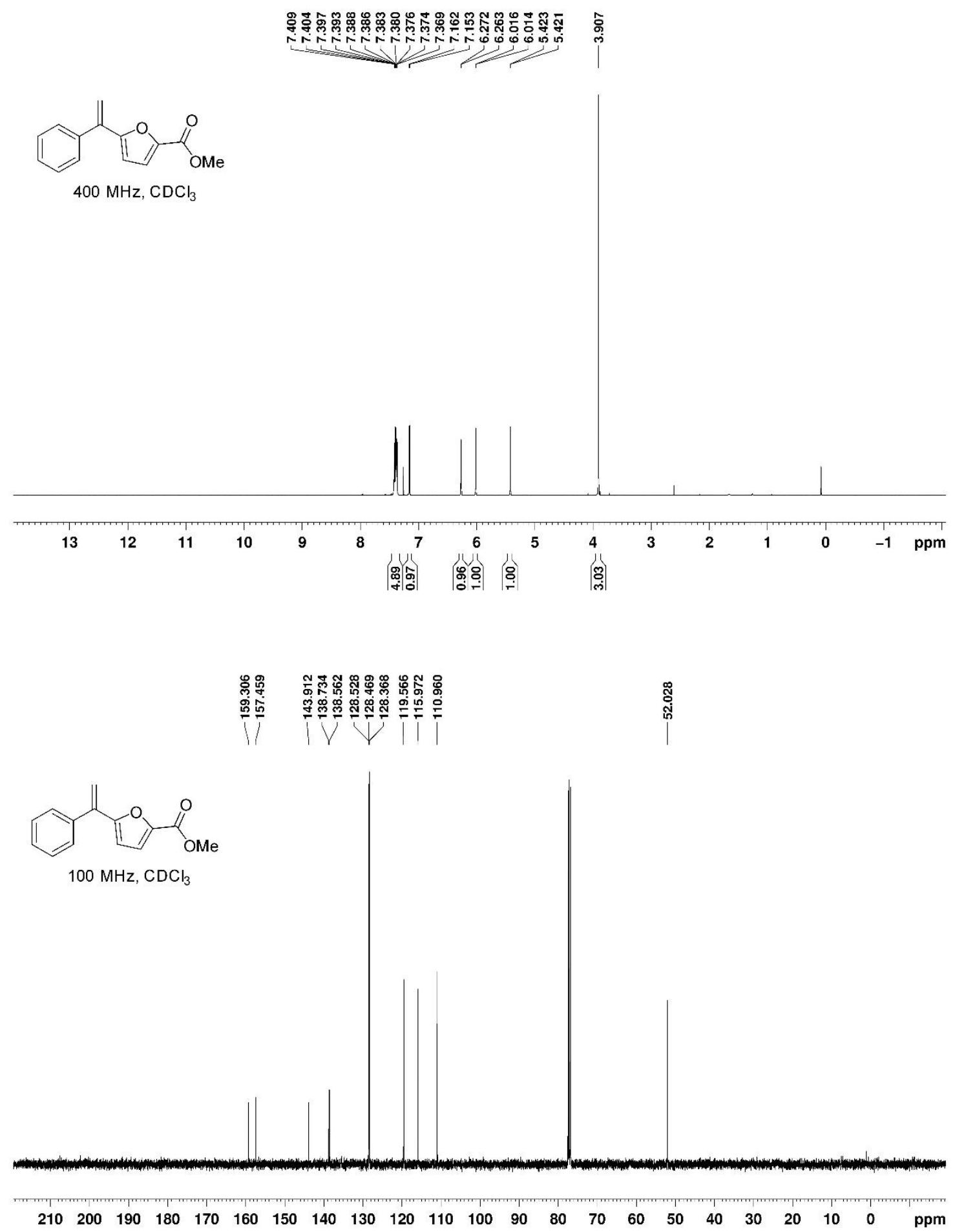


1-(indol-5-yl)-1-phenylethylene (2n)
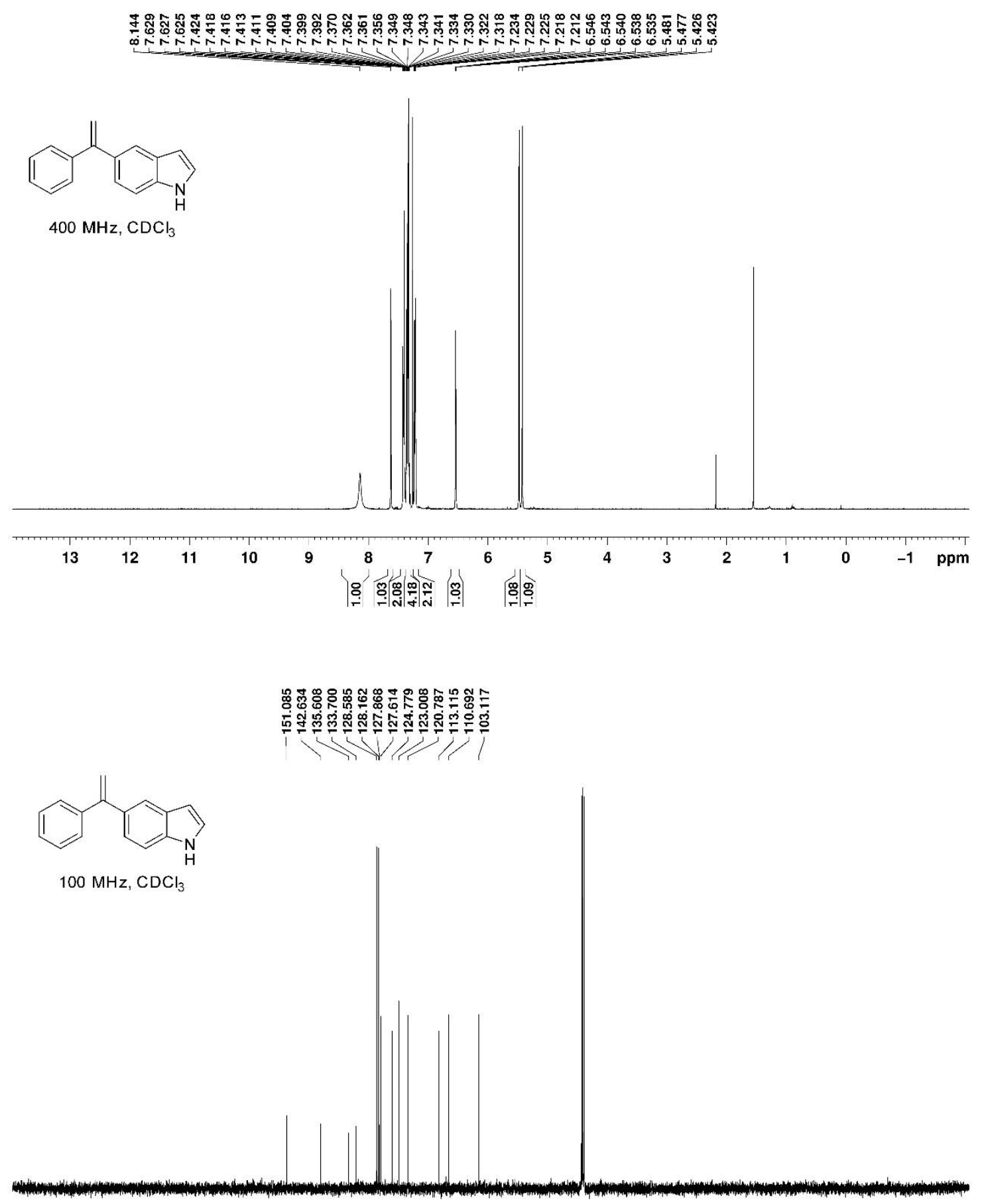

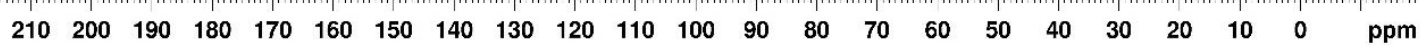


2-(2-oxindol-6-yl)-1-phenylethylene (2o)

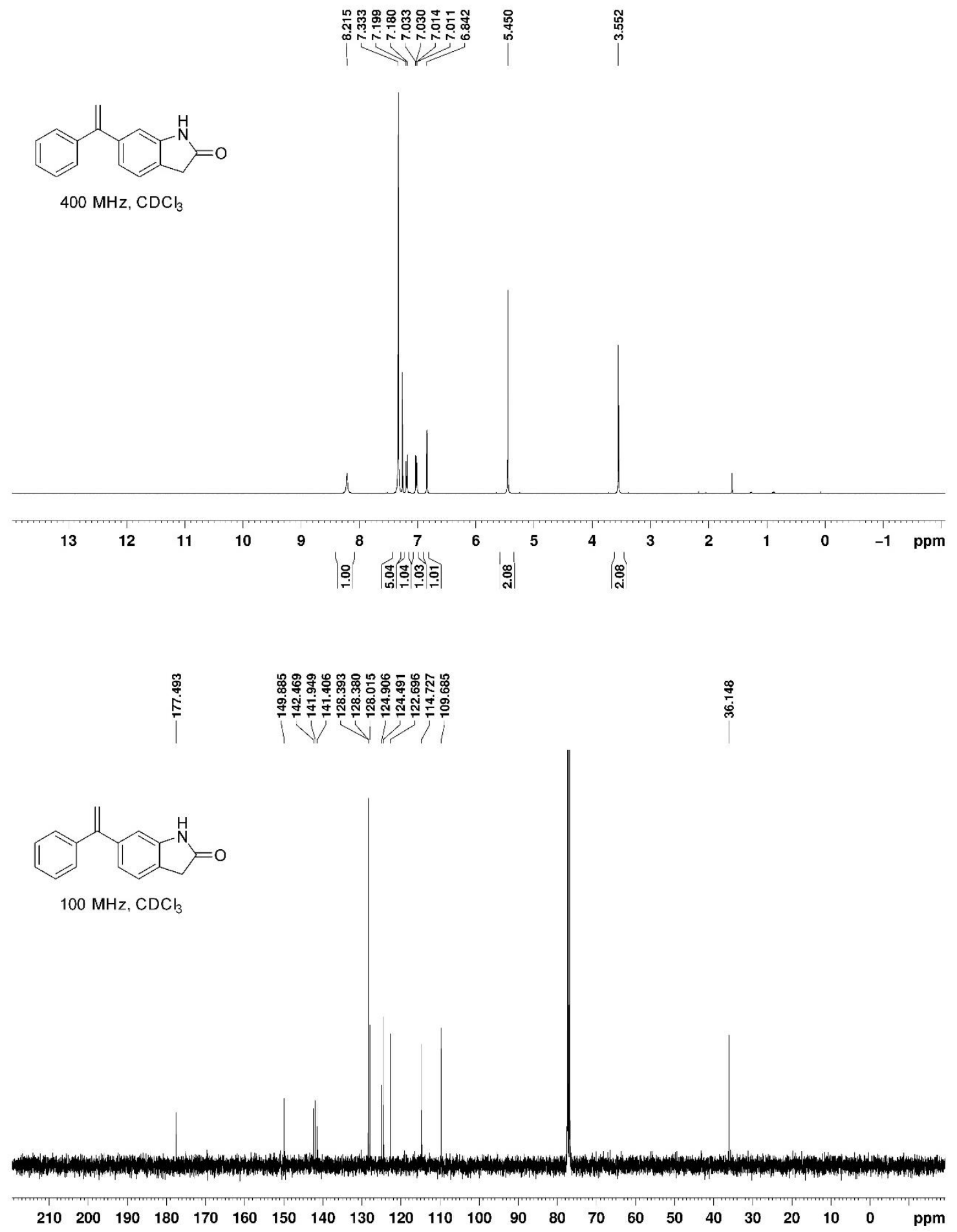


1-(indol-5-yl)-1-(2-naphthyl)ethylene (3a)

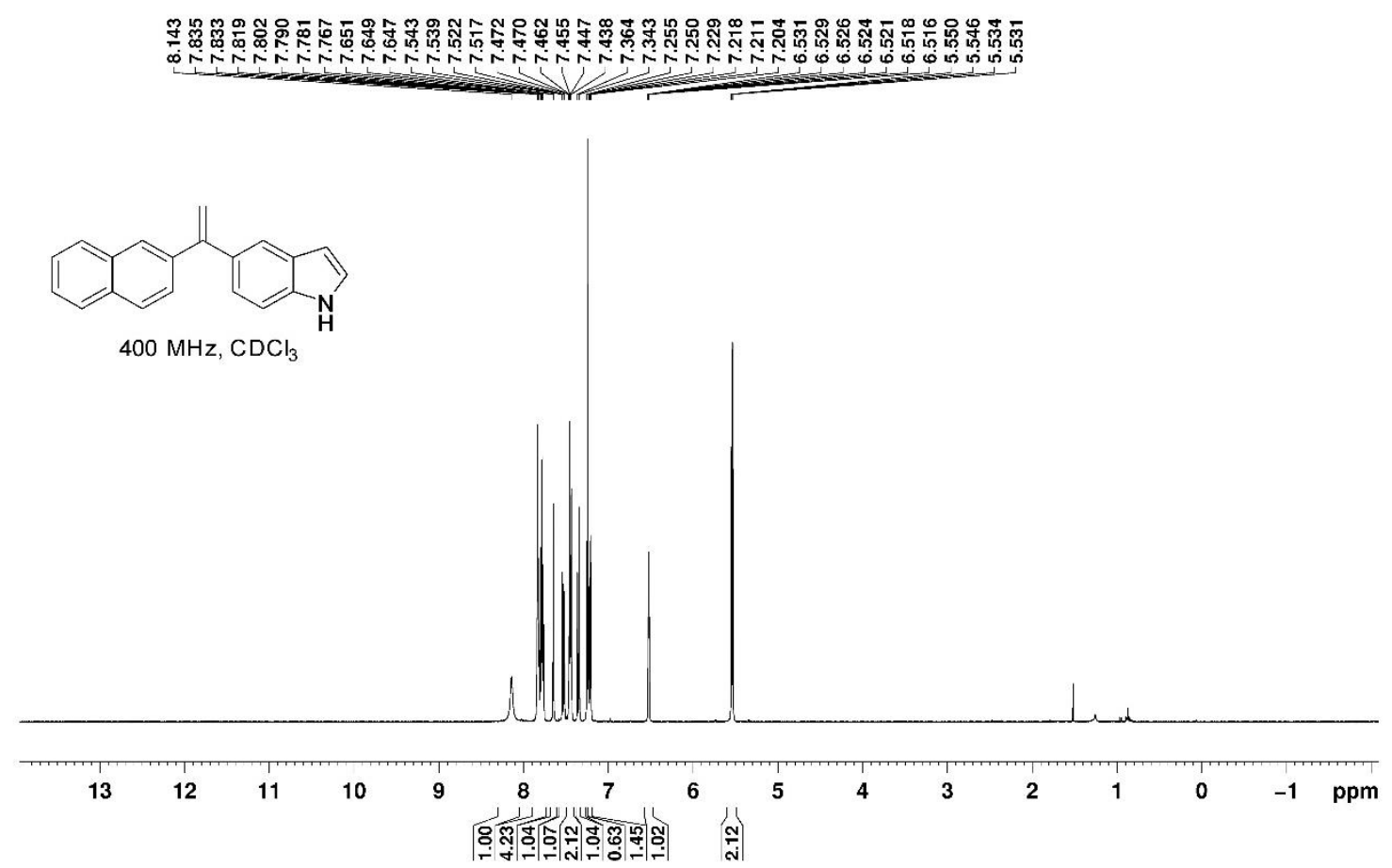

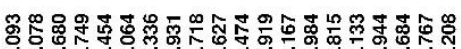

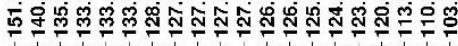

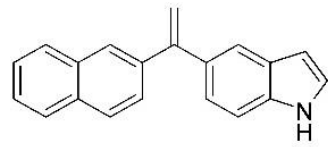

$100 \mathrm{MHz}, \mathrm{CDCl}_{3}$
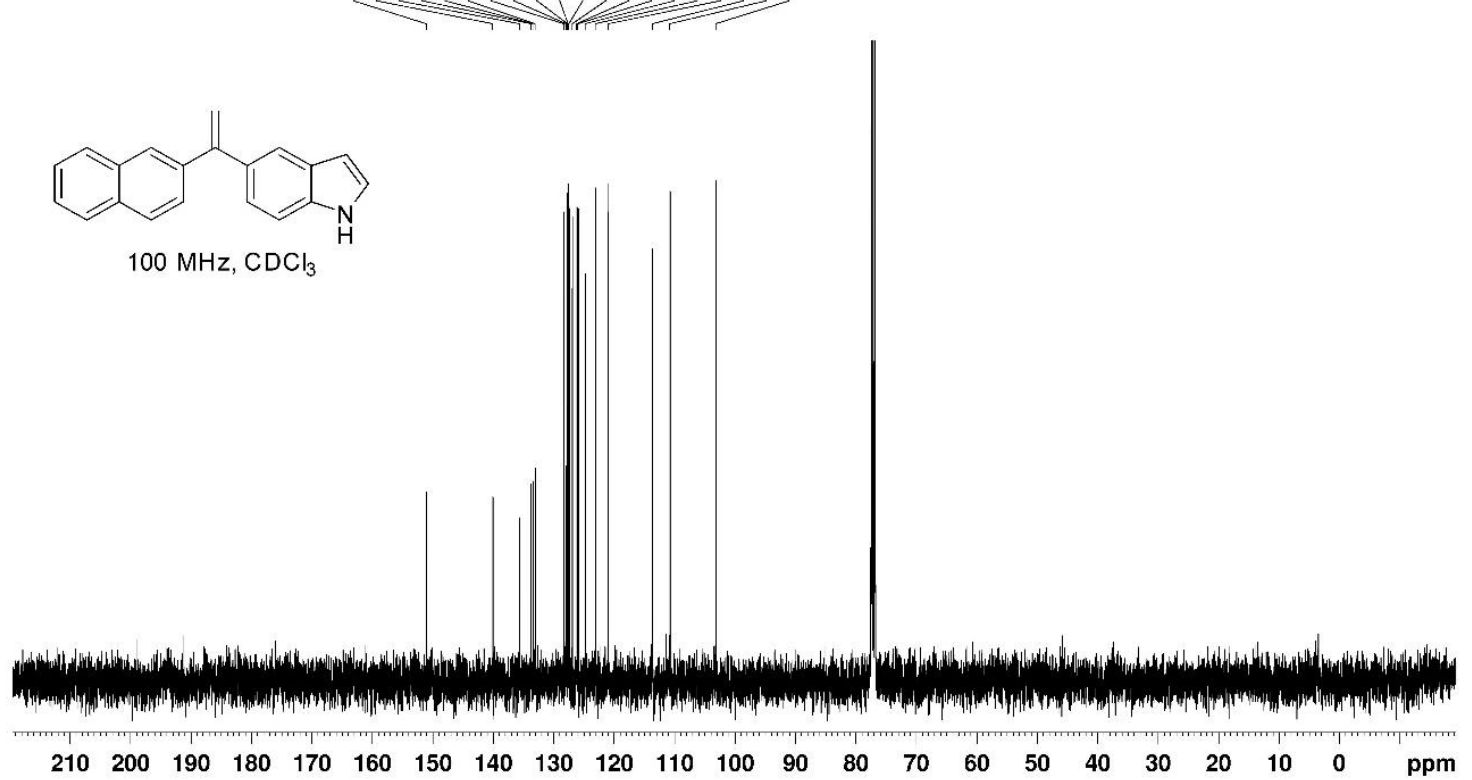
1-(indol-5-yl)-1-(4-methoxycarbonylphenyl)ethylene (3b)

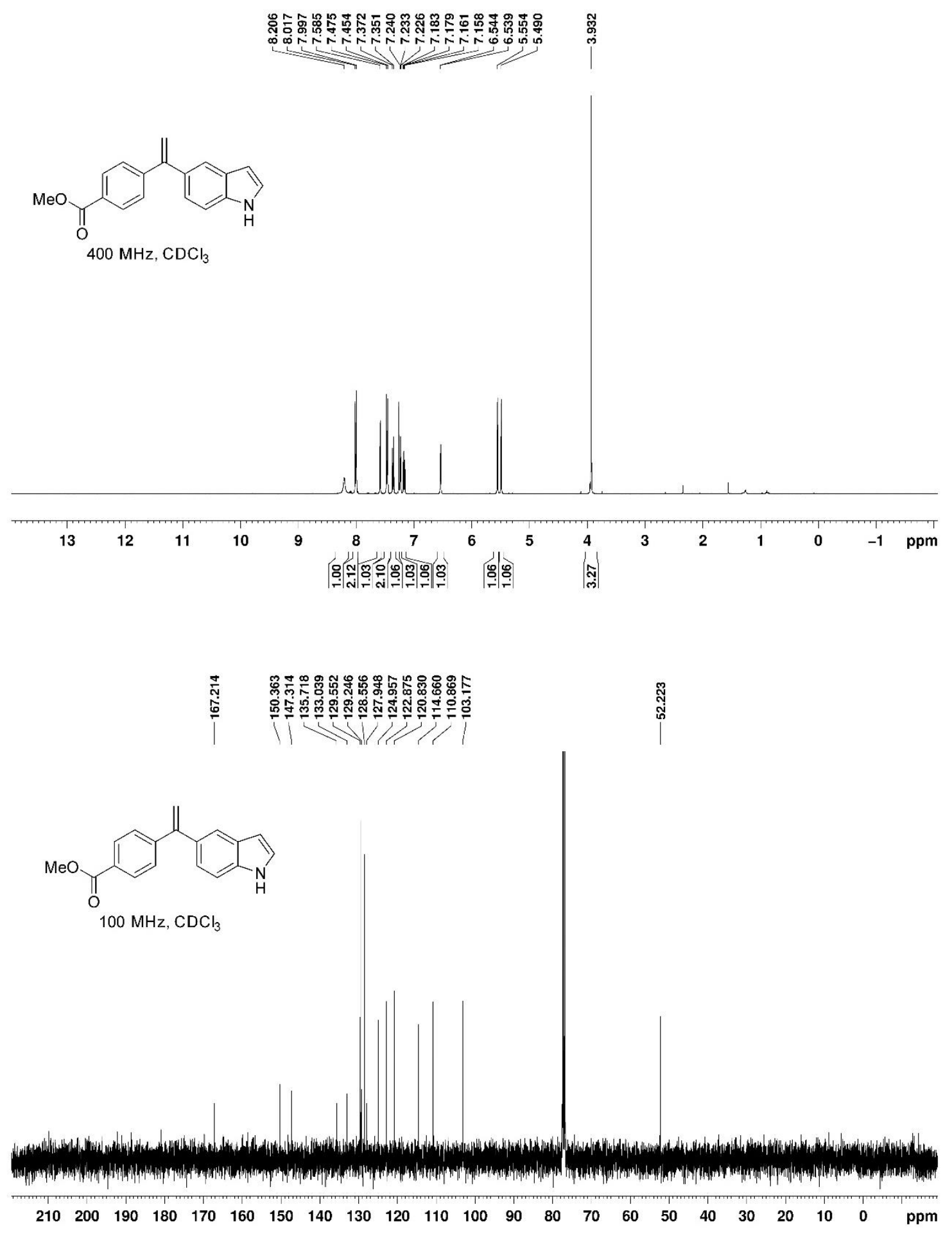


1-(indol-5-yl)-1-(4-methoxyphenyl)ethylene (3c)
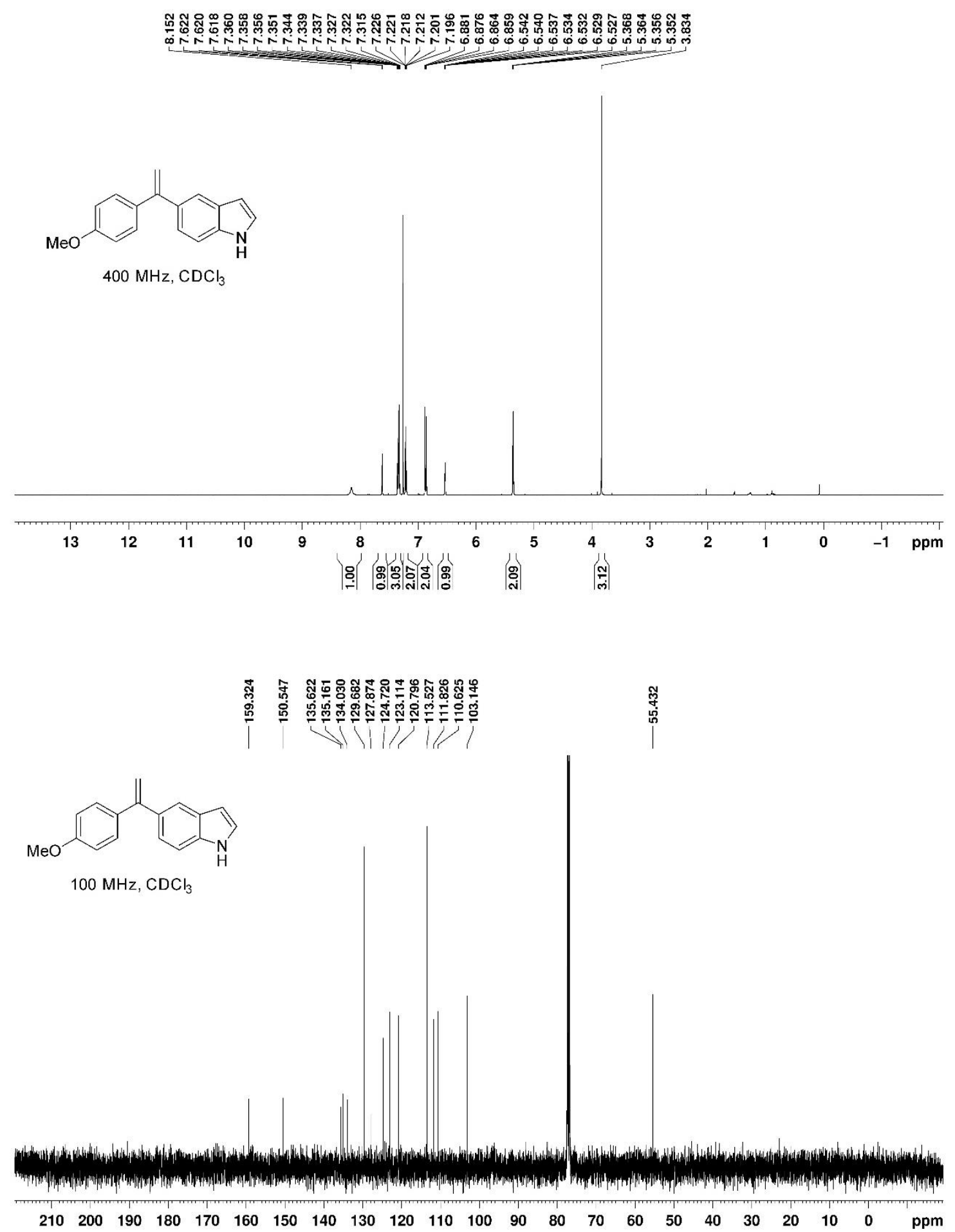
1-(indol-5-yl)-1-(2,4-dimethylphenyl)ethylene (3d)
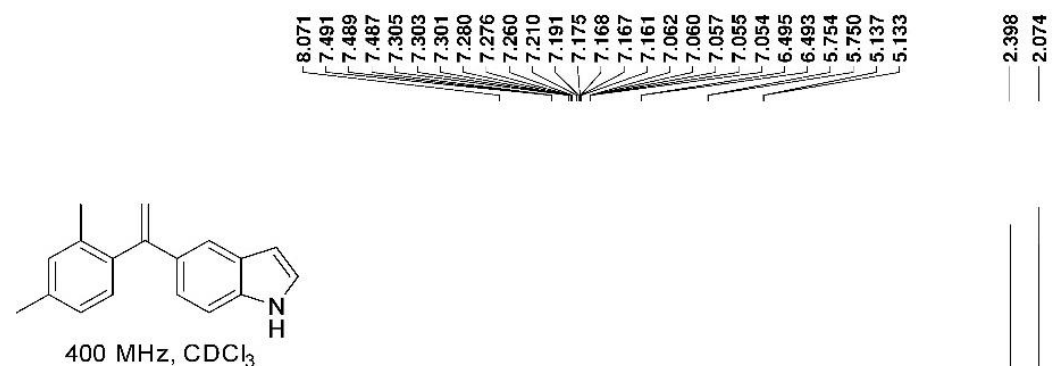

$400 \mathrm{MHz}, \mathrm{CDCl}_{3}$
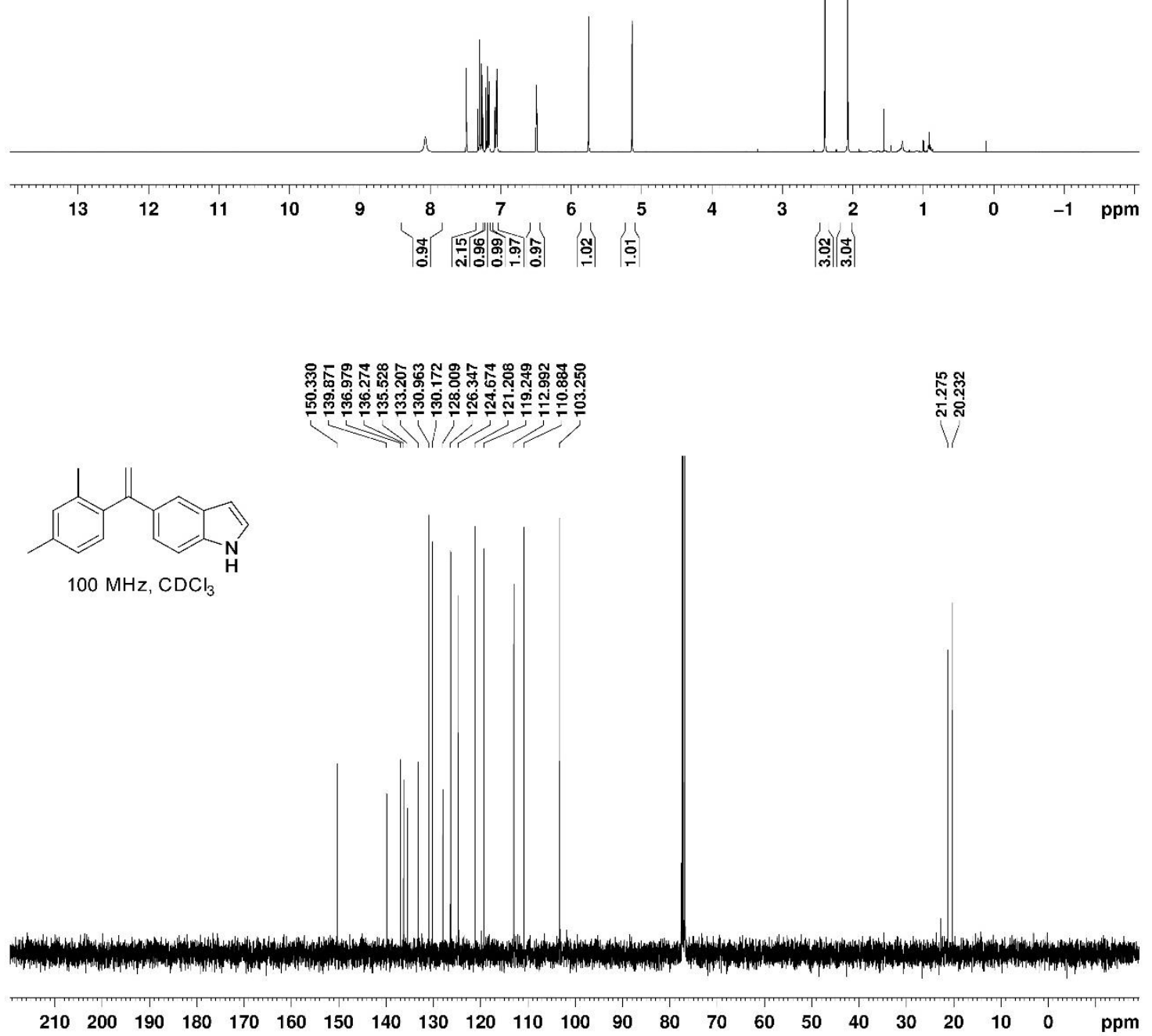
1-(indol-5-yl)-1-(thiophen-2-yl)ethylene (3e)
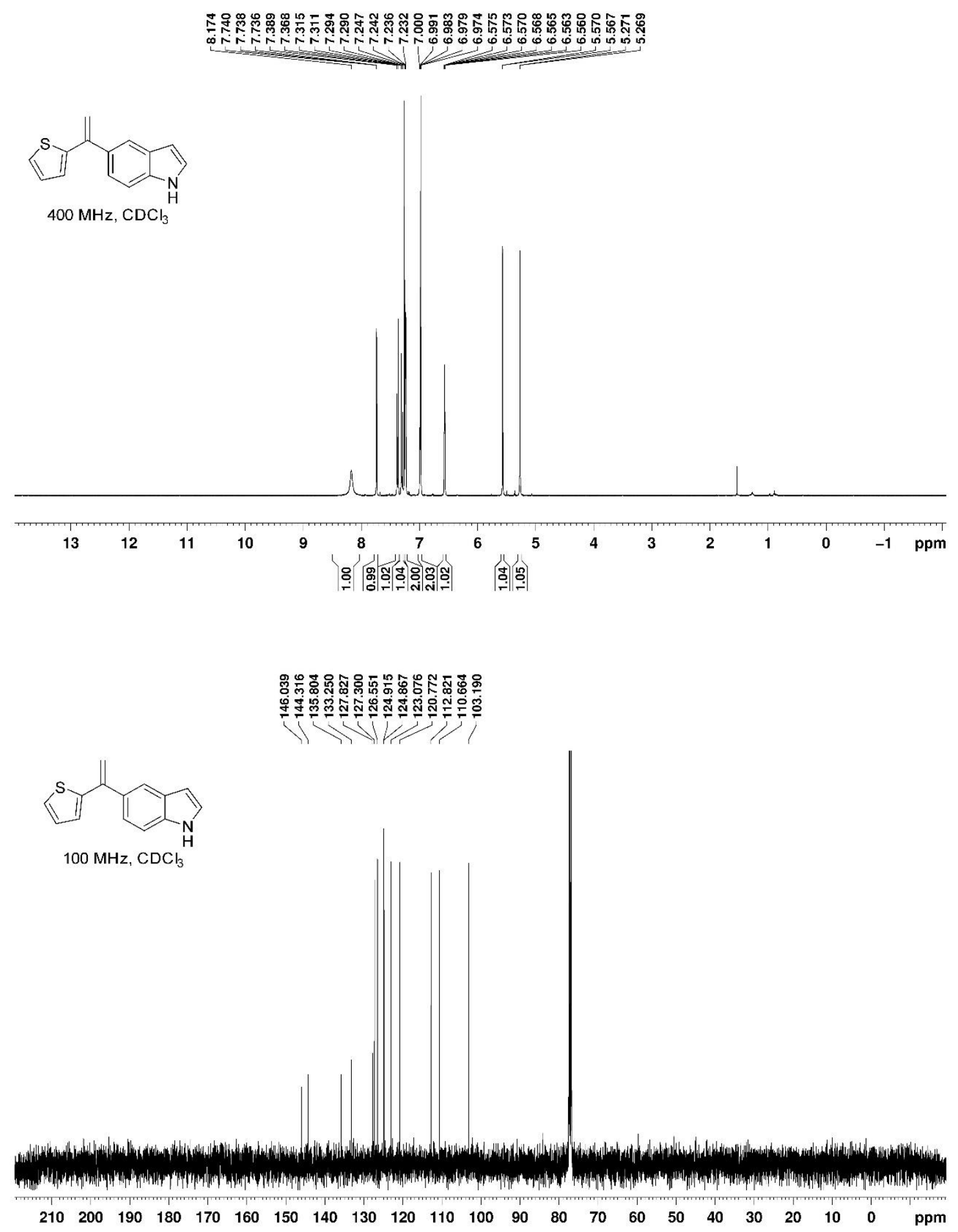
1-(indol-5-yl)-2-methyl-1-phenylprop-1-ene (3f)
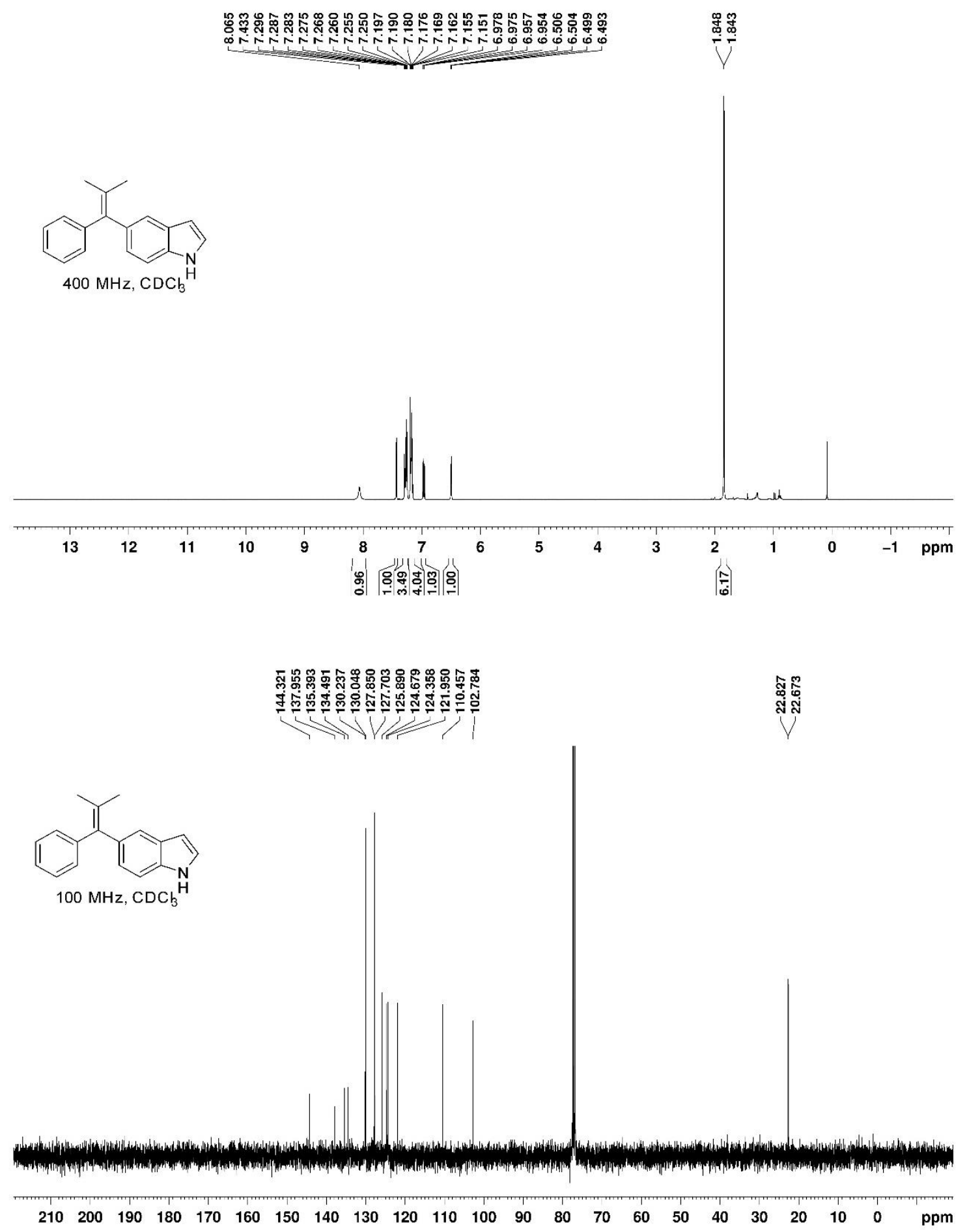
2-(indol-5-yl)-2-phenylmethylenecyclohexane (3g)
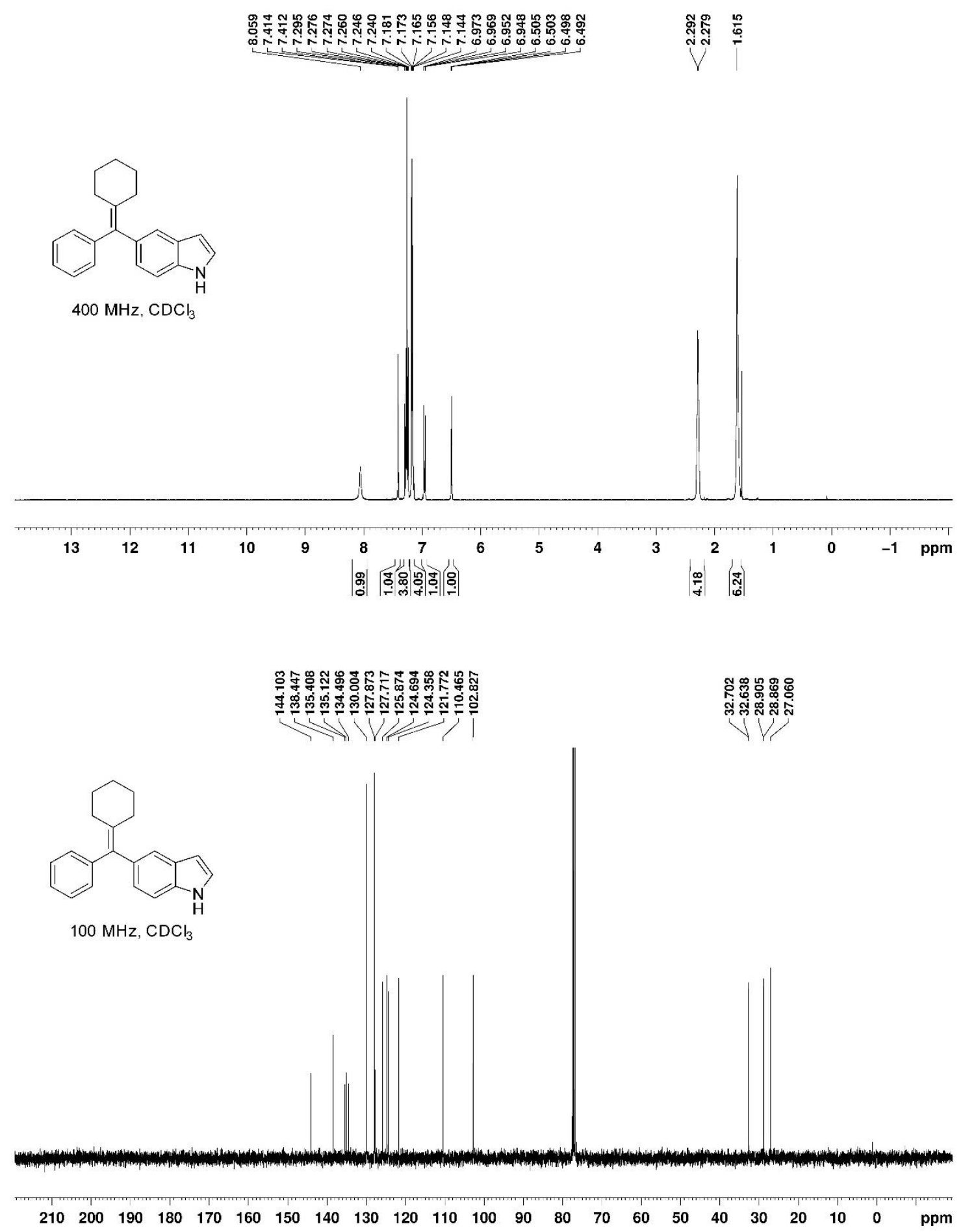
5-(2H-chromen-4-yl)indole (3h)
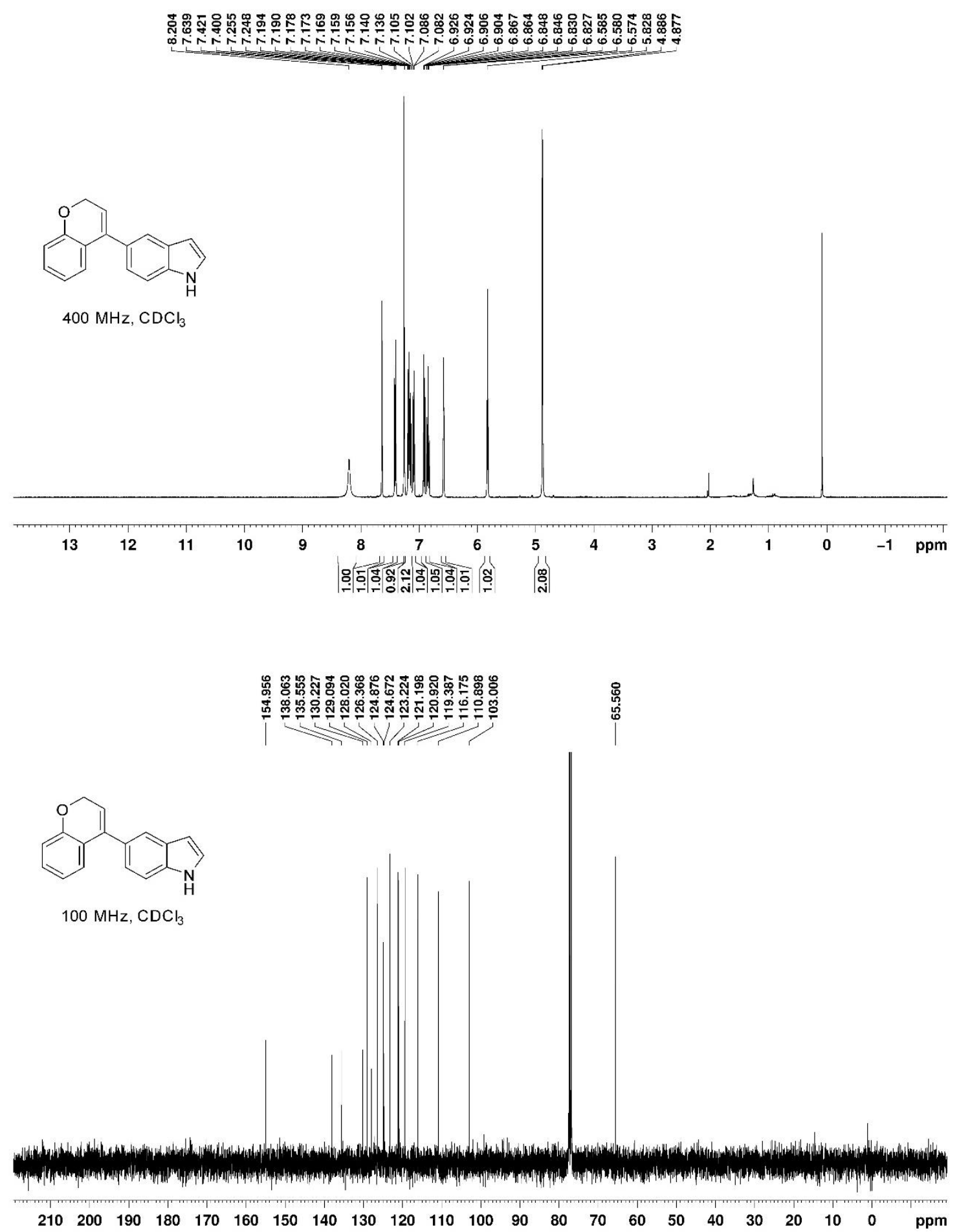
(Z)-1-(indol-5-yl)-1-(3-methoxyphenyl)prop-1-ene (3i isomer 1)

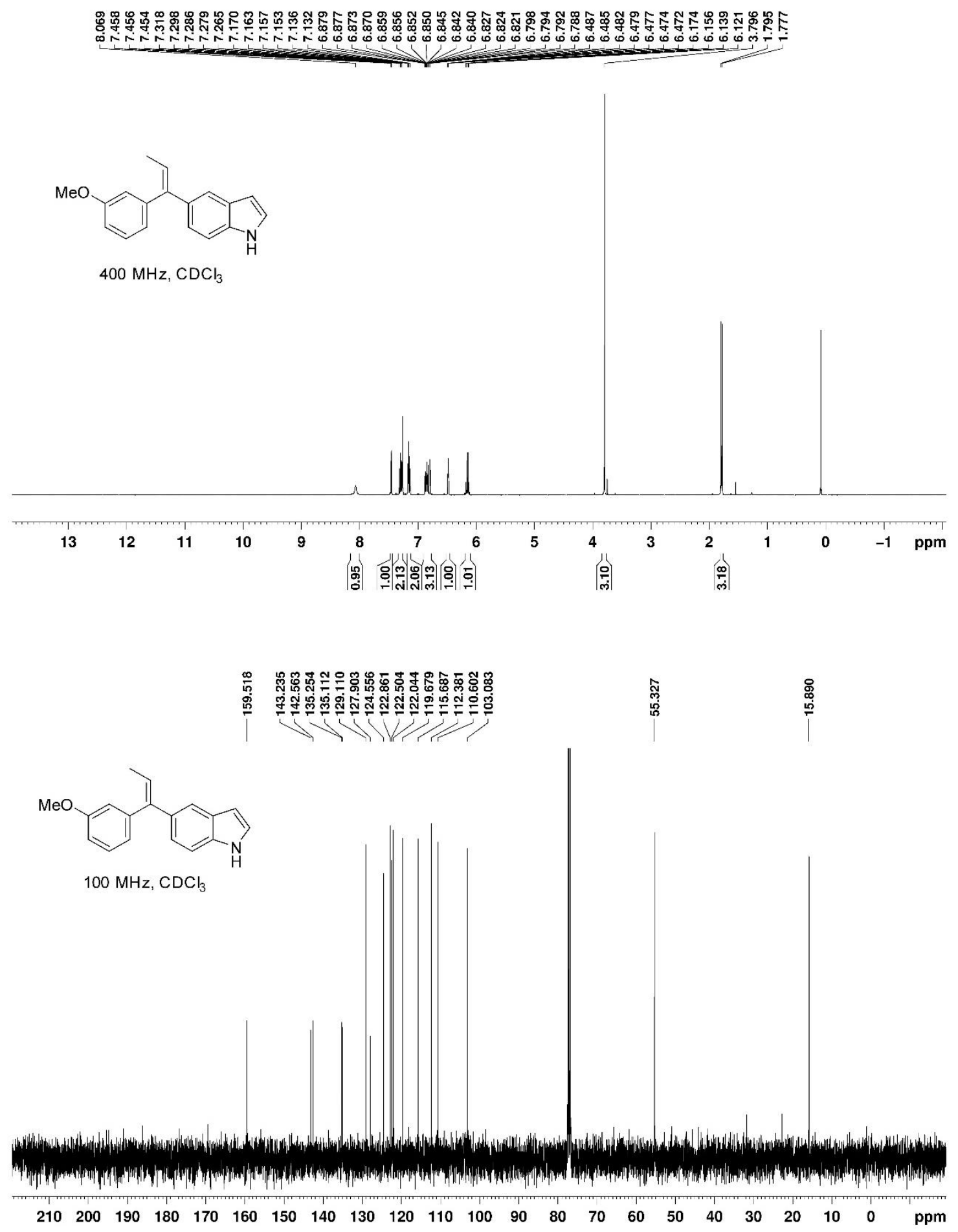


(E)-1-(indol-5-yl)-1-(3-methoxyphenyl)prop-1-ene (3i isomer 2)
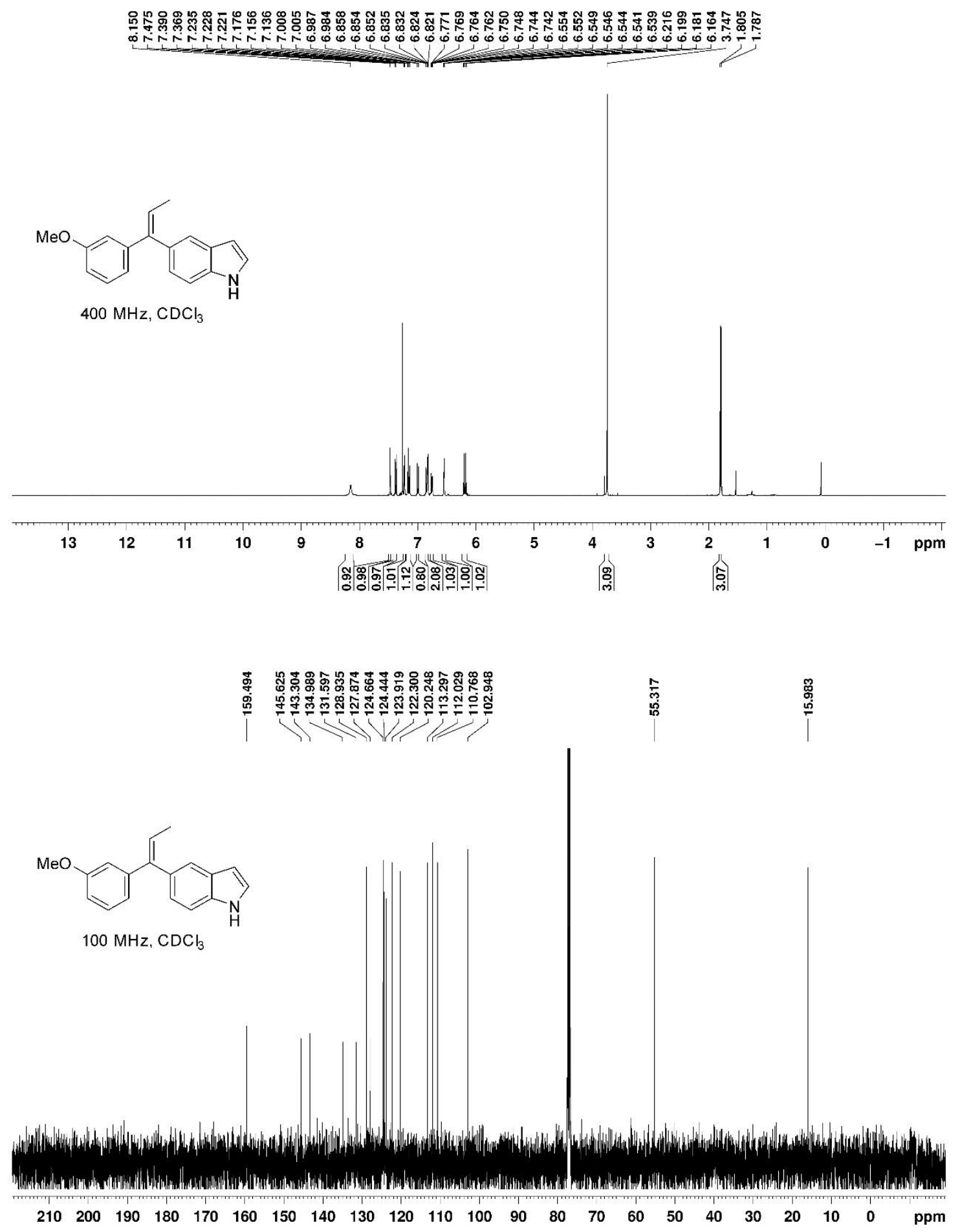
1-(4-cyanophenyl)-1-(thiophen-2-yl)ethylene (4a)

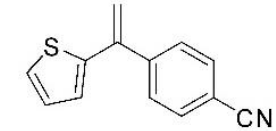

$400 \mathrm{MHz}, \mathrm{CDCl}_{3}$
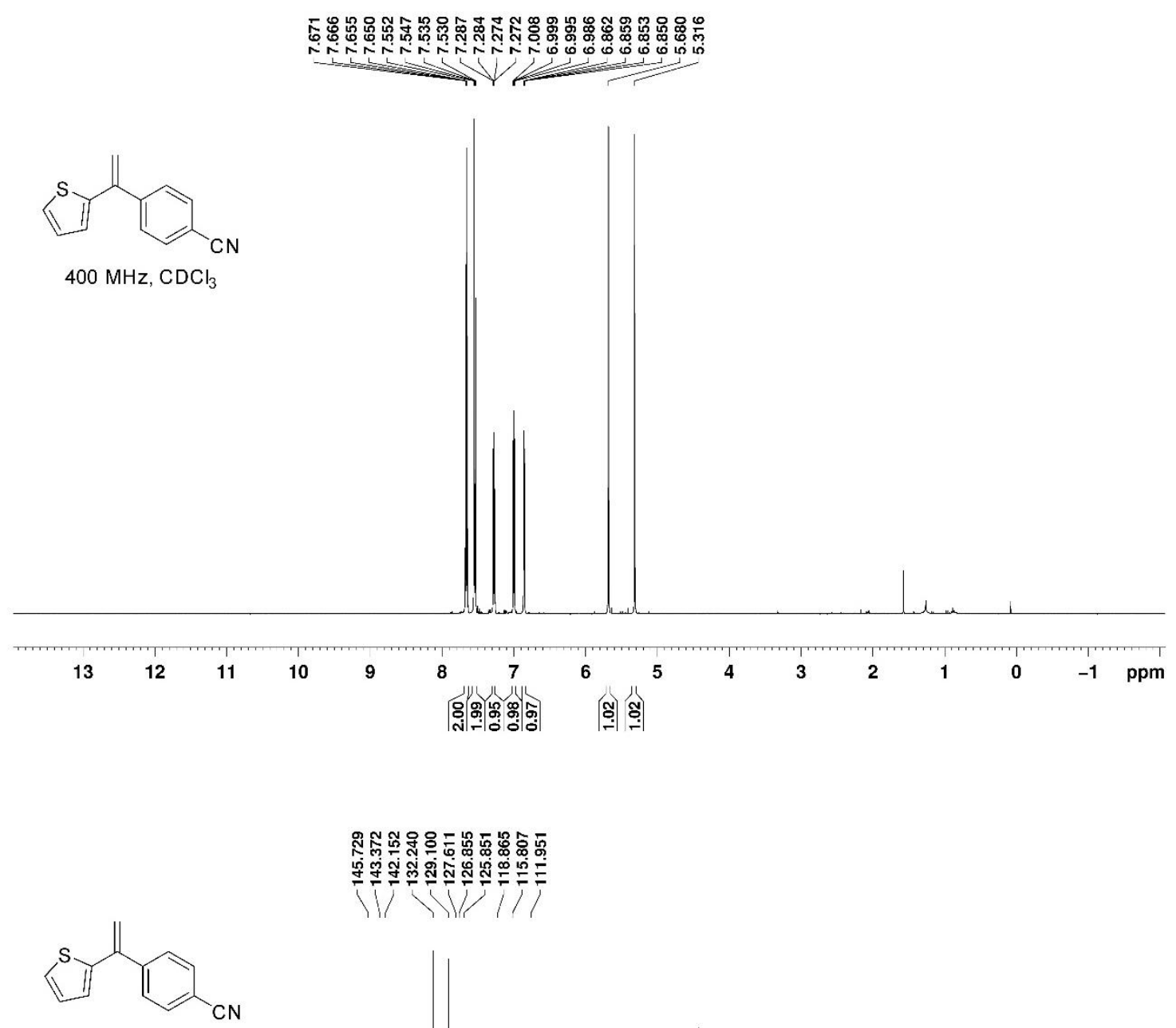

$100 \mathrm{MHz}, \mathrm{CDCl}_{3}$

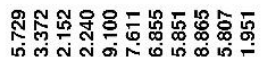

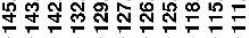

$11 / 1 / 1$

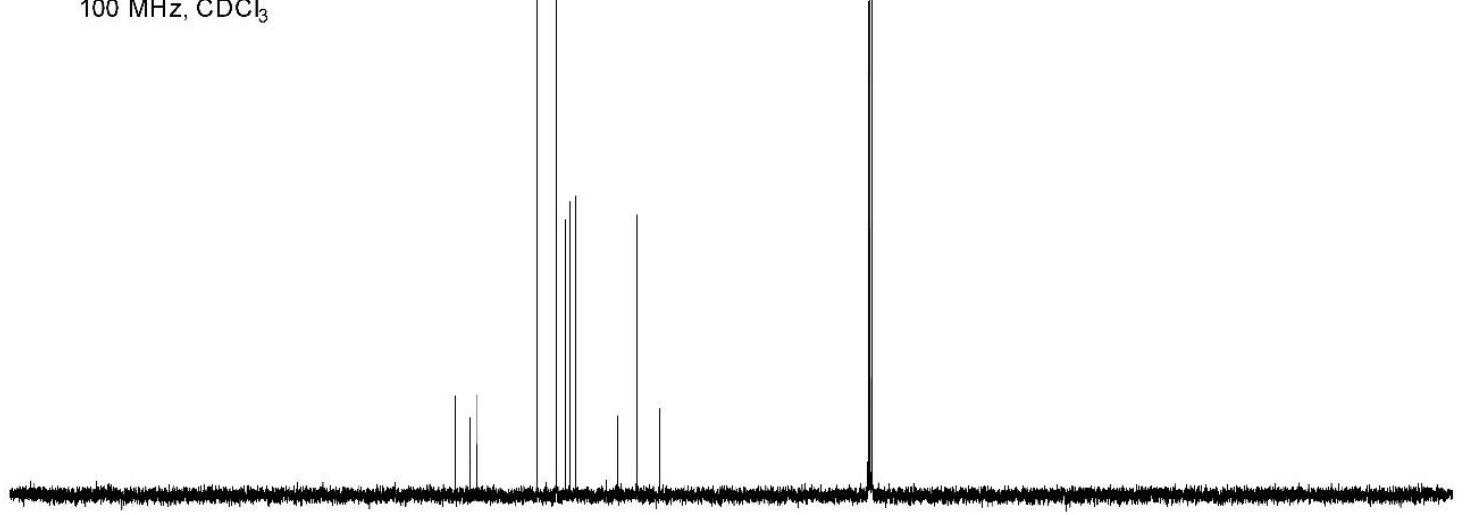

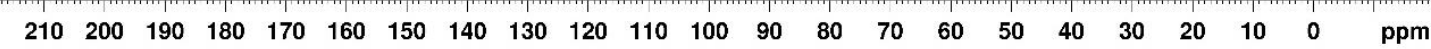


1-(benzophenone-4-yl)-1-(thiophen-2-yl)ethylene (4b)
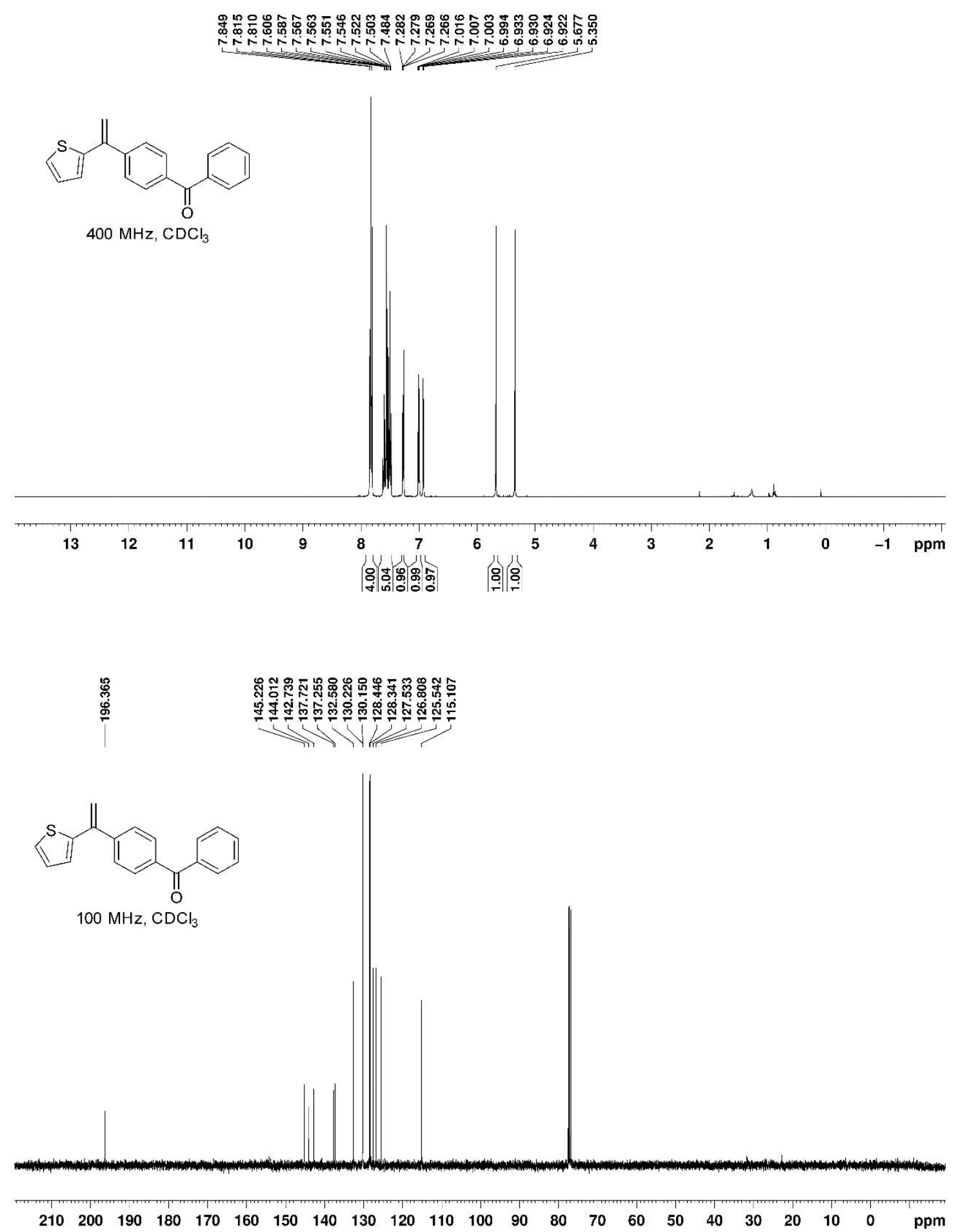
1-(4-methoxycarbonylphenyl)-1-(thiophen-2-yl)ethylene (4c)

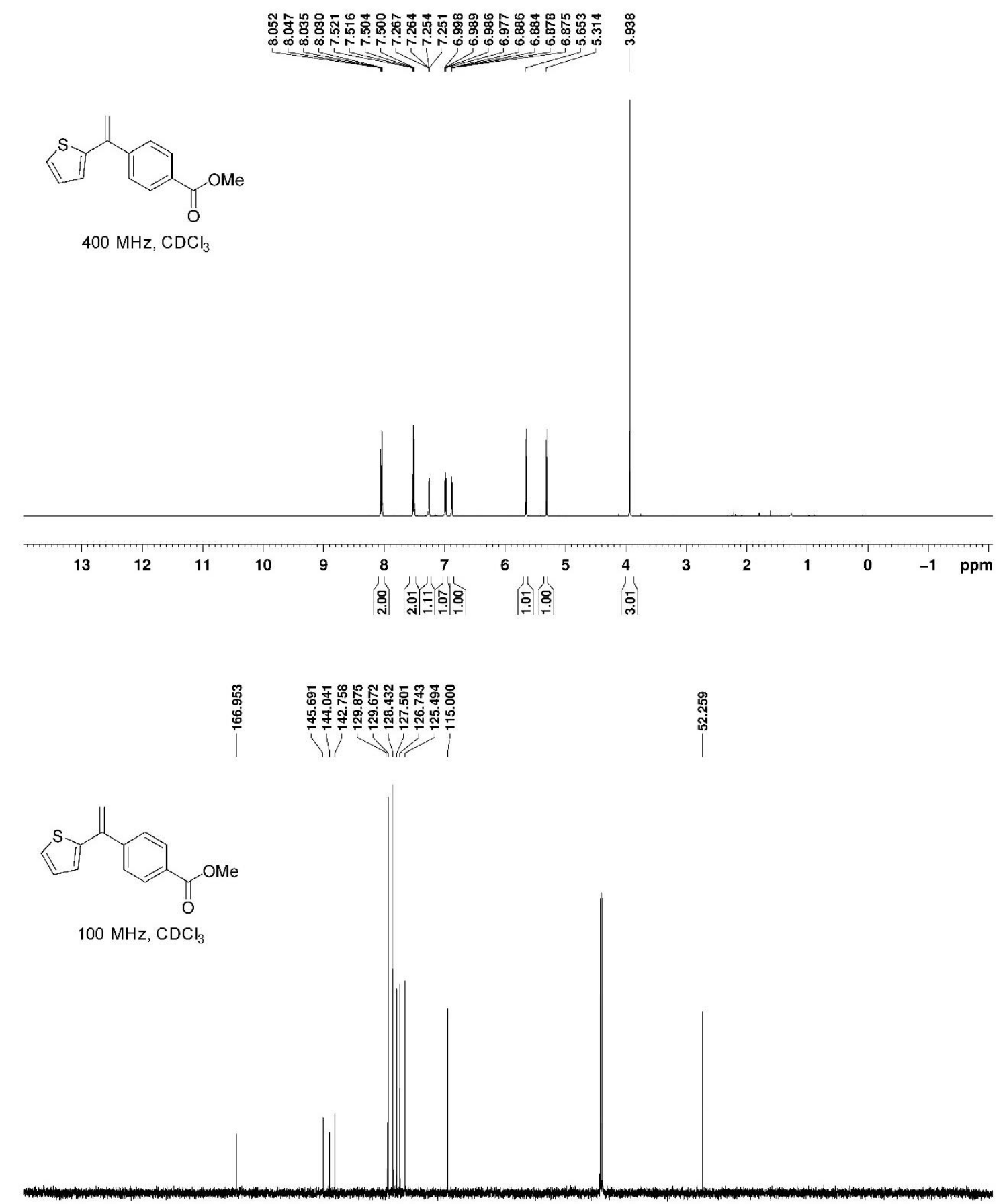

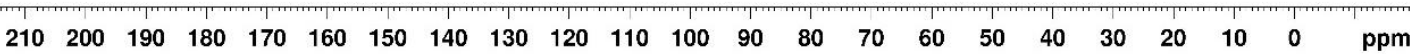


1-(4-morpholinylcarbonylphenyl)-1-(thiophen-2-yl)ethylene (4d)

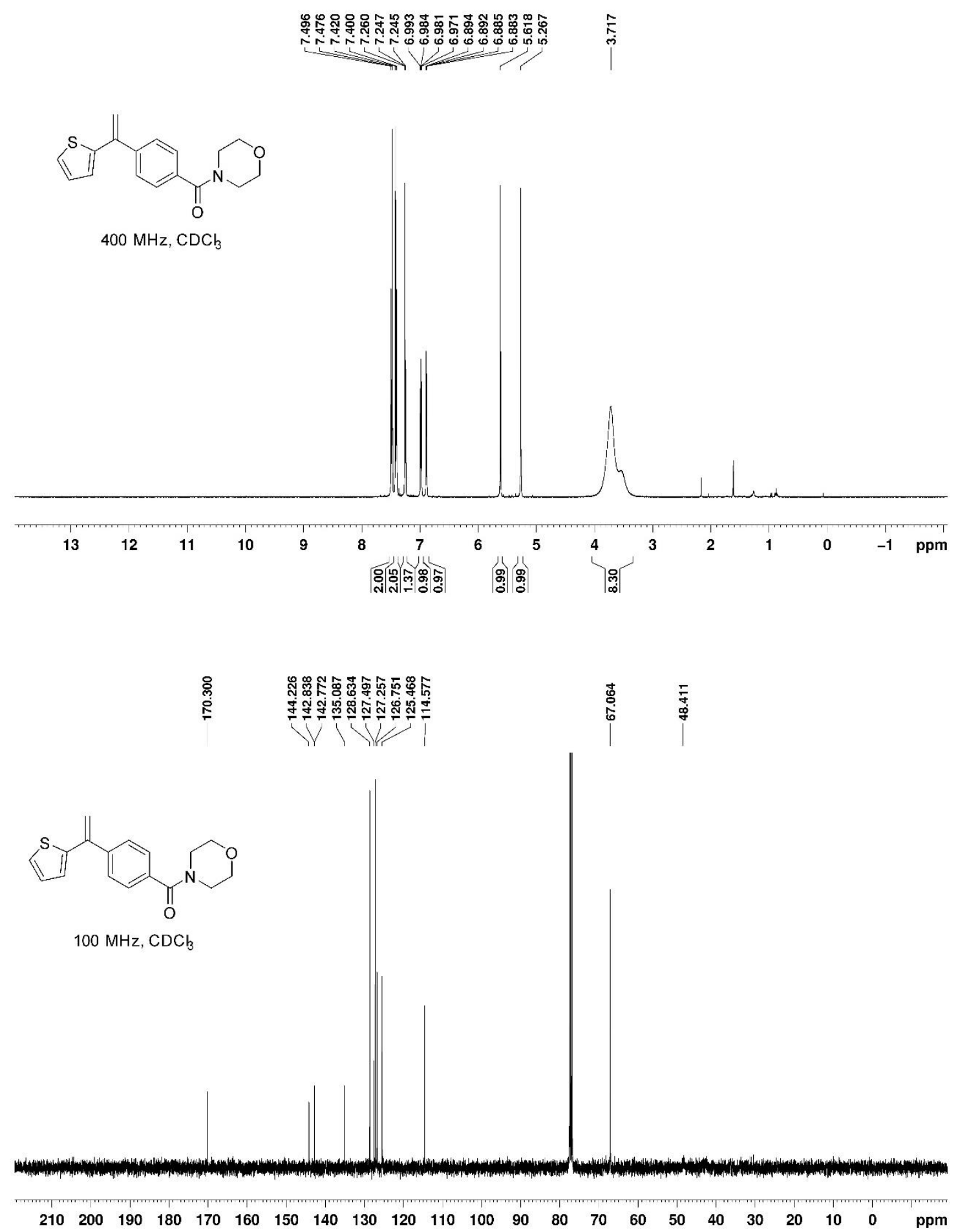


1-(4-nitrophenyl)-1-(thiophen-2-yl)ethylene (4e)
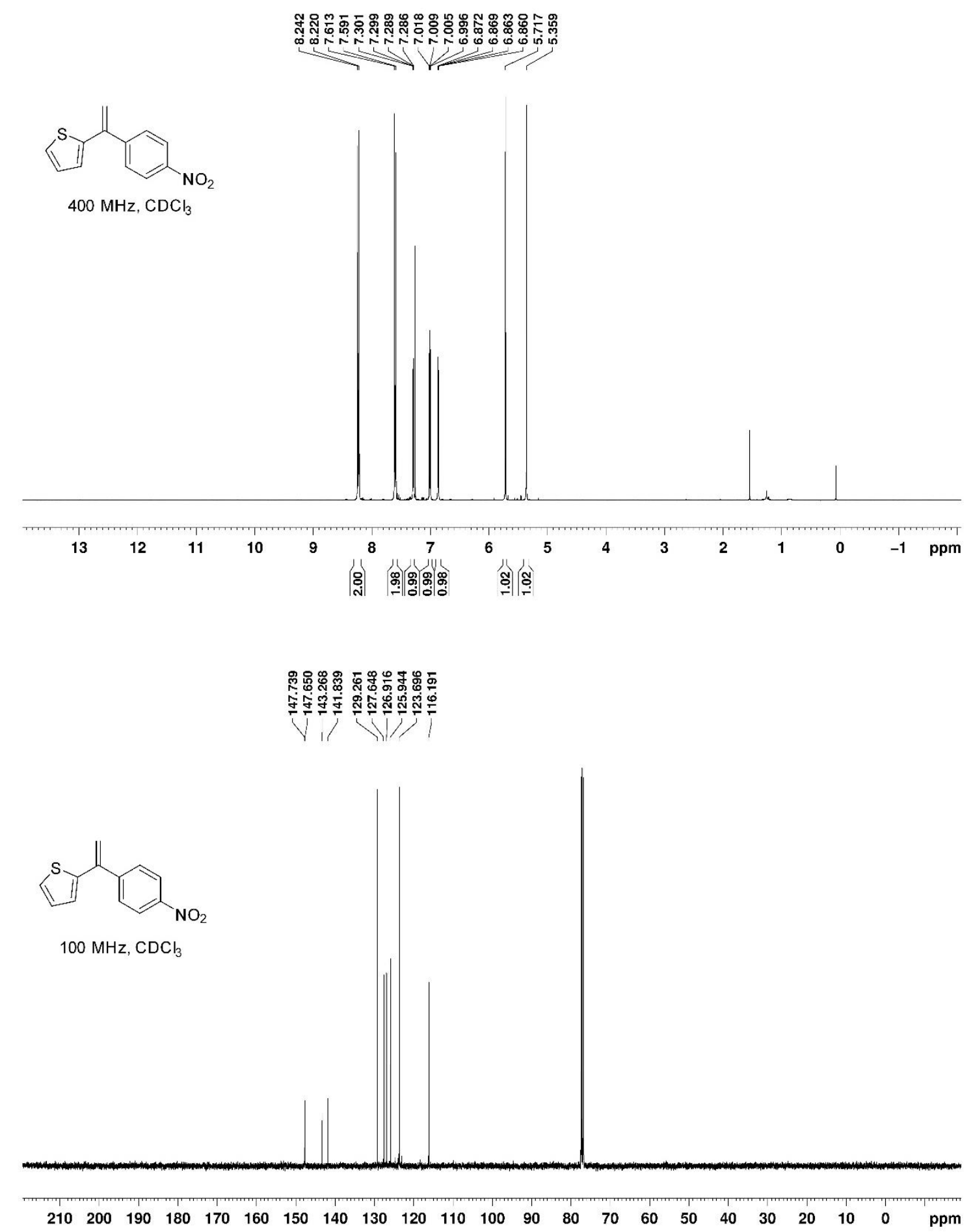
1-(4-methyl-3-nitrophenyl)-1-(thiophen-2-yl)ethylene (4f)
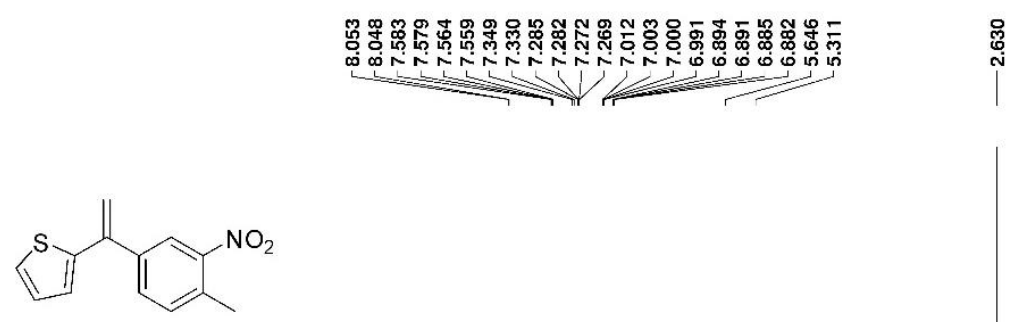

$400 \mathrm{MHz} \mathrm{CDCl}_{3}$
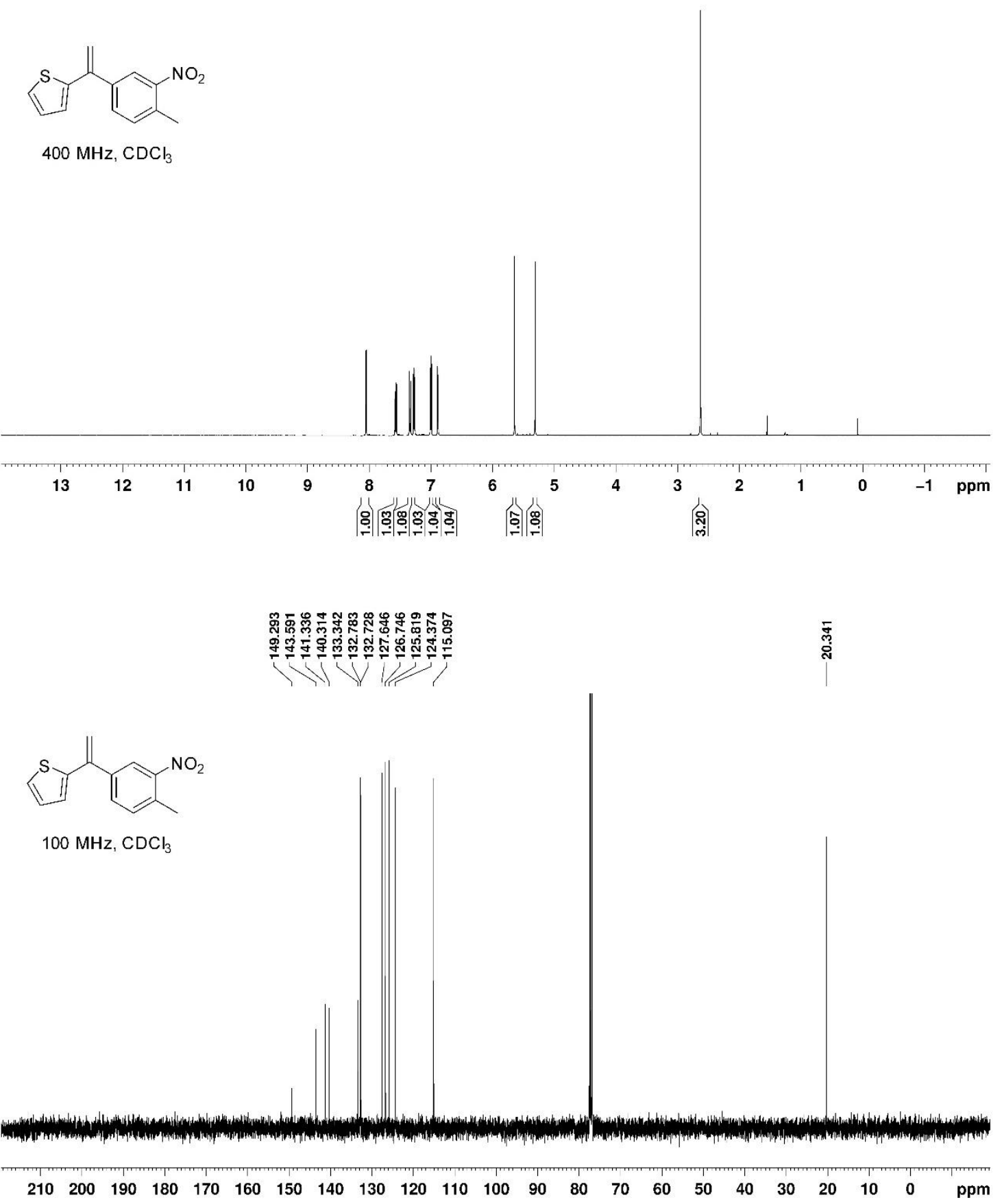


\section{Energies of calculated structures}

Table S3. Energies (in Hartree) for all organic and organometallic compounds and transition states: $\mathrm{E}_{\mathrm{DZ}}$ and thermal corrections were calculated at the M06-L/def2-SVP level of theory; $\mathrm{E}_{\mathrm{TZ}}$ single point energy calculations were performed on the M06-L/def2-SVP geometries at the M06-L/def2-TZVP level of theory with incorporation of solvation energy using the continuous polarization model for toluene.

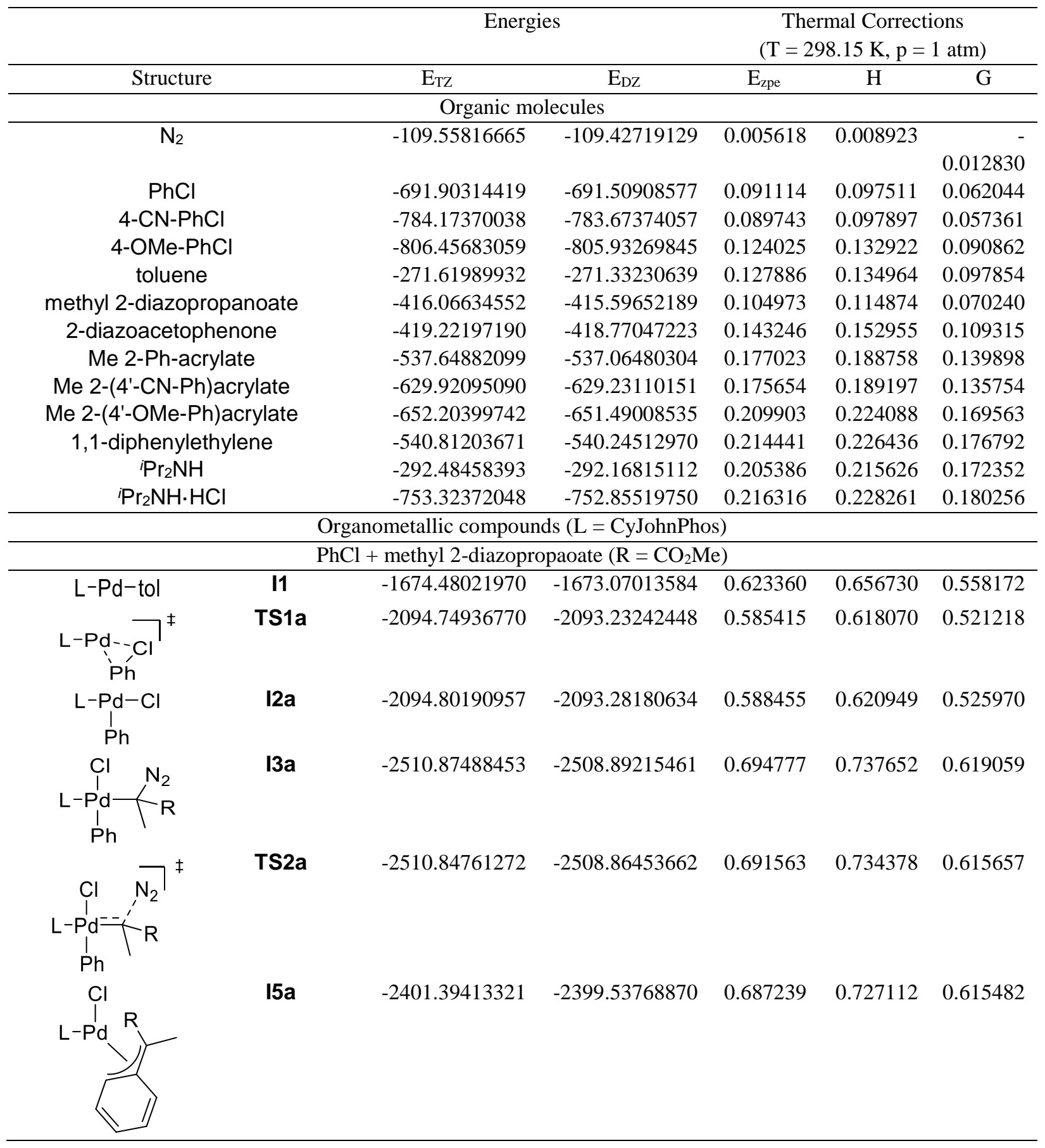




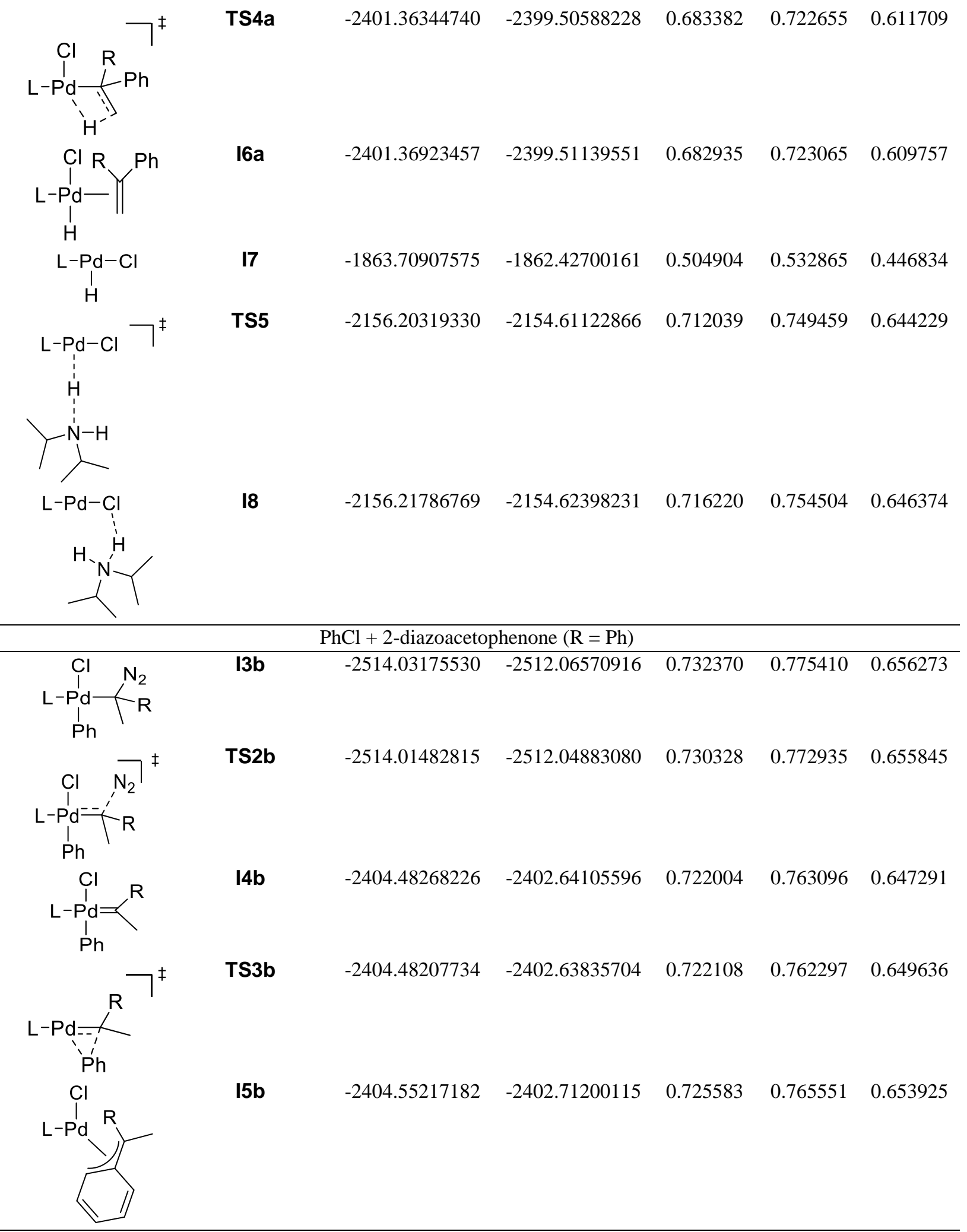



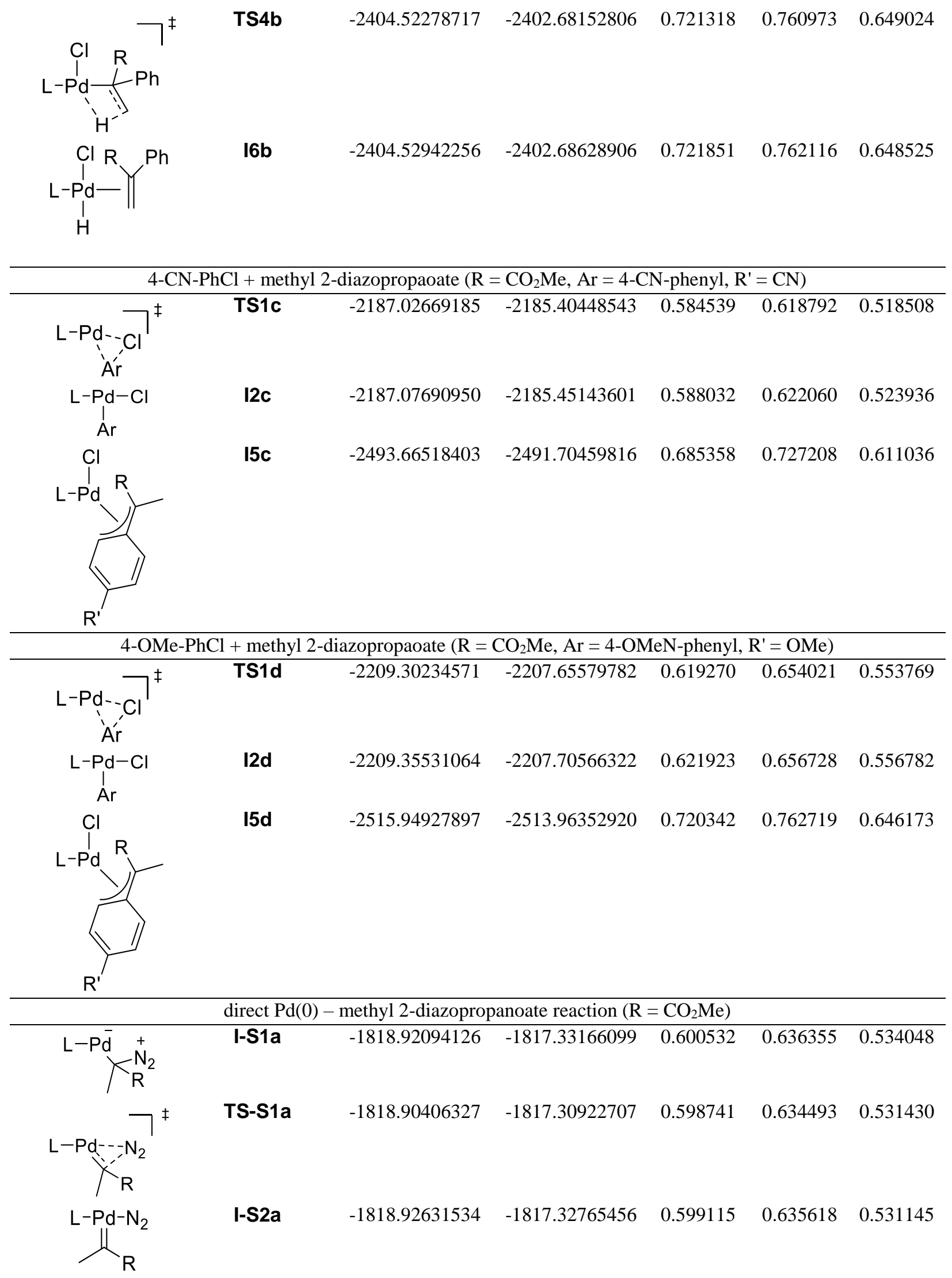


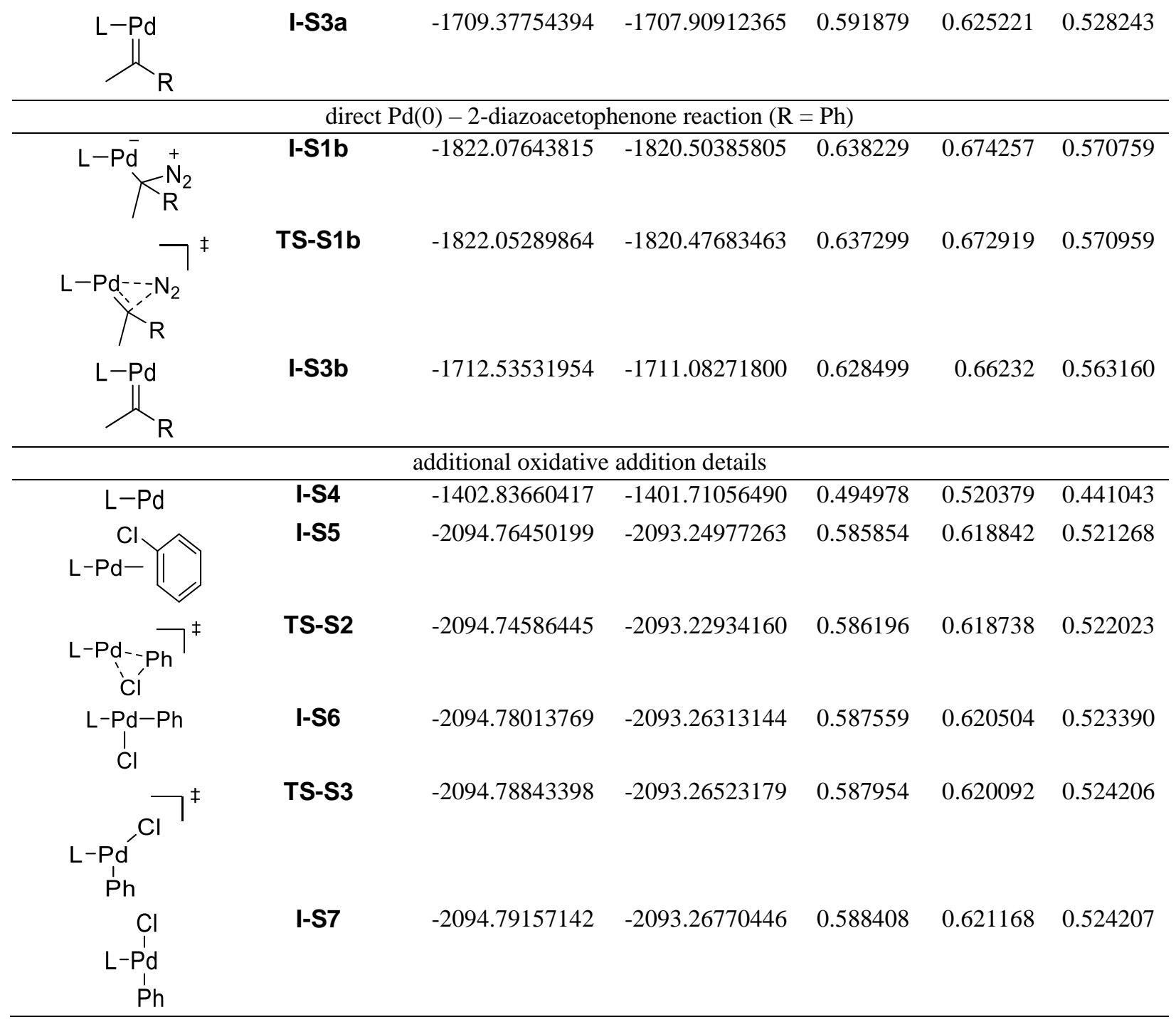




\section{Cartesian coordinates of calculated structures}

$\mathrm{N}_{2}$

\begin{tabular}{cccc}
\hline Atom & $\mathrm{x}$ & $\mathrm{y}$ & $\mathrm{z}$ \\
\hline $\mathrm{N}$ & 0 & 0 & 0.552249 \\
$\mathrm{~N}$ & 0 & 0 & -0.55225 \\
\hline
\end{tabular}

$\mathrm{PhCl}$

\begin{tabular}{cccc}
\hline Atom & $\mathrm{x}$ & $\mathrm{y}$ & $\mathrm{z}$ \\
\hline $\mathrm{C}$ & 0 & 0 & -2.26801 \\
$\mathrm{C}$ & 0 & 1.205812 & -1.56778 \\
$\mathrm{C}$ & 0 & 1.214893 & -0.17444 \\
$\mathrm{C}$ & 0 & 0 & 0.510102 \\
$\mathrm{C}$ & 0 & -1.21489 & -0.17444 \\
$\mathrm{C}$ & 0 & -1.20581 & -1.56778 \\
$\mathrm{H}$ & 0 & -2.1547 & -2.10927 \\
$\mathrm{H}$ & 0 & -2.15168 & 0.384972 \\
$\mathrm{Cl}$ & 0 & 0 & 2.250739 \\
$\mathrm{H}$ & 0 & 2.151682 & 0.384972 \\
$\mathrm{H}$ & 0 & 2.154703 & -2.10927 \\
$\mathrm{H}$ & 0 & 0 & -3.35988 \\
\hline
\end{tabular}

4-chlorobenzonitrile (4-CN-PhCl)

\begin{tabular}{cccc}
\hline Atom & $\mathrm{x}$ & $\mathrm{y}$ & $\mathrm{z}$ \\
\hline $\mathrm{C}$ & -1.51412 & 0.000001 & 0 \\
$\mathrm{C}$ & -0.80644 & -1.21367 & 0 \\
$\mathrm{C}$ & 0.581824 & -1.21568 & 0 \\
$\mathrm{C}$ & 1.268079 & 0 & 0 \\
$\mathrm{C}$ & 0.581826 & 1.215682 & 0 \\
$\mathrm{C}$ & -0.80644 & 1.213669 & 0 \\
$\mathrm{H}$ & -1.35427 & 2.157478 & 0.000001 \\
$\mathrm{H}$ & 1.139459 & 2.152963 & 0 \\
$\mathrm{Cl}$ & 3.000746 & $-1 \mathrm{E}-06$ & $-1 \mathrm{E}-06$ \\
$\mathrm{H}$ & 1.139457 & -2.15296 & $-1 \mathrm{E}-06$ \\
$\mathrm{H}$ & -1.35427 & -2.15748 & 0 \\
$\mathrm{C}$ & -2.9424 & 0.000002 & 0.000001 \\
$\mathrm{~N}$ & -4.10814 & $-3 \mathrm{E}-06$ & 0.000001 \\
\hline
\end{tabular}

4-chloroanisole (4-OMe-PhCl)

\begin{tabular}{cccc}
\hline Atom & $\mathrm{x}$ & $\mathrm{y}$ & $\mathrm{z}$ \\
\hline $\mathrm{C}$ & -3.57467 & -0.56143 & 0.000042 \\
$\mathrm{O}$ & -2.69501 & 0.531391 & $-3.6 \mathrm{E}-05$ \\
$\mathrm{C}$ & -1.3656 & 0.281981 & $-1.7 \mathrm{E}-05$ \\
$\mathrm{C}$ & -0.52694 & 1.4062 & $-1 \mathrm{E}-06$ \\
$\mathrm{C}$ & 0.851186 & 1.258063 & 0.000007 \\
$\mathrm{C}$ & 1.409622 & -0.02303 & 0.000001 \\
$\mathrm{C}$ & 0.589489 & -1.1466 & $-1.3 \mathrm{E}-05$ \\
$\mathrm{C}$ & -0.79818 & -0.9978 & $-2.3 \mathrm{E}-05$ \\
$\mathrm{H}$ & -1.42405 & -1.89125 & -0.00004
\end{tabular}




\begin{tabular}{cccc}
$\mathrm{H}$ & 1.032382 & -2.14397 & $-1.9 \mathrm{E}-05$ \\
$\mathrm{Cl}$ & 3.141984 & -0.20654 & 0.000009 \\
$\mathrm{H}$ & 1.503121 & 2.13221 & 0.000021 \\
$\mathrm{H}$ & -0.98535 & 2.396737 & 0.000005 \\
$\mathrm{H}$ & -4.59019 & -0.15118 & 0.00008 \\
$\mathrm{H}$ & -3.44957 & -1.1934 & -0.89524 \\
$\mathrm{H}$ & -3.44947 & -1.19335 & 0.895349 \\
\hline
\end{tabular}

toluene

\begin{tabular}{cccc}
\hline Atom & $\mathrm{x}$ & $\mathrm{y}$ & $\mathrm{z}$ \\
\hline $\mathrm{C}$ & 2.413438 & 0.002855 & 0.005234 \\
$\mathrm{C}$ & 0.916866 & 0.005023 & -0.00725 \\
$\mathrm{C}$ & 0.198389 & -1.199 & -0.00558 \\
$\mathrm{C}$ & -1.19404 & -1.20587 & 0.00121 \\
$\mathrm{C}$ & -1.90185 & -0.00381 & 0.005339 \\
$\mathrm{C}$ & -1.2026 & 1.201246 & 0.001283 \\
$\mathrm{C}$ & 0.191706 & 1.202788 & -0.00555 \\
$\mathrm{H}$ & 0.732829 & 2.153776 & -0.01147 \\
$\mathrm{H}$ & -1.746 & 2.149548 & 0.001097 \\
$\mathrm{H}$ & -2.99427 & -0.00759 & 0.009003 \\
$\mathrm{H}$ & -1.73226 & -2.15717 & 0.00112 \\
$\mathrm{H}$ & 0.745133 & -2.14698 & -0.01113 \\
$\mathrm{H}$ & 2.827425 & 0.997801 & -0.20302 \\
$\mathrm{H}$ & 2.808263 & -0.31404 & 0.983031 \\
$\mathrm{H}$ & 2.82741 & -0.69476 & -0.73675 \\
\hline
\end{tabular}

methyl 2-diazopropanoate

\begin{tabular}{cccc}
\hline Atom & $\mathrm{x}$ & $\mathrm{y}$ & $\mathrm{z}$ \\
\hline $\mathrm{C}$ & -2.59808 & 0.575038 & 0.00072 \\
$\mathrm{O}$ & -1.18364 & 0.686188 & 0.000811 \\
$\mathrm{C}$ & -0.51429 & -0.48673 & -0.00052 \\
$\mathrm{O}$ & -1.04849 & -1.57285 & -0.00118 \\
$\mathrm{C}$ & 0.932237 & -0.29137 & -0.00209 \\
$\mathrm{~N}$ & 1.38311 & 0.934851 & -0.00026 \\
$\mathrm{~N}$ & 1.786403 & 2.002515 & $-6.7 \mathrm{E}-05$ \\
$\mathrm{C}$ & 1.884649 & -1.44125 & 0.001532 \\
$\mathrm{H}$ & 1.27844 & -2.35316 & -0.04537 \\
$\mathrm{H}$ & 2.563648 & -1.43565 & -0.86293 \\
$\mathrm{H}$ & 2.497634 & -1.48649 & 0.913509 \\
$\mathrm{H}$ & -2.95395 & 0.037177 & 0.889893 \\
$\mathrm{H}$ & -2.9884 & 1.596833 & 0.001692 \\
$\mathrm{H}$ & -2.95398 & 0.038871 & -0.88947 \\
$\mathrm{C}$ & -2.59808 & 0.575038 & 0.00072 \\
\hline
\end{tabular}

2-diazoacetophenone

\begin{tabular}{cccc}
\hline Atom & $\mathrm{x}$ & $\mathrm{y}$ & $\mathrm{z}$ \\
\hline $\mathrm{C}$ & -1.988827 & 1.74116 & -0.000014 \\
$\mathrm{C}$ & -1.382037 & 0.373563 & 0.000149 \\
$\mathrm{C}$ & 0.054687 & 0.126187 & 0.000212 \\
$\mathrm{C}$ & 0.599081 & -1.174118 & 0.000146
\end{tabular}




\begin{tabular}{cccc}
$\mathrm{C}$ & 1.973909 & -1.36912 & 0.000041 \\
$\mathrm{C}$ & 2.847532 & -0.27944 & -0.000102 \\
$\mathrm{C}$ & 2.321809 & 1.010836 & -0.000103 \\
$\mathrm{C}$ & 0.944981 & 1.216667 & 0.000019 \\
$\mathrm{H}$ & 0.556583 & 2.23761 & -0.000022 \\
$\mathrm{H}$ & 2.991346 & 1.874402 & -0.00024 \\
$\mathrm{H}$ & 3.927994 & -0.437026 & -0.00027 \\
$\mathrm{H}$ & 2.369707 & -2.387713 & 0.000032 \\
$\mathrm{H}$ & -0.067015 & -2.041244 & 0.000163 \\
$\mathrm{~N}$ & -2.189517 & -0.648585 & -0.000033 \\
$\mathrm{~N}$ & -2.890014 & -1.558436 & -0.000197 \\
$\mathrm{H}$ & -3.08365 & 1.692259 & -0.000969 \\
$\mathrm{H}$ & -1.683262 & 2.317975 & 0.887122 \\
$\mathrm{H}$ & -1.681792 & 2.318476 & -0.886296 \\
\hline
\end{tabular}

methyl 2-phenylacylate (Me 2-Ph-acrylate)

\begin{tabular}{cccc}
\hline Atom & $\mathrm{x}$ & $\mathrm{y}$ & $\mathrm{z}$ \\
\hline $\mathrm{C}$ & -3.97039 & -0.543287 & 0.193267 \\
$\mathrm{O}$ & -2.879496 & 0.318713 & -0.085272 \\
$\mathrm{C}$ & -1.658616 & -0.22209 & 0.097451 \\
$\mathrm{C}$ & -0.5597 & 0.746688 & -0.194232 \\
$\mathrm{C}$ & 0.835286 & 0.270327 & -0.07868 \\
$\mathrm{C}$ & 1.826048 & 1.133347 & 0.417751 \\
$\mathrm{C}$ & 3.156584 & 0.733715 & 0.492265 \\
$\mathrm{C}$ & 3.526854 & -0.543256 & 0.07218 \\
$\mathrm{C}$ & 2.553927 & -1.413038 & -0.4181 \\
$\mathrm{C}$ & 1.221373 & -1.016317 & -0.489368 \\
$\mathrm{H}$ & 0.471489 & -1.70702 & -0.874584 \\
$\mathrm{H}$ & 2.834421 & -2.415495 & -0.750225 \\
$\mathrm{H}$ & 4.570234 & -0.861486 & 0.132638 \\
$\mathrm{H}$ & 3.907013 & 1.420171 & 0.891455 \\
$\mathrm{H}$ & 1.537791 & 2.127238 & 0.771264 \\
$\mathrm{C}$ & -0.853839 & 2.016572 & -0.531237 \\
$\mathrm{H}$ & -1.885103 & 2.363951 & -0.586607 \\
$\mathrm{H}$ & -0.064818 & 2.7334 & -0.769684 \\
$\mathrm{O}$ & -1.502899 & -1.363448 & 0.464048 \\
$\mathrm{H}$ & -4.879235 & 0.035462 & 0.004474 \\
$\mathrm{H}$ & -3.947507 & -1.430432 & -0.454056 \\
$\mathrm{H}$ & -3.950292 & -0.883869 & 1.237345 \\
\hline
\end{tabular}

methyl 2-(4'-cyanophenyl)acrylate (Me 2-(4'-CN-Ph)acrylate)

\begin{tabular}{cccc}
\hline Atom & $\mathrm{x}$ & $\mathrm{y}$ & $\mathrm{z}$ \\
\hline $\mathrm{C}$ & -4.587315 & -0.845338 & 0.244396 \\
$\mathrm{O}$ & -3.588366 & 0.12208 & -0.044213 \\
$\mathrm{C}$ & -2.320603 & -0.303864 & 0.093642 \\
$\mathrm{C}$ & -1.325121 & 0.771963 & -0.196362 \\
$\mathrm{C}$ & 0.109372 & 0.429014 & -0.103625 \\
$\mathrm{C}$ & 1.020344 & 1.374686 & 0.397256 \\
$\mathrm{C}$ & 2.379773 & 1.1076 & 0.456994 \\
$\mathrm{C}$ & 2.870792 & -0.130659 & 0.011471
\end{tabular}




\begin{tabular}{cccc}
$\mathrm{C}$ & 1.96991 & -1.086227 & -0.486578 \\
$\mathrm{C}$ & 0.610872 & -0.810638 & -0.536756 \\
$\mathrm{H}$ & -0.073312 & -1.565547 & -0.921902 \\
$\mathrm{H}$ & 2.347036 & -2.049261 & -0.835173 \\
$\mathrm{H}$ & 3.072331 & 1.849761 & 0.857513 \\
$\mathrm{H}$ & 0.646784 & 2.331807 & 0.769412 \\
$\mathrm{C}$ & -1.738823 & 2.013045 & -0.513522 \\
$\mathrm{H}$ & -2.799057 & 2.260264 & -0.558972 \\
$\mathrm{H}$ & -1.024201 & 2.804471 & -0.750707 \\
$\mathrm{O}$ & -2.041381 & -1.432182 & 0.42535 \\
$\mathrm{H}$ & -5.550467 & -0.34828 & 0.098709 \\
$\mathrm{H}$ & -4.503365 & -1.710222 & -0.426977 \\
$\mathrm{H}$ & -4.500481 & -1.205513 & 1.278109 \\
$\mathrm{C}$ & 4.268684 & -0.415242 & 0.070255 \\
$\mathrm{~N}$ & 5.410772 & -0.644673 & 0.116837 \\
\hline
\end{tabular}

methyl 2-(4'-methoxyphenyl)acrylate (Me 2-(4'-OMe-Ph)acylate)

\begin{tabular}{cccc}
\hline Atom & $\mathrm{x}$ & $\mathrm{y}$ & $\mathrm{z}$ \\
\hline $\mathrm{C}$ & 4.665979 & -1.03607 & -0.154738 \\
$\mathrm{O}$ & 3.723491 & -0.021787 & 0.149631 \\
$\mathrm{C}$ & 2.438161 & -0.337039 & -0.109375 \\
$\mathrm{C}$ & 1.50245 & 0.787082 & 0.193155 \\
$\mathrm{C}$ & 0.054325 & 0.531613 & 0.068224 \\
$\mathrm{C}$ & -0.807689 & 1.550489 & -0.380136 \\
$\mathrm{C}$ & -2.177267 & 1.364581 & -0.458954 \\
$\mathrm{C}$ & -2.741564 & 0.136361 & -0.085201 \\
$\mathrm{C}$ & -1.904099 & -0.893828 & 0.357191 \\
$\mathrm{C}$ & -0.527357 & -0.693708 & 0.423383 \\
$\mathrm{H}$ & 0.10504 & -1.512284 & 0.767336 \\
$\mathrm{H}$ & -2.314675 & -1.860386 & 0.652499 \\
$\mathrm{H}$ & -2.838693 & 2.153142 & -0.822371 \\
$\mathrm{H}$ & -0.384492 & 2.506699 & -0.6994 \\
$\mathrm{C}$ & 1.996089 & 1.993569 & 0.53542 \\
$\mathrm{H}$ & 3.069361 & 2.173966 & 0.585147 \\
$\mathrm{H}$ & 1.33289 & 2.826124 & 0.780532 \\
$\mathrm{O}$ & 2.113688 & -1.416972 & -0.545962 \\
$\mathrm{H}$ & 5.648811 & -0.638521 & 0.11537 \\
$\mathrm{H}$ & 4.459559 & -1.951814 & 0.415876 \\
$\mathrm{H}$ & 4.643319 & -1.290077 & -1.223268 \\
$\mathrm{O}$ & -4.086071 & 0.034809 & -0.192629 \\
$\mathrm{C}$ & -4.686964 & -1.180648 & 0.169291 \\
$\mathrm{H}$ & -4.505159 & -1.431058 & 1.227839 \\
$\mathrm{H}$ & -5.764672 & -1.060253 & 0.016756 \\
$\mathrm{H}$ & -4.332545 & -2.018358 & -0.454205 \\
\hline & & &
\end{tabular}

1,1-diphenylethylene

\begin{tabular}{cccc}
\hline Atom & $\mathrm{x}$ & $\mathrm{y}$ & $\mathrm{z}$ \\
\hline $\mathrm{C}$ & 0 & 2.507462 & 0.000049 \\
$\mathrm{C}$ & -0.00001 & 1.159246 & 0.000026 \\
$\mathrm{C}$ & 1.271376 & 0.398932 & 0.036438
\end{tabular}




\begin{tabular}{|c|c|c|c|}
\hline $\mathrm{C}$ & 2.413753 & 0.857298 & -0.639294 \\
\hline $\mathrm{C}$ & 3.616785 & 0.159952 & -0.567876 \\
\hline $\mathrm{C}$ & 3.705226 & -1.013265 & 0.180552 \\
\hline $\mathrm{C}$ & 2.5783 & -1.48516 & 0.852998 \\
\hline $\mathrm{C}$ & 1.374149 & -0.791083 & 0.776243 \\
\hline $\mathrm{H}$ & 0.497085 & -1.165858 & 1.311017 \\
\hline $\mathrm{H}$ & 2.636971 & -2.402349 & 1.44396 \\
\hline $\mathrm{H}$ & 4.648107 & -1.562719 & 0.233221 \\
\hline $\mathrm{H}$ & 4.489742 & 0.529945 & -1.111218 \\
\hline $\mathrm{H}$ & 2.345917 & 1.763054 & -1.247676 \\
\hline $\mathrm{C}$ & -1.271384 & 0.398919 & -0.036414 \\
\hline $\mathrm{C}$ & -2.413831 & 0.857348 & 0.63916 \\
\hline $\mathrm{C}$ & -3.61685 & 0.159988 & 0.567703 \\
\hline $\mathrm{C}$ & -3.705215 & -1.013314 & -0.180604 \\
\hline $\mathrm{C}$ & -2.578222 & -1.485276 & -0.852886 \\
\hline $\mathrm{C}$ & -1.374083 & -0.79118 & -0.776095 \\
\hline $\mathrm{H}$ & -0.496969 & -1.16601 & -1.310749 \\
\hline $\mathrm{H}$ & -2.636827 & -2.402532 & -1.44375 \\
\hline $\mathrm{H}$ & -4.648087 & -1.562779 & -0.2333 \\
\hline $\mathrm{H}$ & -4.489861 & 0.530037 & 1.11092 \\
\hline $\mathrm{H}$ & -2.346065 & 1.763165 & 1.247458 \\
\hline $\mathrm{H}$ & -0.928456 & 3.078431 & -0.070182 \\
\hline $\mathrm{H}$ & 0.928473 & 3.078401 & 0.070298 \\
\hline \multicolumn{4}{|l|}{$\mathrm{Pr}_{2} \mathrm{NH}$} \\
\hline Atom & $\mathrm{x}$ & $\mathrm{y}$ & $\mathrm{z}$ \\
\hline $\mathrm{C}$ & -1.227217 & 0.101245 & 0.243949 \\
\hline $\mathrm{C}$ & -1.55156 & 1.081279 & -0.869535 \\
\hline $\mathrm{H}$ & -0.796616 & 1.874292 & -0.966813 \\
\hline $\mathrm{H}$ & -1.611466 & 0.557501 & -1.835832 \\
\hline $\mathrm{H}$ & -2.515887 & 1.575536 & -0.687472 \\
\hline $\mathrm{C}$ & -2.359568 & -0.887927 & 0.448575 \\
\hline $\mathrm{H}$ & -2.131894 & -1.599008 & 1.256734 \\
\hline $\mathrm{H}$ & -3.295562 & -0.377851 & 0.715172 \\
\hline $\mathrm{H}$ & -2.532855 & -1.472394 & -0.467011 \\
\hline $\mathrm{N}$ & -0.014998 & -0.645919 & -0.064918 \\
\hline $\mathrm{C}$ & 1.221192 & 0.107819 & -0.244397 \\
\hline $\mathrm{C}$ & 1.569345 & 1.044461 & 0.908155 \\
\hline $\mathrm{H}$ & 2.513917 & 1.576957 & 0.724054 \\
\hline $\mathrm{H}$ & 0.79539 & 1.80747 & 1.074831 \\
\hline $\mathrm{H}$ & 1.685856 & 0.482644 & 1.849355 \\
\hline $\mathrm{C}$ & 2.344794 & -0.874715 & -0.514621 \\
\hline $\mathrm{H}$ & 3.285888 & -0.35988 & -0.751648 \\
\hline $\mathrm{H}$ & 2.53446 & -1.50833 & 0.367297 \\
\hline $\mathrm{H}$ & 2.091199 & -1.538822 & -1.351279 \\
\hline $\mathrm{H}$ & 1.093038 & 0.723832 & -1.154184 \\
\hline $\mathrm{H}$ & 0.133304 & -1.344643 & 0.662596 \\
\hline $\mathrm{H}$ & -1.125697 & 0.691156 & 1.185873 \\
\hline
\end{tabular}


${ }^{\prime} \mathrm{Pr}_{2} \mathrm{NH} \cdot \mathrm{HCl}$

\begin{tabular}{cccc}
\hline Atom & $\mathrm{x}$ & $\mathrm{y}$ & $\mathrm{z}$ \\
\hline $\mathrm{C}$ & -1.438764 & 0.365997 & 0.202559 \\
$\mathrm{C}$ & -1.783258 & 1.72655 & -0.369611 \\
$\mathrm{H}$ & -0.915368 & 2.398431 & -0.327673 \\
$\mathrm{H}$ & -2.111499 & 1.646247 & -1.418338 \\
$\mathrm{H}$ & -2.603367 & 2.188827 & 0.194288 \\
$\mathrm{C}$ & -2.608652 & -0.59826 & 0.169813 \\
$\mathrm{H}$ & -3.474024 & -0.16937 & 0.69271 \\
$\mathrm{H}$ & -2.923354 & -0.808606 & -0.864615 \\
$\mathrm{H}$ & -2.381152 & -1.558183 & 0.653507 \\
$\mathrm{~N}$ & -0.250601 & -0.144139 & -0.51703 \\
$\mathrm{C}$ & 0.264741 & -1.490895 & -0.171146 \\
$\mathrm{C}$ & 1.4846 & -1.750334 & -1.034014 \\
$\mathrm{H}$ & 1.898534 & -2.746642 & -0.833074 \\
$\mathrm{H}$ & 1.242768 & -1.705176 & -2.106056 \\
$\mathrm{H}$ & 2.262101 & -1.000554 & -0.828745 \\
$\mathrm{C}$ & 0.590736 & -1.561016 & 1.308132 \\
$\mathrm{H}$ & -0.303199 & -1.488644 & 1.942733 \\
$\mathrm{H}$ & 1.076228 & -2.517579 & 1.540381 \\
$\mathrm{H}$ & 1.278302 & -0.748294 & 1.584588 \\
$\mathrm{H}$ & -0.512697 & -2.24257 & -0.410571 \\
$\mathrm{H}$ & -0.423872 & -0.10207 & -1.523306 \\
$\mathrm{H}$ & 0.734812 & 0.72218 & -0.245796 \\
$\mathrm{H}$ & -1.106634 & 0.508957 & 1.245508 \\
$\mathrm{Cl}$ & 1.821188 & 1.675281 & 0.217016 \\
\hline & & & \\
& & &
\end{tabular}

L-Pd-tol

\begin{tabular}{cccc}
\hline Atom & $\mathrm{x}$ & $\mathrm{y}$ & $\mathrm{z}$ \\
\hline $\mathrm{C}$ & 1.99474 & -1.505964 & -0.320184 \\
$\mathrm{C}$ & 2.266851 & -1.638166 & -1.819251 \\
$\mathrm{C}$ & 2.936105 & -2.963488 & -2.151631 \\
$\mathrm{C}$ & 4.199985 & -3.170845 & -1.330609 \\
$\mathrm{C}$ & 3.916004 & -3.048034 & 0.15889 \\
$\mathrm{C}$ & 3.270237 & -1.709457 & 0.500731 \\
$\mathrm{H}$ & 3.049606 & -1.664002 & 1.579034 \\
$\mathrm{H}$ & 4.003056 & -0.907781 & 0.304664 \\
$\mathrm{H}$ & 3.237589 & -3.864007 & 0.46782 \\
$\mathrm{H}$ & 4.838073 & -3.185631 & 0.745267 \\
$\mathrm{H}$ & 4.656871 & -4.146616 & -1.558453 \\
$\mathrm{H}$ & 4.949977 & -2.412265 & -1.620574 \\
$\mathrm{H}$ & 2.227729 & -3.786334 & -1.944009 \\
$\mathrm{H}$ & 3.156494 & -3.020805 & -3.229002 \\
$\mathrm{H}$ & 1.323064 & -1.526471 & -2.381172 \\
$\mathrm{H}$ & 2.914535 & -0.804645 & -2.148276
\end{tabular}




\begin{tabular}{|c|c|c|c|}
\hline I & 1.328206 & -2.348439 & 4865 \\
\hline . & 0.822494 & -0.08635 & 0.000015 \\
\hline $\mathrm{C}$ & 0.922331 & 0.193386 & 1.845614 \\
\hline $\mathrm{C}$ & 2.13448 & 0.960327 & 2.371852 \\
\hline $\mathrm{C}$ & 2.130285 & 1.013676 & 3.894907 \\
\hline $\mathrm{C}$ & 0.843503 & 1.628647 & 4.425066 \\
\hline $\mathrm{C}$ & -0.381778 & 0.910265 & 3.878545 \\
\hline $\mathrm{C}$ & -0.365109 & 0.842171 & 2.359127 \\
\hline $\mathrm{H}$ & -0.441695 & 1.863256 & 1.938757 \\
\hline $\mathrm{H}$ & -1.243433 & 0.296165 & 1.975072 \\
\hline $\mathrm{H}$ & -1.306872 & 1.394869 & 4.228838 \\
\hline $\mathrm{H}$ & -0.4117 & -0.119533 & 4.280429 \\
\hline $\mathrm{H}$ & 0.838024 & 1.627919 & 5.526476 \\
\hline $\mathrm{H}$ & 0.803873 & 2.691407 & 4.124606 \\
\hline $\mathrm{H}$ & 3.006686 & 1.573521 & 4.258316 \\
\hline $\mathrm{H}$ & 2.24066 & -0.011337 & 4.294754 \\
\hline $\mathrm{H}$ & 2.101605 & 1.991539 & 1.975038 \\
\hline $\mathrm{H}$ & 3.079301 & 0.532138 & 2.002477 \\
\hline $\mathrm{H}$ & 0.954008 & -0.841075 & 2.246883 \\
\hline $\mathrm{C}$ & 1.592723 & 1.442626 & -0.692426 \\
\hline $\mathrm{C}$ & 0.759205 & 2.499466 & -1.140452 \\
\hline $\mathrm{C}$ & 1.347921 & 3.71765 & -1.51595 \\
\hline $\mathrm{C}$ & 2.727397 & 3.895413 & -1.504389 \\
\hline $\mathrm{C}$ & 3.551525 & 2.844411 & -1.110319 \\
\hline $\mathrm{C}$ & 2.981608 & 1.642943 & -0.699449 \\
\hline $\mathrm{H}$ & 3.639283 & 0.842548 & -0.355936 \\
\hline $\mathrm{H}$ & 4.637647 & 2.962677 & -1.105779 \\
\hline $\mathrm{H}$ & 3.157374 & 4.850558 & -1.815353 \\
\hline $\mathrm{H}$ & 0.695495 & 4.529704 & -1.848977 \\
\hline $\mathrm{C}$ & -0.717981 & 2.386443 & -1.25792 \\
\hline $\mathrm{C}$ & -1.290017 & 1.466189 & -2.165292 \\
\hline $\mathrm{C}$ & -2.680294 & 1.397184 & -2.318468 \\
\hline $\mathrm{C}$ & -3.512554 & 2.228262 & -1.5629 \\
\hline $\mathrm{C}$ & -2.954829 & 3.140238 & -0.671663 \\
\hline $\mathrm{C}$ & -1.565806 & 3.22284 & -0.527356 \\
\hline $\mathrm{H}$ & -1.130556 & 3.937156 & 0.17778 \\
\hline $\mathrm{H}$ & -3.600187 & 3.797735 & -0.084522 \\
\hline $\mathrm{H}$ & -4.597233 & 2.165824 & -1.678643 \\
\hline $\mathrm{H}$ & -3.106453 & 0.708112 & -3.051923 \\
\hline $\mathrm{H}$ & -0.635161 & 0.89217 & -2.827572 \\
\hline $\mathrm{Pd}$ & -1.344029 & -0.56014 & -0.651217 \\
\hline $\mathrm{C}$ & -1.584948 & -3.554759 & -1.117814 \\
\hline $\mathrm{C}$ & -2.208137 & -2.578015 & -0.158948 \\
\hline $\mathrm{C}$ & -3.250444 & -1.68903 & -0.585726 \\
\hline $\mathrm{C}$ & -4.022727 & -0.998855 & 0.38514 \\
\hline $\mathrm{C}$ & -3.814099 & -1.198838 & 1.73912 \\
\hline $\mathrm{C}$ & -2.825427 & -2.108019 & 2.169001 \\
\hline $\mathrm{C}$ & -2.041449 & -2.771907 & 1.244467 \\
\hline $\mathrm{H}$ & -1.279595 & -3.483 & 1.582506 \\
\hline $\mathrm{H}$ & -2.671539 & -2.280691 & 3.237552 \\
\hline $\mathrm{H}$ & -4.423783 & -0.664592 & 2.471672 \\
\hline
\end{tabular}




\begin{tabular}{cccc}
$\mathrm{H}$ & -4.812596 & -0.321742 & 0.048357 \\
$\mathrm{H}$ & -3.58968 & -1.710522 & -1.627359 \\
$\mathrm{H}$ & -0.534732 & -3.762543 & -0.86386 \\
$\mathrm{H}$ & -2.113419 & -4.523317 & -1.100549 \\
$\mathrm{H}$ & -1.608401 & -3.190803 & -2.153987 \\
$\mathrm{C}$ & 2.266851 & -1.638166 & -1.819251 \\
$\mathrm{C}$ & 2.936105 & -2.963488 & -2.151631 \\
$\mathrm{C}$ & 4.199985 & -3.170845 & -1.330609 \\
$\mathrm{C}$ & 3.916004 & -3.048034 & 0.15889 \\
$\mathrm{C}$ & 3.270237 & -1.709457 & 0.500731 \\
$\mathrm{H}$ & 3.049606 & -1.664002 & 1.579034 \\
$\mathrm{H}$ & 4.003056 & -0.907781 & 0.304664 \\
$\mathrm{H}$ & 3.237589 & -3.864007 & 0.46782 \\
$\mathrm{H}$ & 4.838073 & -3.185631 & 0.745267 \\
$\mathrm{H}$ & 4.656871 & -4.146616 & -1.558453 \\
$\mathrm{H}$ & 4.949977 & -2.412265 & -1.620574 \\
$\mathrm{H}$ & 2.227729 & -3.786334 & -1.944009 \\
$\mathrm{H}$ & 3.156494 & -3.020805 & -3.229002 \\
$\mathrm{H}$ & 1.323064 & -1.526471 & -2.381172 \\
$\mathrm{H}$ & 2.914535 & -0.804645 & -2.148276 \\
$\mathrm{H}$ & 1.328206 & -2.348439 & -0.044865 \\
$\mathrm{P}$ & 0.822494 & -0.08635 & 0.000015 \\
$\mathrm{C}$ & 0.922331 & 0.193386 & 1.845614 \\
$\mathrm{C}$ & 2.13448 & 0.960327 & 2.371852 \\
$\mathrm{C}$ & 2.130285 & 1.013676 & 3.894907 \\
$\mathrm{C}$ & 0.843503 & 1.628647 & 4.425066 \\
$\mathrm{C}$ & -0.381778 & 0.910265 & 3.878545 \\
$\mathrm{C}$ & -0.365109 & 0.842171 & 2.359127 \\
$\mathrm{H}$ & -0.441695 & 1.863256 & 1.938757 \\
$\mathrm{H}$ & -1.243433 & 0.296165 & 1.975072 \\
$\mathrm{H}$ & -1.306872 & 1.394869 & 4.228838 \\
$\mathrm{H}$ & -0.4117 & -0.119533 & 4.280429 \\
$\mathrm{H}$ & 0.838024 & 1.627919 & 5.526476 \\
$\mathrm{H}$ & 0.803873 & 2.691407 & 4.124606 \\
$\mathrm{H}$ & 3.006686 & 1.573521 & 4.258316 \\
$\mathrm{H}$ & 2.24066 & -0.011337 & 4.294754 \\
$\mathrm{H}$ & 2.101605 & 1.991539 & 1.975038 \\
$\mathrm{H}$ & 3.079301 & 0.532138 & 2.002477 \\
\hline & & & \\
\hline
\end{tabular}

\begin{tabular}{|c|c|c|c|}
\hline \multicolumn{4}{|c|}{$\underset{\stackrel{\mathrm{Ph}}{\mathrm{L}-\mathrm{Pd}-\mathrm{Cl}^{ \pm}}}{\neq} \quad($ TS1a) } \\
\hline Atom & $\mathrm{x}$ & $\mathrm{y}$ & $\mathrm{z}$ \\
\hline $\mathrm{C}$ & -1.463326 & 0.36755 & 1.733339 \\
\hline $\mathrm{C}$ & -2.55849 & 1.368429 & 2.101658 \\
\hline $\mathrm{C}$ & -3.086844 & 1.102249 & 3.50709 \\
\hline $\mathrm{C}$ & -3.56614 & -0.332572 & 3.669823 \\
\hline $\mathrm{C}$ & -2.462214 & -1.32025 & 3.323178 \\
\hline $\mathrm{C}$ & -1.922608 & -1.080143 & 1.921557 \\
\hline $\mathrm{H}$ & -1.089115 & -1.76588 & 1.696185 \\
\hline
\end{tabular}




\begin{tabular}{|c|c|c|c|}
\hline $\mathrm{H}$ & -2.7125 & -1.321323 & 1.186544 \\
\hline $\mathrm{H}$ & -1.637853 & -1.214421 & 4.051664 \\
\hline $\mathrm{H}$ & -2.817842 & -2.358505 & 3.41981 \\
\hline $\mathrm{H}$ & -3.937235 & -0.504192 & 4.692445 \\
\hline $\mathrm{H}$ & -4.430322 & -0.504461 & 3.001823 \\
\hline $\mathrm{H}$ & -2.281352 & 1.29906 & 4.237841 \\
\hline $\mathrm{H}$ & -3.891652 & 1.813788 & 3.749884 \\
\hline $\mathrm{H}$ & -2.175973 & 2.398601 & 2.030325 \\
\hline $\mathrm{H}$ & -3.395185 & 1.306968 & 1.384731 \\
\hline $\mathrm{H}$ & -0.635188 & 0.530258 & 2.452151 \\
\hline $\mathrm{P}$ & -0.591338 & 0.537517 & 0.091417 \\
\hline $\mathrm{Pd}$ & 1.406254 & -0.61518 & 0.064524 \\
\hline $\mathrm{C}$ & 1.338279 & -2.826454 & -0.485043 \\
\hline $\mathrm{C}$ & 0.366962 & -3.058966 & -1.478607 \\
\hline $\mathrm{C}$ & -0.77731 & -3.770837 & -1.142644 \\
\hline $\mathrm{C}$ & -0.936835 & -4.314673 & 0.13865 \\
\hline $\mathrm{C}$ & 0.077848 & -4.154072 & 1.084473 \\
\hline $\mathrm{C}$ & 1.23522 & -3.442395 & 0.77843 \\
\hline $\mathrm{H}$ & 2.044412 & -3.333655 & 1.503035 \\
\hline $\mathrm{H}$ & -0.024776 & -4.598071 & 2.078362 \\
\hline $\mathrm{H}$ & -1.834804 & -4.884287 & 0.386226 \\
\hline $\mathrm{H}$ & -1.555376 & -3.911469 & -1.898802 \\
\hline $\mathrm{H}$ & 0.506441 & -2.643273 & -2.4787 \\
\hline $\mathrm{Cl}$ & 3.013379 & -2.317487 & -1.020674 \\
\hline C & -0.343239 & 2.352204 & -0.116535 \\
\hline $\mathrm{C}$ & 0.949738 & 2.946377 & -0.065286 \\
\hline $\mathrm{C}$ & 2.177904 & 2.203093 & 0.283607 \\
\hline $\mathrm{C}$ & 2.209538 & 1.304031 & 1.377897 \\
\hline $\mathrm{C}$ & 3.381411 & 0.589165 & 1.679102 \\
\hline $\mathrm{C}$ & 4.519972 & 0.744212 & 0.887987 \\
\hline $\mathrm{C}$ & 4.501237 & 1.633314 & -0.186469 \\
\hline $\mathrm{C}$ & 3.344201 & 2.357514 & -0.478454 \\
\hline $\mathrm{H}$ & 3.328512 & 3.028315 & -1.341808 \\
\hline $\mathrm{H}$ & 5.390203 & 1.760239 & -0.808251 \\
\hline $\mathrm{H}$ & 5.423039 & 0.172666 & 1.1141 \\
\hline $\mathrm{H}$ & 3.400106 & -0.067109 & 2.552656 \\
\hline $\mathrm{H}$ & 1.37507 & 1.295096 & 2.084621 \\
\hline $\mathrm{C}$ & 1.073922 & 4.311615 & -0.381249 \\
\hline $\mathrm{C}$ & -0.023004 & 5.092575 & -0.72173 \\
\hline $\mathrm{C}$ & -1.29262 & 4.517776 & -0.754748 \\
\hline $\mathrm{C}$ & -1.436528 & 3.167693 & -0.456495 \\
\hline $\mathrm{H}$ & -2.434836 & 2.727821 & -0.488025 \\
\hline $\mathrm{H}$ & -2.168924 & 5.118843 & -1.00831 \\
\hline $\mathrm{H}$ & 0.111622 & 6.152798 & -0.948875 \\
\hline $\mathrm{H}$ & 2.066036 & 4.768358 & -0.329334 \\
\hline $\mathrm{C}$ & -1.801869 & -0.011414 & -1.223479 \\
\hline $\mathrm{C}$ & -3.305509 & 0.267483 & -1.165421 \\
\hline $\mathrm{C}$ & -4.030577 & -0.493689 & -2.270846 \\
\hline $\mathrm{C}$ & -3.478597 & -0.14903 & -3.645137 \\
\hline $\mathrm{C}$ & -1.980058 & -0.397547 & -3.711891 \\
\hline $\mathrm{C}$ & -1.24017 & 0.33774 & -2.604004 \\
\hline
\end{tabular}




\begin{tabular}{cccc}
$\mathrm{H}$ & -1.324802 & 1.429127 & -2.762599 \\
$\mathrm{H}$ & -0.159806 & 0.114252 & -2.63861 \\
$\mathrm{H}$ & -1.579796 & -0.107505 & -4.696074 \\
$\mathrm{H}$ & -1.78873 & -1.48227 & -3.615581 \\
$\mathrm{H}$ & -4.00386 & -0.717294 & -4.428729 \\
$\mathrm{H}$ & -3.680275 & 0.916446 & -3.859132 \\
$\mathrm{H}$ & -5.112589 & -0.293438 & -2.222535 \\
$\mathrm{H}$ & -3.916145 & -1.579149 & -2.092357 \\
$\mathrm{H}$ & -3.510664 & 1.344639 & -1.289543 \\
$\mathrm{H}$ & -3.724426 & -0.015139 & -0.188225 \\
$\mathrm{H}$ & -1.688202 & -1.108902 & -1.107347 \\
\hline & & & \\
$\mathrm{L}-\mathrm{Pd}-\mathrm{Cl}$ & & & \\
$\mathrm{I}$ & $(\mathbf{I} \mathrm{a})$ & & \\
\hline $\mathrm{Atom}$ & $\mathrm{x}$ & $\mathrm{y}$ & $\mathrm{z}$ \\
\hline $\mathrm{C}$ & 1.716602 & 1.482219 & -0.17853 \\
$\mathrm{C}$ & 2.306291 & 1.409173 & -1.589273 \\
$\mathrm{C}$ & 3.779704 & 1.788026 & -1.579376 \\
$\mathrm{C}$ & 3.9995 & 3.149013 & -0.937778 \\
$\mathrm{C}$ & 3.423853 & 3.192667 & 0.469596 \\
$\mathrm{C}$ & 1.938706 & 2.843071 & 0.486407 \\
$\mathrm{H}$ & 1.573495 & 2.826673 & 1.525723 \\
$\mathrm{H}$ & 1.374567 & 3.64626 & -0.017019 \\
$\mathrm{H}$ & 3.967498 & 2.469562 & 1.104551 \\
$\mathrm{H}$ & 3.582698 & 4.180414 & 0.929695 \\
$\mathrm{H}$ & 5.070745 & 3.402199 & -0.92231 \\
$\mathrm{C}$ & -1.131519 & 1.561114 & -1.130079 \\
$\mathrm{H}$ & 3.515331 & 3.92892 & -1.554466 \\
$\mathrm{C}$ & -2.941019 & 1.072045 & -1.36667 \\
$\mathrm{H}$ & 4.339872 & 1.020829 & -1.014764 \\
$\mathrm{H}$ & 4.182706 & 1.767896 & -2.603664 \\
$\mathrm{H}$ & 2.168176 & 0.393255 & -1.994915 \\
$\mathrm{H}$ & 1.759645 & 2.080011 & -2.274287 \\
$\mathrm{H}$ & 2.305624 & 0.768698 & 0.428227 \\
$\mathrm{P}$ & 0.066403 & 0.640353 & -0.075741 \\
$\mathrm{Pd}$ & 0.209091 & -1.58215 & -0.598856 \\
$\mathrm{C}$ & 2.023752 & -1.666463 & 0.220976 \\
$\mathrm{C}$ & 2.186502 & -1.577784 & 1.606897 \\
$\mathrm{C}$ & 3.468636 & -1.586122 & 2.163755 \\
$\mathrm{C}$ & 4.591741 & -1.68563 & 1.344449 \\
$\mathrm{C}$ & 4.424593 & -1.804397 & -0.035328 \\
$\mathrm{C}$ & 3.146479 & -1.802717 & -0.59972 \\
$\mathrm{H}$ & 3.028655 & -1.917846 & -1.679842 \\
$\mathrm{H}$ & 5.297228 & -1.907693 & -0.68665 \\
$\mathrm{H}$ & 3.583612 & -1.687928 & 1.780359 \\
$\mathrm{C}$ & 0.319906 & -1.515543 & 3.248964 \\
$\mathrm{H}$ & & -1.166893
\end{tabular}




\begin{tabular}{llll}
$\mathrm{C}$ & -2.830799 & -2.657872 & -0.679231 \\
$\mathrm{C}$ & -3.971652 & -2.658672 & 0.120256 \\
$\mathrm{C}$ & -4.615735 & -1.455294 & 0.409635 \\
$\mathrm{C}$ & -4.110113 & -0.253177 & -0.079938 \\
$\mathrm{H}$ & -4.606541 & 0.690551 & 0.166237 \\
$\mathrm{H}$ & -5.515551 & -1.450399 & 1.029647 \\
$\mathrm{H}$ & -4.364512 & -3.600351 & 0.509643 \\
$\mathrm{H}$ & -2.30699 & -3.583664 & -0.929402 \\
$\mathrm{H}$ & -1.506488 & -1.474742 & -1.911794 \\
$\mathrm{C}$ & -3.342083 & 1.86794 & -2.091831 \\
$\mathrm{C}$ & -2.975137 & 3.103612 & -2.612197 \\
$\mathrm{C}$ & -1.682994 & 3.574602 & -2.402824 \\
$\mathrm{C}$ & -0.782993 & 2.811455 & -1.664834 \\
$\mathrm{H}$ & 0.214367 & 3.213598 & -1.493945 \\
$\mathrm{H}$ & -1.371472 & 4.54193 & -2.802859 \\
$\mathrm{H}$ & -3.695488 & 3.69171 & -3.185053 \\
$\mathrm{H}$ & -4.350068 & 1.481789 & -2.264874 \\
$\mathrm{C}$ & -0.47467 & 0.93041 & 1.682669 \\
$\mathrm{C}$ & -1.215211 & 2.247859 & 1.914175 \\
$\mathrm{C}$ & -1.4724 & 2.469885 & 3.398802 \\
$\mathrm{C}$ & -2.230661 & 1.302616 & 4.013543 \\
$\mathrm{C}$ & -1.520954 & -0.019357 & 3.758285 \\
$\mathrm{C}$ & -1.271471 & -0.235876 & 2.273128 \\
$\mathrm{H}$ & -2.238887 & -0.317023 & 1.750352 \\
$\mathrm{H}$ & -0.760922 & -1.195155 & 2.086949 \\
$\mathrm{H}$ & -2.101172 & -0.859013 & 4.170761 \\
$\mathrm{H}$ & -0.554268 & -0.028131 & 4.294936 \\
$\mathrm{H}$ & -2.380498 & 1.463282 & 5.092378 \\
$\mathrm{H}$ & -3.242742 & 1.257857 & 3.570986 \\
$\mathrm{H}$ & -2.018129 & 3.413876 & 3.551959 \\
$\mathrm{H}$ & -0.503962 & 2.593965 & 3.917434 \\
$\mathrm{H}$ & -2.180381 & 2.210167 & 1.37555 \\
$\mathrm{H}$ & -0.669176 & 3.099723 & 1.478532 \\
$\mathrm{H}$ & 0.495837 & 0.971661 & 2.21935 \\
\hline & & & \\
\hline & & &
\end{tabular}

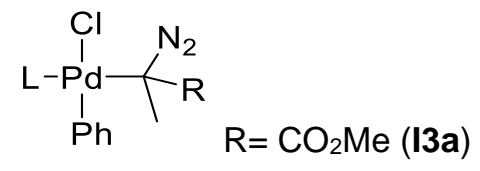

\begin{tabular}{cccc}
\hline Atom & $\mathrm{x}$ & $\mathrm{y}$ & $\mathrm{z}$ \\
\hline $\mathrm{C}$ & 0.830992 & 2.059655 & -0.379162 \\
$\mathrm{C}$ & 0.369255 & 2.994276 & 0.738494 \\
$\mathrm{C}$ & 0.240302 & 4.418255 & 0.21598 \\
$\mathrm{C}$ & 1.555234 & 4.911712 & -0.369968 \\
$\mathrm{C}$ & 2.092129 & 3.955745 & -1.424695 \\
$\mathrm{C}$ & 2.18969 & 2.529308 & -0.896776 \\
$\mathrm{H}$ & 2.59236 & 1.859754 & -1.674283 \\
$\mathrm{H}$ & 2.910986 & 2.496424 & -0.060029 \\
$\mathrm{H}$ & 1.423676 & 3.964009 & -2.305076 \\
$\mathrm{H}$ & 3.074802 & 4.29276 & -1.790806 \\
$\mathrm{H}$ & 1.44126 & 5.923571 & -0.789051
\end{tabular}




\begin{tabular}{|c|c|c|c|}
\hline $\mathrm{H}$ & 2.29882 & 5.004263 & 0.442299 \\
\hline $\mathrm{H}$ & -0.549139 & 4.445343 & -0.556663 \\
\hline $\mathrm{H}$ & -0.102152 & 5.088255 & 1.019904 \\
\hline $\mathrm{H}$ & -0.582974 & 2.650457 & 1.168216 \\
\hline $\mathrm{H}$ & 1.10848 & 2.968912 & 1.559576 \\
\hline $\mathrm{H}$ & 0.088752 & 2.13589 & -1.195794 \\
\hline $\mathrm{P}$ & 0.748041 & 0.269398 & 0.092186 \\
\hline $\mathrm{C}$ & 1.491761 & -0.632192 & -1.348943 \\
\hline $\mathrm{C}$ & 1.343955 & -2.149299 & -1.227622 \\
\hline $\mathrm{C}$ & 1.988507 & -2.866085 & -2.40339 \\
\hline $\mathrm{C}$ & 1.432783 & -2.381735 & -3.732738 \\
\hline $\mathrm{C}$ & 1.545857 & -0.870375 & -3.849174 \\
\hline $\mathrm{C}$ & 0.877095 & -0.169691 & -2.674252 \\
\hline $\mathrm{H}$ & -0.198694 & -0.418306 & -2.667121 \\
\hline $\mathrm{H}$ & 0.940064 & 0.922183 & -2.801133 \\
\hline $\mathrm{H}$ & 1.109831 & -0.514665 & -4.79586 \\
\hline $\mathrm{H}$ & 2.613204 & -0.581693 & -3.878588 \\
\hline $\mathrm{H}$ & 1.943091 & -2.875574 & -4.574427 \\
\hline $\mathrm{H}$ & 0.369132 & -2.670503 & -3.811162 \\
\hline $\mathrm{H}$ & 1.852254 & -3.953337 & -2.295737 \\
\hline $\mathrm{H}$ & 3.079526 & -2.691809 & -2.380714 \\
\hline $\mathrm{H}$ & 0.265758 & -2.392268 & -1.179844 \\
\hline $\mathrm{H}$ & 1.744473 & -2.511407 & -0.271529 \\
\hline $\mathrm{H}$ & 2.565994 & -0.375632 & -1.366412 \\
\hline $\mathrm{C}$ & 1.790471 & 0.203124 & 1.608842 \\
\hline $\mathrm{C}$ & 3.18405 & 0.001413 & 1.719766 \\
\hline $\mathrm{C}$ & 3.792138 & 0.179634 & 2.974197 \\
\hline $\mathrm{C}$ & 3.063097 & 0.53641 & 4.102031 \\
\hline $\mathrm{C}$ & 1.684578 & 0.705747 & 3.99957 \\
\hline $\mathrm{C}$ & 1.066023 & 0.532491 & 2.769124 \\
\hline $\mathrm{H}$ & -0.020249 & 0.646257 & 2.692486 \\
\hline $\mathrm{H}$ & 1.087215 & 0.960508 & 4.877298 \\
\hline $\mathrm{H}$ & 3.569129 & 0.663458 & 5.061892 \\
\hline $\mathrm{H}$ & 4.870077 & 0.013472 & 3.052002 \\
\hline $\mathrm{C}$ & 4.075389 & -0.470806 & 0.623923 \\
\hline $\mathrm{C}$ & 4.201816 & -1.846419 & 0.386144 \\
\hline $\mathrm{C}$ & 5.061806 & -2.319953 & -0.602963 \\
\hline $\mathrm{C}$ & 5.812898 & -1.427422 & -1.367064 \\
\hline $\mathrm{C}$ & 5.720676 & -0.059184 & -1.115614 \\
\hline $\mathrm{C}$ & 4.868214 & 0.413798 & -0.118709 \\
\hline $\mathrm{H}$ & 4.818272 & 1.485387 & 0.089222 \\
\hline $\mathrm{H}$ & 6.324256 & 0.645914 & -1.692335 \\
\hline $\mathrm{H}$ & 6.482794 & -1.799225 & -2.146013 \\
\hline $\mathrm{H}$ & 5.14401 & -3.395684 & -0.777391 \\
\hline $\mathrm{H}$ & 3.616477 & -2.544872 & 0.990594 \\
\hline $\mathrm{Pd}$ & -1.322546 & -0.581456 & 0.53944 \\
\hline $\mathrm{C}$ & -2.269433 & 0.991825 & -0.302747 \\
\hline $\mathrm{C}$ & -2.390202 & 1.215059 & -1.682564 \\
\hline $\mathrm{C}$ & -3.118966 & 2.299537 & -2.179851 \\
\hline $\mathrm{C}$ & -3.751258 & 3.18365 & -1.306261 \\
\hline $\mathrm{C}$ & -3.656696 & 2.966573 & 0.068079 \\
\hline
\end{tabular}




\begin{tabular}{cccc}
$\mathrm{C}$ & -2.921152 & 1.887141 & 0.560864 \\
$\mathrm{H}$ & -2.871933 & 1.738643 & 1.645902 \\
$\mathrm{H}$ & -4.160166 & 3.640571 & 0.766692 \\
$\mathrm{H}$ & -4.320043 & 4.032746 & -1.693421 \\
$\mathrm{H}$ & -3.19628 & 2.447377 & -3.261321 \\
$\mathrm{H}$ & -1.922393 & 0.530503 & -2.395712 \\
$\mathrm{C}$ & -3.430143 & -1.698589 & 0.991067 \\
$\mathrm{C}$ & -4.50228 & -0.94185 & 0.293227 \\
$\mathrm{C}$ & -3.501586 & -1.768726 & 2.495192 \\
$\mathrm{H}$ & -4.404464 & -2.300116 & 2.833789 \\
$\mathrm{H}$ & -2.604711 & -2.246862 & 2.903752 \\
$\mathrm{H}$ & -3.561247 & -0.742626 & 2.877793 \\
$\mathrm{~N}$ & -3.056591 & -2.814567 & 0.347316 \\
$\mathrm{~N}$ & -2.721753 & -3.735879 & -0.215117 \\
$\mathrm{O}$ & -5.229079 & -0.168459 & 0.864857 \\
$\mathrm{O}$ & -4.550711 & -1.214705 & -1.019416 \\
$\mathrm{C}$ & -5.512336 & -0.466278 & -1.75504 \\
$\mathrm{H}$ & -5.347017 & 0.611162 & -1.622886 \\
$\mathrm{H}$ & -5.378959 & -0.742571 & -2.804917 \\
$\mathrm{H}$ & -6.531488 & -0.711256 & -1.426669 \\
$\mathrm{Cl}$ & -0.272211 & -2.445616 & 1.734924 \\
\hline & & &
\end{tabular}

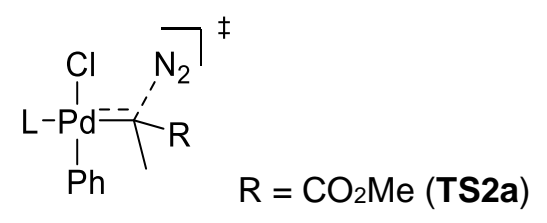

\begin{tabular}{cccc}
\hline Atom & $\mathrm{x}$ & $\mathrm{y}$ & $\mathrm{z}$ \\
\hline $\mathrm{C}$ & 0.985171 & 1.984999 & -0.67458 \\
$\mathrm{C}$ & 0.835839 & 3.163682 & 0.287443 \\
$\mathrm{C}$ & 0.833434 & 4.476841 & -0.481993 \\
$\mathrm{C}$ & 2.101212 & 4.630568 & -1.309964 \\
$\mathrm{C}$ & 2.331354 & 3.427631 & -2.213302 \\
$\mathrm{C}$ & 2.304769 & 2.119809 & -1.430012 \\
$\mathrm{H}$ & 2.488556 & 1.26684 & -2.10322 \\
$\mathrm{H}$ & 3.130405 & 2.114516 & -0.696512 \\
$\mathrm{H}$ & 1.543399 & 3.392603 & -2.987653 \\
$\mathrm{H}$ & 3.283978 & 3.527073 & -2.757331 \\
$\mathrm{H}$ & 2.06995 & 5.557434 & -1.903775 \\
$\mathrm{H}$ & 2.965123 & 4.73837 & -0.629104 \\
$\mathrm{H}$ & -0.052025 & 4.502244 & -1.142175 \\
$\mathrm{H}$ & 0.718489 & 5.324791 & 0.211292 \\
$\mathrm{H}$ & -0.077872 & 3.064133 & 0.892092 \\
$\mathrm{H}$ & 1.680556 & 3.157697 & 1.000152 \\
$\mathrm{H}$ & 0.153882 & 2.051251 & -1.401611 \\
$\mathrm{P}$ & 0.6719 & 0.352961 & 0.152941 \\
$\mathrm{C}$ & 1.124588 & -0.907973 & -1.127539 \\
$\mathrm{C}$ & 0.798134 & -2.337192 & -0.689901 \\
$\mathrm{C}$ & 1.223387 & -3.344818 & -1.747982 \\
$\mathrm{C}$ & 0.599021 & -3.045968 & -3.102303 \\
$\mathrm{C}$ & 0.848023 & -1.606515 & -3.522085
\end{tabular}




\begin{tabular}{|c|c|c|c|}
\hline $\mathrm{C}$ & 0.399294 & -0.624845 & -2.448062 \\
\hline $\mathrm{H}$ & -0.689135 & -0.731788 & -2.277665 \\
\hline$x$ & 0.553382 & 0.409005 & -2.794414 \\
\hline $\mathrm{H}$ & 0.340015 & -1.384354 & -4.473617 \\
\hline $\mathrm{H}$ & 1.927466 & -1.457957 & -3.71219 \\
\hline $\mathrm{H}$ & 0.972683 & -3.744654 & -3.867209 \\
\hline $\mathrm{H}$ & -0.490873 & -3.215906 & -3.047135 \\
\hline $\mathrm{H}$ & 0.967514 & -4.364839 & -1.418833 \\
\hline $\mathrm{H}$ & 2.324009 & -3.32554 & -1.843445 \\
\hline $\mathrm{H}$ & -0.292165 & -2.408536 & -0.514853 \\
\hline $\mathrm{H}$ & 1.249213 & -2.571192 & 0.284214 \\
\hline $\mathrm{H}$ & 2.211254 & -0.825838 & -1.309657 \\
\hline $\mathrm{C}$ & 1.845013 & 0.390554 & 1.571006 \\
\hline $\mathrm{C}$ & 3.209457 & 0.024902 & 1.612898 \\
\hline $\mathrm{C}$ & 3.958178 & 0.349364 & 2.756439 \\
\hline $\mathrm{C}$ & 3.392819 & 1.002673 & 3.84551 \\
\hline $\mathrm{C}$ & 2.038886 & 1.32756 & 3.821546 \\
\hline $\mathrm{C}$ & 1.283108 & 1.016012 & 2.698967 \\
\hline $\mathrm{H}$ & 0.215055 & 1.254859 & 2.685462 \\
\hline $\mathrm{H}$ & 1.566758 & 1.813727 & 4.677815 \\
\hline $\mathrm{H}$ & 4.005434 & 1.238725 & 4.718709 \\
\hline $\mathrm{H}$ & 5.011869 & 0.05822 & 2.782747 \\
\hline $\mathrm{C}$ & 3.917347 & -0.76762 & 0.56847 \\
\hline $\mathrm{C}$ & 3.832573 & -2.166692 & 0.597162 \\
\hline C & 4.517955 & -2.941395 & -0.336378 \\
\hline $\mathrm{C}$ & 5.303745 & -2.330921 & -1.313241 \\
\hline $\mathrm{C}$ & 5.424993 & -0.942085 & -1.329034 \\
\hline $\mathrm{C}$ & 4.748589 & -0.168364 & -0.386917 \\
\hline $\mathrm{H}$ & 4.868976 & 0.917566 & -0.389913 \\
\hline $\mathrm{H}$ & 6.060423 & -0.456027 & -2.073406 \\
\hline $\mathrm{H}$ & 5.836174 & -2.937572 & -2.049577 \\
\hline $\mathrm{H}$ & 4.436801 & -4.030604 & -0.299234 \\
\hline $\mathrm{H}$ & 3.223233 & -2.645608 & 1.368577 \\
\hline $\mathrm{Pd}$ & -1.59317 & -0.117004 & 0.747732 \\
\hline $\mathrm{C}$ & -2.246966 & 1.502495 & -0.30483 \\
\hline $\mathrm{C}$ & -2.485131 & 1.55371 & -1.683216 \\
\hline $\mathrm{C}$ & -2.977142 & 2.717616 & -2.282547 \\
\hline $\mathrm{C}$ & -3.248623 & 3.848853 & -1.51444 \\
\hline $\mathrm{C}$ & -3.029033 & 3.806539 & -0.137816 \\
\hline $\mathrm{C}$ & -2.536765 & 2.643712 & 0.458953 \\
\hline $\mathrm{H}$ & -2.383931 & 2.631216 & 1.544577 \\
\hline $\mathrm{H}$ & -3.245977 & 4.682721 & 0.480197 \\
\hline $\mathrm{H}$ & -3.638168 & 4.755592 & -1.983976 \\
\hline $\mathrm{H}$ & -3.160688 & 2.730933 & -3.360713 \\
\hline $\mathrm{H}$ & -2.321505 & 0.672514 & -2.309095 \\
\hline $\mathrm{C}$ & -3.555434 & -0.71353 & 0.650124 \\
\hline $\mathrm{C}$ & -3.614711 & -1.615209 & -0.536146 \\
\hline $\mathrm{O}$ & -4.029809 & -1.226833 & -1.606196 \\
\hline $\mathrm{O}$ & -3.08213 & -2.830435 & -0.331751 \\
\hline $\mathrm{C}$ & -3.032241 & -3.681255 & -1.466518 \\
\hline $\mathrm{H}$ & -2.373881 & -4.514562 & -1.201245 \\
\hline
\end{tabular}




\begin{tabular}{cccc}
$\mathrm{H}$ & -4.033162 & -4.061159 & -1.715405 \\
$\mathrm{H}$ & -2.640946 & -3.146267 & -2.341945 \\
$\mathrm{C}$ & -4.748806 & 0.154899 & 0.83968 \\
$\mathrm{H}$ & -5.697435 & -0.400491 & 0.860772 \\
$\mathrm{H}$ & -4.667073 & 0.791477 & 1.729271 \\
$\mathrm{H}$ & -4.786927 & 0.818922 & -0.036298 \\
$\mathrm{Cl}$ & -0.714668 & -1.691729 & 2.359202 \\
$\mathrm{~N}$ & -3.788291 & -1.960615 & 2.046796 \\
$\mathrm{~N}$ & -3.253546 & -2.558305 & 2.824108 \\
\hline
\end{tabular}<smiles>[R]C(=O)OCCCCCCCC([R])C</smiles>

\begin{tabular}{cccc}
\hline Atom & $\mathrm{x}$ & $\mathrm{y}$ & $\mathrm{z}$ \\
\hline $\mathrm{C}$ & 0.91989 & 1.875517 & -0.977532 \\
$\mathrm{C}$ & 0.31835 & 3.113019 & -0.312389 \\
$\mathrm{C}$ & 0.435115 & 4.326006 & -1.225012 \\
$\mathrm{C}$ & 1.879135 & 4.578865 & -1.633233 \\
$\mathrm{C}$ & 2.49517 & 3.345821 & -2.27724 \\
$\mathrm{C}$ & 2.371307 & 2.124572 & -1.374875 \\
$\mathrm{H}$ & 2.807055 & 1.2361 & -1.862481 \\
$\mathrm{H}$ & 2.962702 & 2.28855 & -0.45466 \\
$\mathrm{H}$ & 1.984735 & 3.138873 & -3.235826 \\
$\mathrm{H}$ & 3.551536 & 3.525078 & -2.532123 \\
$\mathrm{H}$ & 1.945814 & 5.44382 & -2.311308 \\
$\mathrm{H}$ & 2.466653 & 4.850975 & -0.737864 \\
$\mathrm{H}$ & -0.175179 & 4.155012 & -2.130739 \\
$\mathrm{H}$ & 0.006182 & 5.214138 & -0.734784 \\
$\mathrm{H}$ & -0.733685 & 2.923421 & -0.034573 \\
$\mathrm{H}$ & 0.852796 & 3.319245 & 0.63287 \\
$\mathrm{H}$ & 0.325026 & 1.686443 & -1.891413 \\
$\mathrm{P}$ & 0.636011 & 0.341365 & 0.024063 \\
$\mathrm{C}$ & 1.23844 & -1.062926 & -1.030562 \\
$\mathrm{C}$ & 0.760883 & -2.389756 & -0.428539 \\
$\mathrm{C}$ & 1.189482 & -3.579949 & -1.270605 \\
$\mathrm{C}$ & 0.707139 & -3.441985 & -2.705207 \\
$\mathrm{C}$ & 1.171985 & -2.127301 & -3.310345 \\
$\mathrm{C}$ & 0.738317 & -0.931383 & -2.472101 \\
$\mathrm{H}$ & -0.366271 & -0.85907 & -2.468866 \\
$\mathrm{H}$ & 1.107844 & -0.004173 & -2.938627 \\
$\mathrm{H}$ & 0.80266 & -2.016765 & -4.342019 \\
$\mathrm{H}$ & 2.275324 & -2.129003 & -3.381448 \\
$\mathrm{H}$ & 1.046135 & -4.291541 & -3.318397 \\
$\mathrm{H}$ & -0.39762 & -3.476036 & -2.723532 \\
$\mathrm{H}$ & 0.814609 & -4.51214 & -0.819387 \\
$\mathrm{H}$ & 2.291846 & -3.658482 & -1.262386 \\
$\mathrm{H}$ & -0.343612 & -2.363428 & -0.359525
\end{tabular}




\begin{tabular}{|c|c|c|c|}
\hline & 1.100467 & -2.492847 & 368 \\
\hline & 2.340768 & -1.052973 & -1.06168 \\
\hline & 1.680484 & 0.625065 & 1.51133 \\
\hline & 3.026437 & 0.262755 & 1.744332 \\
\hline & 3.662316 & 0.732985 & 2.904203 \\
\hline & 3.001959 & 1.53286 & 3.829862 \\
\hline $\mathrm{C}$ & 1.666068 & 1.863311 & 3.619811 \\
\hline $\mathrm{C}$ & 1.019676 & 1.404096 & 2.479119 \\
\hline $\mathrm{H}$ & -0.038317 & 1.639987 & 2.328531 \\
\hline H & 1.118895 & 2.463602 & 4.349591 \\
\hline & 3.5261 & 1.878758 & 4.723825 \\
\hline $\mathrm{H}$ & 4.702241 & 0.442727 & 3.07755 \\
\hline $\mathrm{C}$ & 3.813917 & -0.654266 & 0.87544 \\
\hline $\mathrm{C}$ & 3.724272 & -2.038127 & 1.078932 \\
\hline $\mathrm{C}$ & 4.45286 & -2.921713 & 0.285496 \\
\hline $\mathrm{C}$ & 5.288582 & -2.435936 & -0.719997 \\
\hline $\mathrm{C}$ & 5.414532 & -1.059543 & -0.905677 \\
\hline $\mathrm{C}$ & 4.69 & $-0.1^{\prime}$ & -0.1 \\
\hline $\mathrm{H}$ & 4.802006 & 2791 & -0.2 \\
\hline $\mathrm{H}$ & 6.087425 & -0.669831 & 3541 \\
\hline $\mathrm{H}$ & 5.85562 & -3.128721 & -1.346224 \\
\hline $\mathrm{H}$ & 4.366167 & -3.998103 & 0.453642 \\
\hline $\mathrm{H}$ & 3.0685 & -2.417857 & 1.867393 \\
\hline $\mathrm{Pd}$ & -1.623886 & -0.019595 & 0.521131 \\
\hline $\mathrm{Cl}$ & -1.114113 & -1.2 & 2.501533 \\
\hline $\mathrm{C}$ & -3.554891 & 0.703892 & -0.277473 \\
\hline $\mathrm{C}$ & -2.720865 & 0.46454 & -1.427797 \\
\hline $\mathrm{C}$ & -2.38432 & 1.530877 & -2.297458 \\
\hline $\mathrm{C}$ & -2.824733 & 2.813099 & -2.055036 \\
\hline $\mathrm{C}$ & -3.623454 & 3.068165 & -0.918571 \\
\hline $\mathrm{C}$ & -3.963911 & 2.058099 & -0.048681 \\
\hline $\mathrm{H}$ & -4.59353 & 2.280581 & 1059 \\
\hline $\mathrm{H}$ & -3.983771 & 4.082499 & -0.729563 \\
\hline $\mathrm{H}$ & -2.578127 & 3.625681 & -2.742203 \\
\hline $\mathrm{H}$ & -1.792374 & 1.310222 & -3.190796 \\
\hline $\mathrm{H}$ & -2.566353 & -0.557421 & -1.773568 \\
\hline $\mathrm{C}$ & -3.767527 & -0.330046 & 0.719491 \\
\hline $\mathrm{C}$ & -3.952522 & -1.776361 & 0.419762 \\
\hline $\mathrm{C}$ & -4.364785 & 0.040794 & 2.04504 \\
\hline $\mathrm{H}$ & -4.131778 & -0.734236 & 2.783183 \\
\hline $\mathrm{H}$ & -3.969067 & 0.990972 & 2.423405 \\
\hline $\mathrm{H}$ & -5.46369 & 0.116529 & 1.991715 \\
\hline $\mathrm{C}$ & -3.414512 & -3.618895 & -0.91903 \\
\hline $\mathrm{H}$ & -2.950237 & -4.172964 & -0.090968 \\
\hline $\mathrm{H}$ & -4.460573 & -3.941994 & -1.003762 \\
\hline $\mathrm{H}$ & -2.881518 & -3.822569 & -1.853645 \\
\hline $\mathrm{O}$ & -3.321836 & -2.220518 & -0.700287 \\
\hline $\mathrm{O}$ & -4.585799 & -2.522667 & 1.12761 \\
\hline
\end{tabular}




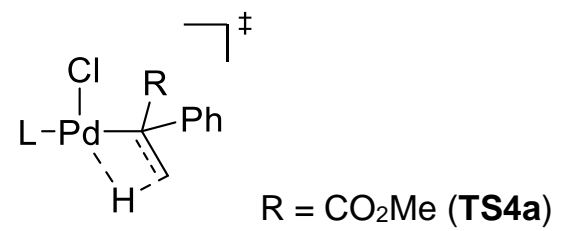

\begin{tabular}{|c|c|c|c|}
\hline Atom & $\mathrm{x}$ & $\mathrm{y}$ & $\mathrm{Z}$ \\
\hline $\mathrm{C}$ & 3.583163 & 2.123564 & -0.119957 \\
\hline $\mathrm{C}$ & 3.540587 & 0.738584 & -0.679317 \\
\hline $\mathrm{C}$ & 4.325645 & -0.363906 & -0.068659 \\
\hline $\mathrm{C}$ & 5.326119 & -0.162092 & 0.897605 \\
\hline $\mathrm{C}$ & 6.020447 & -1.242342 & 1.438598 \\
\hline $\mathrm{C}$ & 5.735811 & -2.547419 & 1.046369 \\
\hline $\mathrm{C}$ & 4.738152 & -2.766599 & 0.095914 \\
\hline $\mathrm{C}$ & 4.046968 & -1.693133 & -0.451357 \\
\hline $\mathrm{H}$ & 3.248291 & -1.894135 & -1.171691 \\
\hline $\mathrm{H}$ & 4.489047 & -3.783821 & -0.216387 \\
\hline $\mathrm{H}$ & 6.279641 & -3.389013 & 1.481769 \\
\hline $\mathrm{H}$ & 6.7947 & -1.054751 & 2.186553 \\
\hline $\mathrm{H}$ & 5.553824 & 0.8495 & 1.225097 \\
\hline $\mathrm{C}$ & 2.950619 & 0.566325 & -1.961626 \\
\hline $\mathrm{H}$ & 2.669796 & 1.458555 & -2.52389 \\
\hline $\mathrm{H}$ & 3.286178 & -0.270259 & -2.580048 \\
\hline $\mathrm{H}$ & 1.364875 & -0.114285 & -2.005656 \\
\hline $\mathrm{C}$ & -1.371964 & -1.539797 & -1.654369 \\
\hline $\mathrm{C}$ & -0.559075 & -2.833809 & -1.625134 \\
\hline $\mathrm{C}$ & -0.927796 & -3.736832 & -2.794293 \\
\hline $\mathrm{C}$ & -2.420033 & -4.032618 & -2.820759 \\
\hline $\mathrm{C}$ & -3.238867 & -2.750878 & -2.828924 \\
\hline $\mathrm{C}$ & -2.866621 & -1.846213 & -1.661592 \\
\hline $\mathrm{H}$ & -3.461408 & -0.917611 & -1.683519 \\
\hline $\mathrm{H}$ & -3.123567 & -2.351634 & -0.711952 \\
\hline $\mathrm{H}$ & -3.064026 & -2.208072 & -3.775811 \\
\hline $\mathrm{H}$ & -4.316672 & -2.975602 & -2.806884 \\
\hline $\mathrm{H}$ & -2.676166 & -4.661796 & -3.687062 \\
\hline $\mathrm{H}$ & -2.686807 & -4.625948 & -1.927678 \\
\hline $\mathrm{H}$ & -0.634294 & -3.245912 & -3.740047 \\
\hline $\mathrm{H}$ & -0.347297 & -4.671116 & -2.748459 \\
\hline $\mathrm{H}$ & 0.520825 & -2.606957 & -1.626529 \\
\hline $\mathrm{H}$ & -0.756378 & -3.368154 & -0.677959 \\
\hline $\mathrm{H}$ & -1.109331 & -1.011527 & -2.59075 \\
\hline $\mathrm{P}$ & -0.844364 & -0.34272 & -0.339402 \\
\hline $\mathrm{C}$ & -1.80773 & 1.20907 & -0.662106 \\
\hline $\mathrm{C}$ & -1.237698 & 2.352489 & 0.184025 \\
\hline $\mathrm{C}$ & -1.958128 & 3.664665 & -0.075288 \\
\hline $\mathrm{C}$ & -1.918035 & 4.029241 & -1.550336 \\
\hline $\mathrm{C}$ & -2.479323 & 2.901717 & -2.401076 \\
\hline $\mathrm{C}$ & -1.761967 & 1.58193 & -2.147508 \\
\hline $\mathrm{H}$ & -0.704706 & 1.659621 & -2.468455 \\
\hline $\mathrm{H}$ & -2.21761 & 0.795405 & -2.769495 \\
\hline $\mathrm{H}$ & -2.428834 & 3.153981 & -3.471858 \\
\hline
\end{tabular}




\begin{tabular}{cccc}
$\mathrm{H}$ & -3.55307 & 2.772117 & -2.171035 \\
$\mathrm{H}$ & -2.464971 & 4.965876 & -1.740772 \\
$\mathrm{H}$ & -0.871292 & 4.22086 & -1.84985 \\
$\mathrm{H}$ & -1.509958 & 4.462517 & 0.537964 \\
$\mathrm{H}$ & -3.010376 & 3.582184 & 0.253372 \\
$\mathrm{H}$ & -0.166182 & 2.46449 & -0.064801 \\
$\mathrm{H}$ & -1.244147 & 2.092821 & 1.252749 \\
$\mathrm{H}$ & -2.864229 & 1.042317 & -0.388911 \\
$\mathrm{C}$ & -1.313871 & -1.201741 & 1.214775 \\
$\mathrm{C}$ & -2.538464 & -1.149629 & 1.917672 \\
$\mathrm{C}$ & -2.741935 & -2.041587 & 2.982508 \\
$\mathrm{C}$ & -1.768737 & -2.955878 & 3.369485 \\
$\mathrm{C}$ & -0.546598 & -2.980666 & 2.702965 \\
$\mathrm{C}$ & -0.326706 & -2.107209 & 1.645688 \\
$\mathrm{H}$ & 0.643487 & -2.11009 & 1.138312 \\
$\mathrm{H}$ & 0.244272 & -3.666431 & 3.013182 \\
$\mathrm{H}$ & -1.958318 & -3.632584 & 4.205842 \\
$\mathrm{H}$ & -3.690144 & -1.991361 & 3.524704 \\
$\mathrm{C}$ & -3.613988 & -0.151449 & 1.665383 \\
$\mathrm{C}$ & -3.530623 & 1.110056 & 2.270972 \\
$\mathrm{C}$ & -4.528188 & 2.062192 & 2.071302 \\
$\mathrm{C}$ & -5.629282 & 1.76615 & 1.267959 \\
$\mathrm{C}$ & -5.740677 & 0.501576 & 0.690837 \\
$\mathrm{C}$ & -4.746196 & -0.453921 & 0.897469 \\
$\mathrm{H}$ & -4.846964 & -1.448486 & 0.455867 \\
$\mathrm{H}$ & -6.612967 & 0.252578 & 0.081493 \\
$\mathrm{H}$ & -6.409161 & 2.51419 & 1.107184 \\
$\mathrm{H}$ & -4.444097 & 3.042299 & 2.547551 \\
$\mathrm{H}$ & -2.669984 & 1.338399 & 2.905574 \\
$\mathrm{Pd}$ & 1.402214 & 0.197007 & -0.447981 \\
$\mathrm{Cl}$ & 1.444501 & 0.747276 & 1.904005 \\
$\mathrm{O}$ & 4.34182 & 2.543206 & 0.71782 \\
$\mathrm{O}$ & 2.634451 & 2.911196 & -0.690317 \\
$\mathrm{C}$ & 2.501035 & 4.197534 & -0.109514 \\
$\mathrm{H}$ & 1.742831 & 4.726763 & -0.696175 \\
$\mathrm{H}$ & 2.175393 & 4.111515 & 0.937008 \\
$\mathrm{H}$ & 3.450453 & 4.748892 & -0.134758 \\
\hline & & &
\end{tabular}<smiles>[R]OC(C)=O</smiles>

\begin{tabular}{cccc}
\hline Atom & $\mathrm{x}$ & $\mathrm{y}$ & $\mathrm{z}$ \\
\hline $\mathrm{C}$ & -3.6052 & -0.806651 & -0.671794 \\
$\mathrm{C}$ & -4.016269 & 0.472285 & -0.041069 \\
$\mathrm{C}$ & -3.995318 & 0.628659 & 1.35751 \\
$\mathrm{C}$ & -4.297736 & 1.857649 & 1.93468 \\
$\mathrm{C}$ & -4.629064 & 2.955899 & 1.141131 \\
$\mathrm{C}$ & -4.663497 & 2.812073 & -0.245556 \\
$\mathrm{C}$ & -4.363329 & 1.584303 & -0.827625
\end{tabular}




\begin{tabular}{|c|c|c|c|}
\hline $\mathrm{H}$ & -4.412644 & 1.487973 & -1.914903 \\
\hline $\mathrm{H}$ & -4.935547 & 3.659306 & -0.879659 \\
\hline $\mathrm{H}$ & -4.866109 & 3.918727 & 1.600701 \\
\hline $\mathrm{H}$ & -4.266656 & 1.957959 & 3.022549 \\
\hline$\Pi$ & -3.698372 & -0.210248 & 1.98523 \\
\hline $\mathrm{C}$ & -3.179088 & -0.876842 & -1.990179 \\
\hline $\mathrm{H}$ & -3.260096 & -0.020773 & -2.6591 \\
\hline $\mathrm{H}$ & -3.038701 & -1.848564 & -2.464996 \\
\hline $\mathrm{C}$ & -3.872819 & -2.083025 & 0.070477 \\
\hline $\mathrm{H}$ & -1.032642 & 0.054104 & -2.175447 \\
\hline $\mathrm{C}$ & -3.319917 & -4.337803 & 0.254689 \\
\hline $\mathrm{H}$ & -4.363761 & -4.666068 & 0.350345 \\
\hline $\mathrm{H}$ & -2.739916 & -5.081286 & -0.300291 \\
\hline $\mathrm{H}$ & -2.896283 & -4.19983 & 1.258672 \\
\hline $\mathrm{O}$ & -4.625849 & -2.184246 & 1.00635 \\
\hline $\mathrm{O}$ & -3.226139 & -3.127017 & -0.478637 \\
\hline $\mathrm{C}$ & 1.242098 & 1.656931 & -1.60301 \\
\hline $\mathrm{C}$ & 0.230246 & 2.800461 & -1.540872 \\
\hline $\mathrm{C}$ & 0.542663 & 3.852075 & -2.596409 \\
\hline $\mathrm{C}$ & 1.961401 & 4.38194 & -2.449675 \\
\hline $\mathrm{C}$ & 2.981237 & 3.253226 & -2.467852 \\
\hline $\mathrm{C}$ & 2.66075 & 2.1912 & -1.423072 \\
\hline $\mathrm{H}$ & 3.40368 & 1.376178 & -1.461366 \\
\hline $\mathrm{H}$ & 2.742842 & 2.633112 & -0.412794 \\
\hline $\mathrm{H}$ & 2.989516 & 2.781553 & -3.467527 \\
\hline $\mathrm{H}$ & 3.998923 & 3.643984 & -2.312064 \\
\hline $\mathrm{H}$ & 2.18549 & 5.117745 & -3.237434 \\
\hline $\mathrm{H}$ & 2.045331 & 4.929223 & -1.493499 \\
\hline $\mathrm{H}$ & 0.417612 & 3.407727 & -3.600361 \\
\hline $\mathrm{H}$ & -0.186886 & 4.674313 & -2.53774 \\
\hline $\mathrm{H}$ & -0.7947 & 2.409622 & -1.65862 \\
\hline $\mathrm{H}$ & 0.268041 & 3.269951 & -0.541592 \\
\hline $\mathrm{H}$ & 1.153365 & 1.203376 & -2.608153 \\
\hline $\mathrm{P}$ & 0.817712 & 0.250748 & -0.471319 \\
\hline $\mathrm{C}$ & 2.06901 & -1.065437 & -0.821509 \\
\hline $\mathrm{C}$ & 1.643766 & -2.385906 & -0.174519 \\
\hline $\mathrm{C}$ & 2.638591 & -3.497727 & -0.462695 \\
\hline $\mathrm{C}$ & 2.84878 & -3.681961 & -1.956586 \\
\hline $\mathrm{C}$ & 3.26345 & -2.373517 & -2.609034 \\
\hline $\mathrm{C}$ & 2.268281 & -1.254273 & -2.329358 \\
\hline $\mathrm{H}$ & 1.295777 & -1.489635 & -2.801611 \\
\hline $\mathrm{H}$ & 2.624169 & -0.325408 & -2.801455 \\
\hline $\mathrm{H}$ & 3.387857 & -2.4975 & -3.696107 \\
\hline $\mathrm{H}$ & 4.25493 & -2.071712 & -2.222872 \\
\hline $\mathrm{H}$ & 3.596807 & -4.465467 & -2.15432 \\
\hline $\mathrm{H}$ & 1.908763 & -4.0365 & -2.41676 \\
\hline $\mathrm{H}$ & 2.295448 & -4.434431 & 0.00328 \\
\hline $\mathrm{H}$ & 3.605506 & -3.255764 & 0.015129 \\
\hline $\mathrm{H}$ & 0.646594 & -2.659964 & -0.567411 \\
\hline $\mathrm{H}$ & 1.483495 & -2.259428 & 0.905451 \\
\hline $\mathrm{H}$ & 3.03283 & -0.739531 & -0.394489 \\
\hline
\end{tabular}




\begin{tabular}{cccc}
$\mathrm{C}$ & 0.956424 & 1.001621 & 1.202161 \\
$\mathrm{C}$ & 2.049769 & 0.981738 & 2.09388 \\
$\mathrm{C}$ & 1.951387 & 1.700847 & 3.296563 \\
$\mathrm{C}$ & 0.815298 & 2.430569 & 3.625228 \\
$\mathrm{C}$ & -0.267481 & 2.444852 & 2.749346 \\
$\mathrm{C}$ & -0.193594 & 1.73038 & 1.561837 \\
$\mathrm{H}$ & -1.06313 & 1.718593 & 0.895155 \\
$\mathrm{H}$ & -1.179312 & 2.994546 & 2.992566 \\
$\mathrm{H}$ & 0.772665 & 2.977137 & 4.570249 \\
$\mathrm{H}$ & 2.798934 & 1.670302 & 3.986705 \\
$\mathrm{C}$ & 3.306369 & 0.213413 & 1.879712 \\
$\mathrm{C}$ & 3.407392 & -1.105702 & 2.341862 \\
$\mathrm{C}$ & 4.58297 & -1.83189 & 2.160814 \\
$\mathrm{C}$ & 5.67776 & -1.249285 & 1.522674 \\
$\mathrm{C}$ & 5.599868 & 0.074464 & 1.091354 \\
$\mathrm{C}$ & 4.42638 & 0.802977 & 1.278363 \\
$\mathrm{H}$ & 4.374318 & 1.845238 & 0.95413 \\
$\mathrm{H}$ & 6.461181 & 0.546759 & 0.612492 \\
$\mathrm{H}$ & 6.597052 & -1.821357 & 1.376514 \\
$\mathrm{H}$ & 4.643041 & -2.8622 & 2.520438 \\
$\mathrm{H}$ & 2.547782 & -1.560454 & 2.8424 \\
$\mathrm{Pd}$ & -1.323872 & -0.518542 & -0.747433 \\
$\mathrm{Cl}$ & -1.274844 & -1.462046 & 1.529987 \\
\hline
\end{tabular}

\begin{tabular}{|c|c|c|c|}
\hline \multicolumn{4}{|c|}{$\mathrm{L}-\mathrm{Pd}-\mathrm{Cl}$} \\
\hline $\mathrm{H}$ & (I7) & & \\
\hline Atom & $\mathrm{x}$ & $\mathrm{y}$ & $\mathrm{z}$ \\
\hline $\mathrm{C}$ & 1.346742 & 1.014822 & -1.391293 \\
\hline $\mathrm{C}$ & 0.273244 & 2.004663 & -1.850743 \\
\hline $\mathrm{C}$ & 0.730012 & 2.784707 & -3.074933 \\
\hline $\mathrm{C}$ & 2.062355 & 3.478131 & -2.83542 \\
\hline $\mathrm{C}$ & 3.124328 & 2.491825 & -2.373279 \\
\hline $\mathrm{C}$ & 2.671855 & 1.726143 & -1.135615 \\
\hline $\mathrm{H}$ & 3.452358 & 1.012196 & -0.823135 \\
\hline $\mathrm{H}$ & 2.54846 & 2.437958 & -0.299782 \\
\hline $\mathrm{H}$ & 3.337015 & 1.773437 & -3.185448 \\
\hline $\mathrm{H}$ & 4.0756 & 3.008578 & -2.171832 \\
\hline $\mathrm{H}$ & 2.393939 & 4.005458 & -3.743182 \\
\hline $\mathrm{H}$ & 1.933564 & 4.258841 & -2.063726 \\
\hline $\mathrm{H}$ & 0.826401 & 2.089069 & -3.927614 \\
\hline $\mathrm{H}$ & -0.041768 & 3.512671 & -3.368448 \\
\hline $\mathrm{H}$ & -0.670923 & 1.470761 & -2.053255 \\
\hline $\mathrm{H}$ & 0.055453 & 2.707115 & -1.022959 \\
\hline $\mathrm{H}$ & 1.492201 & 0.281088 & -2.207863 \\
\hline $\mathrm{P}$ & 0.690544 & -0.043007 & -0.014934 \\
\hline $\mathrm{C}$ & 2.09261 & -1.124658 & 0.52142 \\
\hline $\mathrm{C}$ & 1.652008 & -1.986593 & 1.706575 \\
\hline $\mathrm{C}$ & 2.770998 & -2.904029 & 2.176482 \\
\hline $\mathrm{C}$ & 3.299708 & -3.762378 & 1.037397 \\
\hline $\mathrm{C}$ & 3.743292 & -2.906146 & -0.138386 \\
\hline
\end{tabular}




\begin{tabular}{cccc}
$\mathrm{C}$ & 2.623267 & -1.993141 & -0.619708 \\
$\mathrm{H}$ & 1.793656 & -2.603505 & -1.020766 \\
$\mathrm{H}$ & 2.973574 & -1.367343 & -1.457191 \\
$\mathrm{H}$ & 4.094938 & -3.536941 & -0.969117 \\
$\mathrm{H}$ & 4.61146 & -2.291363 & 0.162453 \\
$\mathrm{H}$ & 4.126722 & -4.401032 & 1.384144 \\
$\mathrm{H}$ & 2.504249 & -4.452137 & 0.703572 \\
$\mathrm{H}$ & 2.419527 & -3.532919 & 3.00888 \\
$\mathrm{H}$ & 3.594885 & -2.292205 & 2.587569 \\
$\mathrm{H}$ & 0.77922 & -2.591179 & 1.39407 \\
$\mathrm{H}$ & 1.300236 & -1.349061 & 2.535225 \\
$\mathrm{H}$ & 2.918106 & -0.467969 & 0.855207 \\
$\mathrm{C}$ & 0.485849 & 1.143743 & 1.379467 \\
$\mathrm{C}$ & -0.792991 & 1.64034 & 1.72002 \\
$\mathrm{C}$ & -0.890628 & 2.689025 & 2.64785 \\
$\mathrm{C}$ & 0.237148 & 3.213708 & 3.269023 \\
$\mathrm{C}$ & 1.494234 & 2.690848 & 2.973382 \\
$\mathrm{C}$ & 1.611198 & 1.672703 & 2.031706 \\
$\mathrm{H}$ & 2.607295 & 1.292654 & 1.791801 \\
$\mathrm{H}$ & 2.38709 & 3.082177 & 3.466161 \\
$\mathrm{H}$ & 0.132231 & 4.020499 & 3.997965 \\
$\mathrm{H}$ & -1.883191 & 3.070727 & 2.901887 \\
$\mathrm{C}$ & -2.04755 & 1.071542 & 1.175403 \\
$\mathrm{C}$ & -2.966607 & 1.870077 & 0.487536 \\
$\mathrm{C}$ & -4.167755 & 1.329765 & 0.024485 \\
$\mathrm{C}$ & -4.472345 & -0.009222 & 0.247826 \\
$\mathrm{C}$ & -3.576664 & -0.813037 & 0.955261 \\
$\mathrm{C}$ & -2.373815 & -0.280373 & 1.42185 \\
$\mathrm{H}$ & -1.700431 & -0.891277 & 2.032135 \\
$\mathrm{H}$ & -3.804744 & -1.865629 & 1.127875 \\
$\mathrm{H}$ & -5.396767 & -0.439453 & -0.140953 \\
$\mathrm{H}$ & -4.86414 & 1.962008 & -0.531261 \\
$\mathrm{H}$ & -2.725284 & 2.919704 & 0.296498 \\
$\mathrm{Pd}$ & -1.126692 & -1.195941 & -0.680073 \\
$\mathrm{H}$ & -0.176758 & -1.679686 & -1.781189 \\
$\mathrm{Cl}$ & -2.776909 & -2.572922 & -1.653422 \\
\hline & & &
\end{tabular}

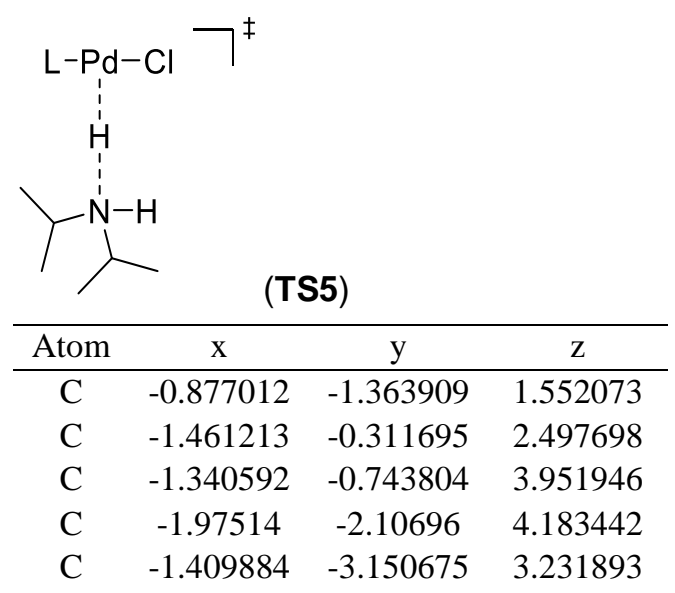




\begin{tabular}{|c|c|c|c|}
\hline C & -1.55246 & -2.713494 & 1.778097 \\
\hline 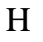 & -1.141571 & -3.485609 & 1.106579 \\
\hline 11 & -2.626788 & -2.631187 & 1.53592 \\
\hline $\mathrm{H}$ & -0.33956 & -3.312517 & 3.457567 \\
\hline $\mathrm{H}$ & -1.900206 & -4.124842 & 3.386405 \\
\hline $\mathrm{H}$ & -1.84437 & -2.424619 & 5.22972 \\
\hline $\mathrm{H}$ & -3.066156 & -2.030459 & 4.025415 \\
\hline $\mathrm{H}$ & -0.271195 & -0.785753 & 4.22752 \\
\hline $\mathrm{H}$ & -1.791246 & 0.012604 & 4.613152 \\
\hline $\mathrm{H}$ & -0.977252 & 0.666888 & 2.331106 \\
\hline $\mathrm{H}$ & -2.528848 & -0.162475 & 2.245959 \\
\hline $\mathrm{H}$ & 0.196795 & -1.476552 & 1.802453 \\
\hline $\mathrm{P}$ & -0.813569 & -0.689281 & -0.187007 \\
\hline $\mathrm{C}$ & -0.334243 & -2.146103 & -1.233461 \\
\hline $\mathrm{C}$ & -0.343563 & -1.741911 & -2.708303 \\
\hline $\mathrm{C}$ & 0.096484 & -2.886028 & -3.608526 \\
\hline $\mathrm{C}$ & 1.465204 & -3.411615 & -3.204361 \\
\hline $\mathrm{C}$ & 1.490296 & -3.818312 & -1.738244 \\
\hline $\mathrm{C}$ & 1.037649 & -2.683034 & -0.829707 \\
\hline $\mathrm{H}$ & 1.759165 & -1.849919 & -0.886692 \\
\hline $\mathrm{H}$ & 1.033394 & -3.013514 & 0.223516 \\
\hline $\mathrm{H}$ & 2.498217 & -4.156312 & -1.446859 \\
\hline $\mathrm{H}$ & 0.827731 & -4.690597 & -1.589777 \\
\hline $\mathrm{H}$ & 1.764296 & -4.25637 & -3.844148 \\
\hline $\mathrm{H}$ & 2.217882 & -2.62139 & -3.375599 \\
\hline $\mathrm{H}$ & 0.099515 & -2.562329 & -4.660794 \\
\hline $\mathrm{H}$ & -0.643771 & -3.704696 & -3.547365 \\
\hline $\mathrm{H}$ & 0.337336 & -0.877888 & -2.835474 \\
\hline $\mathrm{H}$ & -1.344975 & -1.381547 & -2.99778 \\
\hline $\mathrm{H}$ & -1.07209 & -2.9572 & -1.08896 \\
\hline $\mathrm{C}$ & -2.612011 & -0.479585 & -0.56722 \\
\hline $\mathrm{C}$ & -3.21674 & 0.799589 & -0.556787 \\
\hline $\mathrm{C}$ & -4.616367 & 0.89074 & -0.622199 \\
\hline $\mathrm{C}$ & -5.415359 & -0.240238 & -0.746746 \\
\hline $\mathrm{C}$ & -4.81942 & -1.497461 & -0.81869 \\
\hline $\mathrm{C}$ & -3.435631 & -1.606996 & -0.720788 \\
\hline $\mathrm{H}$ & -2.989633 & -2.603798 & -0.751839 \\
\hline $\mathrm{H}$ & -5.430394 & -2.395129 & -0.938847 \\
\hline $\mathrm{H}$ & -6.501435 & -0.138416 & -0.806451 \\
\hline $\mathrm{H}$ & -5.073354 & 1.884025 & -0.604106 \\
\hline $\mathrm{C}$ & -2.447813 & 2.066842 & -0.533901 \\
\hline $\mathrm{C}$ & -2.627865 & 3.007989 & 0.487369 \\
\hline $\mathrm{C}$ & -1.94844 & 4.225459 & 0.456412 \\
\hline $\mathrm{C}$ & -1.095629 & 4.528431 & -0.602381 \\
\hline $\mathrm{C}$ & -0.922735 & 3.608713 & -1.635329 \\
\hline $\mathrm{C}$ & -1.590292 & 2.386059 & -1.603331 \\
\hline $\mathrm{H}$ & -1.47485 & 1.675044 & -2.427529 \\
\hline $\mathrm{H}$ & -0.24319 & 3.832304 & -2.459178 \\
\hline $\mathrm{H}$ & -0.54526 & 5.470883 & -0.616114 \\
\hline $\mathrm{H}$ & -2.082467 & 4.940357 & 1.271821 \\
\hline $\mathrm{H}$ & -3.294643 & 2.769863 & 1.321673 \\
\hline
\end{tabular}




\begin{tabular}{cccc}
$\mathrm{Pd}$ & 0.537847 & 1.099479 & -0.381527 \\
$\mathrm{H}$ & 1.822242 & 0.238964 & 0.139397 \\
$\mathrm{Cl}$ & 2.146029 & 2.874998 & -0.550992 \\
$\mathrm{~N}$ & 3.260293 & -0.162009 & 0.702721 \\
$\mathrm{C}$ & 3.342742 & 0.678573 & 1.914526 \\
$\mathrm{C}$ & 4.68429 & 0.646104 & 2.626969 \\
$\mathrm{H}$ & 5.500614 & 1.032015 & 2.002082 \\
$\mathrm{H}$ & 4.644336 & 1.282117 & 3.522425 \\
$\mathrm{H}$ & 4.953839 & -0.369479 & 2.960205 \\
$\mathrm{C}$ & 2.207937 & 0.295495 & 2.840163 \\
$\mathrm{H}$ & 1.239935 & 0.427234 & 2.333599 \\
$\mathrm{H}$ & 2.290001 & -0.753994 & 3.173701 \\
$\mathrm{H}$ & 2.204223 & 0.924561 & 3.740222 \\
$\mathrm{H}$ & 3.159449 & 1.704198 & 1.547256 \\
$\mathrm{C}$ & 4.286824 & 0.057158 & -0.341586 \\
$\mathrm{C}$ & 5.505466 & -0.833935 & -0.144836 \\
$\mathrm{H}$ & 6.254782 & -0.643001 & -0.925963 \\
$\mathrm{H}$ & 5.999327 & -0.703252 & 0.825179 \\
$\mathrm{H}$ & 5.220983 & -1.895881 & -0.232509 \\
$\mathrm{C}$ & 3.72069 & -0.152105 & -1.735371 \\
$\mathrm{H}$ & 2.804976 & 0.435337 & -1.890595 \\
$\mathrm{H}$ & 4.455535 & 0.16206 & -2.489471 \\
$\mathrm{H}$ & 3.50517 & -1.216112 & -1.92294 \\
$\mathrm{H}$ & 4.564346 & 1.121029 & -0.250361 \\
$\mathrm{H}$ & 3.216189 & -1.152121 & 0.956731 \\
\hline & & & \\
\hline & & &
\end{tabular}

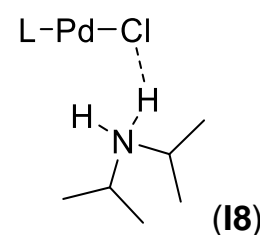

\begin{tabular}{cccc}
\hline Atom & $\mathrm{x}$ & $\mathrm{y}$ & $\mathrm{z}$ \\
\hline $\mathrm{C}$ & 1.00982 & 0.207069 & 1.825658 \\
$\mathrm{C}$ & 0.290522 & -1.072737 & 2.24385 \\
$\mathrm{C}$ & 0.066461 & -1.130813 & 3.74749 \\
$\mathrm{C}$ & 1.374774 & -0.975007 & 4.508212 \\
$\mathrm{C}$ & 2.096873 & 0.298672 & 4.096727 \\
$\mathrm{C}$ & 2.322401 & 0.356656 & 2.590163 \\
$\mathrm{H}$ & 2.828892 & 1.298876 & 2.323842 \\
$\mathrm{H}$ & 3.011224 & -0.455465 & 2.294663 \\
$\mathrm{H}$ & 1.495847 & 1.173617 & 4.406675 \\
$\mathrm{H}$ & 3.056591 & 0.390493 & 4.629411 \\
$\mathrm{H}$ & 1.199406 & -0.989908 & 5.595306 \\
$\mathrm{H}$ & 2.021796 & -1.84445 & 4.293782 \\
$\mathrm{H}$ & -0.620546 & -0.315451 & 4.046131 \\
$\mathrm{H}$ & -0.440411 & -2.069415 & 4.025151 \\
$\mathrm{H}$ & -0.660266 & -1.166141 & 1.687501 \\
$\mathrm{H}$ & 0.89651 & -1.943574 & 1.931185 \\
$\mathrm{H}$ & 0.356288 & 1.056159 & 2.106044 \\
$\mathrm{P}$ & 1.090552 & 0.333845 & -0.044665
\end{tabular}




\begin{tabular}{|c|c|c|c|}
\hline C & 2.033927 & 1.924419 & -0.296104 \\
\hline$C$ & 2.349864 & 2.119651 & -1.779635 \\
\hline $\mathrm{C}$ & 3.061912 & 3.43917 & -2.038728 \\
\hline C & 2.260014 & 4.614724 & -1.50222 \\
\hline C & 1.946398 & 4.434954 & -0.024847 \\
\hline $\mathrm{C}$ & 1.235608 & 3.114247 & 0.240078 \\
\hline $\mathrm{H}$ & 0.24122 & 3.117575 & -0.248701 \\
\hline $\mathrm{H}$ & 1.048406 & 2.998862 & 1.321879 \\
\hline $\mathrm{H}$ & 1.3392 & 5.274404 & 0.35002 \\
\hline $\mathrm{H}$ & 2.888065 & 4.4632 & 0.553692 \\
\hline $\mathrm{H}$ & 2.793631 & 5.563069 & -1.672393 \\
\hline $\mathrm{H}$ & 1.313398 & 4.692844 & -2.066466 \\
\hline $\mathrm{H}$ & 3.256299 & 3.560292 & -3.115874 \\
\hline $\mathrm{H}$ & 4.055345 & 3.422556 & -1.553197 \\
\hline $\mathrm{H}$ & 1.39664 & 2.090178 & -2.340465 \\
\hline $\mathrm{H}$ & 2.946118 & 1.274665 & -2.161461 \\
\hline $\mathrm{H}$ & 2.986195 & 1.894656 & 0.264699 \\
\hline $\mathrm{C}$ & 2.362347 & -0.970983 & -0.416402 \\
\hline $\mathrm{C}$ & 1.99132 & -2.297545 & -0.754277 \\
\hline $\mathrm{C}$ & 2.999191 & -3.266658 & -0.90259 \\
\hline $\mathrm{C}$ & 4.346953 & -2.957853 & -0.763276 \\
\hline $\mathrm{C}$ & 4.716948 & -1.650877 & -0.460489 \\
\hline $\mathrm{C}$ & 3.731924 & -0.683845 & -0.283573 \\
\hline $\mathrm{H}$ & 4.049011 & 0.327117 & -0.018897 \\
\hline $\mathrm{H}$ & 5.77047 & -1.381683 & -0.352456 \\
\hline $\mathrm{H}$ & 5.103904 & -3.733738 & -0.900125 \\
\hline $\mathrm{H}$ & 2.699432 & -4.286712 & -1.1588 \\
\hline $\mathrm{C}$ & 0.598831 & -2.776602 & -0.966639 \\
\hline $\mathrm{C}$ & 0.084895 & -3.787179 & -0.14277 \\
\hline $\mathrm{C}$ & -1.172638 & -4.341222 & -0.381883 \\
\hline $\mathrm{C}$ & -1.928909 & -3.903095 & -1.469072 \\
\hline $\mathrm{C}$ & -1.429943 & -2.904443 & -2.303459 \\
\hline $\mathrm{C}$ & -0.18048 & -2.335478 & -2.049432 \\
\hline $\mathrm{H}$ & 0.224448 & -1.58211 & -2.73161 \\
\hline $\mathrm{H}$ & -2.01702 & -2.546191 & -3.151786 \\
\hline $\mathrm{H}$ & -2.911098 & -4.340994 & -1.667292 \\
\hline $\mathrm{H}$ & -1.55486 & -5.126466 & 0.275681 \\
\hline $\mathrm{H}$ & 0.688703 & -4.145478 & 0.697163 \\
\hline $\mathrm{Pd}$ & -0.795452 & 0.296964 & -1.194157 \\
\hline $\mathrm{H}$ & -3.499538 & 0.79754 & -0.523384 \\
\hline $\mathrm{Cl}$ & -2.891628 & 0.536035 & -2.488404 \\
\hline $\mathrm{N}$ & -3.250834 & 0.798339 & 0.501857 \\
\hline $\mathrm{C}$ & -3.999491 & -0.314518 & 1.157534 \\
\hline $\mathrm{C}$ & -3.691842 & -0.427125 & 2.633639 \\
\hline $\mathrm{H}$ & -3.974236 & 0.469144 & 3.202515 \\
\hline $\mathrm{H}$ & -4.254025 & -1.269042 & 3.058032 \\
\hline $\mathrm{H}$ & -2.624187 & -0.629762 & 2.805139 \\
\hline $\mathrm{C}$ & -3.682525 & -1.582837 & 0.393109 \\
\hline $\mathrm{H}$ & -3.864237 & -1.463757 & -0.684162 \\
\hline $\mathrm{H}$ & -2.619749 & -1.852188 & 0.506143 \\
\hline $\mathrm{H}$ & -4.286464 & -2.419645 & 0.767835 \\
\hline
\end{tabular}




\begin{tabular}{cccc}
$\mathrm{H}$ & -5.066362 & -0.055605 & 1.02939 \\
$\mathrm{C}$ & -3.359686 & 2.188336 & 1.052435 \\
$\mathrm{C}$ & -2.208858 & 2.463537 & 1.999397 \\
$\mathrm{H}$ & -2.29139 & 3.475256 & 2.417266 \\
$\mathrm{H}$ & -2.152506 & 1.757108 & 2.83789 \\
$\mathrm{H}$ & -1.262001 & 2.404821 & 1.438419 \\
$\mathrm{C}$ & -3.3633 & 3.168761 & -0.102757 \\
$\mathrm{H}$ & -4.186525 & 2.982506 & -0.804465 \\
$\mathrm{H}$ & -3.451582 & 4.195937 & 0.274054 \\
$\mathrm{H}$ & -2.42564 & 3.082568 & -0.674154 \\
$\mathrm{H}$ & -4.324789 & 2.230296 & 1.589016 \\
$\mathrm{H}$ & -2.213419 & 0.546762 & 0.387375 \\
\hline
\end{tabular}<smiles>[R]C(C)(N)C([3H])(Cl)[PH+]([3H])[PH2]=P[SnH3]</smiles>

\begin{tabular}{cccc}
\hline Atom & $\mathrm{x}$ & $\mathrm{y}$ & $\mathrm{z}$ \\
\hline $\mathrm{C}$ & 0.990456 & 1.96162 & -0.811946 \\
$\mathrm{C}$ & 0.665829 & 3.162688 & 0.07456 \\
$\mathrm{C}$ & 0.52417 & 4.419059 & -0.773274 \\
$\mathrm{C}$ & 1.789778 & 4.687644 & -1.574617 \\
$\mathrm{C}$ & 2.190664 & 3.480148 & -2.408971 \\
$\mathrm{C}$ & 2.29675 & 2.217433 & -1.562294 \\
$\mathrm{H}$ & 2.584291 & 1.359212 & -2.19172 \\
$\mathrm{H}$ & 3.106259 & 2.336709 & -0.818473 \\
$\mathrm{H}$ & 1.438793 & 3.315059 & -3.202227 \\
$\mathrm{H}$ & 3.142031 & 3.666455 & -2.932001 \\
$\mathrm{H}$ & 1.667383 & 5.575126 & -2.214921 \\
$\mathrm{H}$ & 2.611525 & 4.930301 & -0.876708 \\
$\mathrm{H}$ & -0.335711 & 4.294861 & -1.45677 \\
$\mathrm{H}$ & 0.278639 & 5.281784 & -0.134872 \\
$\mathrm{H}$ & -0.249791 & 2.981576 & 0.656172 \\
$\mathrm{H}$ & 1.479823 & 3.305175 & 0.808538 \\
$\mathrm{H}$ & 0.166541 & 1.86808 & -1.543735 \\
$\mathrm{P}$ & 0.931891 & 0.344541 & 0.090708 \\
$\mathrm{C}$ & 1.400775 & -0.921067 & -1.185626 \\
$\mathrm{C}$ & 1.181842 & -2.352494 & -0.690467 \\
$\mathrm{C}$ & 1.5947 & -3.373479 & -1.738294 \\
$\mathrm{C}$ & 0.856561 & -3.157617 & -3.049374 \\
$\mathrm{C}$ & 1.030622 & -1.729423 & -3.539287 \\
$\mathrm{C}$ & 0.610259 & -0.715906 & -2.483 \\
$\mathrm{H}$ & -0.466357 & -0.840219 & -2.261234 \\
$\mathrm{H}$ & 0.728543 & 0.30342 & -2.882022 \\
$\mathrm{H}$ & 0.463399 & -1.559145 & -4.467857 \\
$\mathrm{H}$ & 2.092527 & -1.556339 & -3.795674 \\
$\mathrm{H}$ & 1.194542 & -3.874415 & -3.813988 \\
$\mathrm{H}$ & -0.220015 & -3.359487 & -2.899768 \\
$\mathrm{H}$ & 1.41993 & -4.390585 & -1.354361 \\
$\mathrm{H}$ & 2.682811 & -3.297277 & -1.915042 \\
$\mathrm{H}$ & 0.107408 & -2.477425 & -0.455922 \\
& & &
\end{tabular}




\begin{tabular}{|c|c|c|c|}
\hline $\mathrm{H}$ & 1.690364 & -2.527157 & 0.267118 \\
\hline $\mathrm{H}$ & 2.472329 & -0.77985 & -1.412255 \\
\hline $\mathrm{C}$ & 2.198947 & 0.583592 & 1.403847 \\
\hline C & 3.586182 & 0.323958 & 1.355113 \\
\hline$C$ & 4.395134 & 0.78824 & 2.405265 \\
\hline $\mathrm{C}$ & 3.866422 & 1.476037 & 3.491254 \\
\hline C & 2.493068 & 1.696383 & 3.559321 \\
\hline $\mathrm{C}$ & 1.678057 & 1.247739 & 2.528781 \\
\hline $\mathrm{H}$ & 0.596251 & 1.405193 & 2.587311 \\
\hline $\mathrm{H}$ & 2.052059 & 2.206198 & 4.418416 \\
\hline $\mathrm{H}$ & 4.52464 & 1.819091 & 4.292877 \\
\hline $\mathrm{H}$ & 5.467292 & 0.57776 & 2.362369 \\
\hline C & 4.260423 & -0.494262 & 0.310333 \\
\hline $\mathrm{C}$ & 4.255239 & -1.890848 & 0.430762 \\
\hline $\mathrm{C}$ & 4.907478 & -2.686713 & -0.508423 \\
\hline $\mathrm{C}$ & 5.578283 & -2.099736 & -1.581203 \\
\hline $\mathrm{C}$ & 5.615058 & -0.710463 & -1.69374 \\
\hline $\mathrm{C}$ & 4.971525 & 0.086769 & -0.748114 \\
\hline $\mathrm{H}$ & 5.018119 & 1.175474 & -0.831375 \\
\hline $\mathrm{H}$ & 6.156418 & -0.241563 & -2.519129 \\
\hline $\mathrm{H}$ & 6.084986 & -2.724217 & -2.32083 \\
\hline $\mathrm{H}$ & 4.889895 & -3.774157 & -0.401511 \\
\hline $\mathrm{H}$ & 3.734106 & -2.348586 & 1.276403 \\
\hline $\mathrm{Pd}$ & -1.056282 & -0.316421 & 0.951893 \\
\hline $\mathrm{C}$ & -2.093412 & 1.143012 & 0.033648 \\
\hline $\mathrm{C}$ & -2.416078 & 1.241998 & -1.325935 \\
\hline $\mathrm{C}$ & -3.274147 & 2.241679 & -1.79063 \\
\hline $\mathrm{C}$ & -3.821969 & 3.171081 & -0.906816 \\
\hline $\mathrm{C}$ & -3.50225 & 3.093919 & 0.448326 \\
\hline $\mathrm{C}$ & -2.641332 & 2.09508 & 0.910303 \\
\hline $\mathrm{H}$ & -2.385315 & 2.07221 & 1.977447 \\
\hline $\mathrm{H}$ & -3.916474 & 3.82108 & 1.15303 \\
\hline $\mathrm{H}$ & -4.492694 & 3.952604 & -1.272399 \\
\hline $\mathrm{H}$ & -3.523757 & 2.285587 & -2.854975 \\
\hline $\mathrm{H}$ & -2.019417 & 0.516484 & -2.042744 \\
\hline $\mathrm{Cl}$ & 0.052521 & -1.836599 & 2.504469 \\
\hline $\mathrm{C}$ & -3.182309 & -1.518381 & 1.354419 \\
\hline $\mathrm{C}$ & -4.08341 & -1.206187 & 0.219084 \\
\hline $\mathrm{C}$ & -3.91552 & -1.812367 & -1.037255 \\
\hline $\mathrm{C}$ & -4.745928 & -1.482334 & -2.101823 \\
\hline $\mathrm{C}$ & -5.754243 & -0.530716 & -1.941806 \\
\hline $\mathrm{C}$ & -5.921689 & 0.081925 & -0.701912 \\
\hline $\mathrm{C}$ & -5.101501 & -0.254583 & 0.372562 \\
\hline $\mathrm{H}$ & -5.246816 & 0.24253 & 1.333861 \\
\hline $\mathrm{H}$ & -6.700412 & 0.835832 & -0.563263 \\
\hline $\mathrm{H}$ & -6.402078 & -0.266409 & -2.780454 \\
\hline $\mathrm{H}$ & -4.599203 & -1.968841 & -3.069273 \\
\hline $\mathrm{H}$ & -3.112326 & -2.541162 & -1.187789 \\
\hline $\mathrm{C}$ & -3.460511 & -1.032815 & 2.756461 \\
\hline $\mathrm{H}$ & -4.42284 & -1.409056 & 3.142843 \\
\hline $\mathrm{H}$ & -2.652636 & -1.338391 & 3.433776 \\
\hline
\end{tabular}




\begin{tabular}{cccc}
$\mathrm{H}$ & -3.504033 & 0.064644 & 2.764346 \\
$\mathrm{~N}$ & -2.667738 & -2.751661 & 1.287103 \\
$\mathrm{~N}$ & -2.193236 & -3.775826 & 1.181423 \\
\hline
\end{tabular}

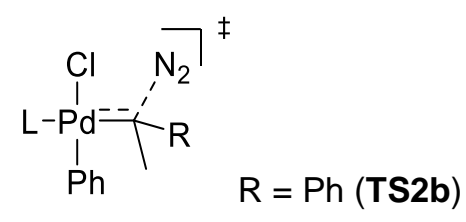

\begin{tabular}{cccc}
\hline Atom & $\mathrm{x}$ & $\mathrm{y}$ & $\mathrm{z}$ \\
\hline $\mathrm{C}$ & 1.236215 & 1.837548 & -0.915169 \\
$\mathrm{C}$ & 1.289301 & 3.122518 & -0.088636 \\
$\mathrm{C}$ & 1.34543 & 4.339365 & -1.000879 \\
$\mathrm{C}$ & 2.542447 & 4.26845 & -1.937924 \\
$\mathrm{C}$ & 2.567109 & 2.960873 & -2.715958 \\
$\mathrm{C}$ & 2.483288 & 1.751976 & -1.791187 \\
$\mathrm{H}$ & 2.515755 & 0.820346 & -2.378976 \\
$\mathrm{H}$ & 3.371196 & 1.731842 & -1.136012 \\
$\mathrm{H}$ & 1.711981 & 2.933485 & -3.41574 \\
$\mathrm{H}$ & 3.470825 & 2.898728 & -3.342723 \\
$\mathrm{H}$ & 2.550754 & 5.12749 & -2.626818 \\
$\mathrm{H}$ & 3.470523 & 4.350188 & -1.343247 \\
$\mathrm{H}$ & 0.411032 & 4.388783 & -1.588915 \\
$\mathrm{H}$ & 1.375738 & 5.263554 & -0.402537 \\
$\mathrm{H}$ & 0.429204 & 3.184762 & 0.594765 \\
$\mathrm{H}$ & 2.189306 & 3.102861 & 0.553147 \\
$\mathrm{H}$ & 0.349756 & 1.906694 & -1.573806 \\
$\mathrm{P}$ & 0.851486 & 0.349019 & 0.12904 \\
$\mathrm{C}$ & 1.104684 & -1.092692 & -1.007643 \\
$\mathrm{C}$ & 0.734428 & -2.422278 & -0.350994 \\
$\mathrm{C}$ & 0.980354 & -3.591477 & -1.291584 \\
$\mathrm{C}$ & 0.231571 & -3.421633 & -2.60487 \\
$\mathrm{C}$ & 0.539613 & -2.077751 & -3.246038 \\
$\mathrm{C}$ & 0.270578 & -0.929388 & -2.283337 \\
$\mathrm{H}$ & -0.799396 & -0.930703 & -1.999387 \\
$\mathrm{H}$ & 0.455209 & 0.036743 & -2.77944 \\
$\mathrm{H}$ & -0.046938 & -1.942764 & -4.168399 \\
$\mathrm{H}$ & 1.601769 & -2.047612 & -3.553523 \\
$\mathrm{H}$ & 0.465018 & -4.245588 & -3.297491 \\
$\mathrm{H}$ & -0.855128 & -3.480614 & -2.41503 \\
$\mathrm{H}$ & 0.691771 & -4.534444 & -0.79955 \\
$\mathrm{H}$ & 2.063515 & -3.673788 & -1.495438 \\
$\mathrm{H}$ & -0.335651 & -2.382056 & -0.079973 \\
$\mathrm{H}$ & 1.257675 & -2.558943 & 0.605772 \\
$\mathrm{H}$ & 2.172603 & -1.114168 & -1.291632 \\
$\mathrm{C}$ & 2.123504 & 0.433609 & 1.458318 \\
$\mathrm{C}$ & 3.451262 & -0.05219 & 1.467042 \\
$\mathrm{C}$ & 4.286924 & 0.292751 & 2.542904 \\
$\mathrm{C}$ & 3.845345 & 1.085885 & 3.595281 \\
$\mathrm{C}$ & 2.528897 & 1.538603 & 3.604029 \\
$\mathrm{C}$ & 1.6867 & 1.204885 & 2.551748
\end{tabular}




\begin{tabular}{|c|c|c|c|}
\hline & 0.644815 & 685 & 47 \\
\hline & 2.151476 & 2.140229 & 4.433523 \\
\hline & .523983 & 332635 & 415095 \\
\hline & .310383 & -0.092575 & 544364 \\
\hline & 4.040883 & -0.975005 & 155902 \\
\hline $\mathrm{C}$ & 3.881491 & -2.35971 & 507269 \\
\hline $\mathrm{C}$ & 4.46203 & -3.247539 & 0.296639 \\
\hline $\mathrm{C}$ & 5.21941 & -2.766943 & 6405 \\
\hline c & 5.421318 & -1.394321 & -1.500119 \\
\hline C & .848154 & -0.5 & 9261 \\
\hline $\mathrm{H}$ & 5.03 & 81 & 4681 \\
\hline $\mathrm{H}$ & 6.039814 & -1.009585 & 4734 \\
\hline I & 669344 & 2498 & 76346 \\
\hline $\mathrm{H}$ & 322407 & 3273 & -0.163538 \\
\hline & .300208 & -2. & 296 \\
\hline $\mathrm{Pd}$ & 397 & & 168 \\
\hline $\mathrm{C}$ & 206 & & 751 \\
\hline $\mathrm{C}$ & 877 & & \\
\hline $\mathrm{C}$ & -2.827806 & 795 & 1298 \\
\hline $\mathrm{C}$ & 061 & 3.8 & 6622 \\
\hline $\mathrm{C}$ & -2.5 & 4.0 & -0 . \\
\hline $\mathrm{C}$ & -2.06 & 3.0 & 356 \\
\hline $\mathrm{H}$ & 34 & & 98 \\
\hline $\mathrm{H}$ & -2.5 & 5.0 & 043 \\
\hline $\mathrm{H}$ & -3.26308 & & +353 \\
\hline $\mathrm{H}$ & -3.1 & 63 & 9344 \\
\hline $\mathrm{H}$ & -2.3 & 0.5 & -2.097601 \\
\hline $\mathrm{C}$ & -3.444835 & 588 & 1.106961 \\
\hline $\mathrm{C}$ & 18 & -1.2 & 486 \\
\hline $\mathrm{C}$ & -3.0 & -2. & 37 \\
\hline $\mathrm{C}$ & -3.26 & -3. & 4953 \\
\hline $\mathrm{C}$ & -4.10534 & -3.137553 & -1.888439 \\
\hline $\mathrm{C}$ & -4.775421 & -1.918976 & -1.957584 \\
\hline $\mathrm{C}$ & -4.617798 & -0.968155 & 9092 \\
\hline $\mathrm{H}$ & -5.151447 & 7989 & -1.022279 \\
\hline $\mathrm{H}$ & -5.43 & -1. & -2 \\
\hline $\mathrm{H}$ & -4.23 & -3.8 & -2.674552 \\
\hline $\mathrm{H}$ & -2.732618 & -4.355232 & -0.738503 \\
\hline $\mathrm{H}$ & -2.37714 & -2.630476 & 1.008944 \\
\hline $\mathrm{C}$ & -4.468938 & 4294 & 1.273074 \\
\hline $\mathrm{H}$ & -5.494411 & 0.558854 & 1.387475 \\
\hline $\mathrm{H}$ & -4.232611 & 1.603633 & 2.116926 \\
\hline $\mathrm{H}$ & -4.451476 & 1.573394 & 0.37389 \\
\hline $\mathrm{Cl}$ & -0.571629 & -1.327741 & 2.635289 \\
\hline $\mathrm{N}$ & -3.654108 & -1.000022 & 2.690227 \\
\hline $\mathrm{N}$ & -3.162048 & -1.554372 & 3.528476 \\
\hline
\end{tabular}




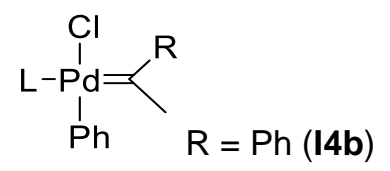

\begin{tabular}{|c|c|c|c|}
\hline Atom & $\mathrm{x}$ & $\mathrm{y}$ & $\mathrm{Z}$ \\
\hline $\mathrm{Pd}$ & -1.443871 & 0.17704 & 0.625188 \\
\hline $\mathrm{C}$ & -1.95154 & 1.892057 & -0.324792 \\
\hline $\mathrm{C}$ & -2.068408 & 2.013198 & -1.718309 \\
\hline $\mathrm{C}$ & -2.406463 & 3.231496 & -2.315225 \\
\hline $\mathrm{C}$ & -2.647863 & 4.359474 & -1.532531 \\
\hline $\mathrm{C}$ & -2.557112 & 4.253572 & -0.144579 \\
\hline $\mathrm{C}$ & -2.219477 & 3.035285 & 0.448245 \\
\hline $\mathrm{H}$ & -2.155222 & 2.9841 & 1.541666 \\
\hline $\mathrm{H}$ & -2.753116 & 5.126472 & 0.485359 \\
\hline $\mathrm{H}$ & -2.911646 & 5.311592 & -1.9998 \\
\hline $\mathrm{H}$ & -2.486226 & 3.29441 & -3.404611 \\
\hline $\mathrm{H}$ & -1.896764 & 1.146769 & -2.365803 \\
\hline $\mathrm{C}$ & -3.282273 & -0.317319 & 1.186313 \\
\hline $\mathrm{C}$ & -4.112514 & -1.210463 & 0.393208 \\
\hline $\mathrm{C}$ & -3.64027 & -1.684321 & -0.851078 \\
\hline $\mathrm{C}$ & -4.415125 & -2.518129 & -1.643284 \\
\hline $\mathrm{C}$ & -5.697115 & -2.883959 & -1.224257 \\
\hline $\mathrm{C}$ & -6.193835 & -2.414647 & -0.007611 \\
\hline $\mathrm{C}$ & -5.409396 & -1.594888 & 0.795156 \\
\hline $\mathrm{H}$ & -5.809133 & -1.245402 & 1.749164 \\
\hline $\mathrm{H}$ & -7.197452 & -2.697234 & 0.318398 \\
\hline $\mathrm{H}$ & -6.313138 & -3.53 & -1.851342 \\
\hline $\mathrm{H}$ & -4.027779 & -2.879911 & -2.598415 \\
\hline $\mathrm{H}$ & -2.639072 & -1.375812 & -1.171089 \\
\hline $\mathrm{C}$ & -3.806408 & 0.244432 & 2.44845 \\
\hline $\mathrm{H}$ & -4.424469 & -0.43828 & 3.051828 \\
\hline $\mathrm{H}$ & -3.011306 & 0.65496 & 3.081856 \\
\hline $\mathrm{H}$ & -4.445875 & 1.098993 & 2.15776 \\
\hline $\mathrm{P}$ & 0.900835 & 0.307836 & 0.095013 \\
\hline $\mathrm{C}$ & 1.426523 & 1.937485 & -0.610926 \\
\hline $\mathrm{C}$ & 1.29709 & 3.062155 & 0.416524 \\
\hline $\mathrm{C}$ & 1.45045 & 4.417691 & -0.258423 \\
\hline $\mathrm{C}$ & 2.77 & 4.518438 & -1.010255 \\
\hline $\mathrm{C}$ & 2.948694 & 3.365402 & -1.988329 \\
\hline $\mathrm{C}$ & 2.786522 & 2.017805 & -1.295165 \\
\hline $\mathrm{H}$ & 2.936216 & 1.190231 & -2.008643 \\
\hline $\mathrm{H}$ & 3.573863 & 1.90965 & -0.529104 \\
\hline $\mathrm{H}$ & 2.195966 & 3.44684 & -2.793587 \\
\hline $\mathrm{H}$ & 3.930135 & 3.425941 & -2.484905 \\
\hline $\mathrm{H}$ & 2.847557 & 5.484015 & -1.534192 \\
\hline $\mathrm{H}$ & 3.602447 & 4.50296 & -0.283312 \\
\hline $\mathrm{H}$ & 0.607954 & 4.560388 & -0.959234 \\
\hline $\mathrm{H}$ & 1.364402 & 5.226132 & 0.484483 \\
\hline $\mathrm{H}$ & 0.33032 & 3.000248 & 0.939752 \\
\hline $\mathrm{H}$ & 2.077635 & 2.936888 & 1.19023 \\
\hline $\mathrm{H}$ & 0.642304 & 2.11109 & -1.374166 \\
\hline
\end{tabular}




\begin{tabular}{cccc}
$\mathrm{C}$ & 1.280126 & -0.961718 & -1.19738 \\
$\mathrm{C}$ & 0.754769 & -2.331902 & -0.763013 \\
$\mathrm{C}$ & 1.010431 & -3.390073 & -1.82404 \\
$\mathrm{C}$ & 0.396288 & -2.990787 & -3.157374 \\
$\mathrm{C}$ & 0.881778 & -1.618296 & -3.594676 \\
$\mathrm{C}$ & 0.625133 & -0.566502 & -2.524596 \\
$\mathrm{H}$ & -0.464051 & -0.464331 & -2.356631 \\
$\mathrm{H}$ & 0.971613 & 0.420017 & -2.872485 \\
$\mathrm{H}$ & 0.406186 & -1.317992 & -4.541585 \\
$\mathrm{H}$ & 1.967199 & -1.662286 & -3.800704 \\
$\mathrm{H}$ & 0.612468 & -3.744277 & -3.930981 \\
$\mathrm{H}$ & -0.704706 & -2.968472 & -3.055876 \\
$\mathrm{H}$ & 0.616768 & -4.362239 & -1.488453 \\
$\mathrm{H}$ & 2.099994 & -3.527569 & -1.950469 \\
$\mathrm{H}$ & -0.33153 & -2.245585 & -0.576717 \\
$\mathrm{H}$ & 1.1758 & -2.629996 & 0.209476 \\
$\mathrm{H}$ & 2.371418 & -1.021873 & -1.356238 \\
$\mathrm{C}$ & 1.919038 & 0.038526 & 1.606439 \\
$\mathrm{C}$ & 3.139295 & -0.660324 & 1.763484 \\
$\mathrm{C}$ & 3.702031 & -0.756331 & 3.047047 \\
$\mathrm{C}$ & 3.111206 & -0.163915 & 4.157196 \\
$\mathrm{C}$ & 1.913848 & 0.529626 & 4.006027 \\
$\mathrm{C}$ & 1.326293 & 0.608089 & 2.750018 \\
$\mathrm{H}$ & 0.355415 & 1.104521 & 2.641588 \\
$\mathrm{H}$ & 1.42257 & 0.988372 & 4.866728 \\
$\mathrm{H}$ & 3.580714 & -0.25519 & 5.139428 \\
$\mathrm{H}$ & 4.637434 & -1.311401 & 3.160077 \\
$\mathrm{C}$ & 3.883863 & -1.346205 & 0.670325 \\
$\mathrm{C}$ & 3.803525 & -2.739562 & 0.537317 \\
$\mathrm{C}$ & 4.513062 & -3.403497 & -0.461628 \\
$\mathrm{C}$ & 5.328077 & -2.687336 & -1.337633 \\
$\mathrm{C}$ & 5.449164 & -1.306271 & -1.188954 \\
$\mathrm{C}$ & 4.740242 & -0.644422 & -0.187639 \\
$\mathrm{H}$ & 4.85964 & 0.433004 & -0.060214 \\
$\mathrm{H}$ & 6.108955 & -0.739047 & -1.850195 \\
$\mathrm{H}$ & 5.881977 & -3.207137 & -2.122861 \\
$\mathrm{H}$ & 4.427429 & -4.488892 & -0.555465 \\
$\mathrm{H}$ & 3.168437 & -3.304901 & 1.225014 \\
$\mathrm{Cl}$ & -1.446686 & -1.864782 & 2.062713 \\
\hline & & & \\
\hline
\end{tabular}

\begin{tabular}{|c|c|c|c|}
\hline & & $\mathrm{Ph}(\mathbf{T S} 3 \mathrm{~b}$ & \\
\hline Atom & $\mathrm{x}$ & $\mathrm{y}$ & $\mathrm{z}$ \\
\hline $\mathrm{C}$ & -3.995661 & 1.056762 & 2.11558 \\
\hline $\mathrm{C}$ & -3.337478 & 0.084695 & 1.209101 \\
\hline $\mathrm{C}$ & -4.177209 & -0.905002 & 0.542525 \\
\hline $\mathrm{C}$ & -3.57972 & -1.950687 & -0.197629 \\
\hline $\mathrm{C}$ & -4.347663 & -2.941611 & -0.791364 \\
\hline
\end{tabular}




\begin{tabular}{|c|c|c|c|}
\hline$c$ & 643 & 238 & 107 \\
\hline $\mathrm{C}$ & -6.353289 & -1.899212 & 0.068053 \\
\hline & -5.583938 & -0.905343 & 60645 \\
\hline & -6.081896 & -0.115466 & 1.226741 \\
\hline & -7.440376 & -1.88 & 173354 \\
\hline & -6.34501 & -3.699347 & -1.125984 \\
\hline$\Pi$ & -3.863278 & -3.744778 & -1.351096 \\
\hline $\mathrm{H}$ & -2.486495 & -1.967609 & -0.274618 \\
\hline $\mathrm{Pd}$ & -1.388904 & 0.051862 & 1.025768 \\
\hline $\mathrm{C}$ & -2.314961 & 1.352732 & 6571 \\
\hline $\mathrm{C}$ & -2.670627 & 0.9 & -1.6 \\
\hline $\mathrm{C}$ & -2.987814 & & \\
\hline $\mathrm{C}$ & -3.00 & & \\
\hline $\mathrm{C}$ & -2.708789 & 3.67 & -0.984082 \\
\hline $\mathrm{C}$ & -2.382309 & 2.72 & -0.019431 \\
\hline $\mathrm{H}$ & -2.161462 & 3.05 & 317 \\
\hline $\mathrm{r}$ & -2.73 & 4.7 & 677 \\
\hline $\mathrm{H}$ & -3.2 & 4.0 & 886 \\
\hline $\mathrm{H}$ & -3.2 & 1.5 & \\
\hline $\mathrm{H}$ & -2.708075 & & \\
\hline $\mathrm{P}$ & 0.881992 & & \\
\hline $\mathrm{C}$ & 1.126153 & 1.7 & -0.8 \\
\hline $\mathrm{C}$ & 1.02 & 3.0 & 06 \\
\hline $\mathrm{C}$ & 0.99 & 4.3 & 502 \\
\hline $\mathrm{C}$ & 2.2 & & \\
\hline $\mathrm{C}$ & 2.37 & & 368 \\
\hline $\mathrm{C}$ & & & 877 \\
\hline H & 2.52 & 0.93 & 9522 \\
\hline & 3.26 & & 188 \\
\hline & & & 253 \\
\hline $\mathrm{H}$ & 66 & & \\
\hline $\mathrm{H}$ & 2.15 & & \\
\hline $\mathrm{H}$ & 3.12 & & 075 \\
\hline $\mathrm{H}$ & 0.07 & 4.28 & 1917 \\
\hline H & & 5.21 & 3223 \\
\hline & 33 & 3.03 & 868 \\
\hline & 6 & 3.1 & 34 \\
\hline $\mathrm{H}$ & 0.24 & 6 & -1.5 \\
\hline $\mathrm{C}$ & 1.198056 & -1.140234 & -0.979422 \\
\hline $\mathrm{C}$ & 0.87 & -2.472313 & -0.302251 \\
\hline $\mathrm{C}$ & 1.079451 & -3.649337 & -1.239828 \\
\hline $\mathrm{C}$ & 0.263 & -3.49015 & 3367 \\
\hline C & 0.5 & -2.1 & -3. \\
\hline $\mathrm{C}$ & 0.350 & -0.990028 & -2.246315 \\
\hline $\mathrm{H}$ & -0.71 & -0.94306 & .9518 \\
\hline 11 & 0.560252 & -0.04185 & -2.766692 \\
\hline & -0.0 & -2.03 & -4.09728 \\
\hline & 16 & -2.160577 & -3.532941 \\
\hline $\mathrm{H}$ & 0.440427 & -4.329848 & -3.203689 \\
\hline $\mathrm{H}$ & -0.813166 & -3.525975 & -2.260937 \\
\hline 11 & 0.824275 & -4.589352 & -0.725845 \\
\hline
\end{tabular}




\begin{tabular}{cccc}
$\mathrm{H}$ & 2.150764 & -3.724612 & -1.501434 \\
$\mathrm{H}$ & -0.182873 & -2.442679 & 0.033569 \\
$\mathrm{H}$ & 1.442798 & -2.592931 & 0.628666 \\
$\mathrm{H}$ & 2.261102 & -1.135884 & -1.278033 \\
$\mathrm{C}$ & 2.19307 & 0.388477 & 1.471929 \\
$\mathrm{C}$ & 3.532249 & -0.06519 & 1.449116 \\
$\mathrm{C}$ & 4.375194 & 0.26542 & 2.523369 \\
$\mathrm{C}$ & 3.931166 & 1.019685 & 3.603267 \\
$\mathrm{C}$ & 2.605707 & 1.443729 & 3.641916 \\
$\mathrm{C}$ & 1.754874 & 1.117697 & 2.593765 \\
$\mathrm{H}$ & 0.704397 & 1.422208 & 2.63971 \\
$\mathrm{H}$ & 2.226997 & 2.012669 & 4.493681 \\
$\mathrm{H}$ & 4.615766 & 1.258477 & 4.420559 \\
$\mathrm{H}$ & 5.407427 & -0.095001 & 2.499288 \\
$\mathrm{C}$ & 4.128626 & -0.938733 & 0.398726 \\
$\mathrm{C}$ & 4.069124 & -2.331695 & 0.545359 \\
$\mathrm{C}$ & 4.648491 & -3.174773 & -0.401015 \\
$\mathrm{C}$ & 5.307036 & -2.639545 & -1.507408 \\
$\mathrm{C}$ & 5.40854 & -1.255657 & -1.64291 \\
$\mathrm{C}$ & 4.834556 & -0.413422 & -0.691486 \\
$\mathrm{H}$ & 4.939696 & 0.669084 & -0.79226 \\
$\mathrm{H}$ & 5.947228 & -0.826037 & -2.491199 \\
$\mathrm{H}$ & 5.756867 & -3.299979 & -2.252514 \\
$\mathrm{H}$ & 4.584974 & -4.258108 & -0.271529 \\
$\mathrm{H}$ & 3.561017 & -2.752887 & 1.417081 \\
$\mathrm{Cl}$ & -0.54807 & -1.40845 & 2.734815 \\
$\mathrm{H}$ & -4.386102 & 0.485824 & 2.975493 \\
$\mathrm{H}$ & -3.302344 & 1.803989 & 2.517588 \\
$\mathrm{H}$ & -4.856143 & 1.58123 & 1.6677 \\
\hline & & &
\end{tabular}

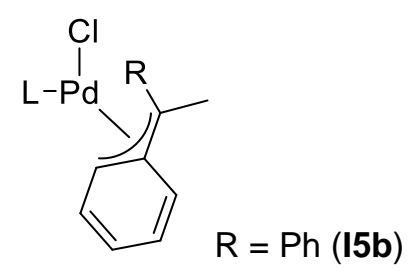

\begin{tabular}{cccc}
\hline Atom & $\mathrm{x}$ & $\mathrm{y}$ & $\mathrm{z}$ \\
\hline $\mathrm{C}$ & -3.042605 & 1.517548 & -0.549132 \\
$\mathrm{C}$ & -3.329444 & 1.149266 & -1.901336 \\
$\mathrm{C}$ & -2.697162 & 1.760036 & -2.960614 \\
$\mathrm{C}$ & -1.715872 & 2.753999 & -2.748812 \\
$\mathrm{C}$ & -1.414371 & 3.147602 & -1.4639 \\
$\mathrm{C}$ & -2.049969 & 2.543977 & -0.350135 \\
$\mathrm{H}$ & -1.969915 & 3.050826 & 0.616454 \\
$\mathrm{H}$ & -0.696432 & 3.953216 & -1.288231 \\
$\mathrm{H}$ & -1.224728 & 3.228154 & -3.601921 \\
$\mathrm{H}$ & -2.971293 & 1.482231 & -3.981628 \\
$\mathrm{H}$ & -4.106612 & 0.40589 & -2.08746 \\
$\mathrm{C}$ & -3.554389 & 0.823825 & 0.624963 \\
$\mathrm{C}$ & -4.22028 & -0.490319 & 0.45569 \\
\hline
\end{tabular}




\begin{tabular}{|c|c|c|c|}
\hline & 764 & 3916 & 331 \\
\hline & -4.296255 & -2.711574 & -0.558612 \\
\hline & -5.431371 & -3.033924 & 0.18794 \\
\hline & -5.949794 & -2.094259 & 1.07513 \\
\hline & 5.349729 & -0.843684 & 1.212579 \\
\hline & -5.776384 & -0.132103 & 1.921999 \\
\hline$\Pi$ & -6.830292 & -2.336527 & 1.675244 \\
\hline $\mathrm{H}$ & -5.898313 & -4.016459 & 0.087846 \\
\hline & -3.858261 & -3.446432 & -1.239207 \\
\hline & -2.789876 & -1.239471 & 224 \\
\hline & -3.932366 & 1.607051 & 1.851967 \\
\hline $\mathrm{H}$ & 4.98947 & 1.923683 & 1.811896 \\
\hline $\mathrm{H}$ & -3.803829 & & 2.758397 \\
\hline $\mathrm{H}$ & -3.337981 & 438 & 1.977072 \\
\hline c & 1.724701 & 1.940928 & -0.528513 \\
\hline c & 1.59 & & \\
\hline & 2.11 & 955 & -0.162165 \\
\hline & 3.54 & & -0.6 \\
\hline 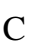 & 3.6 & & \\
\hline 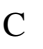 & 3.166276 & & -1.002584 \\
\hline I & 3.26 & & -1.715844 \\
\hline $\mathrm{H}$ & 3.78 & & 7877 \\
\hline $\mathrm{H}$ & 3.11 & 59 & -2.5 \\
\hline & 4.73 & 15 & 182 \\
\hline $\mathrm{H}$ & 3.90 & 27 & -1 . \\
\hline $\mathrm{H}$ & 4.20 & 64 & 065 \\
\hline H & 1.473037 & 24 & -1.016529 \\
\hline I & 2.03 & 89 & 0.563583 \\
\hline H & 0.55 & & 53 \\
\hline & 2.18 & & \\
\hline $\mathrm{H}$ & 46 & 93 & -1.3 \\
\hline $\mathrm{P}$ & 87 & 58 & 677 \\
\hline C & 1.066867 & 397 & -1.180275 \\
\hline & 0.346058 & -2.14938 & -0.735472 \\
\hline 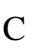 & 0.355548 & -3.21 & -1.820665 \\
\hline & -0.266291 & & \\
\hline & 0.43 & -1.4 & -3 \\
\hline C & 0.43 & -0.3 & -2.4 \\
\hline $\mathrm{H}$ & -0.602247 & -0.031244 & -2.262471 \\
\hline I & 0.962338 & 0.551732 & -2.836878 \\
\hline $\mathrm{H}$ & -0.040652 & -1.013006 & -4.47424 \\
\hline & & & 237 \\
\hline & -0.24 & -3.4 & -3.897785 \\
\hline 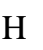 & -1.336075 & -2.4 & -2.927289 \\
\hline $\mathrm{H}$ & -0.175855 & -4.110298 & -1.469415 \\
\hline 11 & 1.395175 & -3.529614 & -2.02161 \\
\hline $\mathrm{H}$ & -0.698316 & -1.893179 & -0.481052 \\
\hline & 0.762788 & & \\
\hline & 2.127676 & & -1.379605 \\
\hline 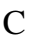 & 2.0006 & -0.031742 & 1.596778 \\
\hline$C$ & 3.134988 & -0.875265 & 1.669264 \\
\hline
\end{tabular}




\begin{tabular}{|c|c|c|c|}
\hline $\mathrm{C}$ & 3.812832 & -0.98597 & 2.894755 \\
\hline $\mathrm{C}$ & 3.410283 & -0.287236 & 4.027092 \\
\hline $\mathrm{C}$ & 2.285538 & 0.530159 & 3.962606 \\
\hline $\mathrm{C}$ & 1.589328 & 0.636686 & 2.765645 \\
\hline $\mathrm{H}$ & 0.677074 & 1.240159 & 2.727315 \\
\hline $\mathrm{H}$ & 1.933627 & 1.065827 & 4.846722 \\
\hline $\mathrm{H}$ & 3.96516 & -0.397296 & 4.961853 \\
\hline $\mathrm{H}$ & 4.681803 & -1.648021 & 2.94482 \\
\hline $\mathrm{C}$ & 3.659837 & -1.726856 & 0.562557 \\
\hline $\mathrm{C}$ & 3.27405 & -3.072902 & 0.490636 \\
\hline $\mathrm{C}$ & 3.772473 & -3.907938 & -0.507177 \\
\hline $\mathrm{C}$ & 4.67974 & -3.415467 & -1.44468 \\
\hline $\mathrm{C}$ & 5.106011 & -2.091095 & -1.357112 \\
\hline $\mathrm{C}$ & 4.607939 & -1.257552 & -0.356481 \\
\hline $\mathrm{H}$ & 4.968516 & -0.230022 & -0.279728 \\
\hline $\mathrm{H}$ & 5.841467 & -1.704129 & -2.066892 \\
\hline $\mathrm{H}$ & 5.069007 & -4.068353 & -2.229516 \\
\hline $\mathrm{H}$ & 3.449605 & -4.951061 & -0.551001 \\
\hline $\mathrm{H}$ & 2.570193 & -3.463802 & 1.230403 \\
\hline $\mathrm{Pd}$ & -1.38094 & 0.621028 & 0.601527 \\
\hline $\mathrm{Cl}$ & -1.3307 & -1.084771 & 2.282532 \\
\hline \multicolumn{4}{|c|}{$\mathrm{R}=\mathrm{Ph}(\mathbf{T S 4 b})$} \\
\hline Atom & $\mathrm{x}$ & $\mathrm{y}$ & $\mathrm{z}$ \\
\hline $\mathrm{Pd}$ & 1.23416 & -0.249155 & -0.404377 \\
\hline $\mathrm{C}$ & 3.422334 & 0.08168 & -0.764318 \\
\hline $\mathrm{C}$ & 4.206633 & -0.986194 & -0.083198 \\
\hline $\mathrm{C}$ & 4.314987 & -1.027722 & 1.318845 \\
\hline $\mathrm{C}$ & 5.041265 & -2.034309 & 1.946368 \\
\hline $\mathrm{C}$ & 5.684765 & -3.01945 & 1.195874 \\
\hline $\mathrm{C}$ & 5.596965 & -2.985335 & -0.194096 \\
\hline $\mathrm{C}$ & 4.868333 & -1.978898 & -0.824988 \\
\hline $\mathrm{H}$ & 4.838054 & -1.951161 & -1.917364 \\
\hline $\mathrm{H}$ & 6.10863 & -3.740553 & -0.79586 \\
\hline $\mathrm{H}$ & 6.255659 & -3.807396 & 1.693126 \\
\hline $\mathrm{H}$ & 5.097678 & -2.05346 & 3.037477 \\
\hline $\mathrm{H}$ & 3.78314 & -0.279483 & 1.911161 \\
\hline $\mathrm{C}$ & 2.758852 & -0.235534 & -1.983192 \\
\hline $\mathrm{H}$ & 2.598836 & 0.557369 & -2.720436 \\
\hline $\mathrm{H}$ & 2.948592 & -1.213854 & -2.432156 \\
\hline $\mathrm{C}$ & 3.670205 & 1.507239 & -0.424975 \\
\hline $\mathrm{C}$ & 4.787465 & 1.897963 & 0.330402 \\
\hline $\mathrm{C}$ & 5.026517 & 3.239487 & 0.62214 \\
\hline $\mathrm{C}$ & 4.156758 & 4.228048 & 0.17076 \\
\hline $\mathrm{C}$ & 3.044137 & 3.859854 & -0.588786 \\
\hline $\mathrm{C}$ & 2.808415 & 2.523439 & -0.883916 \\
\hline
\end{tabular}




\begin{tabular}{|c|c|c|c|}
\hline & 1.917199 & 368 & 122 \\
\hline & 2.348781 & 4.622784 & -0.948409 \\
\hline & .340322 & .278492 & 407553 \\
\hline & 5.906036 & .511173 & 210852 \\
\hline & 5.490804 & .142092 & 584282 \\
\hline & 1.133913 & -0.654683 & 92484 \\
\hline & -1.097017 & -0.425905 & -0.316012 \\
\hline c & 1.773948 & -1.572595 & 1029 \\
\hline & .191761 & -2.980711 & -1.494696 \\
\hline $\mathrm{C}$ & -1.657064 & -3.861912 & -2.645924 \\
\hline$C$ & .175442 & -3.9 & \\
\hline C & -3.766391 & -2.511221 & -2.830943 \\
\hline C & -3.296115 & -1.629375 & -1.681384 \\
\hline H & 904 & -0.6 & 023 \\
\hline & -3.669865 & -2.0 & -0.7 \\
\hline & 249 & -2.0 & 718 \\
\hline 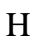 & -4.8 & -2.5 & \\
\hline & 758 & & \\
\hline & 5952 & 251 & 6615 \\
\hline & & & 499 \\
\hline & -1.2 & -4.8 & 249 \\
\hline & -0.09 & -2.9 & 418 \\
\hline H & -1.5 & -3.4 & \\
\hline & -1.3 & -1.1 & 338 \\
\hline & -1.7 & & 3142 \\
\hline & -1.1 & 477 & 0.15665 \\
\hline & -1.606125 & & 767 \\
\hline & -1.4 & 4.0 & 294 \\
\hline & -2.0 & 2.9 & 928 \\
\hline C & -1.6 & & 225 \\
\hline & -0.5 & & 8359 \\
\hline & -2.143243 & 0.84 & -2.835361 \\
\hline & -1.932673 & 3.1 & -3.583051 \\
\hline & & & \\
\hline & -1.7 & 5.0 & 955 \\
\hline & -0.3 & 5 & -1.8 \\
\hline & -1.080229 & 4.4 & 994 \\
\hline & -2.678313 & 3.793896 & 0.086842 \\
\hline & -0.02512 & 2.249458 & -0.010393 \\
\hline & & & \\
\hline & -2.8 & 1.2 & -0.5 \\
\hline & -1.74 & -1.1 & 1.26005 \\
\hline C & -2.918655 & -0.794954 & 1.971941 \\
\hline 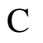 & -3.231096 & -1.532936 & 3.125431 \\
\hline C & -2.421067 & -2.568495 & 3.57716 \\
\hline & -1.2 & -2.877858 & 939 \\
\hline & -0.918481 & -2.147671 & 1.752534 \\
\hline & 0.023952 & -2.357912 & 1.237139 \\
\hline & -0.588609 & -3.66916 & 3.237693 \\
\hline & -2.695061 & -3.121832 & 4.478498 \\
\hline 11 & -4.138191 & -1.270574 & 3.676981 \\
\hline
\end{tabular}




\begin{tabular}{cccc}
$\mathrm{C}$ & -3.847049 & 0.316169 & 1.622276 \\
$\mathrm{C}$ & -3.656575 & 1.585729 & 2.185341 \\
$\mathrm{C}$ & -4.519225 & 2.636945 & 1.879697 \\
$\mathrm{C}$ & -5.592593 & 2.434887 & 1.013015 \\
$\mathrm{C}$ & -5.816519 & 1.166109 & 0.480075 \\
$\mathrm{C}$ & -4.957157 & 0.113433 & 0.791912 \\
$\mathrm{H}$ & -5.15107 & -0.882739 & 0.38816 \\
$\mathrm{H}$ & -6.671727 & 0.990924 & -0.177384 \\
$\mathrm{H}$ & -6.264963 & 3.260581 & 0.768272 \\
$\mathrm{H}$ & -4.349516 & 3.622012 & 2.321548 \\
$\mathrm{H}$ & -2.816294 & 1.744272 & 2.866904 \\
$\mathrm{Cl}$ & 1.264021 & 0.389255 & 1.937811 \\
\hline
\end{tabular}<smiles>[R]C(=CC([3H])(Cl)[PH]([2H])([3H])[3H])c1ccccc1</smiles>

\begin{tabular}{cccc}
\hline Atom & $\mathrm{x}$ & $\mathrm{y}$ & $\mathrm{z}$ \\
\hline $\mathrm{C}$ & -3.599784 & -0.262935 & -0.943964 \\
$\mathrm{C}$ & -3.560732 & 1.154447 & -0.493307 \\
$\mathrm{C}$ & -3.305212 & 1.4553 & 0.857792 \\
$\mathrm{C}$ & -3.182009 & 2.776828 & 1.276498 \\
$\mathrm{C}$ & -3.32375 & 3.82302 & 0.362728 \\
$\mathrm{C}$ & -3.592554 & 3.536723 & -0.975258 \\
$\mathrm{C}$ & -3.709353 & 2.214881 & -1.399397 \\
$\mathrm{H}$ & -3.929746 & 1.996698 & -2.447698 \\
$\mathrm{H}$ & -3.718539 & 4.349016 & -1.695325 \\
$\mathrm{H}$ & -3.229649 & 4.859986 & 0.694375 \\
$\mathrm{H}$ & -2.968416 & 2.992456 & 2.326756 \\
$\mathrm{H}$ & -3.161931 & 0.62948 & 1.562979 \\
$\mathrm{C}$ & -3.05046 & -0.605548 & -2.159565 \\
$\mathrm{H}$ & -2.735756 & 0.154919 & -2.872716 \\
$\mathrm{H}$ & -3.155622 & -1.619836 & -2.550515 \\
$\mathrm{C}$ & -4.345653 & -1.253788 & -0.139224 \\
$\mathrm{C}$ & -5.420546 & -0.844671 & 0.665059 \\
$\mathrm{C}$ & -6.195252 & -1.777371 & 1.351955 \\
$\mathrm{C}$ & -5.906627 & -3.135757 & 1.253088 \\
$\mathrm{C}$ & -4.835724 & -3.556523 & 0.461987 \\
$\mathrm{C}$ & -4.063494 & -2.628089 & -0.221992 \\
$\mathrm{H}$ & -3.197551 & -2.961792 & -0.797594 \\
$\mathrm{H}$ & -4.587808 & -4.618252 & 0.395874 \\
$\mathrm{H}$ & -6.508676 & -3.867357 & 1.797234 \\
$\mathrm{H}$ & -7.032183 & -1.436931 & 1.966196 \\
$\mathrm{H}$ & -5.668338 & 0.217021 & 0.736118 \\
$\mathrm{H}$ & -0.756117 & 0.463562 & -2.060853 \\
$\mathrm{C}$ & 1.445921 & 1.857679 & -1.022811 \\
$\mathrm{C}$ & 0.450069 & 2.934526 & -0.589767 \\
$\mathrm{C}$ & 0.727437 & 4.249354 & -1.303578 \\
$\mathrm{C}$ & 2.161377 & 4.709792 & -1.084669 \\
$\mathrm{C}$ & 3.158575 & 3.634076 & -1.489575 \\
\hline & & & \\
& & &
\end{tabular}




\begin{tabular}{|c|c|c|c|}
\hline C & 2.87944 & 2.315605 & -0.778928 \\
\hline & 3.600833 & 1.544057 & -1.097858 \\
\hline & 3.028654 & 2.446943 & .309029 \\
\hline & 3.101861 & 3.472747 & -2.581556 \\
\hline & 4.190156 & 3.962874 & -1.28798 \\
\hline & 2.359398 & 5.64493 & -1.631492 \\
\hline & 2.304481 & 4.949054 & -0.015361 \\
\hline & 0.542857 & 4.120897 & -2.385698 \\
\hline & 0.014931 & 5.018508 & -0.966265 \\
\hline & -0.583161 & 2.593803 & -0.775709 \\
\hline $\mathrm{H}$ & 0.529797 & 3.090983 & 0.501878 \\
\hline & 1.299561 & 1.699175 & -2.108 \\
\hline$P$ & 1.029305 & 0.198609 & -0.310172 \\
\hline $\mathrm{C}$ & 2.176587 & -1.020267 & -1.087928 \\
\hline & 1.718001 & -2.439853 & -0.740693 \\
\hline C & 2.6105 & 75 & -1.37935 \\
\hline C & 2.694722 & 3053 & -2.885682 \\
\hline $\mathrm{C}$ & 3.149034 & 4285 & -3.233367 \\
\hline C & 2.252563 & 4951 & -2.605001 \\
\hline H & 1.233287 & 8532 & -3.030692 \\
\hline & 2.631598 & 532 & -2.860522 \\
\hline & 3.188084 & 469 & 4683 \\
\hline & 4.18 & 58 & 613 \\
\hline & 3.36 & -4. & \\
\hline & 1.700595 & 4686 & -3.332511 \\
\hline & 2.240718 & -4.49741 & -1.130147 \\
\hline & 3.624957 & -3.4 & 842 \\
\hline & 0.676807 & 371 & 2573 \\
\hline $\mathrm{H}$ & 165 & -2 & 187 \\
\hline & 3.18 & -0.8 & -0.6 \\
\hline & 1.35 & & 1.489545 \\
\hline & 2.535925 & 0.165405 & 2.218773 \\
\hline & 2.586619 & 0.539772 & 3.572022 \\
\hline & 1.513386 & 1.154292 & 4.206349 \\
\hline & 0.34 & 23 & 311 \\
\hline $\mathrm{C}$ & 026 & 78 & 553 \\
\hline & -0.663774 & 1.173215 & 605985 \\
\hline & -0.521454 & 1.85395 & 3.976954 \\
\hline & 1.58813 & 1.430073 & 5.260821 \\
\hline & 3.501963 & 0.327832 & 4.131448 \\
\hline C & 3.74 & -0.525916 & 1.685331 \\
\hline C & 3.843263 & -1.920724 & 1.77975 \\
\hline $\mathrm{C}$ & 4.971468 & -2.586661 & 1.304702 \\
\hline $\mathrm{C}$ & 6.022201 & -1.868783 & 0.734297 \\
\hline C & 5.950006 & -0.477797 & 0.671108 \\
\hline C & 4.824243 & 0.18 & 1.153251 \\
\hline & 4.7812 & & 1.116994 \\
\hline & 6.779951 & 0.095385 & 0.25056 \\
\hline $\mathrm{H}$ & 6.903933 & -2.391483 & 0.356136 \\
\hline 11 & 5.028562 & -3.675382 & 1.379734 \\
\hline $\mathrm{H}$ & 3.021123 & -2.483633 & 2.23004 \\
\hline
\end{tabular}




\begin{tabular}{|c|c|c|c|}
\hline \multirow{2}{*}{$\begin{array}{l}\mathrm{Pd} \\
\mathrm{Cl}\end{array}$} & -1.120994 & -0.358025 & -0.773193 \\
\hline & -1.379062 & -1.696996 & 1.246405 \\
\hline \multicolumn{4}{|c|}{$\square^{\ddagger}$} \\
\hline A & \multicolumn{3}{|c|}{$\mathrm{Ar}=4-\mathrm{CN}-\mathrm{Ph}(\mathrm{TS} 1 \mathrm{c})$} \\
\hline Atom & $x$ & $\mathrm{y}$ & $\mathrm{Z}$ \\
\hline $\mathrm{C}$ & 0.497112 & 1.557135 & -1.554097 \\
\hline $\mathrm{C}$ & 0.141213 & 2.951847 & -2.069971 \\
\hline $\mathrm{C}$ & 0.951338 & 3.282072 & -3.318892 \\
\hline $\mathrm{C}$ & 2.447762 & 3.146262 & -3.079887 \\
\hline $\mathrm{C}$ & 2.802065 & 1.760608 & -2.56175 \\
\hline $\mathrm{C}$ & 2.002773 & 1.420127 & -1.313846 \\
\hline $\mathrm{H}$ & 2.235071 & 0.400124 & -0.966261 \\
\hline $\mathrm{H}$ & 2.309637 & 2.098351 & -0.495278 \\
\hline $\mathrm{H}$ & 2.587883 & 1.009498 & -3.343833 \\
\hline $\mathrm{H}$ & 3.880477 & 1.682495 & -2.35609 \\
\hline $\mathrm{H}$ & 3.008638 & 3.373683 & -3.99956 \\
\hline $\mathrm{H}$ & 2.767197 & 3.902233 & -2.339177 \\
\hline $\mathrm{H}$ & 0.649537 & 2.59731 & -4.132253 \\
\hline $\mathrm{H}$ & 0.702109 & 4.294814 & -3.672668 \\
\hline $\mathrm{H}$ & -0.936052 & 3.021389 & -2.287647 \\
\hline $\mathrm{H}$ & 0.346097 & 3.711154 & -1.294463 \\
\hline $\mathrm{H}$ & 0.239208 & 0.846745 & -2.365077 \\
\hline $\mathrm{P}$ & -0.425185 & 0.834556 & -0.104955 \\
\hline $\mathrm{Pd}$ & -0.317623 & -1.4877 & 0.003824 \\
\hline $\mathrm{C}$ & 1.524784 & -2.292428 & 0.806964 \\
\hline $\mathrm{C}$ & 2.293158 & -1.45297 & 1.65186 \\
\hline $\mathrm{C}$ & 3.504514 & -0.968684 & 1.202055 \\
\hline $\mathrm{C}$ & 4.022739 & -1.355486 & -0.057414 \\
\hline $\mathrm{C}$ & 3.300673 & -2.28055 & -0.838568 \\
\hline $\mathrm{C}$ & 2.088351 & -2.78592 & -0.398466 \\
\hline $\mathrm{H}$ & 1.553798 & -3.545525 & -0.972589 \\
\hline $\mathrm{H}$ & 3.713539 & -2.614343 & -1.792912 \\
\hline $\mathrm{C}$ & 5.250545 & -0.816411 & -0.526037 \\
\hline $\mathrm{N}$ & 6.24759 & -0.351849 & -0.920516 \\
\hline $\mathrm{H}$ & 4.074997 & -0.273981 & 1.823429 \\
\hline $\mathrm{H}$ & 1.895939 & -1.162489 & 2.626645 \\
\hline $\mathrm{Cl}$ & 0.28229 & -3.409468 & 1.605476 \\
\hline $\mathrm{C}$ & -2.17458 & 1.382337 & -0.299069 \\
\hline $\mathrm{C}$ & -3.218275 & 0.439478 & -0.500911 \\
\hline $\mathrm{C}$ & -2.99512 & -1.006213 & -0.732477 \\
\hline $\mathrm{C}$ & -2.075981 & -1.462319 & -1.707782 \\
\hline $\mathrm{C}$ & -1.901012 & -2.838718 & -1.927348 \\
\hline $\mathrm{C}$ & -2.640067 & -3.768619 & -1.194127 \\
\hline $\mathrm{C}$ & -3.565339 & -3.32645 & -0.248675 \\
\hline $\mathrm{C}$ & -3.740278 & -1.961421 & -0.023758 \\
\hline $\mathrm{H}$ & -4.447766 & -1.620688 & 0.737056 \\
\hline $\mathrm{H}$ & -4.150076 & -4.049006 & 0.324658 \\
\hline $\mathrm{H}$ & -2.49799 & -4.837535 & -1.367645 \\
\hline
\end{tabular}




\begin{tabular}{cccc}
$\mathrm{H}$ & -1.208462 & -3.173263 & -2.70384 \\
$\mathrm{H}$ & -1.601355 & -0.739081 & -2.376912 \\
$\mathrm{C}$ & -4.548709 & 0.891882 & -0.491203 \\
$\mathrm{C}$ & -4.866036 & 2.232853 & -0.315401 \\
$\mathrm{C}$ & -3.844114 & 3.165347 & -0.149954 \\
$\mathrm{C}$ & -2.520792 & 2.736121 & -0.142335 \\
$\mathrm{H}$ & -1.730278 & 3.477377 & -0.014254 \\
$\mathrm{H}$ & -4.074379 & 4.226329 & -0.02861 \\
$\mathrm{H}$ & -5.910936 & 2.55134 & -0.323045 \\
$\mathrm{H}$ & -5.347403 & 0.16332 & -0.653812 \\
$\mathrm{C}$ & 0.256253 & 1.638426 & 1.429959 \\
$\mathrm{C}$ & 0.4459 & 3.150326 & 1.545457 \\
$\mathrm{C}$ & 1.205429 & 3.500335 & 2.820441 \\
$\mathrm{C}$ & 0.49412 & 2.964259 & 4.052749 \\
$\mathrm{C}$ & 0.266667 & 1.464284 & 3.946286 \\
$\mathrm{C}$ & -0.464041 & 1.089668 & 2.664188 \\
$\mathrm{H}$ & -1.494698 & 1.490867 & 2.689949 \\
$\mathrm{H}$ & -0.569148 & -0.006768 & 2.57993 \\
$\mathrm{H}$ & -0.285044 & 1.089175 & 4.82234 \\
$\mathrm{H}$ & 1.245197 & 0.949775 & 3.964085 \\
$\mathrm{H}$ & 1.060183 & 3.207285 & 4.965353 \\
$\mathrm{H}$ & -0.480994 & 3.473693 & 4.157834 \\
$\mathrm{H}$ & 1.343401 & 4.59044 & 2.892113 \\
$\mathrm{H}$ & 2.222404 & 3.070204 & 2.764968 \\
$\mathrm{H}$ & -0.536106 & 3.652077 & 1.578518 \\
$\mathrm{H}$ & 0.975128 & 3.552923 & 0.668046 \\
$\mathrm{H}$ & 1.270301 & 1.186784 & 1.431999 \\
\hline & & & \\
\hline
\end{tabular}

$\mathrm{L}-\mathrm{Pd}-\mathrm{Cl}$
I
$\mathrm{Ar}$

\begin{tabular}{cccc}
\hline Atom & $\mathrm{x}$ & $\mathrm{y}$ & $\mathrm{z}$ \\
\hline $\mathrm{C}$ & 1.113795 & 1.869287 & -0.097674 \\
$\mathrm{C}$ & 1.81096 & 1.985624 & -1.455371 \\
$\mathrm{C}$ & 3.163439 & 2.667252 & -1.300739 \\
$\mathrm{C}$ & 3.027734 & 4.023695 & -0.625044 \\
$\mathrm{C}$ & 2.325927 & 3.903206 & 0.71874 \\
$\mathrm{C}$ & 0.964344 & 3.228609 & 0.59127 \\
$\mathrm{H}$ & 0.512463 & 3.117026 & 1.589158 \\
$\mathrm{H}$ & 0.283023 & 3.888565 & 0.028338 \\
$\mathrm{H}$ & 2.956803 & 3.309178 & 1.404338 \\
$\mathrm{H}$ & 2.212821 & 4.890749 & 1.192048 \\
$\mathrm{H}$ & 4.013999 & 4.496444 & -0.502556 \\
$\mathrm{H}$ & 2.447999 & 4.701151 & -1.278739 \\
$\mathrm{H}$ & 3.824502 & 2.019159 & -0.697089 \\
$\mathrm{H}$ & 3.651819 & 2.765614 & -2.282242 \\
$\mathrm{H}$ & 1.924007 & 0.987126 & -1.906173 \\
$\mathrm{H}$ & 1.192611 & 2.563914 & -2.162569 \\
$\mathrm{H}$ & 1.803581 & 1.283156 & 0.541468 \\
$\mathrm{P}$ & -0.322211 & 0.695726 & -0.086863 \\
$\mathrm{Pd}$ & 0.19429 & -1.438645 & -0.718552 \\
\hline
\end{tabular}




\begin{tabular}{|c|c|c|c|}
\hline & 92 & 95 & 42 \\
\hline $\mathrm{C}$ & 2.454884 & -1.140131 & 1.187552 \\
\hline & .793543 & -1.035947 & .555841 \\
\hline & .797938 & -1.03089 & 0.57419 \\
\hline & .434271 & -1.155611 & -0.778131 \\
\hline & .096498 & -1.269011 & -1.139001 \\
\hline$\Pi$ & 2.836411 & -1.389773 & -2.192746 \\
\hline $\mathrm{H}$ & 5.212319 & -1.172283 & -1.54461 \\
\hline $\mathrm{C}$ & .169364 & -0.89934 & 0.946108 \\
\hline r & .288963 & -0.780631 & 1.25095 \\
\hline & 4.069096 & -0.95 & 2.609918 \\
\hline $\mathrm{H}$ & 05 & -1.1 & 522 \\
\hline $\mathrm{Cl}$ & 0.618688 & -3.6 & \\
\hline $\mathrm{C}$ & -1.68025 & 1.398605 & 4854 \\
\hline $\mathrm{C}$ & -2.909621 & 0.711248 & -1.278568 \\
\hline $\mathrm{C}$ & -3.169104 & -0.628156 & 05177 \\
\hline C & -2.382323 & -1.7 & 205 \\
\hline $\mathrm{C}$ & -2.630228 & -2.9 & 464 \\
\hline $\mathrm{C}$ & -3.68 & -3.1 & \\
\hline $\mathrm{C}$ & -4.49703 & -2.0 & \\
\hline C & -4.249031 & -0.8 & \\
\hline $\mathrm{H}$ & -4.880914 & 0.03 & 0.4 \\
\hline $\mathrm{H}$ & -5.32 & -2.19 & 028 \\
\hline $\mathrm{H}$ & -3.87 & -4.1 & 39 \\
\hline $\mathrm{H}$ & -1.9 & -3 . & 703 \\
\hline $\mathrm{H}$ & -1.6 & -1.6 & \\
\hline $\mathrm{C}$ & -3.948784 & & 6576 \\
\hline $\mathrm{C}$ & -3.789511 & 2.58 & -2.565581 \\
\hline $\mathrm{C}$ & -2.573995 & 3.25 & 054 \\
\hline C & -1.5 & 2.66 & 756 \\
\hline $\mathrm{H}$ & -0.60 & 38 & 231 \\
\hline $\mathrm{H}$ & -2.42 & 4.23 & 487 \\
\hline $\mathrm{H}$ & -4.61 & 3.04 & -3.124755 \\
\hline I & -4.893936 & 0.79 & -2.099396 \\
\hline 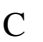 & -0.911762 & 0.78 & 1.68601 \\
\hline 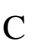 & -2.022149 & 1.80 & 1.91854 \\
\hline $\mathrm{C}$ & -2.37 & 1.91 & 13 \\
\hline$C$ & -2.7 & 0.56 & 47 \\
\hline $\mathrm{C}$ & -1.643438 & -0.455978 & 3.752214 \\
\hline $\mathrm{C}$ & -1.282575 & -0.579638 & 2.278854 \\
\hline $\mathrm{H}$ & -2.137715 & -1.003316 & 1.728805 \\
\hline & -0.46208 & -1.30 & 2.134052 \\
\hline & -1.93 & -1.4 & 4.1 \\
\hline $\mathrm{H}$ & -0.747852 & -0.15 & 4.324877 \\
\hline $\mathrm{H}$ & -2.990075 & 0.651392 & 5.044306 \\
\hline $\mathrm{H}$ & -3.674245 & 0.206164 & 3.482569 \\
\hline & -3.18 & 2.64 & 3.535964 \\
\hline & 65 & 2.325031 & 788 \\
\hline & -2.920636 & 1.495886 & 1.356866 \\
\hline 11 & -1.745817 & 2.792363 & 1.505202 \\
\hline 11 & -0.00505 & 1.130693 & 2.221474 \\
\hline
\end{tabular}




\begin{tabular}{|c|c|c|c|}
\hline $\mathrm{R}^{\prime}$ & \multicolumn{3}{|c|}{$\mathrm{R}=\mathrm{CO}_{2} \mathrm{Me}, \mathrm{R}^{\prime}=\mathrm{CN}(\mathbf{I 5 c})$} \\
\hline Atom & $\mathrm{x}$ & $\mathrm{y}$ & $\mathrm{z}$ \\
\hline $\mathrm{Pd}$ & -1.468704 & -0.51347 & 0.601895 \\
\hline $\mathrm{P}$ & 0.704376 & 0.254443 & 0.16195 \\
\hline $\mathrm{C}$ & 0.729725 & 2.044599 & -0.323608 \\
\hline $\mathrm{C}$ & 0.013948 & 2.921854 & 0.704418 \\
\hline $\mathrm{C}$ & -0.047632 & 4.371763 & 0.244263 \\
\hline $\mathrm{C}$ & 1.336738 & 4.916969 & -0.072073 \\
\hline $\mathrm{C}$ & 2.048236 & 4.045726 & -1.095873 \\
\hline $\mathrm{C}$ & 2.118471 & 2.595272 & -0.636266 \\
\hline $\mathrm{H}$ & 2.630041 & 1.971251 & -1.388662 \\
\hline $\mathrm{H}$ & 2.732594 & 2.532185 & 0.28129 \\
\hline $\mathrm{H}$ & 1.506611 & 4.094615 & -2.057928 \\
\hline $\mathrm{H}$ & 3.060877 & 4.427459 & -1.299699 \\
\hline $\mathrm{H}$ & 1.269 & 5.955656 & -0.429399 \\
\hline $\mathrm{H}$ & 1.938843 & 4.952962 & 0.854058 \\
\hline $\mathrm{H}$ & -0.677138 & 4.448154 & -0.658762 \\
\hline $\mathrm{H}$ & -0.544787 & 4.98886 & 1.008746 \\
\hline $\mathrm{H}$ & -0.997547 & 2.523114 & 0.904691 \\
\hline $\mathrm{H}$ & 0.557353 & 2.872052 & 1.665305 \\
\hline $\mathrm{H}$ & 0.11972 & 2.067102 & -1.247621 \\
\hline $\mathrm{C}$ & 1.394239 & -0.687268 & -1.278285 \\
\hline $\mathrm{C}$ & 1.083132 & -2.179065 & -1.106471 \\
\hline $\mathrm{C}$ & 1.581528 & -2.999349 & -2.285203 \\
\hline $\mathrm{C}$ & 1.022492 & -2.479794 & -3.600324 \\
\hline $\mathrm{C}$ & 1.334625 & -1.003132 & -3.775515 \\
\hline $\mathrm{C}$ & 0.82176 & -0.17679 & -2.603941 \\
\hline $\mathrm{H}$ & -0.282936 & -0.233021 & -2.568514 \\
\hline $\mathrm{H}$ & 1.073668 & 0.883533 & -2.764027 \\
\hline $\mathrm{H}$ & 0.913606 & -0.620073 & -4.718161 \\
\hline $\mathrm{H}$ & 2.428873 & -0.867795 & -3.854526 \\
\hline $\mathrm{H}$ & 1.41187 & -3.062401 & -4.449564 \\
\hline $\mathrm{H}$ & -0.074086 & -2.619835 & -3.614112 \\
\hline $\mathrm{H}$ & 1.321467 & -4.059707 & -2.13975 \\
\hline $\mathrm{H}$ & 2.685292 & -2.958243 & -2.318764 \\
\hline $\mathrm{H}$ & -0.013333 & -2.298418 & -1.00695 \\
\hline $\mathrm{H}$ & 1.492784 & -2.557284 & -0.156907 \\
\hline $\mathrm{H}$ & 2.487197 & -0.548363 & -1.315103 \\
\hline $\mathrm{C}$ & 1.790781 & 0.199188 & 1.643733 \\
\hline $\mathrm{C}$ & 3.17485 & -0.072473 & 1.72701 \\
\hline $\mathrm{C}$ & 3.816476 & 0.068324 & 2.96786 \\
\hline $\mathrm{C}$ & 3.127909 & 0.463082 & 4.109476 \\
\hline $\mathrm{C}$ & 1.759682 & 0.70901 & 4.03446 \\
\hline $\mathrm{C}$ & 1.106593 & 0.565944 & 2.817251 \\
\hline
\end{tabular}




\begin{tabular}{cccc}
$\mathrm{H}$ & 0.025037 & 0.722178 & 2.766346 \\
$\mathrm{H}$ & 1.194148 & 0.992726 & 4.924234 \\
$\mathrm{H}$ & 3.658083 & 0.561194 & 5.059619 \\
$\mathrm{H}$ & 4.886196 & -0.150729 & 3.024383 \\
$\mathrm{C}$ & 4.008803 & -0.561034 & 0.594838 \\
$\mathrm{C}$ & 4.106729 & -1.937802 & 0.351495 \\
$\mathrm{C}$ & 4.884383 & -2.420276 & -0.699408 \\
$\mathrm{C}$ & 5.581679 & -1.534208 & -1.520076 \\
$\mathrm{C}$ & 5.521217 & -0.164891 & -1.263507 \\
$\mathrm{C}$ & 4.749301 & 0.317149 & -0.207096 \\
$\mathrm{H}$ & 4.716285 & 1.389899 & -0.001843 \\
$\mathrm{H}$ & 6.085987 & 0.533968 & -1.88537 \\
$\mathrm{H}$ & 6.187728 & -1.911485 & -2.347104 \\
$\mathrm{H}$ & 4.944795 & -3.496784 & -0.877966 \\
$\mathrm{H}$ & 3.559493 & -2.631459 & 0.995878 \\
$\mathrm{Cl}$ & -0.728159 & -2.135668 & 2.169877 \\
$\mathrm{C}$ & -3.519437 & 0.106517 & 0.072331 \\
$\mathrm{C}$ & -2.74997 & 0.21983 & -1.142239 \\
$\mathrm{C}$ & -2.576644 & 1.472849 & -1.763627 \\
$\mathrm{C}$ & -3.125204 & 2.626913 & -1.219408 \\
$\mathrm{C}$ & -3.868222 & 2.534515 & -0.009618 \\
$\mathrm{C}$ & -4.040625 & 1.327085 & 0.618471 \\
$\mathrm{H}$ & -4.626671 & 1.285711 & 1.537162 \\
$\mathrm{H}$ & -4.30717 & 3.44004 & 0.413797 \\
$\mathrm{C}$ & -2.963233 & 3.88154 & -1.87632 \\
$\mathrm{~N}$ & -2.823898 & 4.906987 & -2.414971 \\
$\mathrm{H}$ & -2.029041 & 1.529878 & -2.707883 \\
$\mathrm{H}$ & -2.512039 & -0.677408 & -1.714181 \\
$\mathrm{C}$ & -3.556601 & -1.132995 & 0.819065 \\
$\mathrm{C}$ & -3.59793 & -2.493375 & 0.21366 \\
$\mathrm{O}$ & -2.972012 & -2.60854 & -0.985891 \\
$\mathrm{C}$ & -2.906949 & -3.931536 & -1.497833 \\
$\mathrm{H}$ & -2.36771 & -4.588248 & -0.801258 \\
$\mathrm{H}$ & -3.910594 & -4.347312 & -1.657797 \\
$\mathrm{H}$ & -2.369733 & -3.869304 & -2.449694 \\
$\mathrm{O}$ & -4.114889 & -3.439147 & 0.75683 \\
$\mathrm{C}$ & -4.098003 & -1.130582 & 2.218421 \\
$\mathrm{H}$ & -3.725097 & -2.006429 & 2.760777 \\
$\mathrm{H}$ & -3.791879 & -0.238375 & 2.777847 \\
$\mathrm{H}$ & -5.198925 & -1.189289 & 2.230002 \\
\hline & & & \\
\hline & & &
\end{tabular}

\begin{tabular}{|c|c|c|c|}
\hline \multicolumn{4}{|c|}{$\left.\underset{\mathrm{A}^{\prime} r}{\mathrm{~L}-\mathrm{Pd}-\overline{\mathrm{Cl}}}\right|^{\ddagger} \quad \mathrm{Ar}=4-\mathrm{OMe}-\mathrm{Ph}(\mathrm{TS} 1 \mathrm{~d})$} \\
\hline Atom & $\mathrm{x}$ & $\mathrm{y}$ & $\mathrm{Z}$ \\
\hline $\mathrm{C}$ & 0.405664 & 1.454707 & -1.652155 \\
\hline $\mathrm{C}$ & 0.176213 & 2.877522 & -2.158423 \\
\hline $\mathrm{C}$ & 0.917651 & 3.096734 & -3.473892 \\
\hline $\mathrm{C}$ & 2.403661 & 2.787844 & -3.354701 \\
\hline $\mathrm{C}$ & 2.636553 & 1.379749 & -2.827304 \\
\hline
\end{tabular}




\begin{tabular}{|c|c|c|c|}
\hline $\mathrm{C}$ & 1.900555 & 1.16052 & -1.5161 \\
\hline & 2.045221 & 0.131919 & -1.150398 \\
\hline & 2.33729 & .82522 & -0.746306 \\
\hline & 2.280083 & 0.642121 & -3.569347 \\
\hline & 3.711629 & 1.177147 & -2.69 \\
\hline & 2.90656 & 2.932285 & -4.32385 \\
\hline & 2.869522 & 3.513576 & -2.662848 \\
\hline & 0.473194 & 2.442946 & -4.246131 \\
\hline & .762079 & 4.127593 & -3.82938 \\
\hline $\mathrm{H}$ & .898365 & 3.07626 & -2.2 \\
\hline $\mathrm{H}$ & 0.533475 & & -1. \\
\hline $\mathrm{H}$ & .020037 & $0.7^{\prime}$ & 0525 \\
\hline 1 & .476793 & 0.80 & -0.137002 \\
\hline $\mathrm{P}$ & 0.512429 & $-1.4 \mathrm{C}$ & -0.056655 \\
\hline c & 418755 & -2 & 0.3 \\
\hline$c$ & 51 & -1.9 & \\
\hline $\mathrm{C}$ & 3.34 & -1.7 & \\
\hline $\mathrm{C}$ & 3.929113 & & \\
\hline $\mathrm{C}$ & 3.2811 & -2.1 & 7306 \\
\hline $\mathrm{C}$ & 2.049157 & -2.7 & 7708 \\
\hline & 46 & -3.3 & -1 . \\
\hline $\mathrm{H}$ & 53 & -2.2 & -2 \\
\hline $\mathrm{O}$ & 2 & -0.8 & \\
\hline $\mathrm{C}$ & 37 & & \\
\hline $\mathrm{H}$ & .042951 & -0.5 & \\
\hline $\mathrm{H}$ & 618911 & & 4987 \\
\hline & 61 & 0.8 & 596 \\
\hline $\mathrm{H}$ & 31 & -0.7 & 47 \\
\hline$\Pi$ & 2 & & \\
\hline C & 6 & -3. & \\
\hline $\mathrm{C}$ & 677 & & -0. \\
\hline $\mathrm{C}$ & .327594 & 13 & -0.121051 \\
\hline $\mathrm{C}$ & .385771 & -0.5 & -0.3 \\
\hline $\mathrm{C}$ & -2.737363 & -1.1 & 7188 \\
\hline $\mathrm{C}$ & 49 & -2.5 & -1. \\
\hline $\mathrm{C}$ & -3.5 & -3. & -0 . \\
\hline $\mathrm{C}$ & -4.2 & -2.7 & 0.2 \\
\hline C & -4.126489 & -1.411564 & 0.491689 \\
\hline $\mathbf{H}$ & -4.620322 & -0.971598 & \\
\hline & -4.776918 & -3.414948 & 0.953444 \\
\hline $\mathrm{H}$ & -3.6 & -4.4 & $-1 .($ \\
\hline $\mathrm{H}$ & -2.35 & -2.9 & -2.5 \\
\hline $\mathrm{H}$ & -2.23083 & -0.524794 & -2.192468 \\
\hline $\mathrm{C}$ & -4.546883 & 1.545795 & 0.089357 \\
\hline $\mathrm{C}$ & -4.608677 & 2.921272 & 0.274405 \\
\hline $\mathrm{C}$ & -3.435206 & 3.67 & 437 \\
\hline $\mathrm{C}$ & -2.216191 & 3.027985 & \\
\hline $\mathrm{H}$ & -1.305576 & 3.628032 & 0.036752 \\
\hline $\mathrm{H}$ & -3.467016 & 4.75765 & 0.364195 \\
\hline 11 & -5.574909 & 3.409194 & 0.423487 \\
\hline $\mathrm{H}$ & -5.469338 & 0.958874 & 0.076066 \\
\hline
\end{tabular}




\begin{tabular}{cccc}
$\mathrm{C}$ & 0.4801 & 1.463223 & 1.322234 \\
$\mathrm{C}$ & 0.812661 & 2.945755 & 1.478887 \\
$\mathrm{C}$ & 1.806116 & 3.149749 & 2.617376 \\
$\mathrm{C}$ & 1.26224 & 2.598485 & 3.926582 \\
$\mathrm{C}$ & 0.862434 & 1.13679 & 3.789158 \\
$\mathrm{C}$ & -0.097193 & 0.913948 & 2.628188 \\
$\mathrm{H}$ & -1.062353 & 1.412851 & 2.837405 \\
$\mathrm{H}$ & -0.330772 & -0.159406 & 2.511805 \\
$\mathrm{H}$ & 0.421966 & 0.764685 & 4.727572 \\
$\mathrm{H}$ & 1.770181 & 0.527696 & 3.620378 \\
$\mathrm{H}$ & 1.995593 & 2.726631 & 4.738273 \\
$\mathrm{H}$ & 0.377405 & 3.189991 & 4.22379 \\
$\mathrm{H}$ & 2.058616 & 4.217174 & 2.719113 \\
$\mathrm{H}$ & 2.753328 & 2.636375 & 2.365369 \\
$\mathrm{H}$ & -0.105293 & 3.512271 & 1.712594 \\
$\mathrm{H}$ & 1.212311 & 3.369517 & 0.543953 \\
$\mathrm{H}$ & 1.43882 & 0.929512 & 1.156994 \\
\hline
\end{tabular}

\begin{tabular}{cccc}
$\begin{array}{c}\text { L-Pd}-\mathrm{Cl} \\
\mathrm{I} \\
\mathrm{Ar}\end{array}$ & $\mathrm{Ar}=4-\mathrm{OMe}-\mathrm{Ph}(\mathbf{I 2 d})$ & \\
\hline Atom & $\mathrm{x}$ & $\mathrm{y}$ & $\mathrm{z}$ \\
\hline $\mathrm{C}$ & 1.013292 & 1.884734 & -0.080831 \\
$\mathrm{C}$ & 1.732609 & 1.991933 & -1.427425 \\
$\mathrm{C}$ & 3.0816 & 2.675631 & -1.254366 \\
$\mathrm{C}$ & 2.933159 & 4.03598 & -0.589163 \\
$\mathrm{C}$ & 2.207902 & 3.923249 & 0.743042 \\
$\mathrm{C}$ & 0.848065 & 3.248289 & 0.595531 \\
$\mathrm{H}$ & 0.379162 & 3.142721 & 1.586409 \\
$\mathrm{H}$ & 0.177017 & 3.90589 & 0.017332 \\
$\mathrm{H}$ & 2.826149 & 3.331086 & 1.441877 \\
$\mathrm{H}$ & 2.088231 & 4.91372 & 1.209164 \\
$\mathrm{H}$ & 3.916479 & 4.511746 & -0.451882 \\
$\mathrm{H}$ & 2.363895 & 4.709139 & -1.256617 \\
$\mathrm{H}$ & 3.730881 & 2.029544 & -0.635887 \\
$\mathrm{H}$ & 3.586458 & 2.769263 & -2.228326 \\
$\mathrm{H}$ & 1.857106 & 0.989046 & -1.865149 \\
$\mathrm{H}$ & 1.126101 & 2.563574 & -2.150508 \\
$\mathrm{H}$ & 1.696755 & 1.307658 & 0.571877 \\
$\mathrm{P}$ & -0.406677 & 0.692334 & -0.08835 \\
$\mathrm{Pd}$ & 0.147531 & -1.4359 & -0.689057 \\
$\mathrm{C}$ & 2.033156 & -1.194519 & -0.072028 \\
$\mathrm{C}$ & 2.353873 & -1.005504 & 1.277814 \\
$\mathrm{C}$ & 3.678731 & -0.854688 & 1.680092 \\
$\mathrm{C}$ & 4.712548 & -0.89386 & 0.736244 \\
$\mathrm{C}$ & 4.399951 & -1.098799 & -0.61197 \\
$\mathrm{C}$ & 3.066854 & -1.255798 & -1.005689 \\
$\mathrm{H}$ & 2.849606 & -1.439081 & -2.060678 \\
$\mathrm{H}$ & 5.183561 & -1.154383 & -1.369929 \\
$\mathrm{O}$ & 5.97231 & -0.727012 & 1.216543 \\
$\mathrm{C}$ & 7.032481 & -0.764221 & 0.301919 \\
\hline & & &
\end{tabular}




\begin{tabular}{|c|c|c|c|}
\hline $\mathrm{H}$ & 7.954034 & -0.61506 & 0.875442 \\
\hline $\mathrm{H}$ & 7.097089 & -1.733122 & -0.222048 \\
\hline $\mathrm{H}$ & 6.955945 & 0.035166 & -0.455658 \\
\hline $\mathrm{H}$ & 3.936217 & -0.709609 & 2.73171 \\
\hline $\mathrm{H}$ & 1.570612 & -0.966937 & 2.041544 \\
\hline $\mathrm{Cl}$ & 0.593001 & -3.640899 & -1.423835 \\
\hline $\mathrm{C}$ & -1.75498 & 1.380442 & -1.142618 \\
\hline $\mathrm{C}$ & -2.975127 & 0.682083 & -1.32902 \\
\hline $\mathrm{C}$ & -3.236774 & -0.657539 & -0.756117 \\
\hline $\mathrm{C}$ & -2.437356 & -1.769328 & -1.073422 \\
\hline $\mathrm{C}$ & -2.687514 & -3.023567 & -0.513736 \\
\hline $\mathrm{C}$ & -3.754847 & -3.187004 & 0.366399 \\
\hline $\mathrm{C}$ & -4.583297 & -2.10297 & 0.660568 \\
\hline $\mathrm{C}$ & -4.331839 & -0.852588 & 0.098788 \\
\hline $\mathrm{H}$ & -4.97321 & -0.00112 & 0.346423 \\
\hline $\mathrm{H}$ & -5.42828 & -2.228477 & 1.342213 \\
\hline $\mathrm{H}$ & -3.948063 & -4.16389 & 0.814895 \\
\hline $\mathrm{H}$ & -2.024461 & -3.85174 & -0.774876 \\
\hline $\mathrm{H}$ & -1.677572 & -1.679626 & -1.871344 \\
\hline $\mathrm{C}$ & -4.005134 & 1.291812 & -2.060258 \\
\hline $\mathrm{C}$ & -3.845927 & 2.546076 & -2.640507 \\
\hline $\mathrm{C}$ & -2.639376 & 3.220342 & -2.485365 \\
\hline $\mathrm{C}$ & -1.61547 & 2.642363 & -1.739871 \\
\hline $\mathrm{H}$ & -0.690093 & 3.202114 & -1.614624 \\
\hline $\mathrm{H}$ & -2.491337 & 4.204243 & -2.935874 \\
\hline $\mathrm{H}$ & -4.66021 & 2.989414 & -3.217802 \\
\hline $\mathrm{H}$ & -4.943147 & 0.745157 & -2.189725 \\
\hline $\mathrm{C}$ & -1.038269 & 0.787772 & 1.670939 \\
\hline $\mathrm{C}$ & -2.169009 & 1.796997 & 1.872771 \\
\hline $\mathrm{C}$ & -2.554483 & 1.90942 & 3.340458 \\
\hline $\mathrm{C}$ & -2.925556 & 0.551804 & 3.917719 \\
\hline $\mathrm{C}$ & -1.799382 & -0.452713 & 3.72597 \\
\hline $\mathrm{C}$ & -1.403256 & -0.577772 & 2.261911 \\
\hline $\mathrm{H}$ & -2.23958 & -1.016407 & 1.694216 \\
\hline $\mathrm{H}$ & -0.569374 & -1.287419 & 2.138197 \\
\hline $\mathrm{H}$ & -2.084479 & -1.439679 & 4.121888 \\
\hline $\mathrm{H}$ & -0.921327 & -0.133407 & 4.317122 \\
\hline $\mathrm{H}$ & -3.190469 & 0.641424 & 4.982583 \\
\hline $\mathrm{H}$ & -3.833192 & 0.178195 & 3.408548 \\
\hline $\mathrm{H}$ & -3.381748 & 2.626435 & 3.459307 \\
\hline $\mathrm{H}$ & -1.705647 & 2.331114 & 3.909578 \\
\hline $\mathrm{H}$ & -3.049745 & 1.468006 & 1.292525 \\
\hline $\mathrm{H}$ & -1.898741 & 2.782665 & 1.460154 \\
\hline $\mathrm{H}$ & -0.15017 & 1.152035 & 2.22597 \\
\hline
\end{tabular}




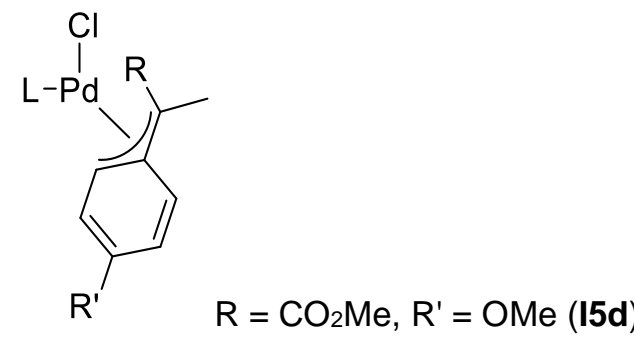

\begin{tabular}{cccc}
\hline Atom & $\mathrm{x}$ & $\mathrm{y}$ & $\mathrm{Z}$ \\
\hline $\mathrm{Pd}$ & -1.347896 & -0.726272 & 0.646464 \\
$\mathrm{P}$ & 0.718012 & 0.260893 & 0.154089 \\
$\mathrm{C}$ & 0.576087 & 2.026175 & -0.402751 \\
$\mathrm{C}$ & -0.219727 & 2.877839 & 0.585238 \\
$\mathrm{C}$ & -0.430823 & 4.283951 & 0.039692 \\
$\mathrm{C}$ & 0.892684 & 4.950856 & -0.306866 \\
$\mathrm{C}$ & 1.69837 & 4.102934 & -1.279495 \\
$\mathrm{C}$ & 1.905112 & 2.691754 & -0.745468 \\
$\mathrm{H}$ & 2.478952 & 2.083424 & -1.46507 \\
$\mathrm{H}$ & 2.519522 & 2.734751 & 0.173675 \\
$\mathrm{H}$ & 1.166293 & 4.049665 & -2.247064 \\
$\mathrm{H}$ & 2.669922 & 4.574524 & -1.496108 \\
$\mathrm{H}$ & 0.724549 & 5.958175 & -0.718789 \\
$\mathrm{H}$ & 1.479492 & 5.095914 & 0.618145 \\
$\mathrm{H}$ & -1.058471 & 4.227131 & -0.867641 \\
$\mathrm{H}$ & -0.993242 & 4.892275 & 0.766581 \\
$\mathrm{H}$ & -1.183785 & 2.389167 & 0.815078 \\
$\mathrm{H}$ & 0.327749 & 2.937706 & 1.543672 \\
$\mathrm{H}$ & -0.03863 & 1.950991 & -1.320524 \\
$\mathrm{C}$ & 1.506398 & -0.640062 & -1.265371 \\
$\mathrm{C}$ & 1.346195 & -2.149929 & -1.055234 \\
$\mathrm{C}$ & 1.938187 & -2.9486 & -2.204315 \\
$\mathrm{C}$ & 1.339706 & -2.525841 & -3.536806 \\
$\mathrm{C}$ & 1.490911 & -1.028783 & -3.751089 \\
$\mathrm{C}$ & 0.888444 & -0.227478 & -2.604665 \\
$\mathrm{H}$ & -0.205405 & -0.392734 & -2.568834 \\
$\mathrm{H}$ & 1.032237 & 0.847647 & -2.795677 \\
$\mathrm{H}$ & 1.035975 & -0.720381 & -4.705463 \\
$\mathrm{H}$ & 2.565061 & -0.779001 & -3.83178 \\
$\mathrm{H}$ & 1.797861 & -3.084192 & -4.368092 \\
$\mathrm{H}$ & 0.265131 & -2.784905 & -3.553385 \\
$\mathrm{H}$ & 1.784604 & -4.025341 & -2.030393 \\
$\mathrm{H}$ & 3.032742 & -2.797862 & -2.232092 \\
$\mathrm{H}$ & 0.265951 & -2.375475 & -0.965241 \\
$\mathrm{H}$ & 1.771866 & -2.455916 & -0.08748 \\
$\mathrm{H}$ & 2.579294 & -0.390704 & -1.30847 \\
$\mathrm{C}$ & 1.814413 & 0.38881 & 1.626553 \\
$\mathrm{C}$ & 3.221094 & 0.29037 & 1.713079 \\
$\mathrm{C}$ & 3.846129 & 0.578912 & 2.936565 \\
$\mathrm{C}$ & 3.118113 & 0.947903 & 4.062619 \\
$\mathrm{C}$ & 1.729379 & 1.013343 & 3.989054 \\
$\mathrm{C}$ & 1.094384 & 0.725225 & 2.787751
\end{tabular}




\begin{tabular}{cccc}
$\mathrm{H}$ & 0.001047 & 0.741831 & 2.738448 \\
$\mathrm{H}$ & 1.136392 & 1.269194 & 4.869542 \\
$\mathrm{H}$ & 3.635914 & 1.162733 & 5.000441 \\
$\mathrm{H}$ & 4.934757 & 0.49403 & 2.994411 \\
$\mathrm{C}$ & 4.098903 & -0.173824 & 0.604354 \\
$\mathrm{C}$ & 4.305755 & -1.548031 & 0.421043 \\
$\mathrm{C}$ & 5.12656 & -2.012123 & -0.604698 \\
$\mathrm{C}$ & 5.757263 & -1.109892 & -1.461178 \\
$\mathrm{C}$ & 5.585628 & 0.260227 & -1.265943 \\
$\mathrm{C}$ & 4.771322 & 0.724939 & -0.233774 \\
$\mathrm{H}$ & 4.64902 & 1.799887 & -0.07814 \\
$\mathrm{H}$ & 6.095263 & 0.974056 & -1.917914 \\
$\mathrm{H}$ & 6.396255 & -1.473596 & -2.269371 \\
$\mathrm{H}$ & 5.27233 & -3.087223 & -0.736319 \\
$\mathrm{H}$ & 3.80854 & -2.254068 & 1.092106 \\
$\mathrm{Cl}$ & -0.383262 & -2.289577 & 2.168416 \\
$\mathrm{C}$ & -3.441847 & -0.259355 & 0.103007 \\
$\mathrm{C}$ & -2.719973 & -0.058976 & -1.126846 \\
$\mathrm{C}$ & -2.689098 & 1.201798 & -1.749143 \\
$\mathrm{C}$ & -3.336963 & 2.291818 & -1.188624 \\
$\mathrm{C}$ & -4.03487 & 2.125967 & 0.03158 \\
$\mathrm{C}$ & -4.068172 & 0.899415 & 0.657922 \\
$\mathrm{H}$ & -4.625467 & 0.802169 & 1.590738 \\
$\mathrm{H}$ & -4.556562 & 2.967008 & 0.491138 \\
$\mathrm{O}$ & -3.272379 & 3.462113 & -1.866374 \\
$\mathrm{C}$ & -3.971616 & 4.570744 & -1.359499 \\
$\mathrm{C}$ & -1.57509 & 1.841244 & -0.458022 \\
$\mathrm{H}$ & -1.701271 & 1.998163 & -1.974451 \\
\hline $\mathrm{H}$ & -3.598229 & 4.876769 & -0.367786 \\
$\mathrm{H}$ & -3.809464 & 5.393855 & -2.063516 \\
$\mathrm{H}$ & -2.181376 & 1.33083 & -2.707798 \\
$\mathrm{H}$ & -2.38192 & -0.924981 & -1.69541 \\
$\mathrm{C}$ & -3.354383 & -1.50453 & 0.851541 \\
$\mathrm{C}$ & -3.291669 & -2.858092 & 0.237621 \\
$\mathrm{O}$ & -2.685139 & -2.907366 & -0.978705 \\
$\mathrm{H}$ & -4.987863 & -1.688592 & 2.267815 \\
\hline $\mathrm{C}$ & -2.486246 & -4.214878 & -1.490619 \\
$\mathrm{H}$ & -1.820871 & -4.789877 & -0.830693 \\
$\mathrm{H}$ & -3.435705 & -4.759347 & -1.579879 \\
$\mathrm{H}$ & -2.025863 & -4.096273 & -2.47691 \\
$\mathrm{C}$ & -3.703812 & -3.854989 & 0.781477 \\
$\mathrm{H}$ & -3.893048 & -1.554706 & 2.252097 \\
$\mathrm{H}$ & -3.647209 & -2.408061 & 2.784521 \\
$\mathrm{H}$ & & -10.648823 & 2.819798 \\
\hline
\end{tabular}




\begin{tabular}{|c|c|c|c|}
\hline 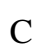 & -1.99181 & 3.440575 & 968 \\
\hline & -3.219906 & 3.974876 & -1.641423 \\
\hline & .081559 & 3.822001 & -0.134521 \\
\hline & 2.814931 & 2.373889 & 263247 \\
\hline 11 & -2.686415 & 2.306902 & 55036 \\
\hline $\mathrm{H}$ & -3.707442 & 1.770279 & 021415 \\
\hline & -2.244395 & 4.449864 & 0.219661 \\
\hline & -3.979814 & 4.197362 & 38052 \\
\hline & -3.400623 & 5.027777 & -1.90883 \\
\hline $\mathrm{H}$ & -4.112654 & 3.419261 & -1.982795 \\
\hline $\mathrm{H}$ & -1.118629 & 4.067185 & -2.104876 \\
\hline $\mathrm{H}$ & -2.11279 & 3.525294 & -3.454381 \\
\hline $\mathrm{H}$ & -0.779688 & 1.639599 & -2.465761 \\
\hline $\mathrm{H}$ & -2.512 & 1.345876 & -2.347244 \\
\hline & -0.738731 & 2.494164 & 3594 \\
\hline $\mathrm{P}$ & -0.827215 & 0.18 & 5246 \\
\hline $\mathrm{C}$ & -1.15 & & \\
\hline $\mathrm{C}$ & -2.572128 & 3102 & \\
\hline $\mathrm{C}$ & -2.714458 & -0.594008 & 3.686876 \\
\hline C & -1.707016 & 31 & 64 \\
\hline & -0.287463 & -1.2 & 3.863663 \\
\hline & -0.14 & -1.0 & 966 \\
\hline & -0.30 & -2.0 & 595 \\
\hline $\mathrm{H}$ & 0.88 & -0.7 & \\
\hline & 0.434397 & 1498 & 4.24 \\
\hline & -0.02 & 3499 & 4.344015 \\
\hline $\mathrm{H}$ & -1.800851 & 899 & 359 \\
\hline & -1.93 & 804 & 651 \\
\hline [ & -3.7 & -0.8 & 3.9 \\
\hline $\mathrm{H}$ & -2.56 & 96 & 69 \\
\hline & -2.79324 & 3949 & 1.721265 \\
\hline & -3.324945 & 0.210211 & 1.765959 \\
\hline & -0.938831 & 845 & 2.206818 \\
\hline & -1.86158 & 432 & 28414 \\
\hline c & -1.27 & -2.3 & 532 \\
\hline & -2.100449 & -3.4 & 335 \\
\hline C & -3.477665 & -3.250978 & -1.772781 \\
\hline 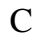 & -4.055101 & -2.027944 & -1.4412 \\
\hline $\mathrm{C}$ & -3.251196 & -0.995355 & -0.966021 \\
\hline & 2 & & \\
\hline $\mathrm{H}$ & -5.13 & 887 & -1.5 \\
\hline I & -4.097325 & -4.0 & -2.132112 \\
\hline $\mathrm{H}$ & -1.635721 & -4.361582 & -1.941772 \\
\hline C & 0.196181 & -2.5973 & -1.184436 \\
\hline 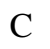 & 1.022628 & -1.786422 & -2.019505 \\
\hline $\mathrm{C}$ & 2.434 & -1.876548 & -1.917106 \\
\hline$C$ & 3.00 & -2.804276 & -1.016541 \\
\hline C & 2.192479 & -3.638974 & -0.264802 \\
\hline $\mathrm{C}$ & 0.78982 & -3.536643 & -0.349926 \\
\hline & 0.155944 & -4.160536 & 0.287569 \\
\hline H & 2.639244 & -4.372784 & 0.409991 \\
\hline
\end{tabular}




\begin{tabular}{cccc}
$\mathrm{H}$ & 4.093036 & -2.876719 & -0.937735 \\
$\mathrm{H}$ & 3.068629 & -1.360741 & -2.643845 \\
$\mathrm{H}$ & 0.558285 & -1.257647 & -2.860024 \\
$\mathrm{Pd}$ & 1.376685 & -0.083766 & -0.694041 \\
$\mathrm{C}$ & 2.91349 & 1.679053 & -0.367587 \\
$\mathrm{C}$ & 2.287642 & 2.014792 & 0.92405 \\
$\mathrm{O}$ & 2.795348 & 1.278045 & 1.939769 \\
$\mathrm{C}$ & 2.257901 & 1.561817 & 3.219531 \\
$\mathrm{H}$ & 2.693774 & 0.831487 & 3.908539 \\
$\mathrm{H}$ & 2.514257 & 2.581319 & 3.540089 \\
$\mathrm{H}$ & 1.163168 & 1.466969 & 3.220114 \\
$\mathrm{O}$ & 1.458191 & 2.888538 & 1.071599 \\
$\mathrm{C}$ & 2.717021 & 2.589831 & -1.547019 \\
$\mathrm{H}$ & 3.37355 & 3.474611 & -1.512492 \\
$\mathrm{H}$ & 2.88566 & 2.066888 & -2.497046 \\
$\mathrm{H}$ & 1.678276 & 2.941283 & -1.53124 \\
$\mathrm{~N}$ & 4.036813 & 0.969754 & -0.320419 \\
$\mathrm{~N}$ & 5.006971 & 0.366321 & -0.276531 \\
\hline
\end{tabular}

\begin{tabular}{|c|c|c|c|}
\hline \multicolumn{4}{|c|}{$\mathrm{R}=\mathrm{CO}_{2} \mathrm{Me}(\mathrm{TS}-\mathrm{S} 1 \mathrm{a})$} \\
\hline Atom & $\mathrm{x}$ & $\mathrm{y}$ & $\mathrm{z}$ \\
\hline $\mathrm{C}$ & -1.29859 & 1.992478 & -0.436288 \\
\hline $\mathrm{C}$ & -1.716453 & 2.092929 & -1.905644 \\
\hline $\mathrm{C}$ & -1.824176 & 3.542116 & -2.357924 \\
\hline $\mathrm{C}$ & -2.749493 & 4.339796 & -1.452675 \\
\hline $\mathrm{C}$ & -2.306766 & 4.24796 & -0.000993 \\
\hline $\mathrm{C}$ & -2.223374 & 2.801746 & 0.473803 \\
\hline $\mathrm{H}$ & -1.860151 & 2.773416 & 1.512481 \\
\hline $\mathrm{H}$ & -3.241575 & 2.373207 & 0.489067 \\
\hline $\mathrm{H}$ & -1.312592 & 4.718016 & 0.107549 \\
\hline $\mathrm{H}$ & -2.982828 & 4.820593 & 0.652579 \\
\hline $\mathrm{H}$ & -2.797067 & 5.390824 & -1.776718 \\
\hline $\mathrm{H}$ & -3.77939 & 3.94861 & -1.546365 \\
\hline $\mathrm{H}$ & -0.81932 & 4.000824 & -2.344213 \\
\hline $\mathrm{H}$ & -2.163323 & 3.588132 & -3.404342 \\
\hline $\mathrm{H}$ & -0.997887 & 1.542952 & -2.538215 \\
\hline $\mathrm{H}$ & -2.690807 & 1.589349 & -2.047529 \\
\hline $\mathrm{H}$ & -0.298088 & 2.461823 & -0.352739 \\
\hline $\mathrm{P}$ & -0.827993 & 0.245183 & -0.026912 \\
\hline $\mathrm{C}$ & -0.748962 & 0.111789 & 1.823962 \\
\hline $\mathrm{C}$ & -2.081274 & 0.116985 & 2.574306 \\
\hline $\mathrm{C}$ & -1.85558 & 0.110815 & 4.081213 \\
\hline $\mathrm{C}$ & -1.019618 & -1.084221 & 4.511733 \\
\hline $\mathrm{C}$ & 0.289663 & -1.148093 & 3.739267 \\
\hline $\mathrm{C}$ & 0.064106 & -1.119399 & 2.234585 \\
\hline $\mathrm{H}$ & -0.488229 & -2.027902 & 1.924525 \\
\hline $\mathrm{H}$ & 1.026074 & -1.134865 & 1.697458 \\
\hline
\end{tabular}




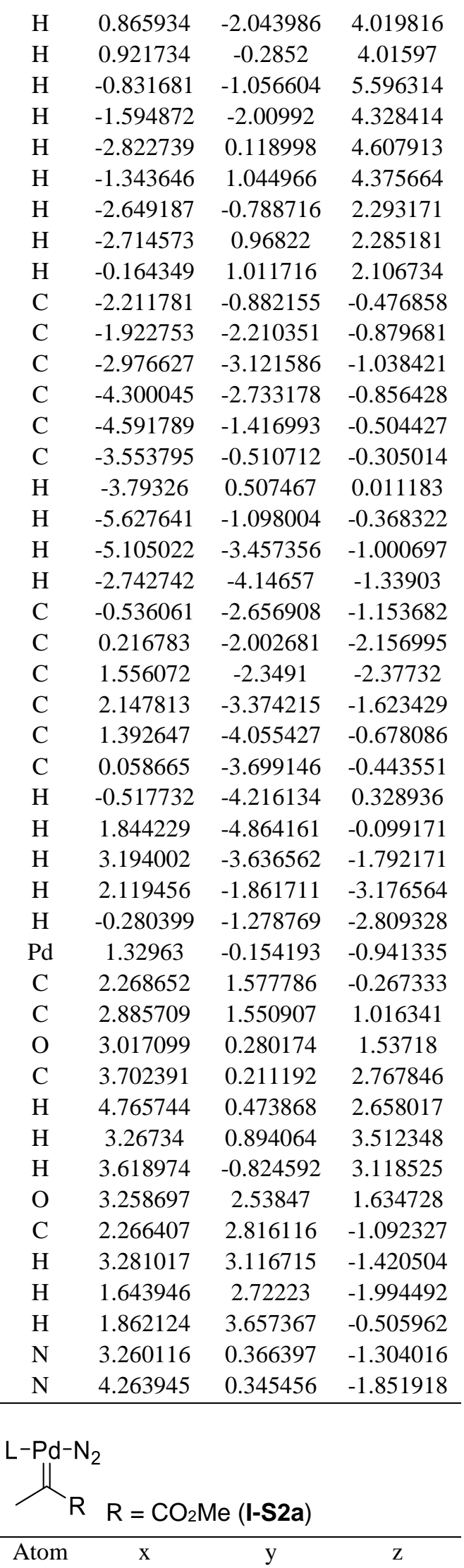




\begin{tabular}{|c|c|c|c|}
\hline $\mathrm{C}$ & 1.968041 & -1.372996 & -0.769695 \\
\hline $\mathrm{C}$ & 2.438462 & -0.937739 & -2.159066 \\
\hline $\mathrm{C}$ & 3.060774 & -2.10249 & -2.915396 \\
\hline $\mathrm{C}$ & 4.184046 & -2.745318 & -2.116549 \\
\hline $\mathrm{C}$ & 3.701991 & -3.176713 & -0.740349 \\
\hline $\mathrm{C}$ & 3.096451 & -2.014285 & 0.038697 \\
\hline $\mathrm{H}$ & 2.713405 & -2.376263 & 1.00503 \\
\hline $\mathrm{H}$ & 3.895456 & -1.286781 & 0.269032 \\
\hline $\mathrm{H}$ & 2.937916 & -3.966911 & -0.851564 \\
\hline $\mathrm{H}$ & 4.522361 & -3.630144 & -0.162536 \\
\hline $\mathrm{H}$ & 4.608103 & -3.601404 & -2.663867 \\
\hline $\mathrm{H}$ & 5.011482 & -2.020698 & -2.003015 \\
\hline $\mathrm{H}$ & 2.28099 & -2.858033 & -3.119416 \\
\hline $\mathrm{H}$ & 3.422946 & -1.766733 & -3.899555 \\
\hline $\mathrm{H}$ & 1.592352 & -0.515894 & -2.729429 \\
\hline $\mathrm{H}$ & 3.179405 & -0.12187 & -2.069638 \\
\hline $\mathrm{H}$ & 1.218415 & -2.172562 & -0.899719 \\
\hline $\mathrm{P}$ & 0.863977 & -0.090815 & -0.018256 \\
\hline $\mathrm{C}$ & 0.749696 & -0.353012 & 1.813204 \\
\hline $\mathrm{C}$ & 2.013752 & -0.095071 & 2.633672 \\
\hline $\mathrm{C}$ & 1.787598 & -0.455638 & 4.09764 \\
\hline $\mathrm{C}$ & 0.617686 & 0.316717 & 4.687216 \\
\hline $\mathrm{C}$ & -0.640183 & 0.132625 & 3.852357 \\
\hline $\mathrm{C}$ & -0.402985 & 0.475955 & 2.389494 \\
\hline $\mathrm{H}$ & -0.147375 & 1.550085 & 2.297234 \\
\hline $\mathrm{H}$ & -1.320933 & 0.316108 & 1.802995 \\
\hline $\mathrm{H}$ & -1.468589 & 0.736767 & 4.255017 \\
\hline $\mathrm{H}$ & -0.972938 & -0.918801 & 3.916745 \\
\hline $\mathrm{H}$ & 0.441069 & 0.015207 & 5.731593 \\
\hline $\mathrm{H}$ & 0.876622 & 1.390737 & 4.722924 \\
\hline $\mathrm{H}$ & 2.70623 & -0.271488 & 4.676739 \\
\hline $\mathrm{H}$ & 1.591546 & -1.539949 & 4.177558 \\
\hline $\mathrm{H}$ & 2.272776 & 0.977357 & 2.566518 \\
\hline $\mathrm{H}$ & 2.882677 & -0.640244 & 2.239052 \\
\hline $\mathrm{H}$ & 0.470246 & -1.423345 & 1.869892 \\
\hline $\mathrm{C}$ & 1.737972 & 1.52912 & -0.143524 \\
\hline $\mathrm{C}$ & 1.026906 & 2.733066 & -0.353257 \\
\hline $\mathrm{C}$ & 1.715075 & 3.954489 & -0.276413 \\
\hline $\mathrm{C}$ & 3.084468 & 4.003117 & -0.040743 \\
\hline $\mathrm{C}$ & 3.795194 & 2.817507 & 0.13204 \\
\hline $\mathrm{C}$ & 3.120809 & 1.601538 & 0.091751 \\
\hline $\mathrm{H}$ & 3.681737 & 0.680597 & 0.267245 \\
\hline $\mathrm{H}$ & 4.872295 & 2.837999 & 0.312653 \\
\hline $\mathrm{H}$ & 3.597292 & 4.966816 & 0.000693 \\
\hline $\mathrm{H}$ & 1.154825 & 4.880488 & -0.432593 \\
\hline $\mathrm{C}$ & -0.421615 & 2.792837 & -0.678474 \\
\hline $\mathrm{C}$ & -0.900784 & 2.3086 & -1.910252 \\
\hline $\mathrm{C}$ & -2.24715 & 2.45837 & -2.255426 \\
\hline $\mathrm{C}$ & -3.135124 & 3.07316 & -1.373692 \\
\hline $\mathrm{C}$ & -2.669271 & 3.551235 & -0.149324 \\
\hline $\mathrm{C}$ & -1.323461 & 3.421952 & 0.189769 \\
\hline
\end{tabular}




\begin{tabular}{cccc}
$\mathrm{H}$ & -0.959991 & 3.80675 & 1.146703 \\
$\mathrm{H}$ & -3.358801 & 4.03403 & 0.546887 \\
$\mathrm{H}$ & -4.188951 & 3.178514 & -1.641443 \\
$\mathrm{H}$ & -2.598583 & 2.090059 & -3.222763 \\
$\mathrm{H}$ & -0.195384 & 1.870181 & -2.622448 \\
$\mathrm{Pd}$ & -1.296273 & -0.205573 & -0.901573 \\
$\mathrm{C}$ & -1.124596 & -2.227862 & -0.346243 \\
$\mathrm{C}$ & -2.108891 & -2.62671 & 0.606191 \\
$\mathrm{O}$ & -2.714673 & -1.568619 & 1.275713 \\
$\mathrm{C}$ & -3.641523 & -1.94849 & 2.268215 \\
$\mathrm{H}$ & -4.509686 & -2.471733 & 1.83759 \\
$\mathrm{H}$ & -3.190209 & -2.620271 & 3.013015 \\
$\mathrm{H}$ & -3.978106 & -1.026181 & 2.757746 \\
$\mathrm{O}$ & -2.369798 & -3.78373 & 0.918515 \\
$\mathrm{C}$ & -1.069834 & -3.0292 & -1.601913 \\
$\mathrm{H}$ & -1.961817 & -2.955597 & -2.259207 \\
$\mathrm{H}$ & -0.189137 & -2.822125 & -2.235944 \\
$\mathrm{H}$ & -1.015519 & -4.092113 & -1.306857 \\
$\mathrm{~N}$ & -3.246776 & -0.442131 & -1.51822 \\
$\mathrm{~N}$ & -4.326153 & -0.572692 & -1.756079 \\
\hline
\end{tabular}

\begin{tabular}{|c|c|c|c|}
\hline Atom & $\mathrm{x}$ & $\mathrm{y}$ & $\mathrm{z}$ \\
\hline $\mathrm{C}$ & 0.245331 & 0.436486 & 1.764342 \\
\hline $\mathrm{C}$ & 0.520083 & -0.982846 & 2.260017 \\
\hline $\mathrm{C}$ & 0.32451 & -1.062461 & 3.766969 \\
\hline $\mathrm{C}$ & 1.192116 & -0.050863 & 4.502119 \\
\hline $\mathrm{C}$ & 0.973279 & 1.360619 & 3.976465 \\
\hline $\mathrm{C}$ & 1.170497 & 1.428181 & 2.467825 \\
\hline $\mathrm{H}$ & 1.019396 & 2.457324 & 2.105853 \\
\hline $\mathrm{H}$ & 2.220594 & 1.180564 & 2.224444 \\
\hline $\mathrm{H}$ & -0.053944 & 1.688653 & 4.219877 \\
\hline $\mathrm{H}$ & 1.64578 & 2.072668 & 4.480726 \\
\hline $\mathrm{H}$ & 1.006687 & -0.092229 & 5.587088 \\
\hline $\mathrm{H}$ & 2.255952 & -0.32018 & 4.368458 \\
\hline $\mathrm{H}$ & -0.740485 & -0.874084 & 3.992489 \\
\hline $\mathrm{H}$ & 0.532834 & -2.083011 & 4.124638 \\
\hline $\mathrm{H}$ & -0.141722 & -1.694465 & 1.740869 \\
\hline $\mathrm{H}$ & 1.557365 & -1.267609 & 2.004236 \\
\hline $\mathrm{H}$ & -0.805396 & 0.659948 & 2.024665 \\
\hline $\mathrm{P}$ & 0.20552 & 0.567916 & -0.091813 \\
\hline $\mathrm{C}$ & -0.991735 & 1.95605 & -0.415897 \\
\hline $\mathrm{C}$ & -1.069655 & 3.143249 & 0.5482 \\
\hline $\mathrm{C}$ & -2.242966 & 4.045948 & 0.18542 \\
\hline $\mathrm{C}$ & -2.158159 & 4.520108 & -1.256705 \\
\hline $\mathrm{C}$ & -2.090867 & 3.342713 & -2.216695 \\
\hline $\mathrm{C}$ & -0.938031 & 2.407388 & -1.876511 \\
\hline $\mathrm{H}$ & 0.01995 & 2.923984 & -2.069204 \\
\hline
\end{tabular}




\begin{tabular}{|c|c|c|c|}
\hline $\mathrm{H}$ & -0.940381 & 1.525988 & -2.540697 \\
\hline $\mathrm{H}$ & -2.002518 & 3.690462 & -3.257675 \\
\hline $\mathrm{H}$ & -3.040353 & 2.779761 & -2.166434 \\
\hline $\mathrm{H}$ & -3.010827 & 5.171785 & -1.502484 \\
\hline $\mathrm{H}$ & -1.255264 & 5.145859 & -1.381882 \\
\hline $\mathrm{H}$ & -2.28901 & 4.901053 & 0.877716 \\
\hline $\mathrm{H}$ & -3.185362 & 3.487774 & 0.33103 \\
\hline $\mathrm{H}$ & -0.145046 & 3.744958 & 0.523893 \\
\hline $\mathrm{H}$ & -1.175256 & 2.790565 & 1.585757 \\
\hline $\mathrm{H}$ & -1.942295 & 1.403864 & -0.277767 \\
\hline $\mathrm{C}$ & 1.907874 & 1.144354 & -0.51539 \\
\hline C & 2.919905 & 0.177794 & -0.745485 \\
\hline $\mathrm{C}$ & 4.253287 & 0.591745 & -0.859852 \\
\hline $\mathrm{C}$ & 4.598462 & 1.938802 & -0.801199 \\
\hline $\mathrm{C}$ & 3.602193 & 2.89 & 252 \\
\hline $\mathrm{C}$ & 2.2 & 11 & 832 \\
\hline $\mathrm{H}$ & 1.516897 & 683 & 1969 \\
\hline $\mathrm{H}$ & 3.856353 & 183 & 2802 \\
\hline $\mathrm{H}$ & 5.64357 & 2.240293 & -0.902555 \\
\hline $\mathrm{H}$ & 5.02396 & -0.16684 & -1.021705 \\
\hline $\mathrm{C}$ & 2.5909 & -1.2 & 662 \\
\hline $\mathrm{C}$ & 3.083475 & -2.2 & 45 \\
\hline $\mathrm{C}$ & 2.675088 & 317 & 559 \\
\hline $\mathrm{C}$ & 1.766397 & 983 & -1.048209 \\
\hline $\mathrm{C}$ & 1.284883 & 098 & 32955 \\
\hline $\mathrm{C}$ & 1.724435 & -1.670695 & -1.915488 \\
\hline $\mathrm{H}$ & 1.501356 & -0.970009 & 5513 \\
\hline $\mathrm{H}$ & 0.67 & 693 & 3764 \\
\hline $\mathrm{H}$ & 1.43 & 694 & 489 \\
\hline $\mathrm{H}$ & 802 & -4.2 & 0.632185 \\
\hline $\mathrm{H}$ & 3.75 & 478 & 9346 \\
\hline $\mathrm{Pd}$ & -0.479265 & -1.405531 & -1.051047 \\
\hline $\mathrm{C}$ & -2.425464 & -1.3772 & -0.917893 \\
\hline $\mathrm{C}$ & -3.054613 & -1.305673 & 3905 \\
\hline $\mathrm{O}$ & -4.301673 & -1.8 & 779 \\
\hline $\mathrm{C}$ & -4.93 & -1.9 & 3931 \\
\hline $\mathrm{H}$ & -5.113216 & -0.936142 & 2.071245 \\
\hline $\mathrm{H}$ & -5.89141 & -2.445969 & 1.491021 \\
\hline $\mathrm{H}$ & -4.328879 & -2.500928 & 2.37137 \\
\hline $\mathrm{O}$ & -2.574498 & -0.834577 & 1.412843 \\
\hline $\mathrm{C}$ & -3.23776 & -0.791514 & -2.025591 \\
\hline $\mathrm{H}$ & -4.198671 & -1.334156 & -2.067492 \\
\hline $\mathrm{H}$ & -3.517131 & 0.268535 & -1.855342 \\
\hline $\mathrm{H}$ & -2.771711 & -0.866583 & -3.017308 \\
\hline & & & \\
\hline Atom & $\mathrm{x}$ & $\mathrm{y}$ & $\mathrm{z}$ \\
\hline $\mathrm{C}$ & 1.467239 & -1.593565 & -1.071571 \\
\hline
\end{tabular}




\begin{tabular}{|c|c|c|c|}
\hline C & 1.79658 & -1.216275 & -2.517018 \\
\hline & 1.97388 & -2.452508 & -3.387052 \\
\hline & 3.011705 & -3.399437 & -2.803706 \\
\hline & 2.674186 & -3.77109 & -1.36782 \\
\hline & 2.518442 & -2.536595 & -0.486233 \\
\hline & 2.237925 & -2.841178 & 534889 \\
\hline & 3.49949 & -2.036347 & -0.401245 \\
\hline & 1.727101 & -4.342455 & 53626 \\
\hline & 3.437482 & -4.445391 & -0.948657 \\
\hline & 3.106988 & -4.302777 & -3.426252 \\
\hline $\mathrm{H}$ & 4.002979 & 0929 & -2.828825 \\
\hline & 1.005539 & -2.980934 & -3.469188 \\
\hline & 2.244868 & -2.161929 & -4.414197 \\
\hline & 1.006871 & 772 & 3313 \\
\hline & 2.723729 & -0.61525 & -2.540231 \\
\hline & 0.535612 & -2 & 212 \\
\hline $\mathrm{P}$ & 0.827167 & & 138 \\
\hline C & 0.987343 & 946 & 574 \\
\hline C & 2.393582 & 5032 & 2.274876 \\
\hline c & 2.367676 & -0.99463 & 73091 \\
\hline & 1.461147 & 366 & 575 \\
\hline & 0.063255 & 068 & 222 \\
\hline C & 0.090019 & & 22 \\
\hline $\mathrm{H}$ & 0.471141 & & 837 \\
\hline & -0.927679 & & 2774 \\
\hline & -0.575456 & 82 & 4.552969 \\
\hline & .409822 & -1 & 589 \\
\hline & 1.423215 & 708 & 226 \\
\hline & $1.8 \mathrm{~S}$ & 0.9 & 486 \\
\hline $\mathrm{H}$ & 3.38 & $-1 .($ & 401 \\
\hline & 2.006597 & -2.0 & 306 \\
\hline & 2.808811 & 0.47784 & 2.225193 \\
\hline & 3.083132 & 468 & 692371 \\
\hline & 0.558643 & 581 & 729909 \\
\hline c & 2.07 & 39 & 3211 \\
\hline $\mathrm{C}$ & 1.66 & 2.6 & 2827 \\
\hline $\mathrm{C}$ & 2.646758 & 28 & -0.402116 \\
\hline 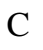 & 4.003294 & 3.303748 & -0.439801 \\
\hline C & 4.405651 & 1.970603 & -0.44479 \\
\hline & 3.44473 & 0.965274 & -0.385402 \\
\hline & 3.775853 & -0.0 & -0.349351 \\
\hline $\mathrm{H}$ & 5.466507 & 1.711287 & -0.478374 \\
\hline $\mathrm{H}$ & 4.744927 & 4.105595 & -0.473664 \\
\hline $\mathrm{H}$ & 2.323572 & 4.657268 & -0.415503 \\
\hline 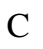 & 0.233203 & 3.011966 & -0.374731 \\
\hline $\mathrm{C}$ & -0.58 & 201 & 5488 \\
\hline $\mathrm{C}$ & -1.990231 & 2.84545 & -1.429552 \\
\hline $\mathrm{C}$ & -2.544767 & 3.514222 & -0.312684 \\
\hline $\mathrm{C}$ & -1.726457 & 3.962801 & 0.712228 \\
\hline$c$ & -0.339298 & 3.710855 & 0.680624 \\
\hline$\Pi$ & 0.290312 & 4.014103 & 1.52282 \\
\hline
\end{tabular}




\begin{tabular}{|c|c|c|c|}
\hline $\mathrm{H}$ & -2.157994 & 4.50116 & 1.559282 \\
\hline $\mathrm{H}$ & -3.621349 & 3.698511 & -0.278416 \\
\hline $\mathrm{H}$ & -2.599121 & 2.685232 & -2.324211 \\
\hline $\mathrm{H}$ & -0.099892 & 2.335955 & -2.417503 \\
\hline $\mathrm{Pd}$ & -1.246552 & 0.675129 & -0.788513 \\
\hline $\mathrm{C}$ & -3.068326 & -0.927482 & -0.974217 \\
\hline $\mathrm{C}$ & -2.938901 & -1.325462 & -2.421305 \\
\hline $\mathrm{H}$ & -3.513096 & -2.238329 & -2.657064 \\
\hline $\mathrm{H}$ & -3.28609 & -0.52277 & -3.08349 \\
\hline $\mathrm{H}$ & -1.88408 & -1.511288 & -2.668025 \\
\hline $\mathrm{N}$ & -4.061284 & -0.096761 & -0.695532 \\
\hline $\mathrm{N}$ & -4.910808 & 0.631337 & -0.444579 \\
\hline $\mathrm{C}$ & -2.608946 & -1.794359 & 0.124953 \\
\hline $\mathrm{C}$ & -1.864631 & -2.956029 & -0.159017 \\
\hline $\mathrm{C}$ & -2.903787 & -1.510023 & 1.472876 \\
\hline $\mathrm{C}$ & -1.400572 & -3.772612 & 0.868964 \\
\hline $\mathrm{H}$ & -1.641294 & -3.220982 & -1.195438 \\
\hline $\mathrm{C}$ & -2.447579 & -2.337089 & 2.490864 \\
\hline $\mathrm{H}$ & -3.482574 & -0.616237 & 1.723881 \\
\hline $\mathrm{C}$ & -1.682743 & -3.4704 & 2.201129 \\
\hline $\mathrm{H}$ & -0.818062 & -4.664334 & 0.621011 \\
\hline $\mathrm{H}$ & -2.69086 & -2.091783 & 3.527714 \\
\hline $\mathrm{H}$ & -1.32248 & -4.116321 & 3.004803 \\
\hline \multicolumn{4}{|c|}{$\mathrm{R}=\mathrm{Ph}(\mathbf{T S}-\mathrm{S} \mathbf{1 b})$} \\
\hline Atom & $\mathrm{x}$ & $y$ & $\mathrm{Z}$ \\
\hline $\mathrm{C}$ & -1.113454 & 2.129524 & -0.551718 \\
\hline $\mathrm{C}$ & -1.800987 & 2.179325 & -1.917961 \\
\hline $\mathrm{C}$ & -1.664274 & 3.552221 & -2.561103 \\
\hline $\mathrm{C}$ & -2.161259 & 4.654807 & -1.638614 \\
\hline $\mathrm{C}$ & -1.45599 & 4.601303 & -0.292505 \\
\hline $\mathrm{C}$ & -1.615987 & 3.239384 & 0.372722 \\
\hline $\mathrm{H}$ & -1.067936 & 3.227472 & 1.327489 \\
\hline $\mathrm{H}$ & -2.681427 & 3.093279 & 0.624717 \\
\hline $\mathrm{H}$ & -0.379466 & 4.805955 & -0.436118 \\
\hline $\mathrm{H}$ & -1.826426 & 5.393523 & 0.376473 \\
\hline $\mathrm{H}$ & -2.02839 & 5.641768 & -2.108046 \\
\hline $\mathrm{H}$ & -3.249732 & 4.5392 & -1.484029 \\
\hline $\mathrm{H}$ & -0.601677 & 3.733779 & -2.802656 \\
\hline $\mathrm{H}$ & -2.200423 & 3.575027 & -3.522416 \\
\hline $\mathrm{H}$ & -1.382464 & 1.399143 & -2.578196 \\
\hline $\mathrm{H}$ & -2.872629 & 1.932694 & -1.800435 \\
\hline $\mathrm{H}$ & -0.038179 & 2.335882 & -0.72383 \\
\hline $\mathrm{P}$ & -0.962056 & 0.37798 & 0.043422 \\
\hline $\mathrm{C}$ & -0.498018 & 0.492874 & 1.837105 \\
\hline $\mathrm{C}$ & -1.619605 & 0.84789 & 2.812856 \\
\hline $\mathrm{C}$ & -1.06693 & 1.048837 & 4.2191 \\
\hline
\end{tabular}




\begin{tabular}{|c|c|c|c|}
\hline $\mathrm{C}$ & -0.310833 & -0.18065 & 677 \\
\hline & 0.767681 & -0.596479 & 3.712252 \\
\hline & .203428 & -0.780754 & 2.311884 \\
\hline & .526592 & -1.613002 & 2.306328 \\
\hline $\mathrm{H}$ & .999843 & -1.061834 & 1.605339 \\
\hline $\mathrm{H}$ & 1.26938 & -1.518459 & 04537 \\
\hline & .558099 & 0.174624 & 3.673033 \\
\hline & .123026 & -0.000966 & 7672 \\
\hline & .026455 & -1.013201 & 4.830826 \\
\hline $\mathrm{H}$ & .882685 & 1.301733 & 914593 \\
\hline $\mathrm{H}$ & -0.388739 & 1.92 & 218311 \\
\hline $\mathrm{H}$ & -2.350515 & 0.018807 & 4501 \\
\hline $\mathrm{H}$ & -2.184038 & 1.73 & 489076 \\
\hline H & .257595 & & 3576 \\
\hline C & -2.629871 & -0.3 & 975 \\
\hline $\mathrm{C}$ & -2.745373 & -1.7 & 325 \\
\hline $\mathrm{C}$ & -3.996726 & -2.4 & 199 \\
\hline $\mathrm{C}$ & -5.131746 & -1.6 & \\
\hline $\mathrm{C}$ & -5.029306 & -0.297967 & 6349 \\
\hline $\mathrm{C}$ & -3.787558 & 0.322972 & 225 \\
\hline $\mathrm{H}$ & -3.713814 & 1.39 & 57 \\
\hline $\mathrm{H}$ & -5.913831 & 0.29 & 712 \\
\hline $\mathrm{H}$ & -6.0 & -2 & \\
\hline $\mathrm{H}$ & -4.07 & -3.4 & 925 \\
\hline $\mathrm{C}$ & -1.572176 & -2.613353 & 8462 \\
\hline $\mathrm{C}$ & -0.909824 & -2.3 & -1.80345 \\
\hline c & 0.254058 & -3.071615 & 3613 \\
\hline $\mathrm{C}$ & 0.755178 & -4.0 & 7662 \\
\hline $\mathrm{C}$ & 0.0 & -4.3 & 37 \\
\hline $\mathrm{C}$ & 577 & -3.6 & 502 \\
\hline $\mathrm{H}$ & -1.595083 & -3.820442 & 1762 \\
\hline $\mathrm{H}$ & 0.450665 & -5.098622 & 6797 \\
\hline H & 1.668066 & -4.588281 & -1.513812 \\
\hline & 0.740866 & 8206 & 6353 \\
\hline $\mathrm{H}$ & -1.3 & -1.6 & 162 \\
\hline $\mathrm{Pd}$ & 17 & -0.6 & 741 \\
\hline $\mathrm{C}$ & 2.24057 & 0.854149 & -1.014566 \\
\hline $\mathrm{C}$ & 2.283764 & 1.96385 & -2.005561 \\
\hline $\mathrm{H}$ & 3.269659 & 2.076662 & -2.502572 \\
\hline $\mathrm{H}$ & 1.530075 & 1.84 & -2.796978 \\
\hline $\mathrm{H}$ & 2.05 & 2.93 & -1.5 \\
\hline $\mathrm{C}$ & 3.221615 & 0.69 & 0.016026 \\
\hline $\mathrm{C}$ & 4.056764 & 1.782081 & 0.379715 \\
\hline $\mathrm{C}$ & 4.979127 & 1.673132 & 1.414658 \\
\hline $\mathrm{C}$ & 5.14344 & 0.476721 & 2.114853 \\
\hline $\mathrm{C}$ & 4.356477 & -0.621182 & 1.749776 \\
\hline $\mathrm{C}$ & 3.412286 & -0.51731 & 0.739384 \\
\hline $\mathrm{H}$ & 2.809694 & -1.392966 & 0.469417 \\
\hline $\mathrm{H}$ & 4.478487 & -1.576576 & 2.268992 \\
\hline $\mathrm{H}$ & 5.874777 & 0.396283 & 2.921704 \\
\hline $\mathrm{H}$ & 5.592048 & 2.542361 & 1.670936 \\
\hline
\end{tabular}




\begin{tabular}{cccc}
$\mathrm{H}$ & 3.962979 & 2.730345 & -0.156001 \\
$\mathrm{~N}$ & 2.604632 & -0.656834 & -2.176807 \\
$\mathrm{~N}$ & 3.349928 & -1.033821 & -2.956733 \\
\hline
\end{tabular}

\begin{tabular}{|c|c|c|c|}
\hline Atom & $\mathrm{x}$ & $\mathrm{y}$ & $\mathrm{z}$ \\
\hline C & 0.121443 & 0.143717 & 1.802267 \\
\hline $\mathrm{C}$ & 0.439237 & -1.328613 & 2.079814 \\
\hline $\mathrm{C}$ & -0.04075 & -1.74157 & 3.462984 \\
\hline $\mathrm{C}$ & 0.560885 & -0.860603 & 4.547915 \\
\hline $\mathrm{C}$ & 0.318012 & 0.613951 & 4.263286 \\
\hline $\mathrm{C}$ & 0.801806 & 1.001563 & 2.870662 \\
\hline $\mathrm{H}$ & 0.649602 & 2.076479 & 2.699874 \\
\hline $\mathrm{H}$ & 1.893286 & 0.840368 & 2.809848 \\
\hline $\mathrm{H}$ & -0.762387 & 0.832263 & 4.344487 \\
\hline $\mathrm{H}$ & 0.810147 & 1.241581 & 5.022873 \\
\hline $\mathrm{H}$ & 0.165649 & -1.13559 & 5.538291 \\
\hline $\mathrm{H}$ & 1.649997 & -1.041609 & 4.596256 \\
\hline $\mathrm{H}$ & -1.142861 & -1.666122 & 3.494573 \\
\hline $\mathrm{H}$ & 0.195646 & -2.801382 & 3.64712 \\
\hline $\mathrm{H}$ & 0.013121 & -1.976047 & 1.295369 \\
\hline $\mathrm{H}$ & 1.534997 & -1.466964 & 2.013819 \\
\hline $\mathrm{H}$ & -0.978165 & 0.276947 & 1.871212 \\
\hline $\mathrm{P}$ & 0.477147 & 0.560615 & 0.025088 \\
\hline $\mathrm{C}$ & -0.360921 & 2.186479 & -0.340158 \\
\hline C & -0.530529 & 3.273926 & 0.722094 \\
\hline $\mathrm{C}$ & -1.395442 & 4.409697 & 0.184706 \\
\hline $\mathrm{C}$ & -0.830249 & 4.988718 & -1.10226 \\
\hline $\mathrm{C}$ & -0.668686 & 3.909916 & -2.161432 \\
\hline $\mathrm{C}$ & 0.182666 & 2.754898 & -1.653737 \\
\hline $\mathrm{H}$ & 1.220804 & 3.103393 & -1.502037 \\
\hline $\mathrm{H}$ & 0.241999 & 1.953432 & -2.41062 \\
\hline $\mathrm{H}$ & -0.232281 & 4.327151 & -3.08228 \\
\hline $\mathrm{H}$ & -1.665126 & 3.526287 & -2.445119 \\
\hline $\mathrm{H}$ & -1.470492 & 5.804045 & -1.473235 \\
\hline $\mathrm{H}$ & 0.153279 & 5.449041 & -0.894694 \\
\hline $\mathrm{H}$ & -1.509106 & 5.191725 & 0.951603 \\
\hline $\mathrm{H}$ & -2.413504 & 4.023721 & -0.00602 \\
\hline $\mathrm{H}$ & 0.444076 & 3.688027 & 1.034478 \\
\hline $\mathrm{H}$ & -0.993663 & 2.854168 & 1.628154 \\
\hline $\mathrm{H}$ & -1.38453 & 1.821346 & -0.55175 \\
\hline $\mathrm{C}$ & 2.301873 & 0.836549 & 0.043423 \\
\hline $\mathrm{C}$ & 3.167529 & -0.23712 & -0.287858 \\
\hline $\mathrm{C}$ & 4.548555 & -0.083225 & -0.100618 \\
\hline $\mathrm{C}$ & 5.086417 & 1.115477 & 0.358355 \\
\hline $\mathrm{C}$ & 4.242573 & 2.185933 & 0.646669 \\
\hline $\mathrm{C}$ & 2.865382 & 2.036276 & 0.501954 \\
\hline $\mathrm{H}$ & 2.212545 & 2.868153 & 0.775664 \\
\hline
\end{tabular}




\begin{tabular}{cccc}
$\mathrm{H}$ & 4.652831 & 3.134251 & 1.001573 \\
$\mathrm{H}$ & 6.167314 & 1.216782 & 0.480667 \\
$\mathrm{H}$ & 5.205961 & -0.920225 & -0.351439 \\
$\mathrm{C}$ & 2.635516 & -1.50583 & -0.835151 \\
$\mathrm{C}$ & 2.820432 & -2.724791 & -0.194057 \\
$\mathrm{C}$ & 2.212315 & -3.892679 & -0.692596 \\
$\mathrm{C}$ & 1.410673 & -3.840005 & -1.819792 \\
$\mathrm{C}$ & 1.235696 & -2.621303 & -2.509409 \\
$\mathrm{C}$ & 1.874309 & -1.459793 & -2.032319 \\
$\mathrm{H}$ & 1.911737 & -0.555314 & -2.647628 \\
$\mathrm{H}$ & 0.735861 & -2.609085 & -3.480097 \\
$\mathrm{H}$ & 0.927707 & -4.744785 & -2.195416 \\
$\mathrm{H}$ & 2.363182 & -4.842525 & -0.174218 \\
$\mathrm{H}$ & 3.405625 & -2.761416 & 0.729364 \\
$\mathrm{Pd}$ & -0.374407 & -1.043927 & -1.406264 \\
$\mathrm{C}$ & -2.315264 & -0.68028 & -1.533152 \\
$\mathrm{C}$ & -2.690074 & 0.360117 & -2.54608 \\
$\mathrm{H}$ & -3.53526 & -0.013334 & -3.15323 \\
$\mathrm{H}$ & -3.041768 & 1.322926 & -2.118464 \\
$\mathrm{H}$ & -1.885255 & 0.580112 & -3.26206 \\
$\mathrm{C}$ & -3.265948 & -0.838925 & -0.440619 \\
$\mathrm{C}$ & -2.951235 & -1.66041 & 0.670516 \\
$\mathrm{C}$ & -4.548757 & -0.233534 & -0.433338 \\
$\mathrm{C}$ & -3.832742 & -1.839351 & 1.7261 \\
$\mathrm{H}$ & -1.98082 & -2.167883 & 0.661191 \\
$\mathrm{C}$ & -5.445435 & -0.436798 & 0.610482 \\
$\mathrm{H}$ & -4.853925 & 0.399551 & -1.269747 \\
$\mathrm{C}$ & -5.092702 & -1.23053 & 1.702371 \\
$\mathrm{H}$ & -3.551501 & -2.479207 & 2.56718 \\
$\mathrm{H}$ & -6.430943 & 0.036051 & 0.577654 \\
$\mathrm{H}$ & -5.797764 & -1.386033 & 2.522512 \\
\hline & & & \\
\hline & & & \\
\hline
\end{tabular}

\begin{tabular}{cccc}
\multicolumn{4}{l}{$L-P d(I-S 4)$} \\
\hline Atom & $\mathrm{x}$ & $\mathrm{y}$ & $\mathrm{Z}$ \\
\hline $\mathrm{C}$ & -2.273513 & -0.715204 & -0.684477 \\
$\mathrm{C}$ & -2.452518 & -2.066906 & 0.008758 \\
$\mathrm{C}$ & -3.730018 & -2.761723 & -0.440357 \\
$\mathrm{C}$ & -4.946469 & -1.868086 & -0.253193 \\
$\mathrm{C}$ & -4.762949 & -0.534212 & -0.960786 \\
$\mathrm{C}$ & -3.499851 & 0.180409 & -0.491208 \\
$\mathrm{H}$ & -3.379184 & 1.129423 & -1.037929 \\
$\mathrm{H}$ & -3.631822 & 0.455231 & 0.56921 \\
$\mathrm{H}$ & -4.697214 & -0.705965 & -2.050489 \\
$\mathrm{H}$ & -5.64148 & 0.112662 & -0.810514 \\
$\mathrm{H}$ & -5.858447 & -2.372608 & -0.608641 \\
$\mathrm{H}$ & -5.103583 & -1.687651 & 0.826136 \\
$\mathrm{H}$ & -3.639616 & -3.032667 & -1.507775 \\
$\mathrm{H}$ & -3.857143 & -3.712008 & 0.101566 \\
$\mathrm{H}$ & -1.572837 & -2.704492 & -0.182716 \\
$\mathrm{H}$ & -2.481502 & -1.917871 & 1.103002 \\
\hline
\end{tabular}




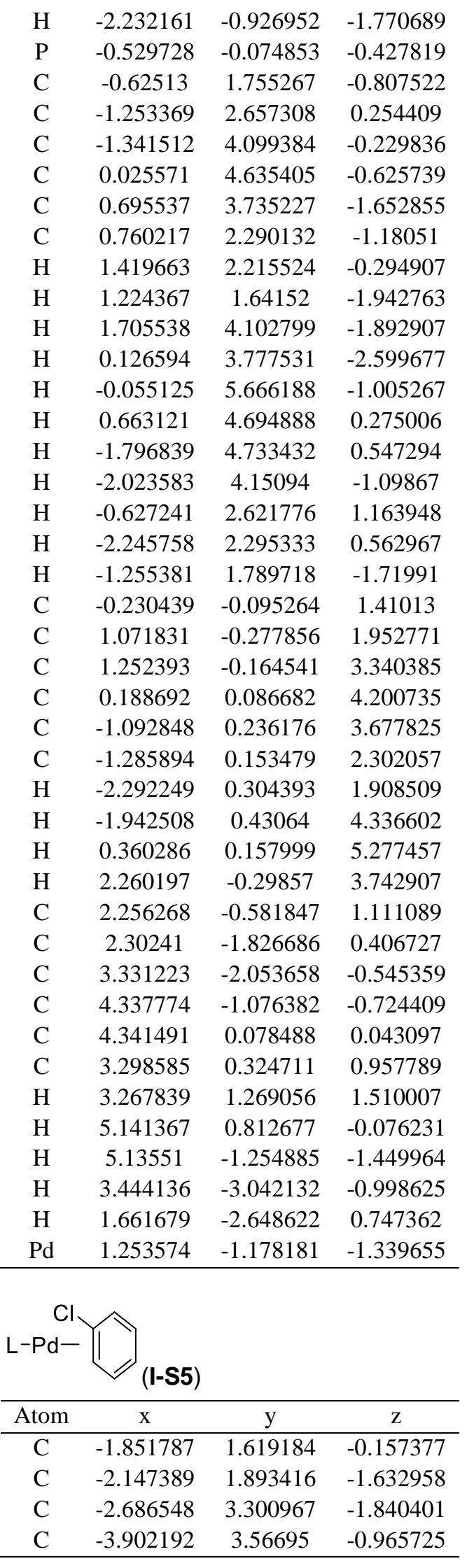




\begin{tabular}{|c|c|c|c|}
\hline $\mathrm{C}$ & 3.590706 & 938 & 194 \\
\hline & -3.074199 & 1.889506 & 0.722519 \\
\hline & 826778 & .74372 & 786184 \\
\hline & -3.890165 & 1.180169 & 500144 \\
\hline & -2.825141 & 4.026637 & 842279 \\
\hline & -4.477189 & 3.489166 & 127842 \\
\hline & -4.265636 & 4.596791 & -1.107086 \\
\hline & -4.73177 & 2.908406 & -1.282957 \\
\hline & -1.893178 & 4.028867 & -1.593731 \\
\hline & -2.926636 & 3.463976 & -2.902609 \\
\hline $\mathrm{H}$ & -1.233778 & 1.735879 & -2.23 \\
\hline $\mathrm{H}$ & -2.884001 & 1.15709 & -2.004576 \\
\hline & -1.086953 & 2.362299 & 0.147628 \\
\hline $\mathrm{P}$ & -0.849156 & 0.058531 & \\
\hline C & -0.924352 & -0.343376 & 1.8 \\
\hline $\mathrm{C}$ & -2.197289 & -1.023906 & 65 \\
\hline C & -2.171186 & 295 & \\
\hline $\mathrm{C}$ & -0.94157 & -1.970103 & \\
\hline 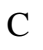 & 0.337287 & -1.331838 & \\
\hline $\mathrm{C}$ & 0.301413 & -1.15 & \\
\hline $\mathrm{H}$ & 0.267722 & -2.142296 & 49 \\
\hline & 225066 & -0.6 & 1.9 \\
\hline & 54 & -1.9 & 4.0 \\
\hline $\mathrm{H}$ & .471706 & -0.3 & \\
\hline I & -0.916952 & -2.0 & \\
\hline & 182 & -3.0 & 3.9 \\
\hline & .091748 & -1.6 & 4.1 \\
\hline & 3193 & -0.1 & \\
\hline & 735 & -2.0 & 1.8 \\
\hline & -3.09 & -0.4 & \\
\hline & -0.843355 & 0.65 & \\
\hline & -1.789959 & -1.321887 & -0.7 \\
\hline & -1.079205 & -2.4 & -1.2 \\
\hline & 6179 & -3.533156 & 6619 \\
\hline & -3 & -3.5 & -1 . \\
\hline & -3.8 & -2.4 & -1.2 \\
\hline C & -3.192552 & -1.363836 & -0.7 \\
\hline & -3.758644 & -0.525293 & -0.367534 \\
\hline & -4.982338 & -2.453417 & -1.28453 \\
\hline & & & \\
\hline & -1.23 & -4.3 & $-2.1^{\prime}$ \\
\hline C & 0.40 & -2.46528 & -1.38 \\
\hline $\mathrm{C}$ & 1.089168 & -1.56012 & -2.229454 \\
\hline 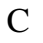 & 2.48794 & -1.593349 & -2.308894 \\
\hline C & 3.212228 & -2.530361 & -1.560607 \\
\hline & & -3.4 & -0.7 \\
\hline & 1.141695 & -3.407088 & -0.668895 \\
\hline & 0.615771 & -4.111638 & -0.017923 \\
\hline & 3.099132 & -4.177773 & -0.175572 \\
\hline 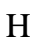 & 4.302767 & -2.54986 & -1.621139 \\
\hline 11 & 3.004501 & -0.915971 & -2.993376 \\
\hline
\end{tabular}




\begin{tabular}{cccc}
$\mathrm{H}$ & 0.514722 & -0.908797 & -2.895024 \\
$\mathrm{Pd}$ & 1.365317 & 0.347858 & -0.677578 \\
$\mathrm{C}$ & 2.239813 & 2.156932 & 0.104184 \\
$\mathrm{C}$ & 3.285945 & 1.417501 & -0.545473 \\
$\mathrm{C}$ & 4.168691 & 0.663193 & 0.272714 \\
$\mathrm{C}$ & 4.05269 & 0.661329 & 1.650231 \\
$\mathrm{C}$ & 3.061982 & 1.450817 & 2.27617 \\
$\mathrm{C}$ & 2.181675 & 2.20466 & 1.527936 \\
$\mathrm{H}$ & 1.430406 & 2.839713 & 2.003177 \\
$\mathrm{H}$ & 2.990322 & 1.470161 & 3.366697 \\
$\mathrm{H}$ & 4.746574 & 0.075948 & 2.256999 \\
$\mathrm{H}$ & 4.970413 & 0.098394 & -0.211363 \\
$\mathrm{H}$ & 3.552221 & 1.639925 & -1.582367 \\
$\mathrm{Cl}$ & 1.48166 & 3.519088 & -0.771552 \\
\hline
\end{tabular}

$$
\begin{aligned}
& \text { L-Pd--Ph } \\
& \text { 'cí }
\end{aligned}
$$

(TS-S2)

\begin{tabular}{cccc}
\hline Atom & $\mathrm{x}$ & $\mathrm{y}$ & $\mathrm{z}$ \\
\hline $\mathrm{C}$ & -2.112668 & 1.762436 & -0.252884 \\
$\mathrm{C}$ & -2.062948 & 2.219679 & -1.712282 \\
$\mathrm{C}$ & -2.606115 & 3.632947 & -1.870747 \\
$\mathrm{C}$ & -4.005169 & 3.762241 & -1.288375 \\
$\mathrm{C}$ & -4.037046 & 3.321043 & 0.166965 \\
$\mathrm{C}$ & -3.519611 & 1.896592 & 0.332729 \\
$\mathrm{H}$ & -3.524443 & 1.621878 & 1.399071 \\
$\mathrm{H}$ & -4.226907 & 1.208655 & -0.160864 \\
$\mathrm{H}$ & -3.410688 & 4.004401 & 0.768124 \\
$\mathrm{H}$ & -5.054787 & 3.404205 & 0.579356 \\
$\mathrm{H}$ & -4.373454 & 4.795092 & -1.388615 \\
$\mathrm{H}$ & -4.702863 & 3.135733 & -1.87406 \\
$\mathrm{H}$ & -1.930652 & 4.338711 & -1.355022 \\
$\mathrm{H}$ & -2.596371 & 3.926698 & -2.931926 \\
$\mathrm{H}$ & -1.027721 & 2.155301 & -2.08828 \\
$\mathrm{H}$ & -2.65375 & 1.526653 & -2.338258 \\
$\mathrm{H}$ & -1.481578 & 2.473364 & 0.317171 \\
$\mathrm{P}$ & -1.105904 & 0.207214 & -0.009082 \\
$\mathrm{Pd}$ & 1.180108 & 0.782403 & 0.123289 \\
$\mathrm{C}$ & 3.121113 & 1.370047 & 0.450142 \\
$\mathrm{C}$ & 3.812185 & 0.39326 & 1.187318 \\
$\mathrm{C}$ & 5.02459 & -0.081339 & 0.69461 \\
$\mathrm{C}$ & 5.573666 & 0.441577 & -0.479968 \\
$\mathrm{C}$ & 4.902499 & 1.456926 & -1.168347 \\
$\mathrm{C}$ & 3.686141 & 1.948236 & -0.700346 \\
$\mathrm{H}$ & 3.166901 & 2.75935 & -1.215176 \\
$\mathrm{H}$ & 5.334505 & 1.878949 & -2.080056 \\
$\mathrm{H}$ & 6.535097 & 0.074557 & -0.846263 \\
$\mathrm{H}$ & 5.54913 & -0.870856 & 1.240154 \\
$\mathrm{H}$ & 3.385996 & 0.002102 & 2.114227 \\
$\mathrm{C}$ & -1.759965 & -1.068222 & -1.16898 \\
\hline & & &
\end{tabular}




\begin{tabular}{cccc}
$\mathrm{C}$ & -0.937533 & -2.149758 & -1.568276 \\
$\mathrm{C}$ & 0.518676 & -2.237127 & -1.285914 \\
$\mathrm{C}$ & 1.417111 & -1.315178 & -1.85309 \\
$\mathrm{C}$ & 2.792249 & -1.46837 & -1.68276 \\
$\mathrm{C}$ & 3.291478 & -2.522933 & -0.919013 \\
$\mathrm{C}$ & 2.410972 & -3.433336 & -0.338919 \\
$\mathrm{C}$ & 1.035884 & -3.298187 & -0.534193 \\
$\mathrm{H}$ & 0.345935 & -4.023763 & -0.092468 \\
$\mathrm{H}$ & 2.793783 & -4.262832 & 0.260645 \\
$\mathrm{H}$ & 4.369681 & -2.630179 & -0.779121 \\
$\mathrm{H}$ & 3.478492 & -0.749652 & -2.137797 \\
$\mathrm{H}$ & 1.029066 & -0.502486 & -2.474959 \\
$\mathrm{C}$ & -1.508459 & -3.204893 & -2.298849 \\
$\mathrm{C}$ & -2.846291 & -3.191389 & -2.678048 \\
$\mathrm{C}$ & -3.646391 & -2.106852 & -2.326933 \\
$\mathrm{C}$ & -3.104752 & -1.071368 & -1.572195 \\
$\mathrm{H}$ & -3.756278 & -0.248682 & -1.274427 \\
$\mathrm{H}$ & -4.696619 & -2.072084 & -2.625549 \\
$\mathrm{H}$ & -3.258837 & -4.020834 & -3.257248 \\
$\mathrm{H}$ & -0.866327 & -4.03971 & -2.593336 \\
$\mathrm{C}$ & -1.656065 & -0.440871 & 1.659262 \\
$\mathrm{C}$ & -2.972871 & -1.215154 & 1.693046 \\
$\mathrm{C}$ & -3.353619 & -1.593393 & 3.11897 \\
$\mathrm{C}$ & -2.251166 & -2.39762 & 3.790358 \\
$\mathrm{C}$ & -0.920414 & -1.662268 & 3.739212 \\
$\mathrm{C}$ & -0.548012 & -1.265414 & 2.318038 \\
$\mathrm{H}$ & -0.368453 & -2.17344 & 1.712357 \\
$\mathrm{H}$ & 0.402259 & -0.702801 & 2.300162 \\
$\mathrm{H}$ & -0.1207 & -2.273491 & 4.185859 \\
$\mathrm{H}$ & -0.983662 & -0.750453 & 4.360475 \\
$\mathrm{H}$ & -2.522465 & -2.637702 & 4.830355 \\
$\mathrm{H}$ & -2.149699 & -3.36927 & 3.273238 \\
$\mathrm{H}$ & -4.301632 & -2.154152 & 3.122421 \\
$\mathrm{H}$ & -3.545387 & -0.673 & 3.700907 \\
$\mathrm{H}$ & -2.85914 & -2.136699 & 1.092784 \\
$\mathrm{H}$ & -3.787066 & -0.650787 & 1.212598 \\
$\mathrm{H}$ & -1.772412 & 0.488166 & 2.253846 \\
$\mathrm{Cl}$ & 1.968226 & 2.656612 & 1.561846 \\
\hline & & &
\end{tabular}

\begin{tabular}{cccc}
$\begin{array}{l}\text { L-Pd-Ph } \\
\text { I } \\
\text { Cl }\end{array}$ & $($ I-S6 $)$ & & \\
\hline Atom & $\mathrm{x}$ & $\mathrm{y}$ & $\mathrm{z}$ \\
\hline $\mathrm{C}$ & -1.904885 & 1.892333 & -0.243034 \\
$\mathrm{C}$ & -1.998064 & 2.245315 & -1.729426 \\
$\mathrm{C}$ & -2.386418 & 3.704318 & -1.927099 \\
$\mathrm{C}$ & -3.667765 & 4.046633 & -1.182736 \\
$\mathrm{C}$ & -3.553408 & 3.703855 & 0.294564 \\
$\mathrm{C}$ & -3.194158 & 2.237933 & 0.502937 \\
$\mathrm{H}$ & -3.082717 & 2.029682 & 1.578342 \\
$\mathrm{H}$ & -4.036549 & 1.615147 & 0.151312 \\
\hline
\end{tabular}




\begin{tabular}{|c|c|c|c|}
\hline & 719 & 47 & 85 \\
\hline & -4.488113 & 3.942776 & 0.82542 \\
\hline & 3.919118 & 5.110278 & -1.315537 \\
\hline & -4.508866 & 3.480966 & -1.624515 \\
\hline & 1.567824 & 4.347061 & -1.558043 \\
\hline & 2.48644 & 3.927114 & -3.000772 \\
\hline & -1.03715 & 978 & -2.228688 \\
\hline & -2.745242 & 1.595955 & -2.222196 \\
\hline & -1.113266 & 2.528167 & 0.19926 \\
\hline & -1.118064 & 0.23126 & -0.007243 \\
\hline $\mathrm{P}$ & .328941 & 0.40 & -0.17911 \\
\hline $\mathrm{C}$ & 018 & & 681 \\
\hline $\mathrm{C}$ & -1.2 & -2.1 & -1.5 \\
\hline $\mathrm{C}$ & -2.008176 & -0.9 & -1.044064 \\
\hline $\mathrm{C}$ & -3.400256 & -0.9 & -1.209545 \\
\hline $\mathrm{C}$ & -4.080559 & 797 & -1.853402 \\
\hline c & -3.37 & -3.1 & -2 . \\
\hline $\mathrm{C}$ & -1.99 & -3.1 & -2.1 \\
\hline$\Pi$ & -1.42 & $-4 .($ & -2.5 \\
\hline $\mathrm{H}$ & -3.898993 & -3.9 & -2.818449 \\
\hline $\mathrm{H}$ & -5.16 & -1.5 & -1.972987 \\
\hline $\mathrm{r}$ & -3.96 & -0.1 & -0.806636 \\
\hline C & 0.94 & -1.0 & -2.0 \\
\hline $\mathrm{C}$ & 2.3 & -1.0 & -1 . \\
\hline $\mathrm{C}$ & & & 195 \\
\hline $\mathrm{C}$ & 2.26 & -3.2 & \\
\hline $\mathrm{C}$ & 096 & -3.2 & -0.9 \\
\hline $\mathrm{r}$ & 0.28 & -4.0 & -0.576644 \\
\hline & 7 & -4.1 & -0.4 \\
\hline & 5 & -2.2 & 708 \\
\hline H & 8 & -0. & -2 \\
\hline $\mathrm{H}$ & & -0.3 & -2.609625 \\
\hline C & 3.33 & & 0.029488 \\
\hline $\mathrm{C}$ & 4.026 & -0.0 & 0.972489 \\
\hline $\mathrm{C}$ & 5.40274 & & 1.144907 \\
\hline $\mathrm{C}$ & 6.09 & 37 & .379354 \\
\hline $\mathrm{C}$ & 5.40 & 1.8 & -0.5 \\
\hline $\mathrm{C}$ & 4.02 & 1.6 & -0.7 \\
\hline $\mathrm{H}$ & 3.500445 & 2.25 & -1.457997 \\
\hline $\mathrm{H}$ & 5.93 & 2.5 & -1.151909 \\
\hline H & 7.172 & 1.16 & 0.515406 \\
\hline & 5033 & -0.5 & 1.888448 \\
\hline $\mathrm{H}$ & 3.49 & -0.8 & 1.58 \\
\hline $\mathrm{C}$ & -1.488 & -0.3 & 405 \\
\hline $\mathrm{C}$ & -2.903612 & 005 & 2.001157 \\
\hline $\mathrm{C}$ & -3.093405 & -1.135712 & 3.481414 \\
\hline $\mathrm{C}$ & -2.072003 & -2.1 & 3.969859 \\
\hline & 06520 & -1.69787 & 3.664579 \\
\hline $\mathrm{C}$ & -0.46523 & -1.362416 & 2.192106 \\
\hline $\mathrm{H}$ & -0.581514 & -2.277661 & 1.579105 \\
\hline 11 & 0.559399 & -0.995371 & 2.013753 \\
\hline
\end{tabular}




\begin{tabular}{cccc}
$\mathrm{H}$ & 0.076154 & -2.462447 & 3.974776 \\
$\mathrm{H}$ & -0.416411 & -0.79809 & 4.260279 \\
$\mathrm{H}$ & -2.196391 & -2.33893 & 5.04782 \\
$\mathrm{H}$ & -2.261335 & -3.119248 & 3.471126 \\
$\mathrm{H}$ & -4.118436 & -1.494563 & 3.664871 \\
$\mathrm{H}$ & -2.991247 & -0.200735 & 4.061666 \\
$\mathrm{H}$ & -3.071209 & -1.75135 & 1.416626 \\
$\mathrm{H}$ & -3.668494 & -0.115538 & 1.657351 \\
$\mathrm{H}$ & -1.303166 & 0.604869 & 2.309841 \\
$\mathrm{Cl}$ & 1.117306 & 1.959609 & 1.587212 \\
\hline
\end{tabular}<smiles>[3H][Pb]([3H])(Cl)c1ccccc1</smiles>

\begin{tabular}{cccc}
\hline Atom & $\mathrm{x}$ & $\mathrm{y}$ & $\mathrm{z}$ \\
\hline $\mathrm{P}$ & -0.067182 & 0.129436 & 0.02398 \\
$\mathrm{C}$ & 0.808779 & 0.50387 & 1.603419 \\
$\mathrm{C}$ & -0.084705 & 0.553981 & 2.693033 \\
$\mathrm{C}$ & 0.339858 & 0.794555 & 3.992167 \\
$\mathrm{C}$ & 1.699533 & 0.958585 & 4.242867 \\
$\mathrm{C}$ & 2.599942 & 0.89158 & 3.188041 \\
$\mathrm{C}$ & 2.191723 & 0.682987 & 1.857323 \\
$\mathrm{C}$ & 3.300808 & 0.63355 & 0.863905 \\
$\mathrm{C}$ & 3.521878 & 1.648276 & -0.075865 \\
$\mathrm{C}$ & 4.615682 & 1.598861 & -0.939512 \\
$\mathrm{C}$ & 5.518513 & 0.539403 & -0.868922 \\
$\mathrm{C}$ & 5.326688 & -0.463969 & 0.08035 \\
$\mathrm{C}$ & 4.233356 & -0.412429 & 0.941347 \\
$\mathrm{H}$ & 4.085479 & -1.202458 & 1.683438 \\
$\mathrm{H}$ & 6.032397 & -1.295084 & 0.150923 \\
$\mathrm{H}$ & 6.376001 & 0.501482 & -1.544662 \\
$\mathrm{H}$ & 4.76853 & 2.402682 & -1.663816 \\
$\mathrm{H}$ & 2.836939 & 2.49668 & -0.119919 \\
$\mathrm{H}$ & 3.66921 & 1.013537 & 3.380852 \\
$\mathrm{H}$ & 2.061772 & 1.127317 & 5.259411 \\
$\mathrm{H}$ & -0.38719 & 0.826519 & 4.805933 \\
$\mathrm{H}$ & -1.146649 & 0.364892 & 2.504854 \\
$\mathrm{C}$ & 1.104176 & -0.460366 & -1.273317 \\
$\mathrm{C}$ & 0.411154 & -0.56321 & -2.635436 \\
$\mathrm{C}$ & 1.400726 & -1.013764 & -3.70252 \\
$\mathrm{C}$ & 2.069347 & -2.329366 & -3.333485 \\
$\mathrm{C}$ & 2.718164 & -2.254729 & -1.959303 \\
$\mathrm{C}$ & 1.715373 & -1.814877 & -0.904354 \\
$\mathrm{H}$ & 0.905778 & -2.562884 & -0.821438 \\
$\mathrm{H}$ & 2.179941 & -1.781862 & 0.092864 \\
$\mathrm{H}$ & 3.153437 & -3.226791 & -1.681064 \\
$\mathrm{H}$ & 3.55996 & -1.538309 & -1.984796 \\
$\mathrm{H}$ & 2.8074 & -2.612454 & -4.099856 \\
$\mathrm{H}$ & 1.310939 & -3.132065 & -3.331248 \\
\hline & & & \\
& &
\end{tabular}




\begin{tabular}{|c|c|c|c|}
\hline $\mathrm{H}$ & 0.892622 & -1.093296 & -4.676105 \\
\hline $\mathrm{H}$ & 2.172579 & -0.231518 & -3.826784 \\
\hline $\mathrm{H}$ & -0.411992 & -1.29796 & -2.554778 \\
\hline $\mathrm{H}$ & -0.05062 & 0.394322 & -2.929394 \\
\hline $\mathrm{H}$ & 1.914264 & 0.284246 & -1.35532 \\
\hline $\mathrm{C}$ & -0.739039 & 1.744975 & -0.585212 \\
\hline $\mathrm{C}$ & 0.301697 & 2.727254 & -1.118952 \\
\hline $\mathrm{C}$ & -0.377263 & 3.927076 & -1.767749 \\
\hline $\mathrm{C}$ & -1.324905 & 4.621856 & -0.801667 \\
\hline $\mathrm{C}$ & -2.329582 & 3.645058 & -0.210076 \\
\hline $\mathrm{C}$ & -1.638728 & 2.449441 & 0.431148 \\
\hline $\mathrm{H}$ & -1.022754 & 2.790806 & 1.283623 \\
\hline $\mathrm{H}$ & -2.384353 & 1.755083 & 0.844622 \\
\hline $\mathrm{H}$ & -2.972842 & 4.148661 & 0.527595 \\
\hline $\mathrm{H}$ & -3.008289 & 3.28035 & -1.001983 \\
\hline $\mathrm{H}$ & -1.839995 & 5.45786 & -1.299544 \\
\hline $\mathrm{H}$ & -0.73548 & 5.074884 & 0.015889 \\
\hline $\mathrm{H}$ & 0.38025 & 4.630864 & -2.146542 \\
\hline $\mathrm{H}$ & -0.939978 & 3.582829 & -2.654271 \\
\hline $\mathrm{H}$ & 0.920361 & 3.077441 & -0.273397 \\
\hline $\mathrm{H}$ & 0.98946 & 2.245796 & -1.833104 \\
\hline $\mathrm{H}$ & -1.381794 & 1.431689 & -1.428968 \\
\hline $\mathrm{Pd}$ & -1.40534 & -1.6144 & 0.459825 \\
\hline $\mathrm{C}$ & -2.988083 & -0.582292 & -0.133227 \\
\hline $\mathrm{C}$ & -3.950274 & -0.34845 & 0.858852 \\
\hline $\mathrm{C}$ & -5.203639 & 0.160949 & 0.512427 \\
\hline $\mathrm{C}$ & -5.505441 & 0.448266 & -0.818747 \\
\hline $\mathrm{C}$ & -4.548893 & 0.214359 & -1.805652 \\
\hline $\mathrm{C}$ & -3.290259 & -0.290326 & -1.467964 \\
\hline $\mathrm{H}$ & -2.555204 & -0.468622 & -2.258114 \\
\hline $\mathrm{H}$ & -4.779964 & 0.422036 & -2.854236 \\
\hline $\mathrm{H}$ & -6.486194 & 0.848052 & -1.086451 \\
\hline $\mathrm{H}$ & -5.948353 & 0.332457 & 1.2944 \\
\hline $\mathrm{H}$ & -3.732858 & -0.571622 & 1.908446 \\
\hline $\mathrm{Cl}$ & -0.997586 & -3.78949 & 1.23434 \\
\hline \multicolumn{4}{|c|}{$\begin{array}{c}\mathrm{Cl} \\
\mathrm{I} \\
\mathrm{L}-\mathrm{Pd} \\
\quad \mathrm{I} \\
\mathrm{Ph}(\mathrm{I}-\mathrm{S} 7)\end{array}$} \\
\hline Atom & $\mathrm{x}$ & $\mathrm{y}$ & $\mathrm{z}$ \\
\hline $\mathrm{C}$ & -0.767482 & 1.534679 & -0.710622 \\
\hline $\mathrm{C}$ & -1.647099 & 2.351247 & 0.234984 \\
\hline $\mathrm{C}$ & -2.404703 & 3.416637 & -0.544272 \\
\hline $\mathrm{C}$ & -1.453542 & 4.327196 & -1.307537 \\
\hline $\mathrm{C}$ & -0.506472 & 3.531909 & -2.193403 \\
\hline $\mathrm{C}$ & 0.231401 & 2.455264 & -1.406309 \\
\hline $\mathrm{H}$ & 0.913168 & 1.896134 & -2.067685 \\
\hline $\mathrm{H}$ & 0.865001 & 2.933565 & -0.638217 \\
\hline $\mathrm{H}$ & -1.079287 & 3.049427 & -3.00597 \\
\hline $\mathrm{H}$ & 0.215237 & 4.199466 & -2.68959 \\
\hline
\end{tabular}




\begin{tabular}{|c|c|c|c|}
\hline & 84 & 17 & 17 \\
\hline & -0.860552 & 4.915183 & -0.583839 \\
\hline & -3.093988 & 2.916272 & -1.248405 \\
\hline & -3.041676 & 4.002996 & 0.135584 \\
\hline & -2.347039 & 1.698959 & 0.777941 \\
\hline & -1.009329 & 2.832233 & 0.998987 \\
\hline $\mathrm{H}$ & -1.431133 & 1.099707 & -1.480253 \\
\hline $\mathrm{P}$ & -0.045579 & 0.031915 & 2305 \\
\hline & 1.042935 & -0.767319 & -1.16529 \\
\hline & 1.625081 & -2.087388 & 8373 \\
\hline & 2.558944 & -2.700319 & -1.6 \\
\hline $\mathrm{C}$ & $1.85^{\circ}$ & & \\
\hline $\mathrm{C}$ & 1.23 & 637 & \\
\hline C & 0.299253 & 581 & 2346 \\
\hline & -0.54021 & 8031 & -2.291321 \\
\hline & -0.14 & -0.074925 & \\
\hline & 0.6 & -1. & 096 \\
\hline & 2.03 & & \\
\hline & 2.5 & -3 & \\
\hline & 1.064184 & -3.6 & \\
\hline & 2.9 & -3. & \\
\hline & 3.43 & -2.0 & 399 \\
\hline & 0.79 & -2.7 & 476 \\
\hline & 2.12 & -1 & \\
\hline $\mathrm{H}$ & 18 & -0 . & \\
\hline C & 0.92 & & \\
\hline 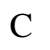 & 2.30 & & \\
\hline c & 2.811115 & 1.450431 & 2.821626 \\
\hline C & 2.003242 & 1.6 & 664 \\
\hline $\mathrm{C}$ & 0.64 & 11 & \\
\hline $\mathrm{C}$ & .12 & & 01 \\
\hline $\mathrm{H}$ & -0.93 & & \\
\hline I & -0.008506 & 1.5 & 17156 \\
\hline H & 2.438429 & 2.04 & 4.858601 \\
\hline $\mathrm{H}$ & 3.881385 & 1.666226 & 2.879153 \\
\hline C & 3.30 & & 839 \\
\hline C & 4.16 & -0. & \\
\hline $\mathrm{C}$ & 5.15 & -0.4 & 543 \\
\hline $\mathrm{C}$ & 5.310397 & 0.45 & -1.429395 \\
\hline $\mathrm{C}$ & 4.48598 & 1.57854 & -1.451577 \\
\hline $\mathrm{C}$ & 3.502005 & 1.745498 & -0.478092 \\
\hline & 2.88 & 2.64 & -0.483742 \\
\hline & 4.61 & 2.3 & 404 \\
\hline $\mathrm{H}$ & 6.082407 & 0.323456 & -2.191132 \\
\hline $\mathrm{H}$ & 5.808988 & -1.366127 & -0.378596 \\
\hline $\mathrm{H}$ & 4.05138 & -1.066946 & 1.348608 \\
\hline 10 & -1.518644 & -1.464359 & 0.854608 \\
\hline 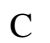 & -3.077097 & -0.675355 & -0.11344 \\
\hline $\mathrm{C}$ & -3.320145 & -0.645925 & -1.493758 \\
\hline $\mathrm{C}$ & -4.574613 & -0.281154 & -1.989466 \\
\hline $\mathrm{C}$ & -5.602765 & 0.07538 & -1.117995 \\
\hline
\end{tabular}




\begin{tabular}{cccc}
$\mathrm{C}$ & -5.372315 & 0.059545 & 0.25716 \\
$\mathrm{C}$ & -4.118098 & -0.302714 & 0.753987 \\
$\mathrm{H}$ & -3.955926 & -0.29061 & 1.838758 \\
$\mathrm{H}$ & -6.169042 & 0.33995 & 0.951778 \\
$\mathrm{H}$ & -6.58048 & 0.367141 & -1.508862 \\
$\mathrm{H}$ & -4.747728 & -0.280094 & -3.069463 \\
$\mathrm{H}$ & -2.534484 & -0.923017 & -2.202855 \\
$\mathrm{Cl}$ & -0.158268 & -2.747468 & 2.312726 \\
\hline
\end{tabular}




\section{References}

${ }^{1}$ Wang, Y.; Gu, M. The Concept of Spectral Accuracy for MS. Anal. Chem. 2010, 82, 7055-7062.

${ }^{2}$ Yu, Z.; Pan, Y.; Wang, Z.; Wang, J.; Lin, Q. Genetically Encoded Cyclopropene Directs Rapid, PhotoclickChemistry-Mediated Protein Labeling in Mammalian Cells. Angew. Chem. Int. Ed. 2012, 51, 10600-10604.

${ }^{3}$ DeAngelis, A. J.; Gildner, P. G.; Chow, R.; Colacot, T. J. Generating Active "L-Pd(0)" via Neutral or Cationic $\pi$ Allylpalladium Complexes Featuring Biaryl/Bipyrazolylphosphines: Synthetic, Mechanistic, and Structure-Activity Studies in Challenging Cross-Coupling Reactions. J. Org. Chem. 2015, 80, 6794-6813.

${ }^{4}$ Jalil, A. A.; Kurono, N.; Tokuda, M. Facile Synthesis of Ethyl 2-Arylpropenoates by Cross-Coupling Reaction Using Electrogenerated Highly Reactive Zinc. Tetrahedron 2002, 58, 7477-7484.

${ }^{5}$ Sandoval, B. A.; Meichan, A. J.; Hyster, T. K. Enantioselective Hydrogen Atom Transfer: Discovery of Catalytic Promiscuity in Flavin-Dependent 'Ene'-Reductases. J. Am. Chem. Soc. 2017, 139, 11313-11316.

${ }^{6}$ Barluenga, J.; Tomás-Gamasa, M.; Aznar, F.; Valdés, C. Synthesis of 2-Arylacrylates from Pyruvate by Tosylhydrazide-Promoted Pd-Catalyzed Coupling with Aryl Halides. Chem. Eur. J. 2010, 16, 12801-12803.

${ }^{7}$ Hu, X.-H.; Zhang, J.; Yang, X.-F.; Xu, Y.-H.; Loh, T.-P. Stereo- and Chemoselective Cross-Coupling between Two Electron-Deficient Acrylates: An Efficient Route to (Z,E)-Muconate Derivatives. J. Am. Chem. Soc. 2015, 137, 3169-3172.

${ }^{8}$ Poh, J.-S.; Tran, D. N.; Battilocchio, C.; Hawkins, J. M.; Ley, S. V. A Versatile Room-Temperature Route to Diand Trisubstituted Allenes Using Flow-Generated Diazo Compounds. Angew. Chem. Int. Ed. 2015, 54, 7920-7923.

${ }^{9}$ Chua, C. K.; Pumera, M. The Reduction of Graphene Oxide with Hydrazine: Elucidating its Reductive Capability Based on a Reaction-Model Approach. Chem. Commun. 2016, 52, 72-75.

10 Mendoza-Espinosa, D.; Rendón-Nava, D.; Alvarez-Hernández, A.; Angeles-Beltrán, D.; Negrón-Silva, G. E.; Suárez-Castillo, O. R. Visible-Light-Promoted AuI to AuIII Oxidation in Triazol-5-ylidene Complexes. Chem. Asian J. 2017, 12, 203-207.

${ }^{11}$ Rullière, P.; Benoit, G.; Allouche, E. M. D.; Charette, A. B. Safe and Facile Access to Nonstabilized Diazoalkanes Using Continuous Flow Technology. Angew. Chem. Int. Ed. 2018, 57, 5777-5782.

${ }^{12}$ Campbell, J. R.; Pross, A.; Sternhel, S. Preparation and Chemistry of Some 1-Iodo-1-Phenylpropenes. Aust. J. Chem. 1971, 24, 1425-1436.

${ }^{13}$ McHardy, S. F.; Liras, S.; Heck, S. D. 3-Azabicyclo[3.1.0]hexane Derivatives as Opioid Receptor Antagonists. WO Patent 2003/035622 A1, 2003.

${ }^{14}$ Dota, K.; Sugita, Y.; Akioka, Y.; Maehata, N.; Arimori, S. Preparation of Tetrazolinone Compounds as Pest Control Agents. WO. Patent 2018/097318 A1, May 31, 2018.

${ }^{15}$ Xu, L.; Li, B.-J.; Wu, Z.-H.; Lu, X.-Y.; Guan, B.-T.; Wang, B.-Q.; Zhao, K.-Q.; Shi, Z.-J. Nickel-Catalyzed Efficient and Practical Suzuki-Miyaura Coupling of Alkenyl and Aryl Carbamates with Aryl Boroxines. Org. Lett. 2010, 12, 884-887.

16 Tan, H.; Houpis, I.; Liu, R.; Wang, Y.; Chen, Z. Olefin Preparation via Palladium-Catalyzed Oxidative DeAzotative and De-Sulfitative Internal Cross-Coupling of Sulfonylhydrazones. Org. Lett. 2015, 17, 3548-3551.

${ }^{17}$ Lei, C.; Yip, Y. J.; Zhou, J. S. Nickel-Catalyzed Direct Synthesis of Aryl Olefins from Ketones and Organoboron Reagents under Neutral Conditions. J. Am. Chem. Soc. 2017, 139, 6086-6089.

18 Tang, J.; Hackenberger, D.; Goossen, L. J. Branched Arylalkenes from Cinnamates: Selectivity Inversion in Heck Reactions by Carboxylates as Deciduous Directing Groups. Angew. Chem. Int. Ed. 2016, 55, 11296-11299.

${ }^{19}$ Li, R.; Wang, S. R.; Lu, W. FeCl3-Catalyzed Alkenylation of Simple Arenes with Aryl-Substituted Alkynes. Org. Lett. 2007, 9, 2219-2222. 
${ }^{20}$ Zou, Y.; Qin, L.; Ren, X.; Lu, Y.; Li, Y.; Zhou, J. Selective Arylation and Vinylation at the $\alpha$ Position of Vinylarenes. Chem. Eur. J. 2013, 19, 3504-3511.

${ }^{21}$ Frisch, M. J.; Trucks, G. W.; Schlegel, H. B.; Scuseria, G. E.; Robb, M. A.; Cheeseman, J. R.; Scalmani, G.; Barone, V.; Mennucci, B.; Petersson, G. A.; Nakatsuji, H.; Caricato, M.; Li, X.; Hratchian, H. P.; Izmaylov, A. F.; Bloino, J.; Zheng, G.; Sonnenberg, J. L.; Hada, M.; Ehara, M.; Toyota, K.; Fukuda, R.; Hasegawa, J.; Ishida, M.; Nakajima, T.; Honda, Y.; Kitao, O.; Nakai, H.; Vreven, T.; Montgomery Jr., J. A.; Peralta, J. E.; Ogliaro, F.; Bearpark, M. J.; Heyd, J.; Brothers, E. N.; Kudin, K. N.; Staroverov, V. N.; Kobayashi, R.; Normand, J.; Raghavachari, K.; Rendell, A. P.; Burant, J. C.; Iyengar, S. S.; Tomasi, J.; Cossi, M.; Rega, N.; Millam, N. J.; Klene, M.; Knox, J. E.; Cross, J. B.; Bakken, V.; Adamo, C.; Jaramillo, J.; Gomperts, R.; Stratmann, R. E.; Yazyev, O.; Austin, A. J.; Cammi, R.; Pomelli, C.; Ochterski, J. W.; Martin, R. L.; Morokuma, K.; Zakrzewski, V. G.; Voth, G. A.; Salvador, P.; Dannenberg, J. J.; Dapprich, S.; Daniels, A. D.; Farkas, Ö.; Foresman, J. B.; Ortiz, J. V.; Cioslowski, J.; Fox, D. J. Gaussian 09, Rev. c.0.1; Gaussian, Inc.: Wallingford, CT, USA, 2009.

22 a) Zhao, Y.; Truhlar, D. G. A New Local Density Functional for Main-Group Thermochemistry, Transition Metal Bonding, Thermochemical Kinetics, and Noncovalent Interactions. J. Chem. Phys. 2006, 125, 194101-1-194101-18; b) Zhao, Y.; Truhlar, D. G. The M06 Suite of Density Functionals for Main Group Thermochemistry, Thermochemical Kinetics, Noncovalent Interactions, Excited States, and Transition Elements: Two New Functionals and Systematic Testing of Four M06-Class Functionals and 12 Other Functionals. Theor. Chem. Acc. 2008, 120, 215-241.

${ }^{23}$ Weigend, F.; Ahlrichs, R. Balanced Basis Sets of Split Valence, Triple Zeta Valence and Quadruple Zeta Valence Quality for H to Rn: Design and Assesment of Accuracy. PCCP 2005, 7, 3297-3305.

${ }^{24}$ Andrae, D.; Haussermann, U.; Dolg, M.; Stoll, H.; Preuss, H. Energy-Adjusted Ab Initio Pseudopotentials for the 2nd and 3rd Row Transition-Elements. Theor. Chim. Acta 1990, 77, 123-141.

25 a) Miertus, S.; Scrocco, E.; Tomasi, J. Electrostatic Interaction of a Solute with a Continuum - a Direct Utilization of Ab Initio Molecular Potentials for the Prevision of Solvent Effects. Chem. Phys. 1981, 55, 117-129; b) Miertus, S.; Tomasi, J. Approximate Evaluations of the Electrostatic Free-Energy and Internal Energy Changes in Solution Processes. Chem. Phys. 1982, 65, 239-245; c) Barone, V.; Cossi, M.; Tomasi, J. Geometry Optimization of Molecular Structures in Solution by the Polarizable Continuum Model. J. Comput. Chem. 1998, 19, 404-417; d) Cossi, M.; Scalmani, G.; Rega, N.; Barone, V. New Developments in the Polarizable Continuum Model for Quantum Mechanical and Classical Calculations on Molecules in Solution. J. Chem. Phys. 2002, 117, 43-54.

${ }^{26}$ Peng, C.; Yan, G.; Wang, Y.; Jiang, Y.; Zhang, Y.; Wang, J. Palladium-Catalyzed Coupling Reaction of $\alpha-$ Diazocarbonyl Compounds with Aromatic Boronic Acids or Halides. Synthesis 2010, 2010, 4154-4168.

${ }^{27}$ Kozuch, S.; Shaik, S. How to Conceptualize Catalytic Cycles? The Energetic Span Model. Acc. Chem. Res. 2011, 44, 101-110. 